\title{
ESTUDO HIDROGEOLÓGICO DAS ZONAS NĀO SATURADA E SATURADA DA FORMAÇÃO ADAMANTINA, EM PRESIDENTE PRUDENTE, ESTADO DE SÃO PAULO
}

Manoel Carlos Toledo Franco de Godoy

Orientadora: Profa. Dra. Annkarin Aurélia Kimmelmann e Silva

TESE DE DOUTORAMENTO

Programa de Pós-Graduação em Recursos Minerais e Hidrogeologia 


\section{UNIVERSIDADE DE SÃO PAULO INSTITUTO DE GEOCIÊNCIAS}

\section{ESTUDO HIDROGEOLÓGICO DAS ZONAS NÃO SATURADA E SATURADA DA FORMAÇÃO ADAMANTINA, EM PRESIDENTE PRUDENTE, ESTADO DE SÃO PAULO}

MANOEL CARLOS TOLEDO FRANCO DE GODOY

Orientadora: Prof - ${ }^{\text {a. }}{ }^{\text {a. }}$ Annkarin Aurélia Kimmelamann e Silva

TESE DE DOUTORAMENTO

COMISSÃO JULGADORA

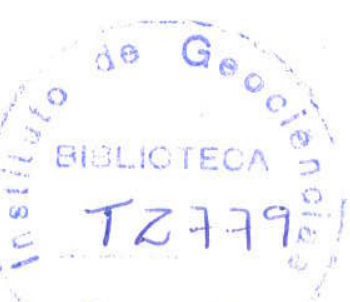

Nome

Presidente: $\quad$ Prof $^{\mathrm{a}} \mathrm{Dr}^{\mathrm{a}}$ Annkarin Aurélia K. e Silva

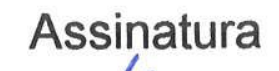

Examinadores: Prof. Dr. Luiz Roberto Cottas

Prof ${ }^{\text {a. }}$ Dr. Mária Szikszay

Prof. Dr. Osmar Sinelli

Prof. Dr. Ricardo César Aoki Hirata

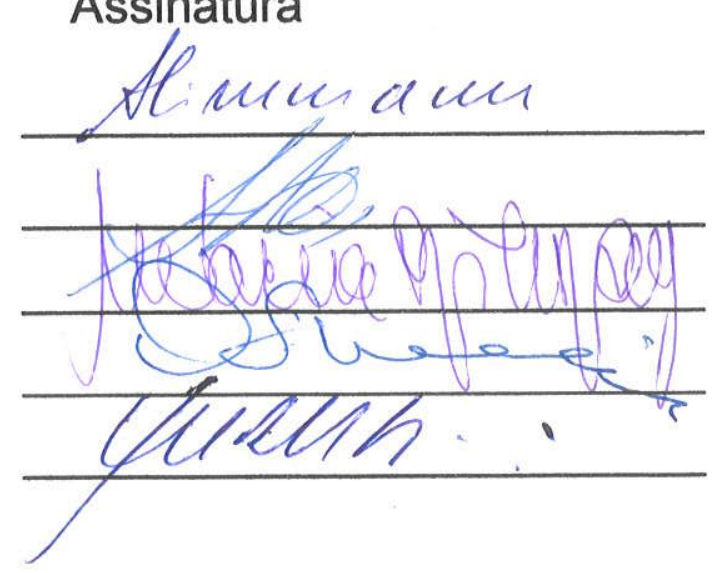

SÃO PAULO

1999 


\section{ESTUDO HIDROGEOLÓGICO DAS ZONAS NĀO SATURADA E SATURADA DA FORMAÇĀO ADAMANTINA, EM PRESIDENTE PRUDENTE, ESTADO DE SÃO PAULO}

Manoel Carlos Toledo Franco de Godoy

Orientadora: Profa. Dra. Annkarin Aurélia Kimmelmann e Silva

\section{TESE DE DOUTORAMENTO}

Programa de Fós-Graduação em Recursos Minerais e Hidrogeologia

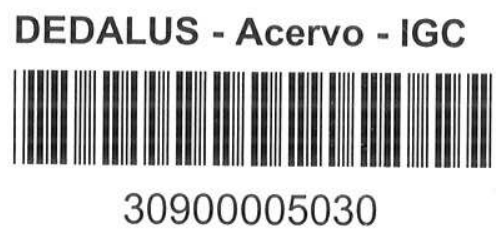


Ao meu pai, João (in memorian).

À minha mãe, Vera.

À minha esposa, Nelsi.

Aos meus filhos, Marina e Leonardo. 
A elaboração desta tese foi possível graças à colaboração de pessoas e instituiçōes, a quem dirijo meus agradecimentos.

À Fundação de Amparo à Pesquisa do Estado de São Paulo - FAPESP, pelo apoio financeiro ao projeto da pesquisa, sem o qual esta não seria executada.

À Faculdade de Ciências e Tecnologia, da Universidade Estadual Paulista - UNESP/ Campus de Presidente Prudente, na pessoa do ex-diretor, Prof. Dr. Alvanir de Figueiredo e do atual diretor, Prof. Dr. Messias Meneguette Júnior, pela cessão de uma área do campus para a execução da pesquisa e pela garantia do serviço prestado à pesquisa pelo Laboratório de Sedimentologia desta unidade da UNESP.

Ao Centro de Pesquisa de Águas Subterrâneas - CEPAS, do Instituto de Geociências da Universidade de São Paulo - ICUSP, pela sua colaboração com a pesquisa através de recursos técnicos fornecidos para o trabalho de campo da pesquisa e através do serviço do seu Laboratório de Hidroquímica.

À Companhia de Saneamento Básico do Estado de São Paulo - SABESP, Unidade de Négócios do Baixo Paranapanema, na pessoa do Engo. João Francisco Herzmann Netto, Gerente de Controle Sanitário, pela sua colaboração na execução de análises químicas de água.

Ao Prof. Dr. Osny de Oliveira Bacchi, do Centro de Pesquisas Nucleares da Agricultura - CENA e ao Prof. Dr. Klaus Reichardt, da Escola Superior de Agricultura "Luiz de Queiroz" - ESALQ, pela atenção que me concederam para a soluçāo de questões relacionadas à Física de Solos.

Aos docentes da Faculdade de Ciências e Tecnologia, da Universidade Estadual Paulista - UNESP/Campus de Presidente Prudente: Prof. D. Homero Marques Comes, Prof. Ms. Roberto Bernardo de Azevedo, Prof $D$ Silvio Rainho Teixeira Prof. D José Tadeu Garcia Tomaselli, Prof. D Angel Vilche Peña, do Departamento de Fisica, Química e Biologia, Prof. D José Martin Suarez, Prof. $D$. Octavio Freire, Prof . $D^{a}$. Wolmar Apparecida Carvalho, do Departamento de Geografia e Prof. D Sérgio Minoru Oikawa, do Departamento de 
Matemática e Estatistica, pela sua ajuda com relação a questöes específicas aos campos de conhecimento de cada um deles.

Aos funcionários da Faculdade de Ciências e Tecnologia - UNESP/ Campus de Presidente Prudente: Maria Cristina Perusi, Pedro Gardim e Marilza De Stéfani Cardoso, pela sua particular consideração à minha pessoa e pela dedicação profissional com que prestaram sua colaboração.

Aos alunos e ex-alunos da Faculdade de Ciências e Tecnologia - UNESP/ Campus de Presidente Prudente: Darsio Cândido Batista, Adão Robson Elias, do Curso de Bacharelado em Geografia, pela sua ajuda em trabalhos de campo e ítalo Tsuchyia, Frederic Gomes da Silva e Hostílio Maia de Paula Neto, do Curso de Engenharia Cartográfica, pela sua importante ajuda no serviço de campo e no cálculo de planilhas do levantamento topográfico.

À Prof ${ }^{\prime} D^{a}$. Annkarin Aurelia Kimmelmann e Silva, minha orientadora no curso de pós-graduação, pela orientação, acompanhamento e apoio para a elaboração desta tese. 


\section{SUMÁRIO}

1. INTRODUÇÃO.

3. REVISÃO BIBLIOGRÁFICA.

3.1. PESQUISAS EM HIDROGEOQUÍMICA ATRAVÉS DE EQUIPAMENTOS FIXOS. 3

3.2. ASPECTOS DE HIDRODINÂMICA EM MEIOS POROSOS ...........................

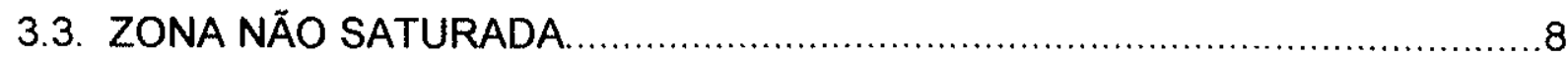

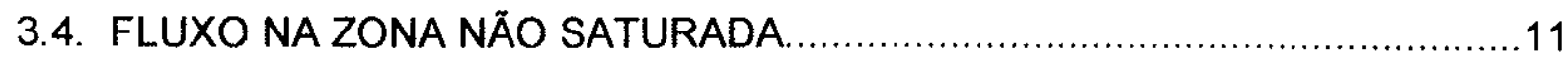

4. MATERIAIS E MÉTODOS

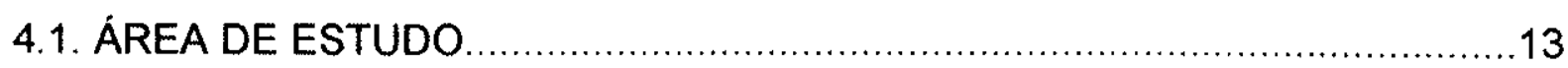

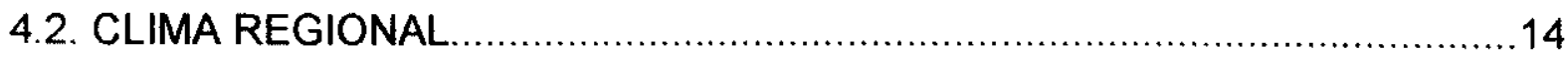

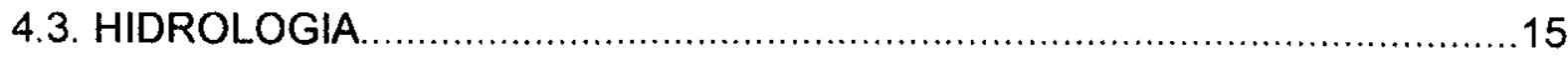

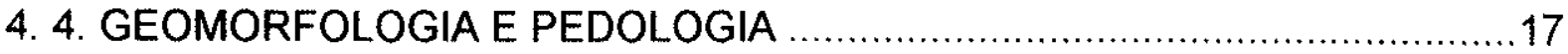

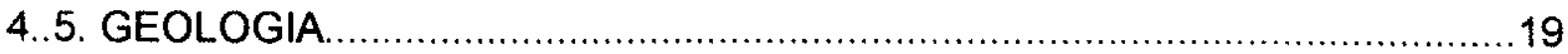

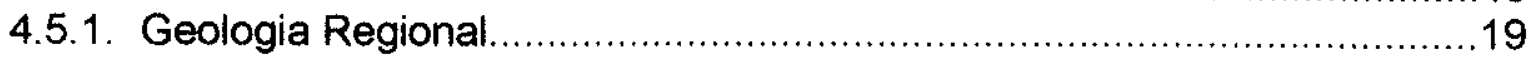

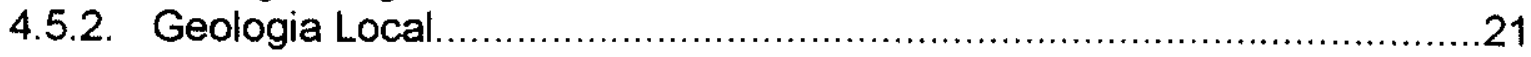

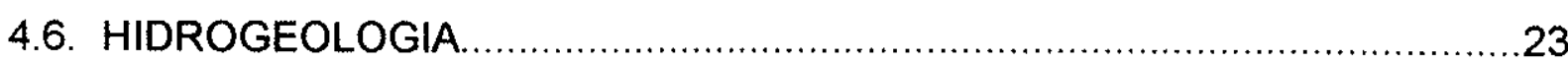

4.7. ESCOLHA DA ÁREA PARA A INSTALAÇÃO DA ESTAÇÃO PILOTO .........28

4.8. CONSTITUIÇÃO DA ESTAÇÃO PILOTO

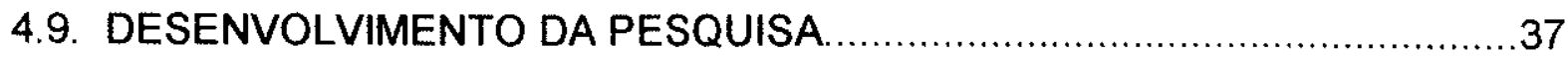

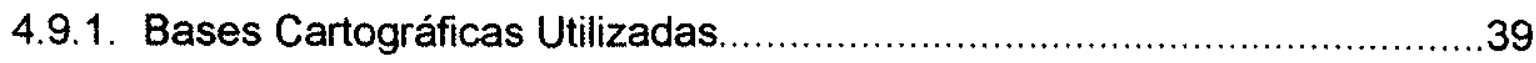

4.9.2. Escolha do Local de Instalação dos Equipamentos...............................39

4.9.3. Levantamento Geológico e Pedológico de Detalhe ..................................41

4.9.3.1. Amostragem de rochas e de solos.............................................

4.9.3.2. Zoneamento do substrato rochoso na zona não saturada ................44

4.9.3.3 Caracterização pedológica do solo...............................................45

4.9.4. Informações sobre a Hidrodinâmica da Zona Não Saturada..................46

4.9.4.1. Dados da estação meteorológica.......................................................46 
4.9.4.2. Medidas de potencial de água no solo: tensiômetros. 48

4.9.4.3. Medidas de potencial de água no solo - blocos de gesso. 51

4.9.4.4. Ensaio de infiltração.

4.9.4.5. Determinações de laboratório - correlação

umidade $x$ potencial mátrico e curva de retenção .58

4.9.4.6. Medida do escoamento superficial. .59

4.9.4.7. Classificação do meio poroso relacionada à condutividade hidráulica. 62

4.9.5. Informações sobre a Hidrodinâmica da Zona Saturada. 62

4. 9.5.1. Dados climatológicos para a recarga. .63

4.9.5.2. Medições do nível freático 64

4.9.6. Hidrogeoquímica. .67

4.9.6.1. Coleta de amostras de água. .69

A - Coleta da zona não saturada 69

B - Coleta do aqüífero livre. .71

C- Coleta junto às surgências. .73

D - Coleta de água de chuva .73

4.6.9.2. Análises químicas.

5. RESULTADOS E DISCUSSÃO .76

5.1. DADOS CLIMATOLÓGICOS. .76

5.2. RESULTADOS REFERENTES À LITOLOGIA E À PEDOLOGIA .78

5.3. PROPRIEDADE DO SOLO RELACIONADAS À ÁGUA. 88

5.3.1. Capacidade de Retenção de Água .88

5.3.2. Resultados do Ensaio de Infiltração.. 88

5.3.3. Determinação da Condutividade Hidráulica .96

5.4. RESULTADOS REFERENTES A DADOS DE MONITORAMENTO. .96

5.4.1. Resultados Referentes à Variação do Potencial de Água no Solo .96

A - Resultados dos tensiômetros. .97

B - Resultados dos blocos de gesso. 104

5.4. 2. Comportamento do Nivel Freático. 105

5.4.3. Resultados Referentes ao Escoamento Superficial 114

5.5. ZONEAMENTO REFERENTE À HIDRODINÂMICA 117

5.6. RESULTADOS DE ANÁLISES QUIMICAS 


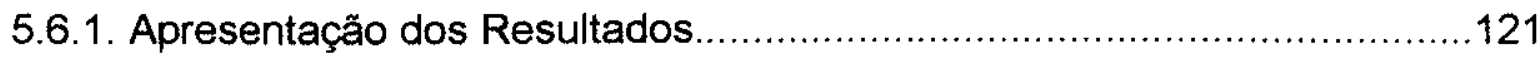

5.6.2. Alteração no Projeto de Monitoramento Hidrogeoquimico.....................122

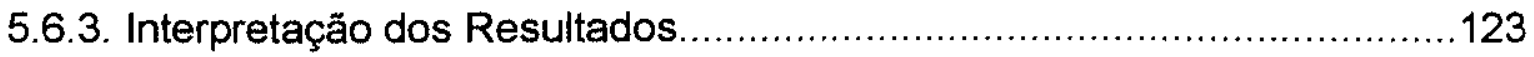

5 6.3.1. Resultados de análise estatística.............................................123

5.6.3.2. Resultados referentes à zona não saturada................................126

5.6.3.3. Resultados das análises referentes ao aqüífero freático ................128

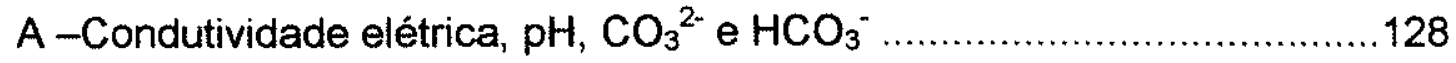

B - Resultados referentes a possíveis contaminantes ...........................132

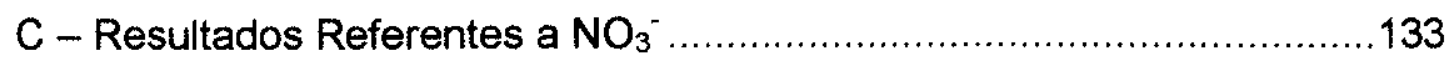

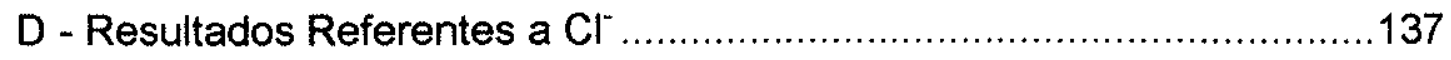

E - A Utilização dos íons $\mathrm{Cl}^{-}, \mathrm{Na}^{+}$e $\mathrm{NO}_{3}{ }^{-}$na análise da recarga do aqüífero livre.

F - Resultados referentes aos teores de $\mathrm{Na}^{+}$na água do poço tubular.

$\mathrm{G}-\mathrm{SO}_{4}{ }^{2-}$ - Interpretaçōes referentes ao rejeito de laboratório...................141

5.6.3.4. Resultados referentes à água da chuva e do açude......................144

5.6. Zoneamento Hidrogeoquímico da Àrea Estudada...............................144

6.CONCLUSÕES

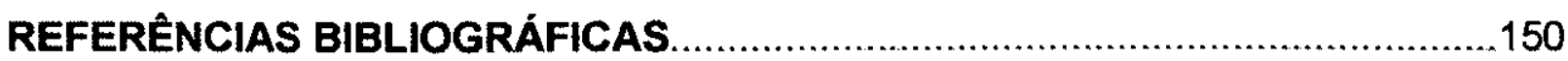




\section{LISTA DE QUADROS}

1 Arcabouço dos procedimentos adotados na pesquisa................................38

2 Investigação preliminar para escolha do local de instalação dos equipamentos............................................................40

3 Levantamentos geológico e pedológico de detalhe.......................................41

4 Aspectos metodológicos da hidrodinâmica da zona não saturada................47

5 Aspectos metodológicos da hidrodinâmica da zona saturada........................63

6 Propriedades e recursos técnicos relacionados à hidroquímica e utilizados

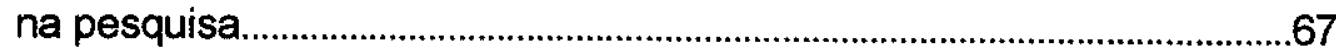

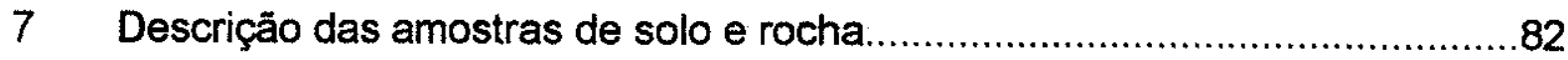

8 Características morfológicas do solo encontrado na trincheira T1 .................79

9 Características morfológicas do solo encontrado na trincheira T3.................81

10 Identificação dos resultados selecionados para a aplicação

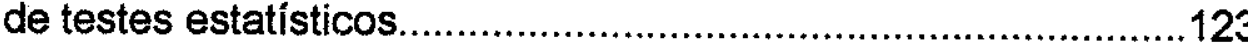




\section{LISTA DE TABELAS}

1 Resumo dos registros de temperatura e precipitação em

Presidente Prudente de 1969 a 1995.

2 Balanço hídrico seriado - Presidente Prudente - julho/96 a

julho/98.

3 Resultados de análise granulométrica e grau de cimentação -

amostras de solo e rocha.

4 Análise granulométrica e índices físicos do solo encontrado

na trincheira $T 1$.

5 Análise química do solo encontrado na trincheira T1

6 Resultados de análise do solo por Ataque Sulfúrico - Trincheira 1

7 Retenção de água no solo - Trincheira T1

8 Ensaio de infiltração - estimativa de permeabilidade - $1^{2}$ etapa. .90

9 Ensaio de infiltração - estimativa da permeabilidade $-2^{2}$ etapa. .91

10 Ensaio de infiltração - Cálculo de umidade por massa 92

11 Ensaio de infiltração - Cálculo de umidade por volume. .93

12 Ensaio de infiltração - Cálculo de umidade por volume amostras indeformadas 94

13 Potencial do solo - tensiômetros - ano de 1996. .98

14 Potencial do solo - tensiômetros - ano de 1997

15 Potencial do solo - tensiômetros - ano de 1998. 100

16 Variação da umidade do solo na estação piloto junho de 1997 102

17 Variação da umidade no solo da estação piloto outubro de 1997. 103

18 Potencial do solo - blocos de gesso. 104

19 Variação do nível do aqüifero livre. 106

20 Variação da profundidade do topo aqüifero livre - 1996

21 Variação da profundidade do topo aqǘfero livre - 1997 108

22 Variação da profundidade do topo aqüifero livre -1998. 109

23 Medidas de escoamento superficial - 1997. 
24 Medidas de escoamento superficial - 1998.

25 Números de medidas utilizados no teste estatístico referente aos dados de análises químicas

26 Resultados das anátise química referente a amostras dos extratores de cápsula porosa. 126

27 Teor de metais de extrato de solo e rocha. 127

28 Valores de medidas de condutividade elétrica (200us). 129

29 Resultados de determinação do $\mathrm{Ph}$ in loco. 130

30 Resultados de análise química da água $-\mathrm{CO}_{3}{ }^{2-}$ e $\mathrm{HCO}_{3}{ }^{-}$ 131

31 Estimativa da quantidade de $\mathrm{NO}_{3}{ }^{-}, \mathrm{Cl}^{-}$e $\mathrm{Na}^{+}$introduzidos no solo pelo vazamento de coletor de água residuária.

32 Resultados de análises química de água $-\mathrm{NO}_{3}^{-}(\mathrm{mg} / \mathrm{L})$. .134

33 Resultados de análise química da água - $\mathrm{Cl}^{-}(\mathrm{mg} / \mathrm{L})$. 135

34 Resultados de análise química da água - $\mathrm{Na}^{+}(\mathrm{mg} / \mathrm{L})$. 136

34 Variação dos teores de $\mathrm{Na}^{+}, \mathrm{Cl}^{-}, \mathrm{F}^{-}$e $\mathrm{NO}_{3}{ }^{-}$- poço $\mathrm{PMO}_{2}$ .138

36 Resultados de análise química - íon $\mathrm{SO}_{4}{ }^{2-}(\mathrm{mg} / \mathrm{L})$. 142 


\section{LISTA DE FIGURAS}

1 Estação de observação na Planície Alsaciana -

plano de instrumentação.......................................................... 6

2 Estação de observação na Planície Alsaciana - equipamento básico de

cada estação.

3 Mapa de localização da área de estudo e

principais vias de comunicação rodoviária.

4 Localização da área da pesquisa em relação à rede hidrográfica e

ao território municipal de Presidente Prudente ..............................16

5 Esboço geológico da Bacia Sedimentar do Paraná

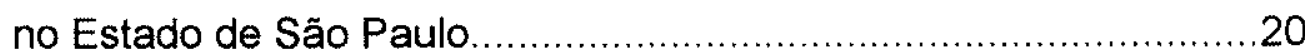

6 Distribuição das unidades do Grupo Bauru (Ks)

no Estado de São Paulo

7 Perfil geológico do poço tubular instalado no Campus

da FCT/UNESP

8 Localização da área da pesquisa em relação ao Campus

da FCT/UNESP

9 Planta da Estação Piloto: localização dos tensiômetros,

extratores de cápsula porosa e blocos de gesso ..........................36

10 Exemplo de perfil de varredura do método GPR ….................................40

11 Planta planialtimétrica da área pesquisada ............................................43

12 Esquema de instalação de um tensiômetro

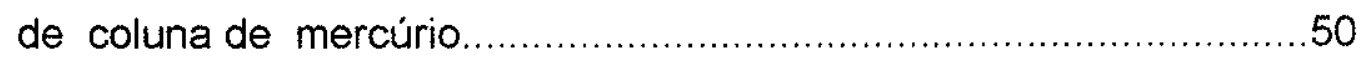

13 Ábaco utilizado para conversão de leituras do medidor Soilmoisture em valores de potencial mátrico.

14 Esquema de duas técnicas adotadas para o ensaio de infiltração

de água no solo.

15 Esquema de canteiro de deflúvio superficial..........................................59

16 Perfil esquemático de poço de monitoramento..........................................65 
17 Esquema de extrator de cápsula porosa

18 Balanço hídrico - método de Thorntwaite - 07/96 a 07/98.

19 Planta da área delimitada por levantamento topográfico

no campo.

20 Curva de retenção de água - trincheira T1

21 Ensaio de infiltração - gráfico infiltração $x$ tempo.

22 Gráfico umidade $x$ profundidade em tempos diferentes, durante e após a inundação. .95

23 Potencial do solo - tensiômetros .98

24 Potencial do solo - tensiômetros - ano de 1997. .99

25 Potencial do solo - tensiômetros - ano de 1998 100

26 Variação da profundidade do topo do aqüifero livre - 1996 107

27 Variação da profundidade do topo do aqüífero livre - 1997. 108

28 Variação da profundidade do topo do aqüífero livre - 1998. 109

29 Esboço de mapa potenciométrico. 112

30 Gráfico de relação chuva $x$ deflúvio superficial -1997. 115

31 Gráfico de relação chuva $x$ deflúvio superficial -1998 . 116

32 Zoneamento do meio ambiente na área da pesquisa com base em características hidrodinâmicas, hidrogeoquímicas e de interferência antrópica

33 Perfil da encosta Oeste da área pesquisada - Hidrogeologia 120 Variação de teores de $\mathrm{Na}^{+}, \mathrm{Cl}^{-}, \mathrm{F}^{-}$e $\mathrm{NO}_{3}^{-}$- poço $\mathrm{PMO} 2$ 


\section{LISTA DE FOTOS}

1 Detalhe de perfil da zona não saturada - próximo ao

Campus da FCT/UNESP .24

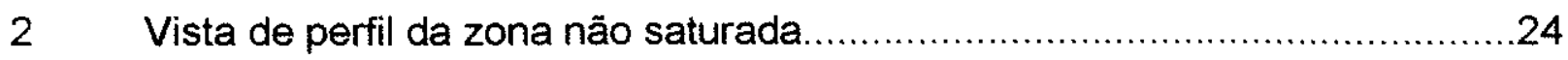

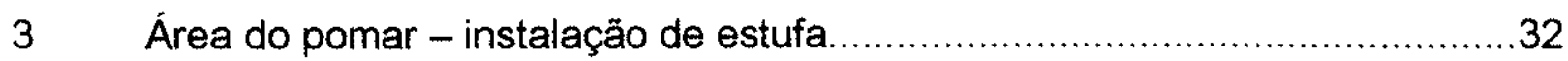

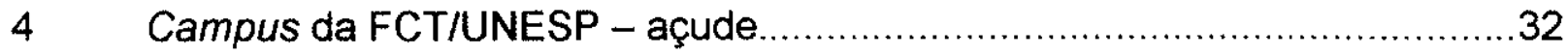

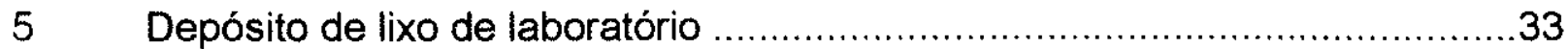

6 Detaihe de vazamento de coletor de água residuária..................................33

$7 \quad$ Bateria de tensiômetros e extratores de cápsula porosa ............................52

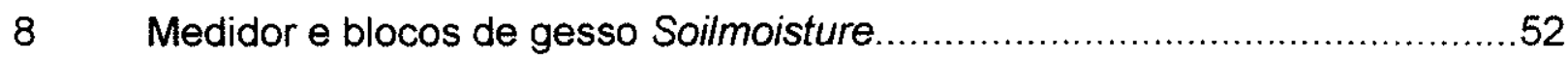

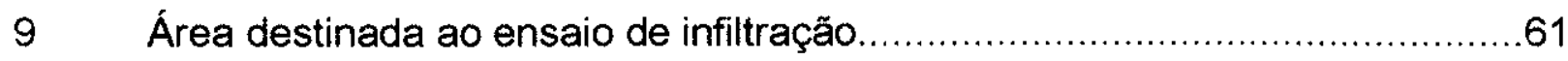

10 Canteiro de deflúvio superficial em instalação...........................................61

11 Detalhe de instalação de poço de monitoramento .........................................66

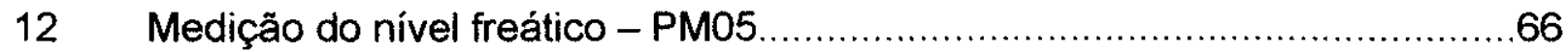

13 Extração de água do solo - bombas de vácuo Pfeiffer.................................72

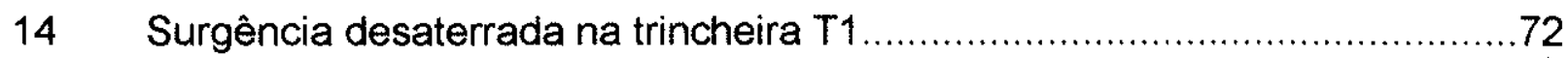

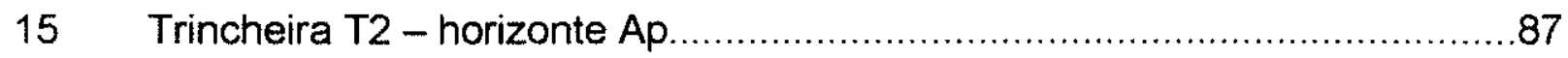

16 Trincheira T3 - perfil de solo, com detalhe de ressudação d'água...............87 


\section{RESUMO}

A área estudada está localizada na porção oeste do Estado de São Paulo, em terreno formado por depósitos sedimentares da Formação Adamantina, Grupo Bauru, Cretáceo Superior.

Os objetivos do estudo foram o monitoramento, através de uma estação piloto, do comportamento hidrodinâmico e hidrogeoquímico das zonas não saturada e saturada.

Os resultados demonstraram que diversas variáveis devem ser consideradas nos processos estudados, inclusive as de natureza antrópica. A pesquisa mostrou também uma resposta de tempo muito curto do nível freático aos eventos de precipitação pluvial, assim como a heterogeneidade espacial do ponto de vista hidrogeoquímico, em razão das diferentes combinações de variáveis de natureza litológica, estrutural, pedológica, hidrológica, da vegetação e de formas de ocupação e uso do terreno.

\section{ABSTRACT}

The area under study is located in the western portion of the State of Säo Paulo and it is composed by cretaceous sedimentary deposits of the Adamantina Formation, Bauru Group.

The objective of the study was monitoring, by means of a pilot station, the hydrodynamical and hydrogeochemical behavior of the unsaturated and saturated zones of these deposits.

The results showed that several variables must be considered as involved in the processes under survey, including the anthropic ones.

The research also showed a short time response of the water table level to rain events and a spatial hydrogeochemical heterogeneity, because of different ways of combining variables which are involved, such as lythological and structural features, the behavior of the soils, as well the vegetation and the forms of land use. 


\section{INTRODUÇÃO}

A zona não saturada, do ponto de vista hidrodinâmico e do comportamento geoquímico das águas entre 0 acontecimento da chuva e a infiltração definitiva no aqüifero freático, vem sendo pesquisada mais intensamente pelos hidrogeólogos nas últimas duas décadas, com isto valorizando a função de estações-piloto, tanto em caráter de observação, como para fins experimentais. O presente estudo mostra a instalação de uma tal estação e um trabalho de monitoramento associado a ela, no Município de Presidente Prudente, no Estado de São Paulo, em domínios dos depósitos sedimentares do Grupo Bauru, especificamente em área de afloramento da Formação Adamantina, muito vulnerável à crescente contaminação por resíduos líqüidos e sólidos, industriais e domiciliares.

A partir desta estação, foi estudado o comportamento hidrodinâmico e hidrogeoquímico da zona não saturada e da zona saturada em região de clima subtropical úmido, com solos sujeitos a reações biogeoquímicas intensas. Além do monitoramento do "background" durante um ano hidrológico, foi monitorada a composição química da água no solo e no subsolo, após ter acontecido a contaminação pelo rompimento de um coletor de água residuária, cuja existência era até entäo desconhecida.

Neste estudo, foram analisados em conjunto fatores do ambientes de natureza diversa, que interferem na hidrodinâmica e a hidrogeoquímica, para serem estabelecidas correlações entre eles e o comportamento da água subterrênea. 


\section{OBJETIVOS}

Os objetivos deste estudo são:

1- A concepção e a construção de uma estação-piloto (EP) para pesquisa de observação e pesquisa experimental das zonas não saturada e saturada da Formação Adamantina (Ks), com localização no Município de Presidente Prudente, Estado de São Paulo, utilizando-se os recursos mais modernos de que se dispõe para este fim;

2- Monitoramento do comportamento hidrodinâmico de um aqüifero livre muito vulnerável, como o aqüífero Adamantina;

3 - Monitoramento, para obtenção de dados de "background" hidrogeoquímico, durante um ano hidrológico, do comportamento químico e físico da água através da zona não saturada, desde a sua infiltração a partir das precipitações pluviais até a sua incorporação ao aqüífero freático;

4 - Monitoramento dos comportamentos físico e químico de substâncias potencialmente tóxicas, que são introduzidas no terreno em estudo e estabelecimento de um padrão de contaminação da zona não saturada e do aqüífero. 


\section{REVISÃO BIBLIOGRÁFICA}

\subsection{PESQUISAS EM HIDROGEOQUÍMICA ATRAVÉS DE EQUIPAMENTOS FIXOS}

De acordo com a bibliografia disponivel, tradicionalmente estações-piloto não são comumente empregadas em estudo da água subterrânea. As pesquisas executadas com equipamento fixo, concernentes à evolução de processos de hidrodinâmica $e$ hidrogeoquímica nas zonas não saturada e saturada têm-se baseado no emprego de lisímetros e colunas muito mais freqüentemente do que em estações piloto. Os métodos associados a estes equipamentos são aplicados predominantemente a pesquisas experimentais.

Com relação a estudos experimentais, trabalhos de especialistas em ciências do solo, interessados geralmente na questão de efeitos de um ou mais tipos de contaminantes no sistema água-solo-planta, vêm contribuindo significativamente para as pesquisas referentes à contaminação da água subterrânea. As discussões e conclusões apresentadas nestes trabalhos são muito diversificadas, sendo extensas em alguns deles, devido ao fato de estarem apoiadas em experimentos com associações variadas das substâncias introduzidas, em de natureza diversa e em variadas condições físicas e temporais de experimentação.

Procedimentos baseados no emprego de lisímetros ou colunas são muito semelhantes entre si, podendo, através deles, ser controladas as condições físicas e químicas de um experimento. Os lisímetros são expostos ao ar livre, enquanto as colunas são próprias de experimentos em ambiente fechado de laboratório. Nos primeiros, em geral o monitoramento é conduzido através de coleta de material lixiviado; no caso das colunas, é comum o emprego de técnicas de extraçăo das substâncias que são objeto do estudo, com amostragem e trituração de solo ou de rocha. Devido à ampla referência bibliográfica a pesquisas executadas através destes equipamentos, algumas delas são aqui selecionadas, por apresentarem diferenças entre si quanto a objetivos e procedimentos. 
BIZELL (1944), em estudo experimental nos Estados Unidos, empregou lisímetros para determinação de perdas, sob forma de lixiviação de nitrato, de fertilizante nitrogenado.

ALLISON (1955) resume resultados de experimentos com 157 lisímetros conduzidos em vários locais dos Estados Unidos, ressaltando o aspecto da perda de fertilizante. Neste caso, os experimentos são orientados para finalidades de caráter econômico, não sendo, portanto, identificados com a preocupação de conservação ambiental.

WAGENET, BIGGAR e NIELSEN (1977) estudaram, através de método de colunas, as transformações de fertilizantes à base de uréia durante um processo de lixiviação. Os experimentos foram desenvolvidos sob condições físicas e químicas controladas, em blocos cilíndricos de $7,62 \mathrm{~cm}$ de diâmetro e comprimentos de 15,23 ou $30 \mathrm{~cm}$, de solo argilosiltoso, envolvidos por colunas de acrílico. Um dos objetivos desse estudo era o desenvolvimento de modelos matemáticos, aplicáveis aos processos de transformação de compostos nitrogenados em seu transporte através do solo.

VEENIS \& BLEUTEN (1989) realizaram experimentos de contaminação de aqüíferos rasos na Holanda, em colunas de $1 \mathrm{~m}$ de comprimento 0,21 $\mathrm{m}$ de diâmetro, onde usaram o material rochoso e a água do próprio aqüífero. Observaram o comportamento de diferentes substâncias artificialmente introduzidas na amostra do aqüífero. Um objetivo de modelagem foi incluído também na pesquisa.

OWENS (1990) apresenta o resultado de experimentos com uma série de 7 lisímetros, aplicados ao estudo do comportamento do nitrato em solos dos Appalaches do Norte. Nesses lisímetros, de $8,1 \mathrm{~m}^{2}$ de área e 2,4 $\mathrm{m}$ de profundidade, instalados em 1971, foram testadas diferentes combinações de solo e rocha amostradas em monolitos, com diferentes combinações de cultura, de doses de adubação e de inclinações da superficie do monolito exposta às chuvas.

DOMERGUE \& VÉDY (1992), pesquisadores de um centro de pesquisa em Pedologia em Lausanne - Suiça, ocupam-se particularmente com a questão da mobilidade de metais pesados no sistema solo-planta. Os estudos relatados por eles baseiam-se em métodos experimentais, que empregam lisimetros de diâmetro de $36 \mathrm{~cm}$.

No tocante a pesquisas sobre água subterrânea executadas através de uma estação experimental, devem ser citados os trabalhos que vèm sendo desenvolvidos na estação instalada no Campus da Universidade de São Paulo, na Cidade Universitá- 
ria, em São Paulo - SP. SZIKSZAY et al (1986) associam a concepção desta estação à problemática da contaminação de aqüíferos subterrâneos. Relacionam também a finalidade de seu funcionamento e a escolha do local de instalação à necessidade de estudo experimental em condições naturais, que propiciam "um monitoramento de todas as variações que ocorrem na zona não saturada, tanto do ponto de vista da dinâmica das águas, como da sua composição química". Esta estação é equipada essencialmente com poços de monitoramento, extratores de água da zona não saturada e tensiômetros.

SZIKSZAY et al (1989) ressaltam o caráter pioneiro da investigação que esta unidade de caráter experimental possibilita e com a qual foi identificado o projeto de sua instalação.

O método de pesquisa que foi desenvolvido a partir do funcionamento desta estação experimental na cidade Universitária de São Paulo/SP serviu como padrão para os procedimentos adotados por ALEXANDRE (1995), em pesquisa aplicada à geoquímica de metais pesados provenientes de pesticidas agrícolas em Louveira/SP.

Com relação a redes de estações de observação e experimentais, MARTELAT et al (1991) apresentam resultados de vários anos de um projeto que integra 12 estações instaladas em área-teste de 2.500 ha na Bacia do Rio Ill na Alsácia. Os trabalhos de monitoramento desenvolvidos nestas estações constituem uma etapa preliminar de um projeto multidisciplinar, dentro de um programa de pesquisas referente a uma área muito mais ampla, com o objetivo de estudar a contaminação da água subterrânea por nitrato no Vale do Reno. Seus resultados estão sendo utilizados também para o desenvolvimento de modelos matemáticos. As Figuras 1 e 2 representam o plano de instrumentação adotado e o equipamento básico de cada estação. Do ponto de vista metodológico, devem ser destacadas duas características básicas desta pesquisa: a adoção da área-teste e a combinação das finalidades de monitoramento de observação e de experimentação para o aperfeiçoamento de métodos de pesquisa hidrogeológica. 


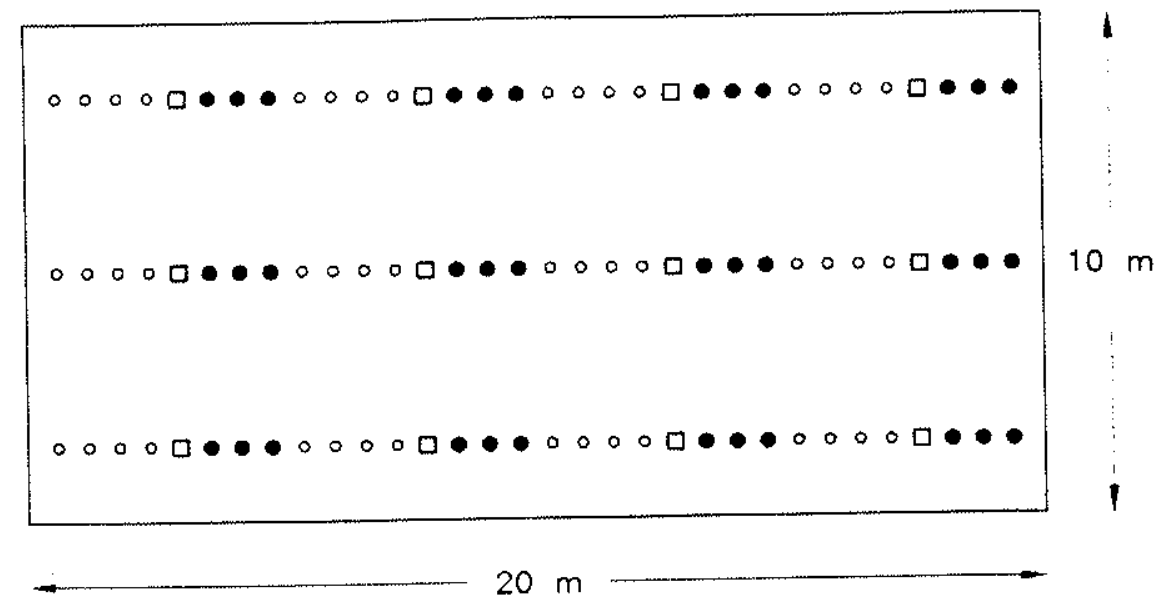

Figura 1: Estação de observação na Planicie Alsaciana - plano de instrumentaçăo

(MARTELAT et al, 1991)

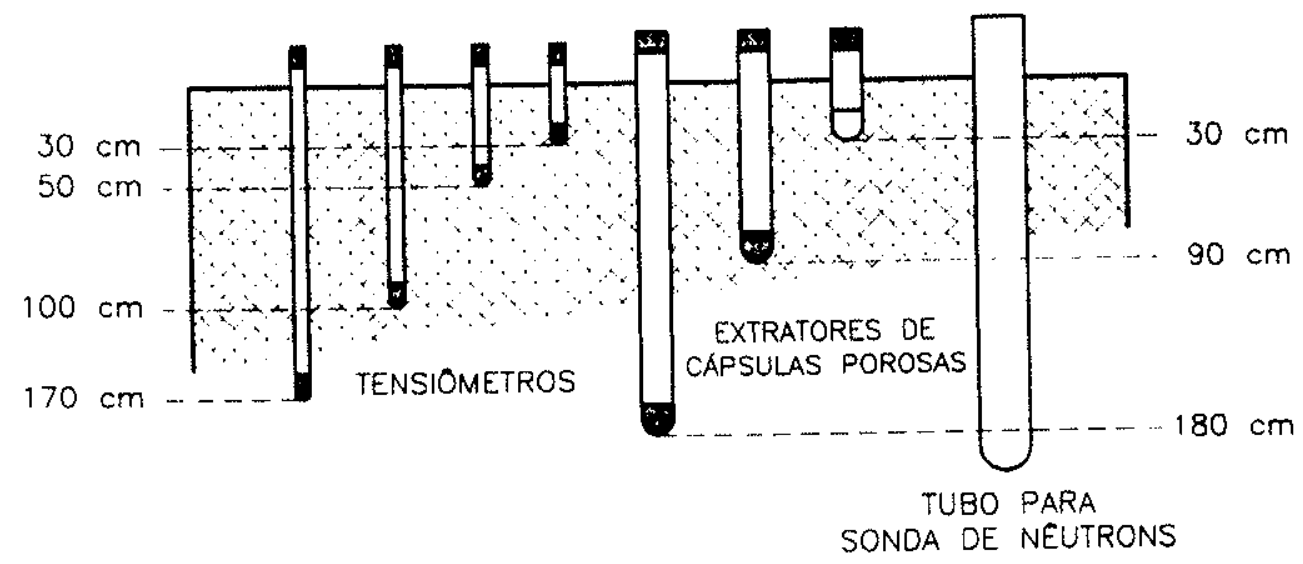

Figura 2: Estaçăo de observaçăo na Planicie Alsaciana - equipamento básico de cada estaçăo 


\subsection{ASPECTOS CE HIDRODINÂMICA EM MEIOS FOROSOS}

A correlação entre características do meio poroso e a hidrodinâmica é um objeto de investigação comum a várias disciplinas, tendo adquirido importância na pesquisa hidrogeológica, assim como na Física de Solos, na Engenharia Aplicada à Irrigação, na Mecânica dos Solos e em estudos voltados à problemática da erosão.

CEDERGREN (1967), na Mecânica dos Solos, considerando a atuação de potenciais gravitacional e piezométrico e a dinâmica do fluxo da água e adotando a Lei de Darcy como fundamento, trata os processos de fluxo de água em meios porosos através de numerosas equações diferenciais parciais, cujo desenvolvimento embasa $o$ tratamento teórico presente nos outros campos de pesquisa acima referidos.

VARGAS (1978) e MARIÑO \& LUTHIN (1982), na "Mecânica dos Solos" também, enfocando a concepção de redes de linhas equipotenciais e linhas de fluxo, ressaltam a analogia da abordagem de fluxo d'água em meios porosos com o tratamento empregado em teorias referentes à condução de energia térmica e condução de energia elétrica.

$\mathrm{Na}$ Hidrogeologia, o tratamento teórico referido acima e o respectivo desenvolvimento de equações diferenciais é adotado no tocante à hidrodinâmica dos meios porosos (FETTER, 1994) e ao transporte de substâncias pela água subterrânea (FETTER, 1993).

Dentro da Física de Solos, LIBARDI (1995) e REICHARDT (1996), em sua abordagem da hidrodinâmica, integram a dinâmica das fases sólida, líquida e gasosa do solo com a atuação das plantas. Devido ao fato de considerarem a atuação dos seres vivos na dinâmica da água no solo, estes autores incluem a concepção de sistema em seu enfoque, considerando fundamental, neste tratamento, o potencial total da fase líquida. Adotam, como base teórica neste enfoque de "sistema", a termodinâmica e suas leis fundamentais. O desenvolvimento de equações é aplicado a fluxo da solução do solo em condição de saturação ou não, fluxo estável, fluxo transiente, assim como ao transporte de substâncias pela água percolante no meio poroso.

$\mathrm{Na}$ Física de Solos e na Hidrogeologia, adota-se, para designar como uma das propriedades hidráulicas do solo, o conceito de condutividade hidráulica $(k)$, de preferência ao conceito de permeabilidade $(K)$, mais utilizado na Mecânica dos Solos, 
uma vez que a condutividade é calculada no intervalo de umidade medido entre a capacidade de campo e a saturação completa (LIBARDI, 1995).

O conceito de permeabilidade é adotado no cálculo da condutividade em condições de saturação total, a uma temperatura estabelecida como padrão (VARGAS, 1978).

Com relação ao potencial total da água no solo, de acordo com REICHARDT (1996), distinguem-se vários componentes, sendo representada a sua atuação, como diferentes variáveis de um sistema complexo em equilíbrio dinâmico, de maneira simplificada, através da seguinte equação:

$\psi=\psi_{\mathrm{p}}+\psi_{\mathrm{g}}+\psi_{\mathrm{os}}+\psi_{\mathrm{m}}$

onde:

$\psi=$ potencial total da água do solo

$\psi_{\mathrm{p}}=$ componente de pressão da altura do corpo hidrico

$\psi_{\mathrm{g}}=$ componente gravitacional

$\psi_{o s}=$ componente osmótica, devida à atuação das plantas

$\psi_{\mathrm{m}}=$ componente matricial, correspondente a todos os trabalhos que

envolvem a interação entre a matriz sólida do solo e a água

\subsection{ZONA NÄO SATURADA}

No ciclo hidrológico, uma parcela da água aportada pela chuva infiltra-se definitivamente no terreno, indo alimentar os aqüiferos subterrâneos. O percurso de infiltração até a chamada zona saturada, isto é, até o nivel freático, é condicionado a fatores de natureza do solo e da rocha, a fatores climáticos e a fatores biológicos.

$\mathrm{Na}$ classificação água de subsuperfície de acordo com a sua localização em zonas, distinguem-se basicamente a zona saturada e zona não saturada (GUYMONT, 1994). Esta última é conceituada como a camada da litosfera que jaz entre a superfície do terreno e o topo do aqüífero livre. É chamada também de "zona de aeração". O ter- 
mo "zona de aeração" implica o fato de que ar e água coexistem na zona não saturada.

A zona não saturada compreende a zona de raiz, a zona intermediária e a franja de capilaridade. A espessura da zona de raiz não é definida com precisão, podendo variar de poucos centímetros a uma dimensão de mais de $1 \mathrm{~m}$. A atuação das raizes influi consideravelmente no comportamento hidrodinâmico do solo.

As espessuras da zona intermediária e da franja de capilaridade são muito variáveis, dependendo da localização da zona saturada e da textura do material constituinte do regolito ou da rocha.

Segundo FETTER (1993), os hidrogeólogos têm muito que aprender com os trabalhos dos cientistas do solo a respeito do transporte de contaminantes através da zona não saturada.

A zona não saturada representa a primeira e mais importante defesa natural contra a contaminação da água subterrânea, uma vez que se localiza numa posição estratégica entre a superfície e a zona saturada e corresponde a um ambiente que, do ponto de vista físico, químico e biológico, é geralmente mais efetivo na atenuação e na eliminação de contaminantes que a zona saturada.

Tanto o solo como a zona não saturada interferem nos mecanismos determinantes da recarga. A questão da recarga é fundamental na problemática da contaminação de aqüíferos. Ela é controlada desde a superfície do terreno, importanto em seu desenvolvimento as características de fluxo na zona não saturada. Um dos fatores condicionantes da recarga é a drenagem através do perfil do solo. Os processos que determinam esta drenagem estão relacionados à capacidade de campo. Esta é identificada como a capacidade de retenção de água do solo após a drenagem do seu excesso. Ela é variável de acordo com a categoria do solo, em função das características físicas e mineralógicas, variando no perfil do solo de acordo com as características de um ou mais horizontes. Em pesquisas aplicadas a variados fins, adota-se para a capacidade de campo, como referência básica, a quantidade retida sob um potencial mátrico de -1/3 Atm, aproximadamente $-32.700 \mathrm{~Pa}$ ou $-327 \mathrm{HPa}$ (REICHARDT, 1988). Acima deste valor de potencial, a drenagem do solo é relativamente rápida; abaixo deste valor, a drenagem é reduzida abruptamente a uma taxa próxima do valor zero. 
A capacidade de retenção de água de um solo pouco interfere na velocidade de fluxo, que depende essencialmente dos fatores próprios de sua condutividade. Esta, no entanto, é função da umidade do solo.

Para REICHARDT (1988), algumas determinações muito utilizadas em projetos de irrigação e particularmente adotadas na Física de Solos, como a capacidade de campo, devem ser incluídos em estudos sobre a recarga de aqüiferos. Cálculos relacionados ao armazenamento de água no solo e ao balanço hídrico também devem integrar estes estudos.

No Reino Unido, um mapeamento geral de risco de contaminação da água subterrânea por nitrato adota a capacidade de campo como variável importante na avaliação dos fatores de risco (JONES \& THOMASSON, 1990). A expressão básica utilizada nesta avaliação é:

$$
X W R=R w-P t w \quad(2),
$$

Sendo:

$X W R=$ excesso de precipitação de inverno $(\mathrm{mm})$

$\mathrm{RW}=$ precipitação total $(\mathrm{mm})$ entre a data de retorno à capacidade de campo e a data do término desta condição

Ptw = evapotranspiração total $(\mathrm{mm})$ no periodo de vigência da capacidade de campo

Nesse projeto foi desenvolvido o sistema e de processamento de dados, denominado LANDIS (Soil Survey's computarised land information system), para a estimativa, em diferentes áreas dos territórios da Inglaterra e do País de Gales, de excesso de água no solo, o qual determina a drenagem em seu perfil.

Este sistema de cálculo de balanço hídrico é aplicado à avaliação da perda de fertilizante nitrogenado através da drenagem interna do solo. A lixiviação do nitrato significa um duplo prejuizo, pelo desperdício de fertilizante e pela contaminação da água subterrânea. 
No cálculo de balanço hídrico, os resultados são indicativos da reposição da água no solo ou na zona saturada. É importante estabelecer uma distinção entre a reposição, a percolação e a redistribuição de água no solo.

O balanço hídrico climatológico possibilita uma orientação de avaliações sobre o excesso e deficiência hídrica, conseguindo-se ter uma noção da reposição de água, enquanto o balanço hídrico real, baseado em medições efetuadas no campo, auxilia $o$ entendimento da distribuição de água no solo. A distribuição depende das condições de equilibrio dinâmico do sistema solo-água-vegetação, podendo incluir, no seu cálculo, as variáveis referentes à atuação das plantas e a heterogeneidade textural ou estrutural. REICHARDT (1996) refere-se à redistribuição como um processo contínuo, que não apresenta interrupções abruptas ou níveis estáticos.

\subsection{FLUXO NA ZONA NÃO SATURADA}

O primeiro condicionador do percurso da água é o solo, entendido em seu conceito de acordo com a Pedologia. O comportamento hidrodinâmico de uma determinada classe de solo está relacionado às características que possibilitam a sua classificação e identificação, principalmente as de natureza morfológica. A bibliografia que trata das correlações entre as propriedades do solo e as suas propriedades hidrodinâmicas é relativamente vasta, sendo ressaltado, em pesquisas experimentais, a complexidade de fatores que devem ser considerados. Aqui é considerado apenas o que pode apresentar uma contribuição prática para a pesquisa realizada na EP, principalmente o que está relacionado a fluxos em meios heterogêneos e o fluxo preferencial.

Com relação à característica de heterogeneidade, ela deve ser considerada no tocante aos solos encontrados na Região Oeste do Estado de São Paulo. FREIRE et al (1991), em pesquisa referente à erodibilidade de solos nesta região, empregam uma escala em 5 graus, proposta por WISCHMEIER et al (1971) para a classificação dos solos quanto à condutividade hidráulica, incluindo-a como um dos elementos para a montagem de equações aplicadas a cálculos de índice de erodibilidade. Em estudo aplicado à problemática da erosão em áreas de cabeceiras ao redor da cidade de Bauru - SP, SALOMÃO (1994) destaca a influência da diferenciação marcante dos horizontes de solos podzólicos, assim como a sua continuidade lateral como um fator de 
controle do fluxo de água sobre a hidrodinâmica através de seu perfil. Os horizontes "B", relativamente menos permeáveis que os horizontes sobrepostos, funcionam como barreira à infiltração da água e favorecem o fluxo lateral. Este comportamento de drenagem origina um fluxo que pode ser denominado de "subsuperficial".

Quanto ao fluxo preferencial, de acordo com MIYAZAKI (1993), é amplamente reconhecida a sua influência nos processos hidrológicos dos solos. O seu papel na hidroquímica e na contaminação da água subterrânea, dada a sua importância, tem sido tema específico de vários simpósios.

Dentre os componentes morfológicos do solo que favorecem o fluxo preferencial, são destacados os macroporos, as fendas e as biocavidades e.

De acordo com LUXMOORE \& FERRAND (1993), no tocante ao papel dos poros, é importante distinguir ao menos duas escalas de fluxo preferencial. Em um caso, que é o da interligação de macroporos, a água move-se através de uma rede de cavidades, comumente bioporos, cujo diâmetro ou largura é maior que $1 \mathrm{~mm}$; no outro caso, referido como interligação de mesoporos, a água flui através de redes de gretas e canais de diâmetro ou largura inferior a $1 \mathrm{~mm}$, mas em dimensão que ainda possibilita a drenagem por influência do potencial de gravidade.

Poros que retêm água por tensão superficial abaixo da capacidade de campo são referidos como microporos, armazenando por tempo variável o que pode ser denominado "água velha" num terreno drenado. "Água nova" introduzida por eventos de precipitação geralmente apresenta composição química diferente da água que tem um determinado intervalo de tempo de residência no solo. Esta distinção pode ser usada para estimar as contribuições, para o fluxo preferencial, da água velha e da água nova.

Outras formas de fluxo preferencial são devidas à heterogeneidade na distribuição espacial dos poros interligados ou heterogeneidade associada à diferenciação dos horizontes no solo.

Deve ser ressaltado que, no aspecto do fluxo na zona não saturada, a bibliografia carece de uma visão integradora entre o solo como entidade pedológica, o regolito e o substrato de rocha de diferentes graus de intemperização. 


\section{MATERIAIS E MÉTODOS}

\section{1. ÁREA DE ESTUDO}

A área da pesquisa está situada no Município de Presidente Prudente, o qual está localizado na porção ocidental do Estado de São Paulo. A sede deste município dista aproximadamente $560 \mathrm{~km}$, por rodovia, da capital do Estado (Figura 3). Por ferrovia, a distância é de $732 \mathrm{~km}$. A via de comunicação mais utilizada entre a capital e Presidente Prudente é a Rodovia Marechal Castello Branco / SP-280, no trecho entre as Cidades de São Paulo e Ourinhos, de onde o trajeto continua pela Rodovia Raposo Tavares/SP-270.

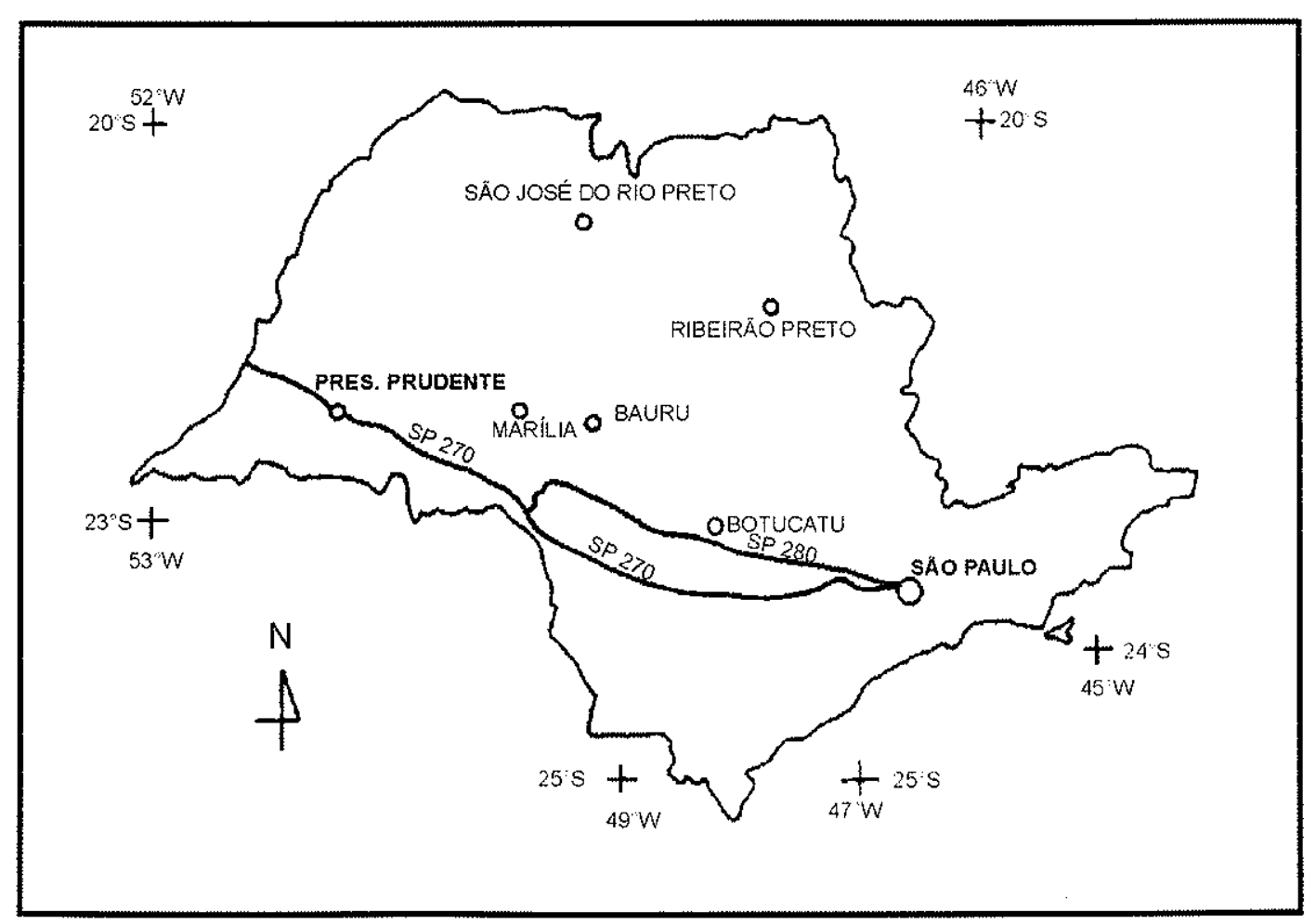

Figura 3: Mapa de localização da área de estudo e principais vias de comunicação rodoviária 
A população do Município, de acordo com o littimo censo demográfico, é de 177.236 habitantes (Fundação IBGE, 1997). A cidade de Presidente Prudente, a exemplo de outras cidades de porte médio do Oeste Paulista, constitui-se num pólo comercial e de atividades de serviços de variada natureza para um território que compreende a Região Administrativa 10 e parte da Região 11, com sede na Cidade de Marília no estado de São Paulo, além de municípios da porção Oeste do Estado do Mato Grosso e outros localizados na Região Norte do Estado do Paraná.

\section{2. CLIMA REGIONAL}

Com relação ao clima vigente na região de Presidente Prudente, é adotada mais comumente a classificação climática de KOPPEN (1948), em combinação com a classificação proposta por MONTEIRO (1973) para o Estado de São Paulo, esta última sendo baseada em critério de distinção de zonas climáticas. De acordo com a primeira classificação, o tipo climático é "Awa" - tropical com estação chuvosa no verão e seca no inverno, onde a temperatura do mês mais quente é superior a $22^{\circ} \mathrm{C}$ e a do mês mais frio é superior a $18^{\circ} \mathrm{C}$; de acordo com a segunda classificaçăo, o clima da região é subtropical de continente, constituindo uma área de influência de massas de ar tropicais e polares, com dominância da massa de ar tropical maritima. O clima regional, classificado em princípio como "Aw", tropical quente e úmido, é perturbado pela circulação atmosférica regional, que confere um caráter de transição climática, caracterizado por variabilidade pluviométrica, com flutuações dos totais de chuvas devidas a caracteristicas geográficas locais (SANT'ANNA \& BARRIOS, 1992).

Os registros obtidos durante 25 anos de funcionamento da Estação Meteorológica do Campus da UNESP de Presidente Prudente podem ser resumidos nos índices apresentados abaixo na Tabela 1. 
iabela 1: Resumo dos registros de temperatura e precipitação em Presidente Prudente de 1969 a 1995 - E.M./FCT/UNESP

\begin{tabular}{|c|c|c|}
\hline \multicolumn{3}{|c|}{$\begin{array}{c}\text { TEMPERATURA } \\
\left({ }^{\circ} \mathbf{C}\right)\end{array}$} \\
\hline $\begin{array}{c}\text { MÉDIA } \\
\text { GERAL }\end{array}$ & $\begin{array}{c}\text { MÉDIADAS } \\
\text { MÁXIMAS }\end{array}$ & $\begin{array}{c}\text { MEDIA DAS } \\
\text { MINIMAS }\end{array}$ \\
\hline 23,1 & 28,9 & 18,2 \\
\hline \multicolumn{3}{|c|}{ PLUVIOSIDADE } \\
PRECIPITAÇÃO ANUAL ACUMULADA \\
(mm)
\end{tabular}

\subsection{HIDROLOGIA}

O território municipal de Presidente Prudente é limitado a N pelo Rio do Peixe e a $S$ e SW, pelo rio Santo Anastácio. Estes dois cursos d'água seguem paralelamente entre si, em direção aproximada de E-W, rumando para $W$, até a sua desembocadura no rio Paraná.

A área urbanizada de Presidente Prudente expande-se a partir do espigão divisor de águas destas duas bacias, avançando, a $N$, a NE e a $E$ dentro da bacia do Rio do Peixe e pelo curso superior do Rio Mandaguari e a S, SW eW, dentro da bacia do Rio Santo Anastácio, pelas suas cabeceiras e pelo curso superior do Córrego do Limoeiro. Observa-se pela Figura 4 que o núcleo urbano é circundado por cabeceiras destes cursos d'água. A área de pesquisa está, portanto, em zonas de cabeceiras de bacias hidrográficas e de cursos superiores da rede fluvial. 


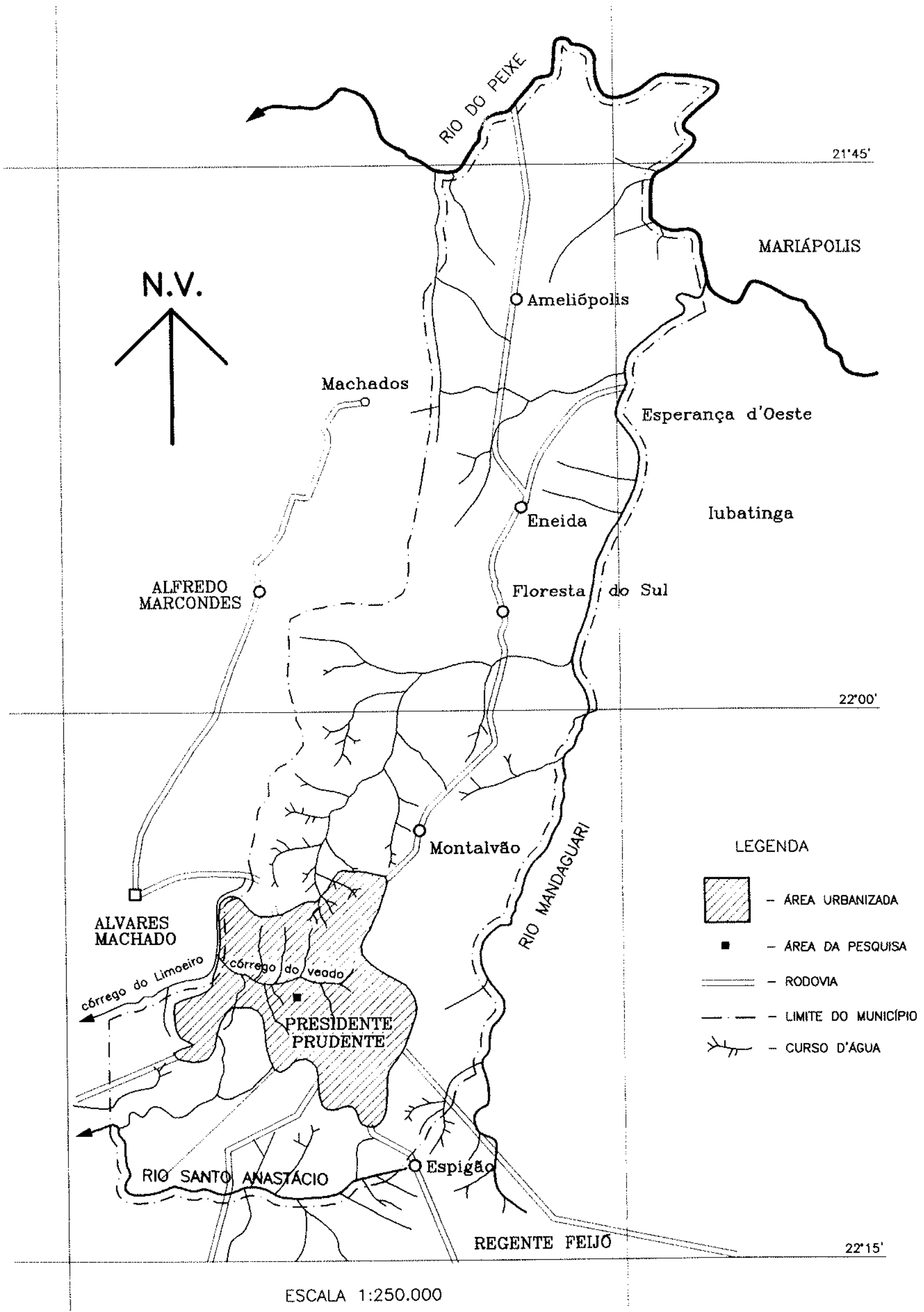

Figura 4 : Localização da área da pesquisa em relação a rede hidrográfica e à matha urbana de Presidente Prudente - SP 
Ao sul, a distância aproximada de $30 \mathrm{~km}$ do limite do município, localiza-se o rio Paranapanema, que segue também o rumo oeste até a sua foz no Rio Paraná.

\subsection{GEOMORFOLOGIA E PEDOLOGIA}

Presidente Prudente localiza-se na região intermediária entre o Rios do Peixe e Paranapanema, na porção SW da extensa provincia geomorfológica denominada por ALMEIDA (1964) de Planalto Ocidental Paulista. Mais de $80 \%$ desta província é localizado em terrenos onde afloram as camadas do Grupo Bauru, com predominância da Formação Adamantina em área (IPT, 1981a). As feições de relevo mais características desta província são reproduzidas em toda a sua extensão, inclusive na região de Presidente Prudente, como se verifica no mapa geomorfológico do Estado de São Paulo ( IPT, 1981b).

A Cidade de Presidente Prudente assenta-se sobre um espigão divisor das bacias das Bacias do Rio do Peixe a N, do Rio Santo Anastácio a S e a SW e do Rio Paranapanema a SE. No interior da bacia do Rio Santo Anastácio, onde se encontra a área da pesquisa, o relevo é caracterizado por interflúvios em colinas onduladas. Nas encostas são relativamente freqüentes as rupturas estruturais, marcadas pela presença de estratos areniticos superficiais ou de solos pouco desenvolvidos (CARVALHO et al, 1997). Relevo de colinas escalonadas refletem o comportamento diferenciado das camadas da Formação Adamantina em relação aos processos de erosão, distinguindose os arenitos mais compactos por sua maior resistência a estes processos.

As formas principais de relevo reconhecidas nesta bacia são comuns à área do Município de Presidente Prudente e áreas vizinhas. Nela predomina um relevo de colina alongada, de topo aplainado, com vertente em geral convexa e de declives inferiores a $6 \%$ nas vertentes dos vales. $O$ relevo de morrotes e colinas escalonadas também são característicos desta região.

Quanto ao regolito, nestas áreas de relevo ondulado a fortemente ondulado, ele raramente apresenta mais do que $5 \mathrm{~m}$ de espessura. Os valores mais comuns de espessura que são observados variam entre $1,5 \mathrm{~m}$ e $4 \mathrm{~m}$ (GODOY, 1989). No terço médio das encostas é comum a ocorréncia de regolito com menos de $1 \mathrm{~m}$ de espessura. 
Do ponto de vista pedológico, de acordo com o levantamento semi-detalhado de solos da Bacia do Rio Santo Anastácio (CARVALHO et al , 1997), incluem a área da pesquisa está localizada na unidade classificada como "Pve4" - PODZOLLCO VERMELHO-AMARELO ABRÚPTICO EUTROFICO Tb A moderado textura arenosa/média fase floresta tropical subperenifólia relevo ondulado (CARVALHO et al, 1997). Trata-se de um terreno bem drenável, embora haja variação vertical na condutividade hidráulica, observando-se a presença de horizontes menos favoráveis à percolação de água. O mesmo levantamento associa a maioria dos solos enquadrados na categoria Podzólico Vermelho-Amarelo e Podzólico Vermelho Escuro ao relevo de colinas onduladas de níveis escalonados, com declividade de 6 a 10\%, Em relevo ondulado a fortemente ondulado, com declividade de 8 a $20 \%$, encontram-se os solos litólicos.

SUDO (1980), em estudo geomorfológico da Bacia do Alto Santo Anastácio, onde está localizada a área desta pesquisa, estuda a dinâmica do escoamento subsuperficial em solos podzólicos, atribuindo a causa deste processo de fluxo lateral ao contraste de condutividade hidráulica entre o horizonte eluvial e o horizonte $\mathrm{B}$ textural sotoposto. Este horizonte, por sua menor condutividade hidráulica, funciona como barreira moderadora do fluxo vertical.

Quanto à cobertura vegetal anterior ao desmatamento generalizado da região, apresentava caracteristicas de floresta tropical pluvial estacional e subperenifblia (FRANCISCO, 1989), podendo ser entendida como uma cobertura de mata exuberante, muito dependente e altamente consumidora de água das chuvas, apresentando também o comportamento de adaptação sazonal, observável na perda parcial da foIhagem. De acordo com FRANCISCO (1989), a remoção de cobertura de floresta tropical influi significativamente no comportamento hídrico do solo, alterando-o quanto à reposição, à redistribuição e à orientação do fluxo d'água. Uma das primeiras consequeencias do desmatamento é o aumento da drenagem no perfil do solo, provocando elevação do nivel freático. Posteriormente, a ausência do regulador térmico representado pela floresta resulta em alterações dos processos associados ao ciclo de umedecimento e ressecamento do solo. Deste modo, quando ocorre o desmatamento, o solo desenvolvido sob matas densas é modificado em suas propriedades relacionadas à hidrodinâmica e em sua própria evolução. 


\subsection{GEOLOGIA}

\subsubsection{Geologia Regional}

O mapeamento geológico em escala 1: 500.000 , executado pelo Instituto de Pesquisas Tecnológicas do Estado de São Paulo, localiza a região de Presidente Prudente em domínios da Formaçāo Adamantina, do Grupo Bauru, Cretáceo Superior da Bacia Sedimentar do Paraná (IPT,1981). Em território paulista, a área de afloramento do Grupo Bauru é muito mais extensa do que as das outras unidades estratigráficas desta bacia (Figura 5).

Pela seqüencia estratigráfica ainda atualmente considerada como a mais aceita, que é aquela adotada por ALMEIDA \& MELO (1981), o Grupo Bauru é subdividido nas Formações Caiuá, Santo Anastácio, Adamantina e Marília.

A Formação Caiuá é constituída predominantemente por arenitos de coloração arroxeada, com marcante estratificação cruzada de grande porte, tangencial na base, de granulação fina a média e muito boa seleção ao longo da mesma lâmina ou estrato, com grâos arredondados a subarredondados.

A Formação Santo Anastácio é constituída principalmente de arenitos de cor marrom-avermelhados a arroxeados, de granulação fina a média, apresentando seleção regular a ruim em geral, com grãos arredondados a subarredondados e cobertos por película limonítica.

A Formação Adamantina caracteriza-se litologicamente pela ocorrência de bancos de arenito de granulação fina a muito fina, de cor róseo a castanho, com espessuras variáveis entre 2 e 20 metros e alternados com lamitos, siltitos e arenitos lamíticos, de cor castanho avermelhado a cinza castanho. Quanto à estrutura, as estratificaçōes cruzadas são próprias dos estratos mais areníticos, ao passo que, nos termos lamíticos subordinados a eles, são mais comuns os bancos maciços ou dispostos em acamamento plano-paralelo, com a presença freqüente de marcas de onda e microestratificaçăo cruzada. 


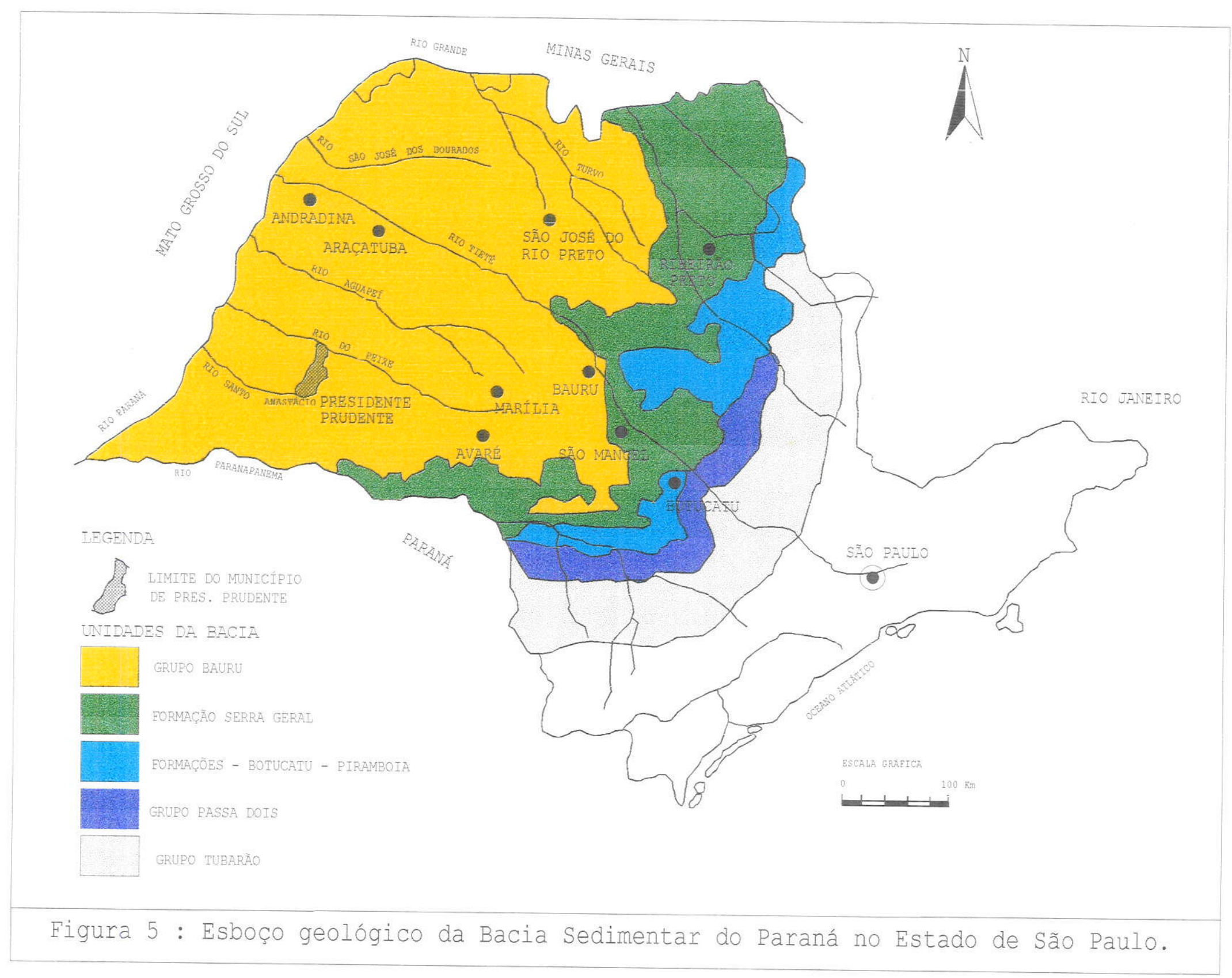


A Formação Marília tem ocorrência restrita em comparação com as demais unidades do Grupo Bauru. É composta por arenitos de grosseiros a conglomeráticos, com grãos angulosos, teor de matriz variável, seleção pobre, ricos em feldspatos, minerais pesados e minerais instáveis. Forma bancos cuja espessura varia predominantemente de $1 \mathrm{~m}$ a $2 \mathrm{~m}$, apresentando estrutura maciça ou de acamamento incipiente, subparalelo e descontínuo. São característicos desta formação os nódulos carbonáticos e a freqüência de cimento carbonático.

Como se observa no mapa geológico (Figura 6), dentre as unidades do Grupo Bauru, a Formação Adamantina é de longe a mais extensa em afloramento no Estado de São Paulo.

\subsubsection{Geologia Local}

CAMPOS (1987), citando outros autores, considera que no território do Município de Presidente Prudente, a Formação Santo Anastácio se estende abaixo da Formação Adamantina, em concordância com a seqüência cronológica da coluna estratigráfica proposta no mapeamento executado pelo IPT. São reconhecidas também transições laterais, interdigitações e outras formas de deposição contemporânea das duas formaçōes (FERNANDES, 1992).

De acordo com ALMEIDA et al (1981), no interflúvio entre os Rios do Peixe e Santo Anastácio, em áreas de relevo ondulado a fortemente ondulado, distingue-se uma subdivisão estratigráfica ou uma fácies da Formação Adamantina, designada como "Kav". Nesta subunidade, é observada a existência de uma gama ampla de estruturas sedimentares, assim como uma concentração maior de bancos de arenito compacto, ou seja, aqueles onde o teor do cimento carbonático é relativamente elevado.

$\mathrm{Na}$ área de estudo e adjacências, tal como na Região de Presidente Prudente em geral, o substrato rochoso é caracterizado por heterogeneidade litológica, com alternancias de estratos areníticos e lamíticos. As Fotos 1 e 2 apresentam detalhes de afloramentos em locais situados no mesmo interflúvio onde é localizada a área da pesquisa. 


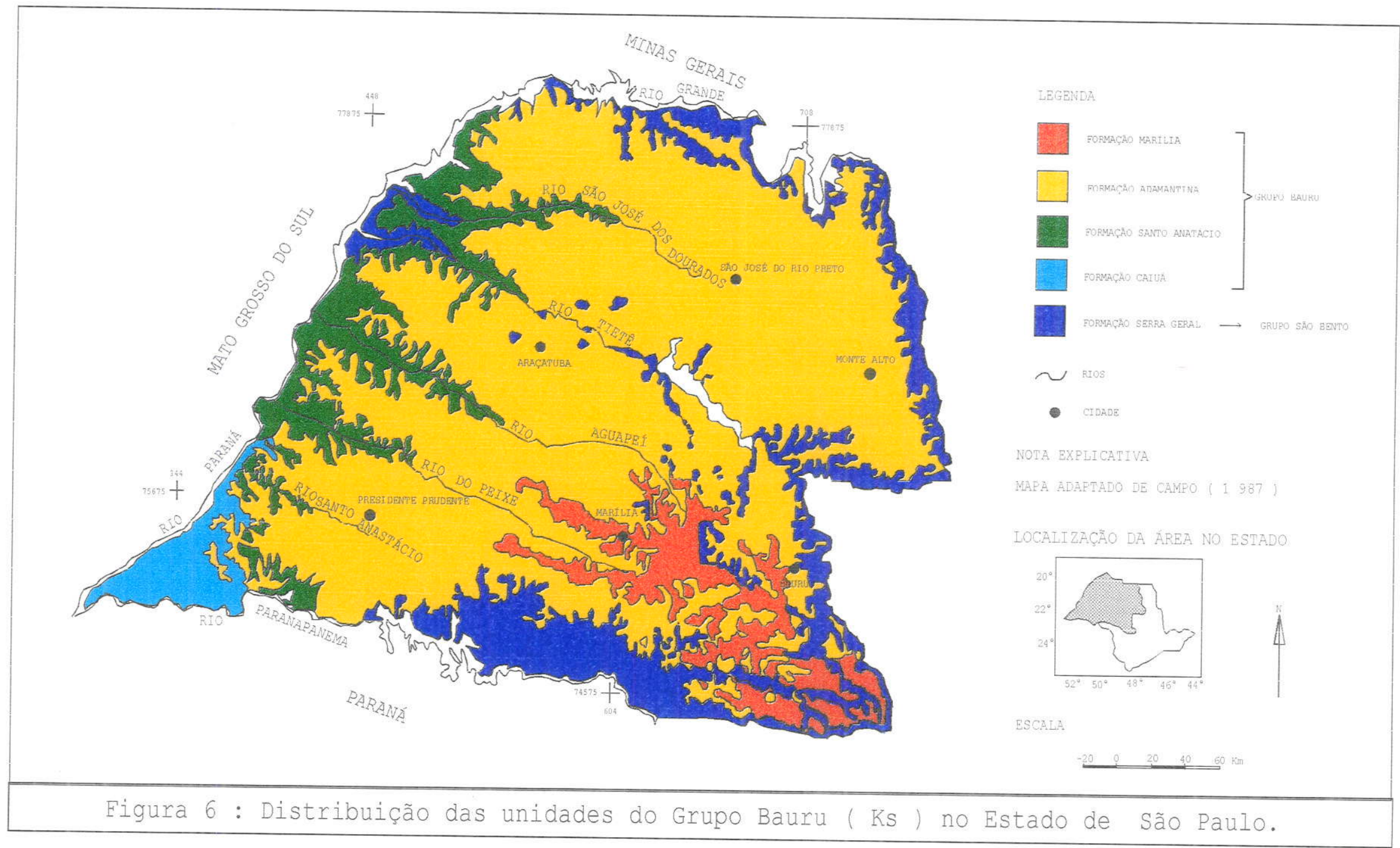


PERUSI et al (1993), em determinações referentes à fração argilosa de lamitos e arenitos da Formação Adamantina na área de estudo, constatam, nos diversos termos litológicos, predominantemente nos estratos lamíticos, a presença de argilominerais de grade 2:1, sendo identificadas montmorillonitas com freqüência, que, de acordo com ZUQUETTE \& GANDOLFI (1987), atuam positivamente como filtro químico da água subterrânea, principalmente na retenção de metais pesados.

\subsection{HIDROGEOLOGIA}

Conforme o mapa hidrogeológico regional, editado pelo DAEE (1979), a Formação Adamantina, então identificada como parte média da unidade estratigráfica classificada ainda como "Formação Bauru", comporta-se como aqüífero livre, sendo a recarga generalizada à toda a sua área de afloramento, determinando assim maior vulnerabilidade à contaminação.

GODOY (1989), através de mapeamento geotécnico da Região de Presidente Prudente, reconhece algumas características específicas da subunidade "Kav" da Formação Adamantina. A característica de cimentação, assim como a intercalação de estratos lamíticos e bancos de arenito, determina a alternância, no perfil do maciço rochoso, de zonas diferenciadas entre si quanto à condutividade hidráulica, conforme se constata comparativamente, na perfuração de poços tubulares, pela presença ou variação na vazão a diferentes profundidades. A alternância de estratos com diferentes comportamentos quanto a este parâmetro hidráulico resulta em vários níveis de saturação dentro do substrato rochoso. A configuração de aqǘferos suspensos se reflete na ocorrência de zonas de ressudação e surgéncias d'água na superficie e também na existência de cabeceiras de nascentes localizadas em níveis diversificados.

Com relação ao nível freático, foi acompanhado, de 1984 até 1988, o comportamento da sua variação em mais de 40 poços rasos no Municipio de Presidente Prudente (GODOY,1989). Estes registros foram acrescentados àqueles fornecidos por medições em poços de monitoramento no Campus da FCT/UNESP no estudo desen- 


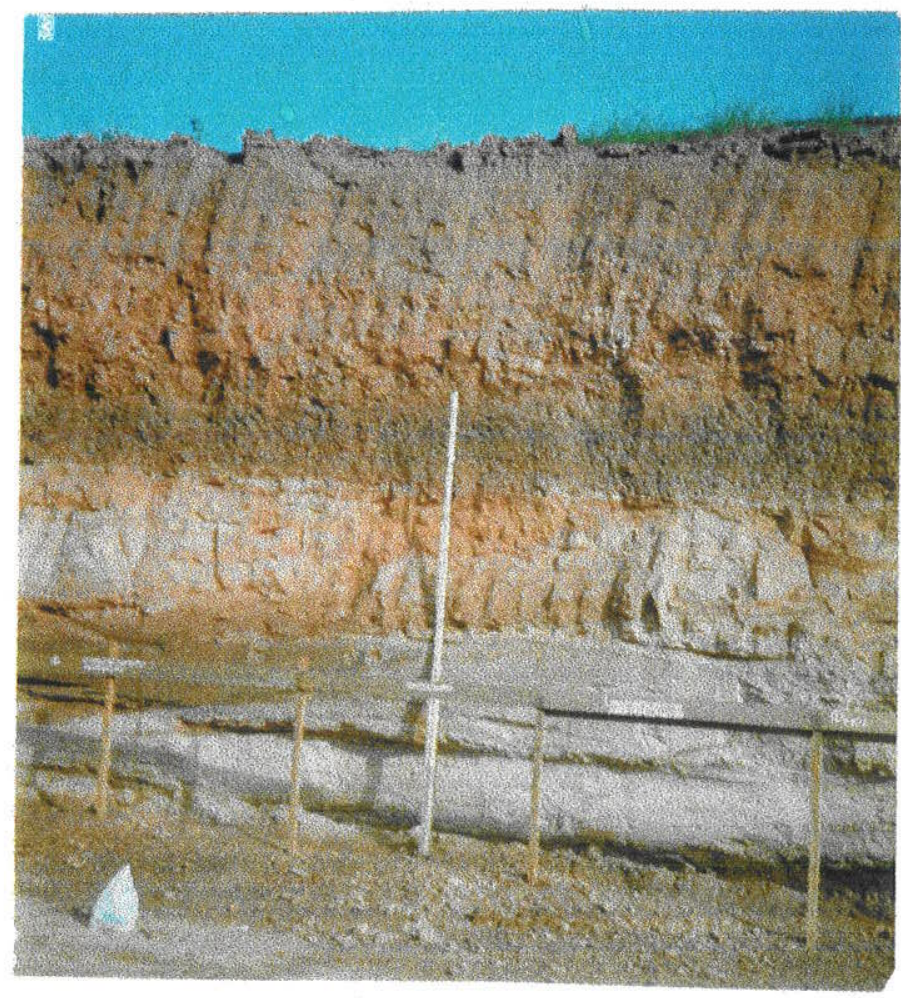

Foto 1: Zona não saturada detalhe em corte, a cerca de $700 \mathrm{~m}$ da EP

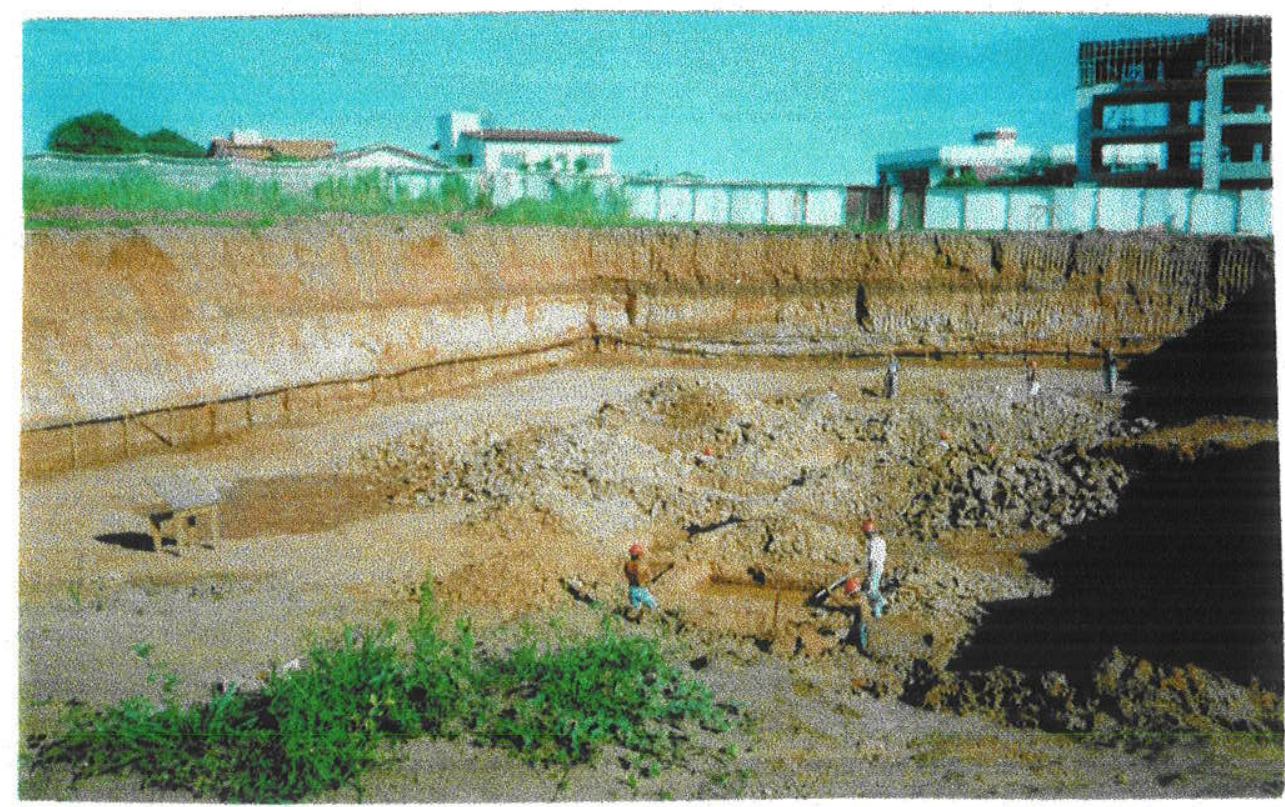

Foto 2: Vista de corte na zona não saturada - a cerca de $700 \mathrm{~m}$ da EP 
volvida a partir da EP. Esse levantamento possibilitou o reconhecimento de padrões, válidos para grande parte do território do Município de Presidente Prudente e adjacências, referentes à profundidade da zona saturada: no setor de topo aplainado do interflúvio, o limite superior da zona permanentemente saturada encontra-se a profundidades entre $10 \mathrm{~m}$ e $15 \mathrm{~m}$ da superfície, registrando-se aqui a menor oscilação sazonal; no terreno de encosta os valores de profundidade estão entre $4 \mathrm{~m}$ e $10 \mathrm{~m}$ e no sopé da encosta ou nos fundos de vales variam entre $2 \mathrm{~m}$ e $5 \mathrm{~m}$, com as maiores oscilações sazonais verificadas.

Foi constatado que nas áreas de topo aplainado, a oscilação sazonal do nivel freático é relativamente pequena (GODOY, 1989). Foi observado também nestas áreas que, no ano de 1985, identificado como o de mais baixa pluviosidade nos últimos 25 anos ( 841,9 mm em Presidente Prudente, de acordo com os dados da Estação Meteorológica da FCT/UNESP), a conseqüência da escassez relativa de chuvas não foi significativa nestas zonas de topo, em contraste com o reflexo nítido de baixa de nível nas áreas de meia encosta e de fundos de vale, que atingiu valor de $4 \mathrm{~m}$ em alguns casos. Por estas constatações, infere-se que haja uma reserva de água de anos anteriores, que não entra propriamente no balanço anual de descarga e recarga. As informações assim obtidas revelam a existência de uma reserva permanente de água no aqüífero livre. Esta reserva, embora sofra influência da recarga sazonal, determina um comportamento de uniformidade nesta localização do nivel freático, uma vez que os valores de oscilação sazonal são em média menores que $0,8 \mathrm{~m}$, raramente ultrapassando o intervalo de $1,1 \mathrm{~m}$, que é pequeno em proporção às variações medidas nas áreas de terço inferior das encostas, como é mencionado acima. Devido à taxa de escoamento superficial, às características do maciço rochoso, ao fator da evaporação e a outros de natureza climática, a contribuição anual de recarga dos aqüíferos aparentemente não interfere substancialmente na reserva existente nestas áreas de topo aplainado (GODOY,1989).

Um fenómeno comum nas bacias hidrográficas do Oeste do Estado de São Paulo é o aparecimento de surgências pontuais de água, as quais em geral são devidas ao fluxo preferencial em zonas de fraturamento ou a fendas no substrato rochoso (GODOY, 1989). Os cortes artificiais nos locais destas surgências intersectam redes de fendas, donde brotam outras surgências. 
Quanto à relação entre as unidades do Grupo Bauru na área analisada, de acordo com perfis litológicos de poços explotados pela SABESP S/A e a amostragem realizada em testemunhos de poços, os depósitos da Formação Adamantina predominam desde a superficie do terreno até a cota aproximada de $340 \mathrm{~m}$, funcionando como aqüífero freático (GODOY,1997). Entre as cotas $280 \mathrm{~m}$ e $340 \mathrm{~m}$, é localizada uma zona de transição entre esta formação e a Formação Santo Anastácio, sotoposta. Abaixo da cota $280 \mathrm{~m}$, predomina esta última, que, no território do Município de Presidente Prudente, se comporta como aqüífero semi-confinado e revela melhor desempenho para a explotação de água que a Formação Adamantina.

O poço tubular profundo instalado no Campus da FCT/UNESP, representado em perfil na Figura 7 e localizado pela Figura 11, caracteriza-se pelos seguintes dados técnicos:

- cota de boca: $439,30 \mathrm{~m}$

- profundidade total: $198 \mathrm{~m}$

- NE: $85 \mathrm{~m}$

- ND: $133 \mathrm{~m}$ de profundidade

- vazão: $29 \mathrm{~m}^{3} / \mathrm{h}$ inicialmente e $21 \mathrm{~m}^{3} / \mathrm{h}$ atualmente.

No perfil geológico deste poço, é registrada a presença, crescente com a profundidade, de camadas da Formação Santo Anastácio, também do Grupo Bauru, em alternância com estratos da Formação Adamantina, a partir de $80 \mathrm{~m}$ de perfuração, com predominância a profundidades maiores que $140 \mathrm{~m}$, indicando que grande parte da água explotada neste poço provém da Formação Santo Anastácio . 


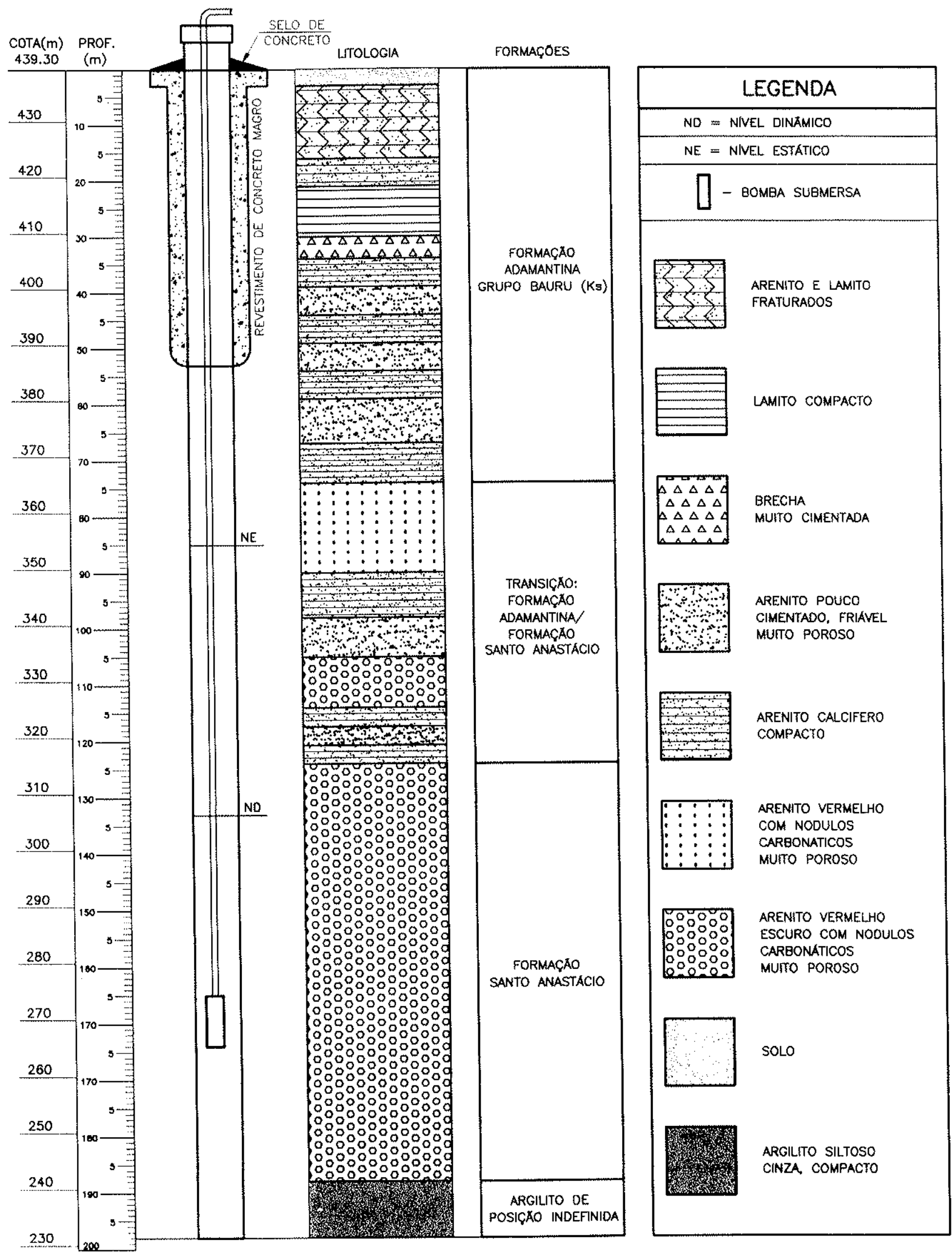

ESCALA VERTICAL $\quad 1: 1.000$

Figura 7 : Perfil geologico do poço tubular instalado no campus do FCT/UNESP 


\subsection{ESCOLHA DA ÁREA DE INSTALAÇÃO DA EP}

O Campus da UNESP está localizado em setor parcialmente urbanizado do Município, a $W$ do núcleo urbano mais antigo e à distância, pelas principais vias de comunicação, de aproximadamente $2,6 \mathrm{~km}$ do marco central da cidade.

A área do Campus, de $380.827,50 \mathrm{~m}^{2}$, ocupa uma parte de um interflúvio, o qual mede cerca de $950 \mathrm{~m}$ de largura, estando limitado a NE pelo Córrego do Veado e a SW por um dos afluentes da margem esquerda do referido curso d'água. O Córrego do Veado está localizado na Bacia do Rio Santo Anastácio, em um dos setores de cabeceiras, correspondente ao trecho considerado como "Alto Santo Anastácio". Encontra-se

A área onde está instalada a EP foi selecionada de acordo com critérios de representatividade relativa à região no tocante aos aspectos geológicos e hidrogeológicos, à facilidade de acesso, à autorização dos responsáveis ou proprietários quanto ao uso para a finalidade de pesquisa e à possibilidade de coleta de informações sobre o meio físico.

A análise dos atributos reunidos pelas diferentes áreas favoreceu a escolha da área localizada no Campus da UNESP. Esta área apresenta Dentre as várias condiçōes adequadas à instalação da EP nesta área, podem ser apontadas as seguintes:

- representação em folha topográfica em escala 1:2.000;

- localização dentro da área escolhida de um setor de pomar, de aproximadamente 2 ha de extensão, pouco aproveitado e protegido por cercas elevadas, apresentando um solo não descaracterizado pedologicamente pelo trato agrícola e de espessura variável entre 3 e $5 \mathrm{~m}$.

- identificação, na área do Campus, do ponto de vista pedológico, de três classes de solos pelo menos, os quais são preliminarmente classificados dentro das categorias genéricas podzólico vermelho amarelo-textura média, solo litólico e solo hidromórfico; 


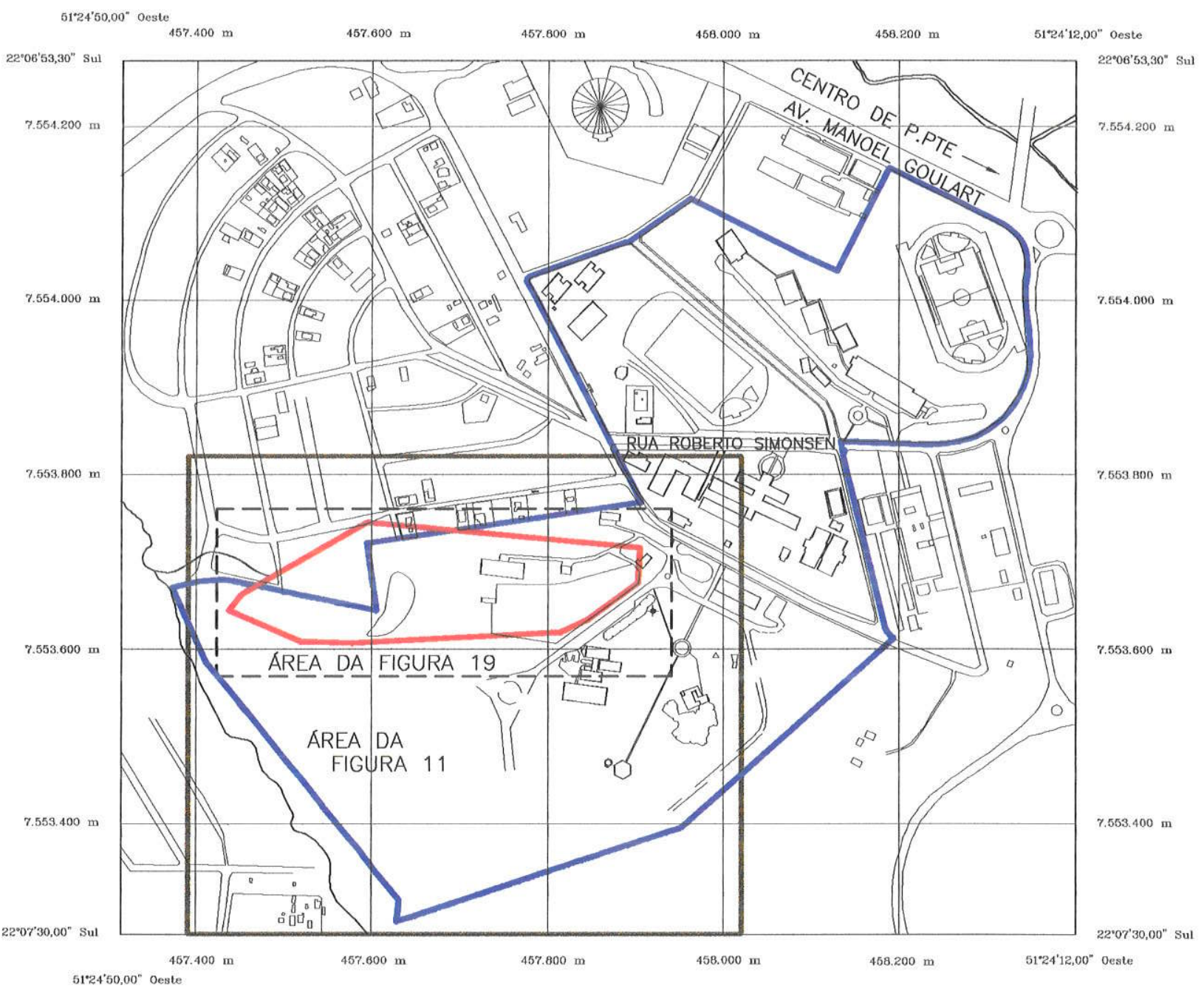

ESCALA $1: 7.500$

LEGENDA

- AREA DO CAMPUS

- AREA INICIAL DA PESQUISA

- ÁREA FINAL DA PESQUISA

Figura 8 : Localização da área da pesquisa em relação ao campus da FCT/UNESP 
- espessura máxima de 14,5 m da zona não saturada, conforme dados de medidas em cacimbas e em fundações de edificações, tanto no Campus como em áreas circunjacentes a ele;

- ocorrência, na área do Campus, de 2 zonas de ressudação de água, 2 locais de surgência, tendo sido conservadas 2 cacimbas dentre aquelas levantados anteriormente, onde a variação do nivel freático é sistematicamente medida desde 0 ano de 1994;

- condição de pronto acesso a qualquer dos laboratórios da Faculdade de Ciências e Tecnologia da UNESP;

- existência no Campus de estação meteorológica bem equipada e integrada à rede nacional de estações, em funcionamento desde 1969;

A partir da EP, a pesquisa foi estendida a uma área de encosta do setor $W$ do Campus, a qual mede $220.540 \mathrm{~m}^{2}$ de extensão. Na Figura 8 são representados os limites do Campus da FCT - UNESP e a área da pesquisa, a qual é representada particularmente em planta planialtimétrica (Figura 11 ).

O pomar onde está instalada a EP é localizado na porção $S$ da área do Campus, em vertente da margem direita de um córrego afluente do córrego do Veado. Esta vertente apresenta perfil predominantemente convexo, com declives variados. Dentro da área do pomar, a declividade varia entre $3 \%$ e $5 \%$ na sua maior parte, chegando localmente a $9 \%$.

A área escolhida é reservada há mais de 20 anos para ser ocupada restritamente com um pomar. Parte do equipamento instalado para a pesquisa, inclusive 3 poços de monitoramento, está fora do perímetro do pomar, a distâncias variáveis do local principal das instalaçōes.

De 1975 a 1980, uma parte da área do pomar foi utilizada para cultivo de uva, onde houve aplicação de agrotóxicos . Atualmente este local é ocupado por uma es- 
tufa para cultura de hortaliça, instalada em maio de 1996 e adubada regularmente com estrumes bovino e suíno.

O setor de pomar atualmente agrupa árvores de espécies variadas, as quais foram aqui plantadas há pelo menos 20 anos. Todo o cuidado de conservação do pomar resume-se à remoção periódica da vegetação rasteira que se alastra abundantemente por entre as árvores. Devido à predomináncia de espécies consideradas rústicas e de frutificação nitidamente sazonal, como mangueiras (Mangifera indica), limeiras (Citrus bergamia) e goiabeiras (Psidium guayava), a prática de irrigação ou adubação é dispensada neste pomar. Nos arredores da área do pomar, o terreno é ocupado por edificações, áreas pavimentadas, pequenos bosques ornamentais e amplos gramados, sendo estes últimos formados de grama Batatais (Paspalum notatus), nitidamente rústica. A irrigação é limitada aos jardins circundantes das edificações. Deve-se considerar que o terreno onde é locada a EP está livre da penetração de água que não seja a da chuva.

Outros componentes devidos à interferência antrópica na área da encosta onde se localiza a EP foram praticadas entre agosto de 1995 e agosto de 1996, consistindo em:

- um açude, de cerca de $80 \mathrm{~m}$ de comprimento, a jusante da área do pomar, onde a superficie interna de contato com a água recebeu tratamento de impermeabilização ;

- terraceamento nos terços médio e inferior da encosta;

- repovoamento da vegetação nativa, com plantios de mudas de espécies muito variadas, com aplicação de adubo NPK.

Das intervenções antrópicas mais recentemente praticadas no Campus o terraceamento é particularmente prejudicial aos os trabalhos da pesquisa, por ter encoberto afloramentos rochosos e ter soterrado surgências. 


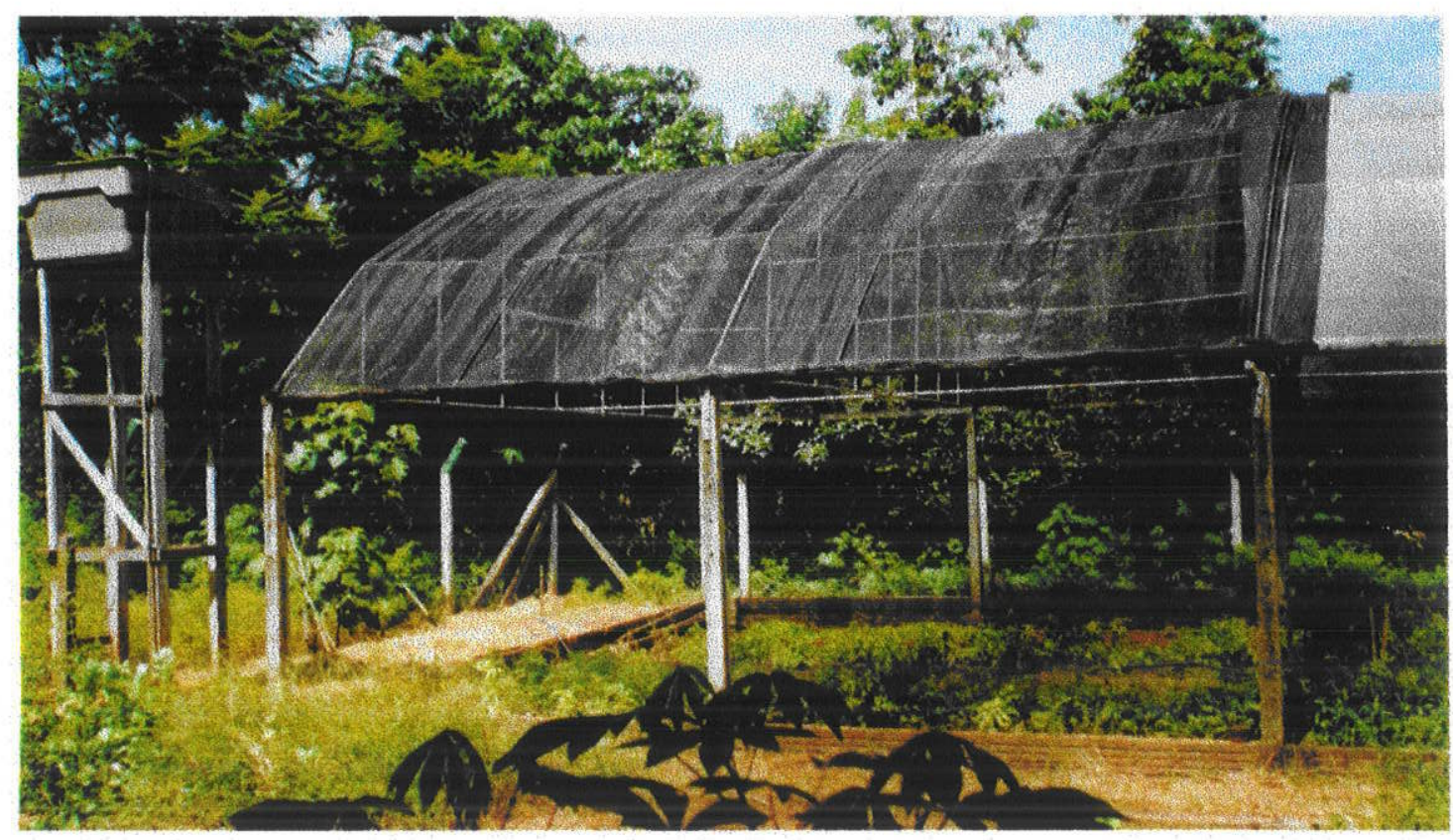

Foto 3: Área do pomar - estufa para hortaliças

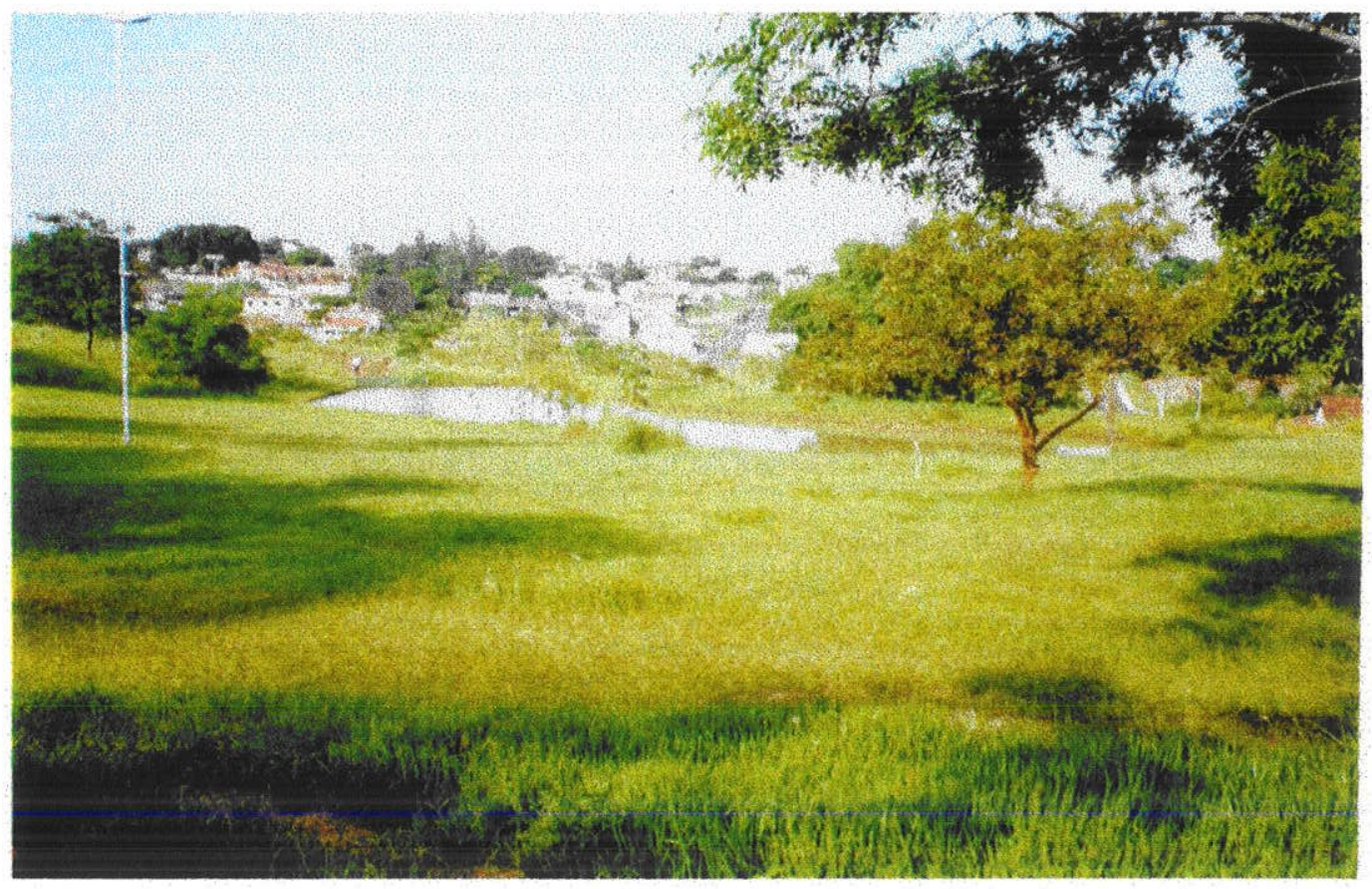

Foto 4: Encosta W do Campus da FCT/UNESP - açude 


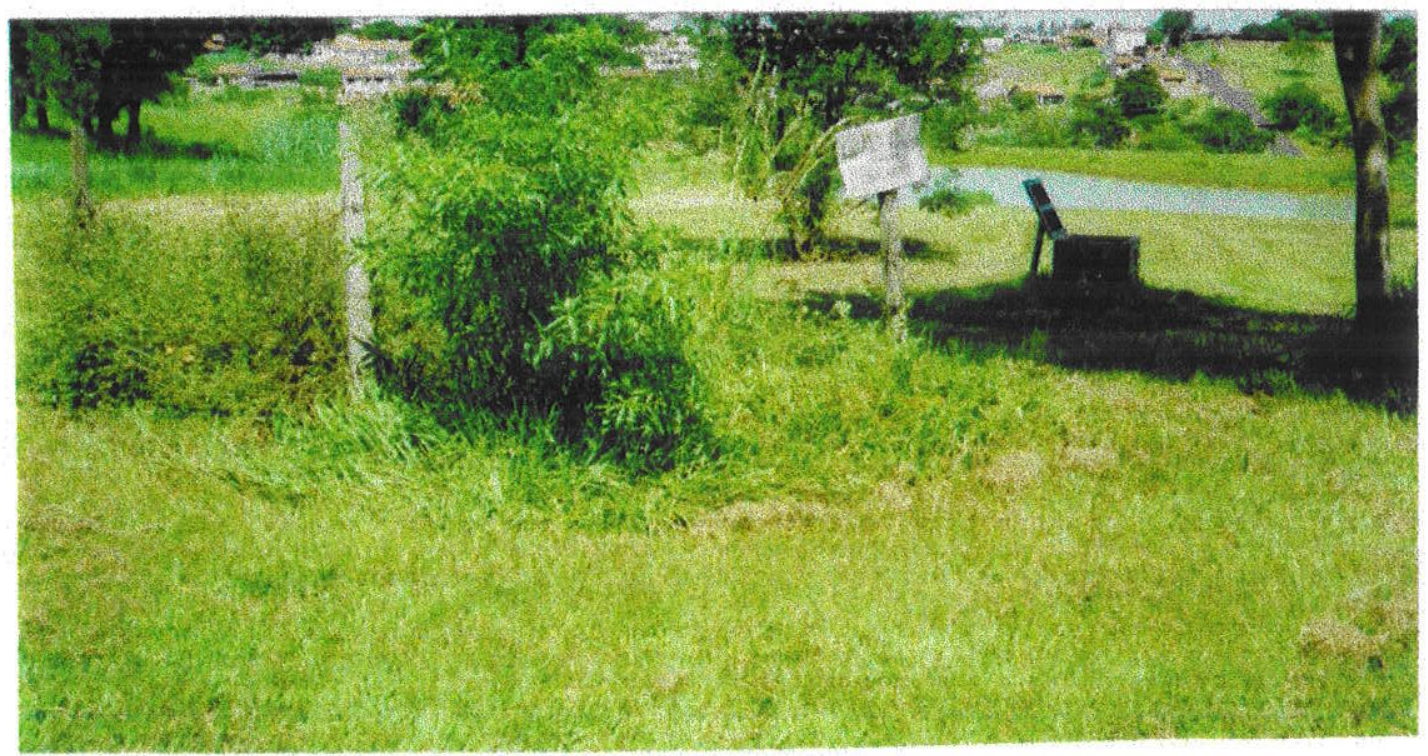

Foto 5: Depósito de lixo do Laboratório de Sedimentologia - FCT/UNESP

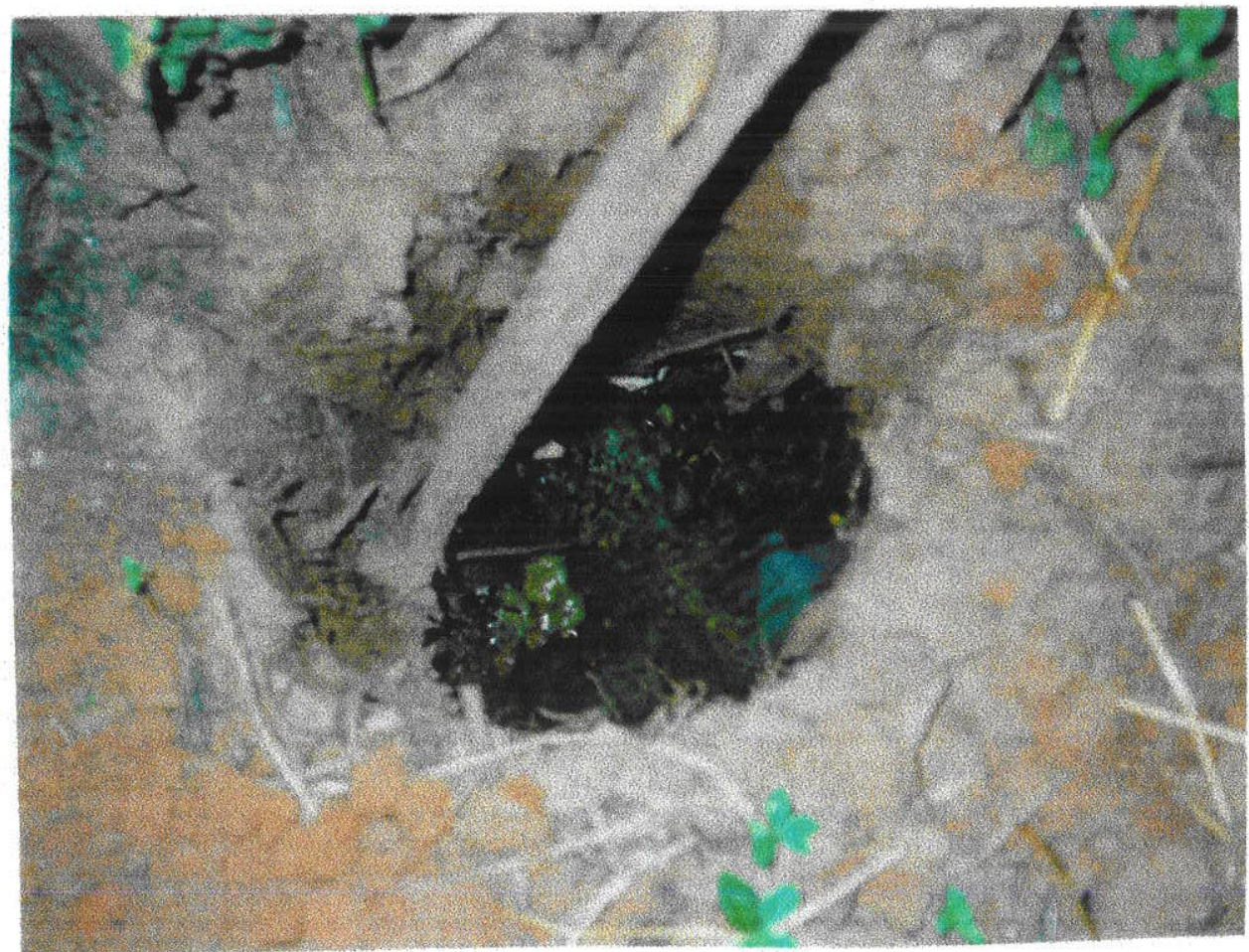

Foto 6: Detalhe do vazamento de coletor de água residuária 
Ainda com referência ao uso da área de pesquisa, foi utilizada, de 1985 até 1991, uma fossa de $3 \mathrm{~m}$ de profundidade para disposição de resíduos tóxicos provenientes de análises químicas de solos, efetuadas no Laboratório de Sedimentologia da FCT/UNESP. Esta fossa está localizada no trecho de encosta intermediário entre a área do pomar e o local do açude recentemente construído. $O$ rejeito ai depositado contém restos de substâncias empregadas na execução das análises, tais como:

dicromato de potássio $1 \mathrm{~N}$, ácido sulfúrico concentrado, ácido fosfórico, difenilamina a $1 \%$ dissolvida em ácido sulfúrico e sulfato ferroso amoniacal $0,4 \mathrm{~N}$.

A borra proveniente das análises de 3.000 amostras de solo, com volume de aproximadamente $250 \mathrm{ml}$ para cada amostra, constituiu-se predominantemente de matéria orgânica impregnada com os reagentes mencionados acima e tratada, para neutralização da acidez,com cal virgem

Detalhes dos componentes do meio ambiente acima referidos são focalizados nas Fotos $3,4,5$ e 6 .

\subsection{CONSTITUIÇÃO DA EP}

$\mathrm{Na}$ EP propriamente dita, está concentrada grande parte dos aparelhos em funcionamento (Figura 9).

O equipamento fixo da constitui-se basicamente de poços de monitoramento, extratores de água da zona não saturada, medidores do potencial mátrico do solo e sistema de medição do escoamento superficial. 
Foram instalados 7 poços de monitoramento, com as seguintes profundidades:

$$
\begin{aligned}
& \text { PM01 - 14,5m } \\
& \text { PM02 - 14,5 m } \\
& \text { PM03 - 13,3 m } \\
& \text { PM04 - 11,6m } \\
& \text { PM05 - 6,60m } \\
& \text { PM06 - 7,70m } \\
& \text { PM07 - 8,50m }
\end{aligned}
$$

Extratores de água da zona não saturada ou lisímetros de sucçăo, dotados de cápsulas porosas, foram instalados primeiramente na área onde se encontra a maior parte dos equipamentos da pesquisa, às seguintes profundidades:

$$
\begin{aligned}
& 0,20 \mathrm{~m} ; 0,50 \mathrm{~m} ; 1,00 \mathrm{~m} ; 1,50 \mathrm{~m} ; 2,00 \mathrm{~m} ; 2,50 \mathrm{~m} ; 3,00 \mathrm{~m} \\
& 4,00 \mathrm{~m} 5,00 \mathrm{~m} ; 6,00 \mathrm{~m} ; 8,00 \mathrm{~m} ; 10,00 \mathrm{~m} ; 12,00 \mathrm{~m} \text { e } 13,00 \mathrm{~m}
\end{aligned}
$$

Uma segunda série de lisímetros de sucção foi instalada nas proximidades da estufa de hortaliças, em área onde havia um parreiral. As cápsulas estão às seguintes profundidades:

$$
0,20 \mathrm{~m}, 0,50 \mathrm{~m}, 0,90 \mathrm{~m}, 1,50 \mathrm{~m} \text { e } 2,50 \mathrm{~m}
$$

Uma série de 7 tensiômetros de marca APAGER, com medidor de mercúrio foi instalada às seguintes profundidades de medição:

$$
0,2 \mathrm{~m} ; 0,5 \mathrm{~m} ; 1 \mathrm{~m} ; 1,5 \mathrm{~m} ; 2 \mathrm{~m} ; 2,5 \mathrm{~m} \text { e } 3 \mathrm{~m} \text {. }
$$

$\mathrm{Na}$ EP , também estão instalados 6 blocos de gesso Soilmoisture, a profundidades de $0,2 \mathrm{~m}, 0,5 \mathrm{~m}, 1 \mathrm{~m}, 1,5 \mathrm{~m}, 3 \mathrm{~m}$ e $4,7 \mathrm{~m}$, cuja variação na resistência elétrica é lida num medidor de resistência elétrica, portátil, modelo 5910-A da Soilmoisture, especificamente desenvolvido para esta finalidade de medida de potencial mátrico. 

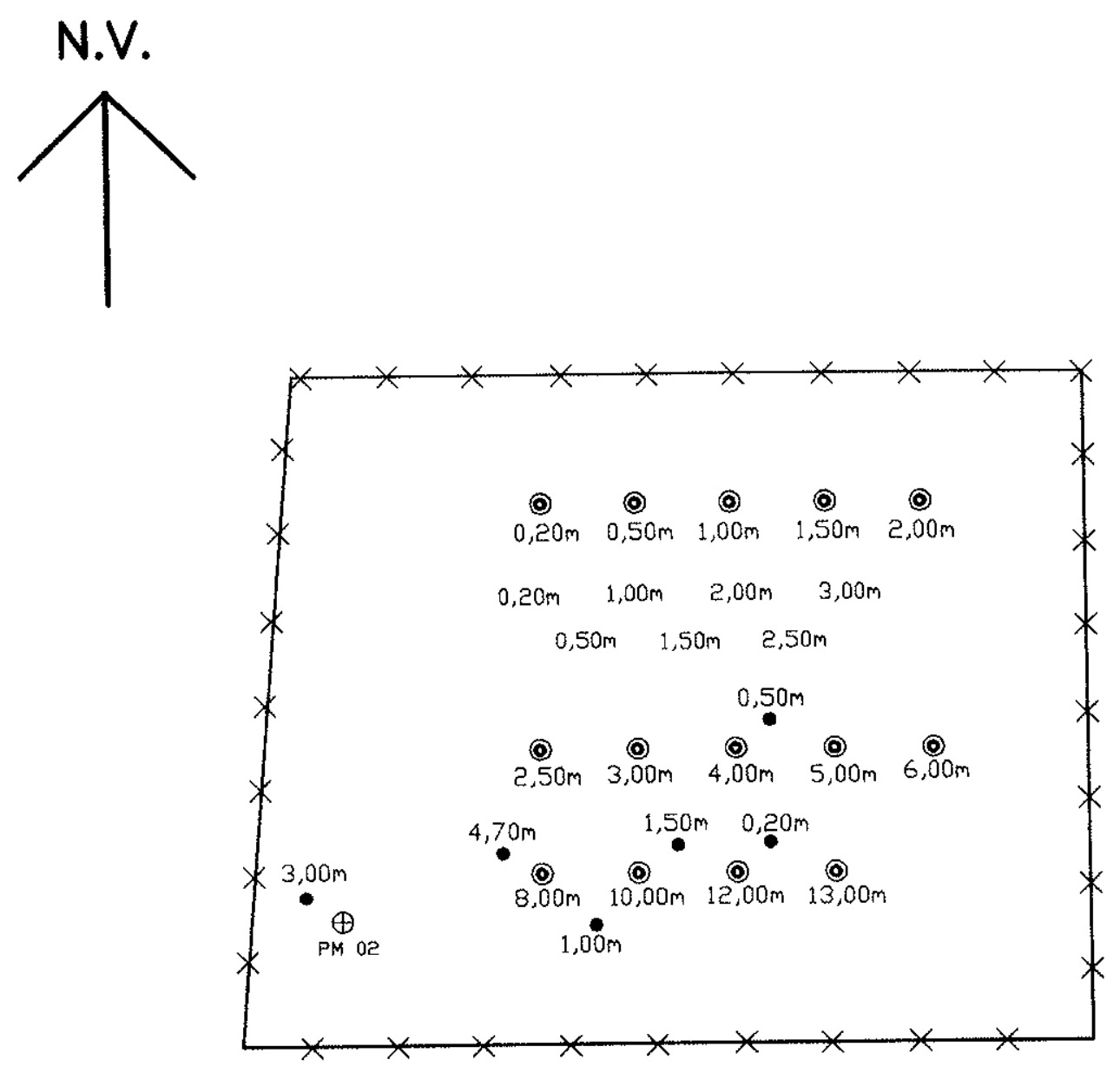

LEGENDA

- Blocos de gesso

$\square$ Tenslometro

* Cerca

$\bigoplus$ Poço de Monitoramento

(O) Extrator de água com capsula porosa
LOCALIZAÇÃO NA AREA DO POMAR FCT/UNESP

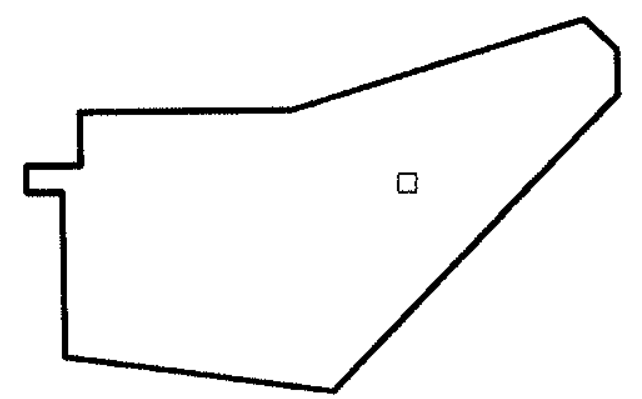

Figura 9

PLANTA DA ESTAÇAO PILOTO: LOCALIZAÇAO DOS TENSIOMETROS E EXTRATORES DE AGUA COM CAPSULAS POROSAS E BLOCOS DE GESSO. 
Junto à E P é instalado um canteiro de deflúvio superficial (CDS). Trata-se de equipamento destinado a medir, a cada evento de precipitação, a parcela de água da chuva que atinge a superfície do terreno e escoa por ela. A área que recebe a precipitação pluvial mede $25 \mathrm{~m} \times 2 \mathrm{~m}$.

A pesquisa contou com o apoio de uma estação meteorológica integrada à rede nacional de estaçöes. Ela é constituída de 5 ambientes, que totalizam 36 apareIhos, localizados de acordo com os critérios adotados pela WMO (Organização Meteorológica Mundial), conforme suas funções. Os ambientes estão assim equipados:

Abrigo meteorológico: termômetros de bulbo seco e bulbo úmido, termógrafo, termo-hidrógrafo, evaporígrafo de Piché .

Bateria de geotermômetros: termômetros de medição de temperatura do solo em relva seca, relva natural e solo nu.

Instrumentos localizados no interior do escritório central: barógrafo, barômetro de mercúrio, anemógrafo, heliógrafo e piranógrafo.

Tanque classe A: anemômetro, termômetro e micrômetro.

Aparelhos dispersos: aspergigrafo, pluviômetro, pluviógrafo, orvalhógrafo e evapotranspirômetro.

\subsection{DESENVOLVIMENTO DA PESQUISA}

O método é orientado na execução de uma pesquisa de caráter experimental, com base no funcionamento de uma EP. Com esta proposição, o estudo é desdobrado em diferentes etapas, as quais estão apresentadas no Quadro 1.

A instalação dos equipamentos foi iniciada a 14/04/96. As primeiras medições consideradas válidas para o trabalho de monitoramento foram iniciadas a 13/06/96, consistindo em leituras das colunas de mercúrio dos tensiômetros 
Quadro 1: Arcabouço dos procedimentos adotados na pesquisa

\begin{tabular}{|c|c|c|}
\hline $\begin{array}{l}\text { ESCOLHADA } \\
\text { AREADAPES- } \\
\text { QUISAE } \\
\text { DOLOCAL.DA } \\
\text { ESTAÇAO }\end{array}$ & \multicolumn{2}{|c|}{$\begin{array}{l}\text { Escolha da área da pesquisa } \\
\text { Coleta de informações preliminares } \\
\text { Escolha do local para a Estação Piloto }\end{array}$} \\
\hline $\begin{array}{l}\text { COLETA } \\
\text { DE DADOSA } \\
\text { PARTIR DA } \\
\text { ESTAÇÄO } \\
\text { PILOTO }\end{array}$ & $\begin{array}{c}\text { NATUREZA } \\
\text { DOS } \\
\text { DADOS }\end{array}$ & $\begin{array}{l}\text { Forma de utilização e estado atual do terreno. } \\
\text { Particularidades geológicas, pedológicas da área de estudo e adjacências. } \\
\text { Hidrodinâmica da zona não saturada } \\
\text { Hidrodinâmica da zona saturada } \\
\text { Hidrogeoquímica: "background" hidroquímico, lixiviação e retenção do contaminante }\end{array}$ \\
\hline $\begin{array}{l}\text { RESULTADOS } \\
\text { DA } \\
\text { PESQUISA: } \\
\text { TABULAÇĀO DE } \\
\text { DADOS } \\
\end{array}$ & \multicolumn{2}{|c|}{$\begin{array}{l}\text { Tabelas e gráficos referentes a dados litológicos e pedológicos. } \\
\text { Perfis do solo e do solo-substrato rochoso. } \\
\text { Tabulação de dados de monitoramento. } \\
\text { Gráficos referentes à hidrodinâmica e à hidrogeoquímica. }\end{array}$} \\
\hline $\begin{array}{l}\text { INTERPRETAÇAO } \\
\text { DOS DADOSE } \\
\text { DISCUSSAOO }\end{array}$ & \multicolumn{2}{|c|}{$\begin{array}{l}\text { Análise e interpretação de dados referentes a propriedades do meio poroso } \\
\text { Interpretação de dados referentes à hidrodinâmica das zonas saturada e não saturada } \\
\text { Correlação da hidrodinâmica e características do solo e do substrato rochoso } \\
\text { Aplicação da estatística aos resultados referentes às características químicas da água amos- } \\
\text { trada nas zonas saturada e não saturadas } \\
\text { Discussão sobre mecanismos de retenção e lixiviação do contaminante } \\
\text { Zoneamento referente à hidrodinâmica em planta e em perfil }\end{array}$} \\
\hline CONCLUSOEES & $\begin{array}{l}\text { Sobre } \\
\text { Sobre }\end{array}$ & $\begin{array}{l}\text { s resultados da pesquisa de acordo com seus objetivos } \\
\text { s métodos empregados na pesquisa }\end{array}$ \\
\hline
\end{tabular}




\subsubsection{Bases Cartográficas Utilizadas}

As bases cartográficas utilizadas foram as seguintes:

- folhas topográficas em escala 1:10.000 e 1:2.000, datadas de 1977, confeccionadas pela TERRAFOTO S.A. para o Departamento de Águas e Esgoto - DAE, de Presidente Prudente;

- folha topográfica em escala 1:2.500, confeccionada pelo Departamento de Cartografia da FCT em 1995, referente à área de propriedade da UNESP, com informações gráficas detalhadas

A integração dos dados possibilita uma análise e avaliação da hidrodinâmica e hidrogeoquímica das zonas não saturada e saturada na área medida em levantamento topográfico no local, com extensão de $32.686,00 \mathrm{~m}^{2}$ (Figura 19). A partir deste levantamento, foi traçado um perfil desta área, com direção $87^{\circ} 43^{\prime} 56^{\prime \prime}$ NE - SW.

\subsubsection{Escolha do Local de Instalação dos Equipamentos}

Trata-se de uma etapa de investigaçäo preliminar, destinada a verificar as condiçōes mais adequadas para a instalação do conjunto principal de aparelhos e a localização do canteiro de escoamento superficial. Consistiu na coleta de informações referentes à profundidade do regolito e à eventual existência de entulhos ocultos, objetos enterrados de modo geral, assim como cavidades no interior do solo cuja dimensão possa comprometer o desenvolvimento da pesquisa. O Quadro 2 associa as informaçőes e os meios de investigaçăo relativos a esta etapa preliminar da pesquisa. 
Quadro 2: Investigação preliminar para escolha do local de instalação dos equipamentos

\begin{tabular}{|c|c|}
\hline Profundidade do regolito & RECURSOS DE INVESTIGACÁO \\
\cline { 1 - 1 } & Perfurações a trado \\
\cline { 1 - 1 } Cavidades de raizes mortas e locas de animais & Investigação com método geofísico: \\
\cline { 1 - 1 } Entulhos não aparentes e objetos enterrados & Ground Penetrating Radar - GPR \\
\hline Cavidades de erosão subterrânea ("piping") & \\
\hline
\end{tabular}

A técnica Ground Penetrating Radar (GPR) emprega um equipamento de investigação eletromagnética, baseada no princípio da propagação de uma onda eletromagnética em um meio qualquer (PORSANI, 1999). Pequenos pulsos de energia eletromagnética são aplicados ao terreno através de antenas que operam em freqüências que podem variar de 10 a $1000 \mathrm{Mhz}$. O sinal transmitido penetra no solo e no substrato rochoso, sendo refletido em horizontes refletores que, por sua vez, dependem de suas propriedades elétricas. A Figura 10 exemplifica um perfil do terreno obtido através do emprego desta técnica, onde são identificados objetos enterrados.

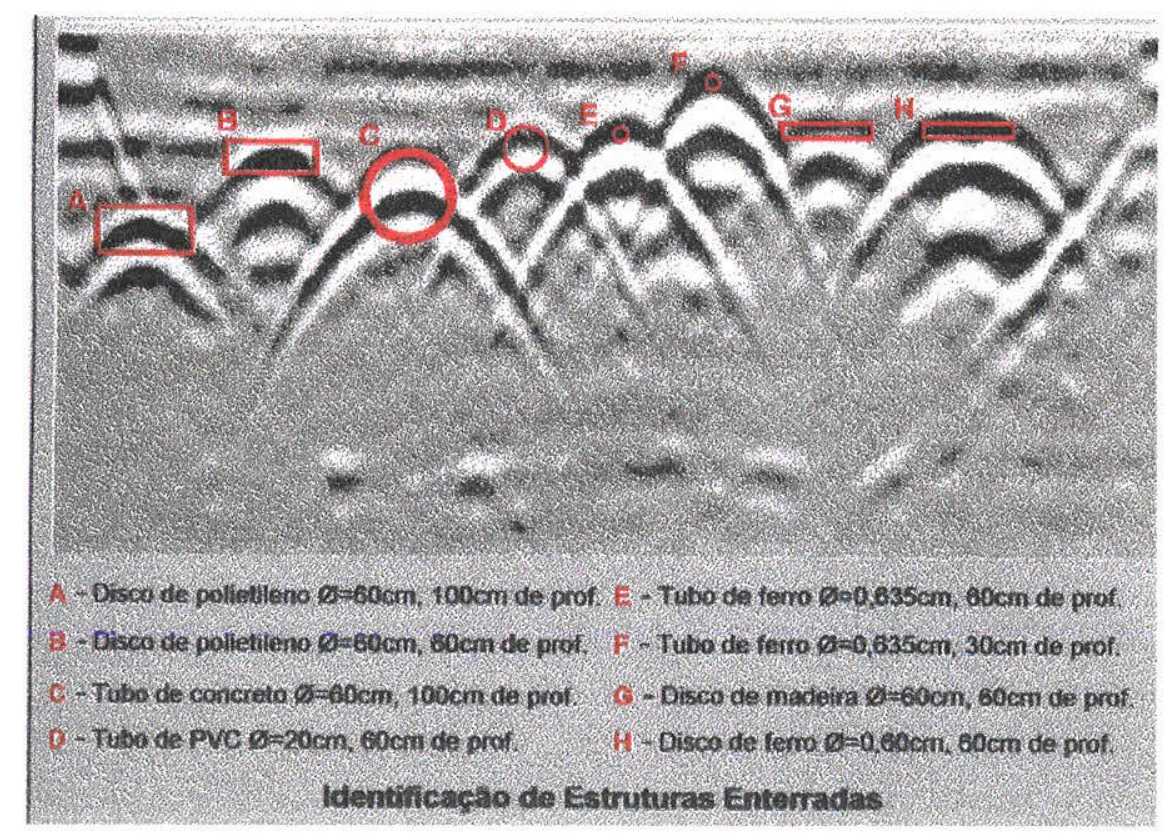

Figura 10: Exemplo de perfil de varredura do método GPR (MARQUES, 1998) 


\subsubsection{Levantamento Geológico e Pedológico de Detalhe}

O Quadro 3 resume o que constitui esta etapa da pesquisa.

Quadro 3: Levantamentos geológico e pedológico de detalhe.

\begin{tabular}{|c|c|c|}
\hline $\begin{array}{c}\text { NATUREZA } \\
\text { DA INFORMAÇÃO }\end{array}$ & RECURSOS DE INFORMAÇÄO & $\begin{array}{c}\text { TIPO DE EQUIPAMENTO E } \\
\text { LABORATÓRIO }\end{array}$ \\
\hline \multirow{2}{*}{$\begin{array}{l}\text { Zoneamento do solo, de regoli- } \\
\text { to e do maciço rochoso } \\
\text { na zona não saturada } \\
\text { e parte da zona saturada }\end{array}$} & $\begin{array}{c}\text { Localização da zona saturada } \\
\text { Descriçăo de amostras de regolito e } \\
\text { do maciço rochoso }\end{array}$ & $\begin{array}{l}\text { Poços de monitoramento } \\
\text { Laboratório de Sedimentologia e }\end{array}$ \\
\hline & $\begin{array}{c}\text { Análise granulométrica e determi- } \\
\text { nação do grau } \\
\text { de cimentação }\end{array}$ & Pedologia - FCT/UNESP \\
\hline \multirow[b]{2}{*}{$\begin{array}{c}\text { Caracterização pedológica do } \\
\text { solo }\end{array}$} & $\begin{array}{l}\text { Descrição morfológica e amostra- } \\
\text { gem do solo }\end{array}$ & $\begin{array}{l}\text { Laboratório de Sedimentologia e } \\
\text { Pedologia - FCT/UNESP }\end{array}$ \\
\hline & $\begin{array}{c}\text { Análise de rotina do solo } \\
\text { Análise com ataque sulfúrico para } \\
\text { determinaçăo de } K_{i} \text { e } K_{r}\end{array}$ & $\begin{array}{l}\text { Laboratório de Solos da } \\
\text { ESALQ/USP } \\
\text { Laboratório de Solos da } \\
\text { ESALQ/USP }\end{array}$ \\
\hline
\end{tabular}

No tocante ao zoneamento em perfil do terreno da área pesquisada, devido ao fato de a zona não saturada atingir, em profundidade, o interior do substrato rochoso, é necessária uma caracterização tanto do material inconsolidado de cobertura quanto de parte do substrato rochoso. A necessidade de combinação de zonas de solo e de rocha num mesmo perfil, assim como a característica de descontinuidade vertical tanto numa zona como na outra, oferecem uma dificuldade inicial no tocante à uniformização de procedimentos. As classificações adotadas em análises morfológicas e a definição de propriedades na Pedologia diferem em geral daquelas empregadas na Sedimentologia. No tocante ao solo, um dos aspectos mais importantes a serem considerados é a textura, referindo-se ela à distribuição granulométrica. De acordo com CUSTODIO \& LLAMAS (1990), não existe um padrăo universal de escala e denomina- 
ções para esta propriedade, considerando mais aceitável a classificação aprovada pelo Departamento de Agricultura dos Estados Unidos - USDA. Para as pesquisas em Sedimentologia, no Brasil é adotada principalmente a classificação granulométrica de Wentworth (SUGUIO, 1980 ). No presente estudo, optou-se pela análise granulométrica baseada em escala aplicada à Pedologia, por já ter sido incorporada à rotina de serviços do Laboratório de Sedimentologia da FCT/UNESP.

A determinação do grau de cimentaçäo é incluída nesta etapa, importando mais para a caracterização do material do substrato rochoso do que para o da cobertura de solo. A identificação de zonas diferenciadas, que caracterizam descontinuidades no substrato rochoso e a compartimentação adotada na representação de perfis servem como referência para as observações de hidrodinâmica a serem efetuadas. Quanto a outras propriedades, os critérios relativos a algumas delas, como densidade, porosidade, capacidade de retenção, podem ser aplicados tanto aos solos como ao substrato rochoso. Por razões de ordem prática e de orientação da pesquisa, elas foram analisadas apenas para os solos.

\subsubsection{Amostragem de rochas e de solos}

A amostragem de rocha e de solo foi orientada para contribuir com informações necessárias para a análise e avaliação de fatores litológicos e pedológicos relacionados à hidrodinâmica e à hidroquímica, principalmente da zona näo saturada.

Para a rocha, foi adotado o critério de variação litológica, cada amostra correspondendo a uma zona ou estrato diferenciado.

O conjunto de amostras em cada local de coleta constitui todo o material retirado na perfuração de um poço ou de uma escavação destinada à instalação de equipamento ou o material referente a todo um canal aberto na parede de uma trincheira. Representa assim continuamente todo o perfil de solo ou de rocha amostrado. Procede-se então a uma trituração e à quarteação de cada amostra destinada às análises físicas e químicas. 


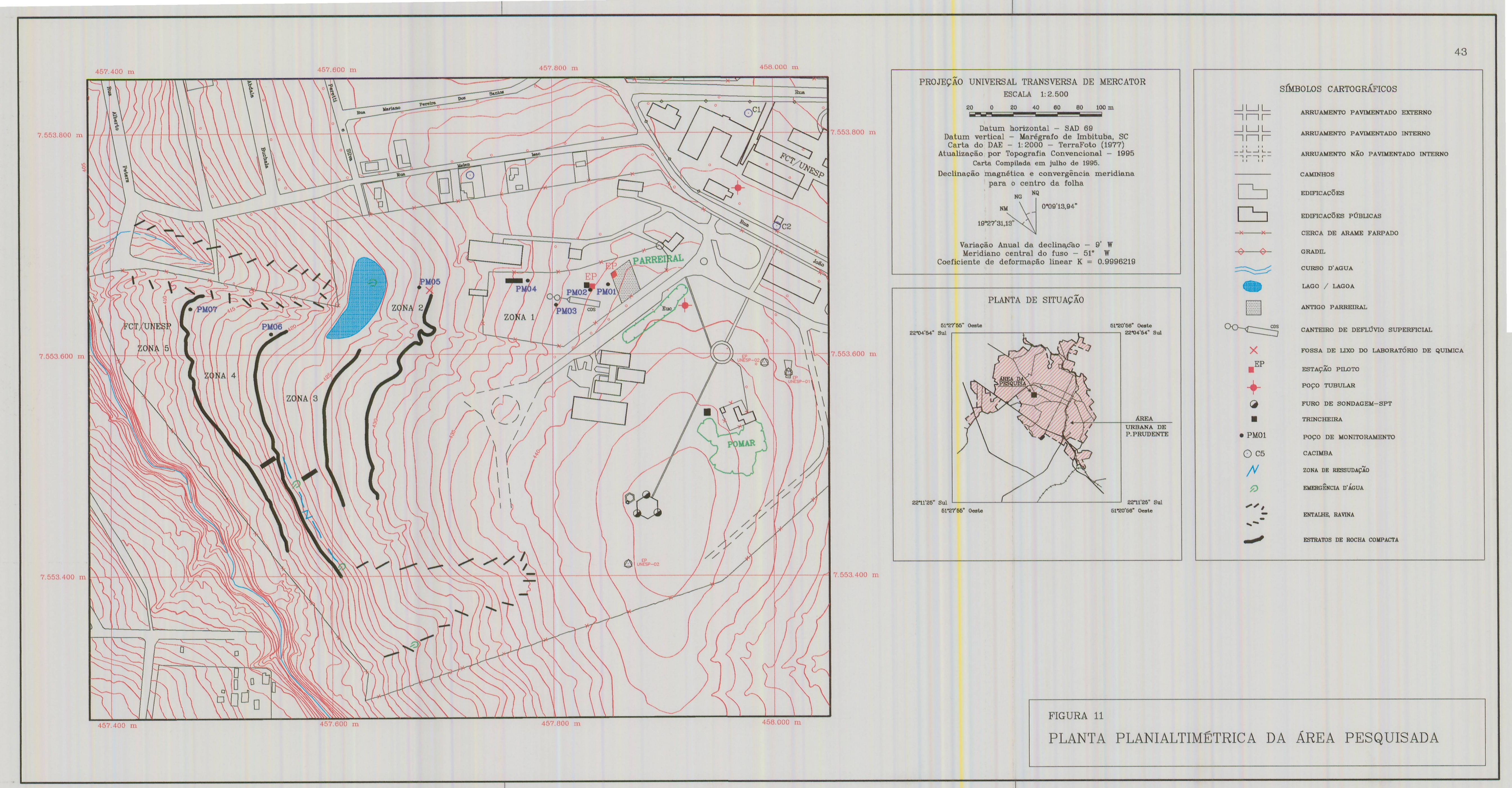


4.9.3.2. Zoneamento do substrato rochoso na zona não saturada

O zoneamento do solo e do substrato rochoso é de preferência representado em forma de perfil geral da área pesquisada, figurando-se a disposição dos horizontes pedológicos e a alternância de estratos mais e menos compactos do arenito associado a lamitos. As rupturas constatadas no perfil da encosta devem corresponder a pelo menos 3 níveis de estratos formados por rocha relativamente mais compacta. Para a determinação do nivel tanto destes estratos como de estratos relativamente menos permeáveis, as perfurações referentes aos poços de monitoramento foram complementadas com amostragem e a coleta de dados relativos à resistência da escavação.

A avaliação por grau de compacidade, importante na identificação de barreiras à percolação, seguiu o critério de classificação comparativa por propriedade mecânica. O recurso adotado para a classificação foi a resistência relativa à escavação.

Quanto à propriedade da cimentação, distinguem-se os cimentos em carbonático e ferruginoso, podendo ser incluído o cimento argiloso nos termos mais areníticos. Para a determinação do cimento total, emprega-se o ataque por ácido cloridrico, em concentração $1 \mathrm{HCl}: 3 \mathrm{H}_{2} \mathrm{O}$ por massa. Como a compactação depende fundamentalmente do cimento carbonático, a sua determinação em porcentagem depende de procedimento executado em porçōes separadas de cada amostra: queima a $900^{\circ} \mathrm{C}$ da amostra seca e triturada; remoção de óxidos e hidróxidos de ferro; queima do material de textura argilosa a $900^{\circ} \mathrm{C}$; determinação de teor de argilominerais e óxidos e hidróxidos através de curvas de perdas por queima apresentadas por BISH \& DUFFY (1990); cálculo da perda de carbonatos por calcinação e conversão $\mathrm{CO}_{2}: \mathrm{Ca} \mathrm{CO}_{3}$.

\subsubsection{Caracterização pedológica do solo}

A utilidade da identificaçăo do solo reside no fato de que as propriedades do solo relacionadas à hidrodinâmica e à hidroquímica dependem das propriedadeschave para a classificaçăo pedológica. O solo, como os demais componentes de um 
ambiente, apresenta particularidades de comportamento em relação a várias propriedades, conforme o local onde está sendo realizada uma pesquisa.

A identificaçăo de um determinado solo é feita através da sua classificação pedológica. Os solos são identificados por meio de uma caracterização quanto a algumas propriedades.

$O$ perfil do solo foi descrito em 4 trincheiras, assim localizadas: junto às instalações da EP (T1); próximo ao poço PM04 (T2); próximo a uma das surgências e a distância de $5 \mathrm{~m}$ a montante de uma das rupturas de declive (T3); em ruptura de declive, junto a outra surgência (T4).

No Laboratório de Sedimentologia da FCT/UNESP, foram realizadas determinaçס̃es referentes às seguintes propriedades:

- análise granulométrica para classificação textural;

- massa específica do solo, equivalendo ao que é denominado também "densidade aparente";

- massa específica de sólidos;

- umidade;

- porosidade.

No Laboratório de Análises de Solo, do Departamento de Ciéncia do Solo da Escola Superior de Agricultura "Luiz de Queiroz"- ESALQ, foram efetuadas análises de macronutrientes e determinação de índices de fertilidade e análises com ataque sulfúrico para determinação dos índices $\mathrm{Kr}$ e Ki. Os índices $\mathrm{Ki}$ e $\mathrm{Kr}$ estäo relacionados ao grau e ao tipo de evolução que sofreu o solo (VIEIRA,1988). Estes índices são calculados simplificadamente por estas fórmulas:

$$
\begin{aligned}
& \mathrm{Ki}=1,7\left(\% \mathrm{SiO}_{2} / \% \mathrm{Al}_{2} \mathrm{O}_{3}\right)(3) e \\
& \mathrm{Kr}=1,7\left[\% \mathrm{SiO}_{2} /\left(\% \mathrm{Al}_{2} \mathrm{O}_{3}+0,6375 \times \% \mathrm{Fe}_{2} \mathrm{O}_{3}\right)\right]
\end{aligned}
$$


4.9.4. Informações sobre a Hidrodinâmica da Zona Não Saturada

No Quadro 4 são resumidas as relações entre propriedades e recursos de investigação referentes a este aspecto.

Além da interdependência de características morfológicas e mineralógicas dos meios porosos e suas propriedades hídricas, a interrelação destas propriedades com fatores climáticos tem de considerada em qualquer estudo hidrogeológico. Os gráficos referentes aos dados dos tensiômetros reúnem informações sobre a pluviosidade e a variação do potencial mátrico do solo, indicando a influência do comportamento das chuvas sobre a umidade do solo a diferentes profundidades, assim como dos intervalos temporais de resposta do solo ao evento de precipitação.

\subsubsection{Dados da estação meteorológica}

Pode ser estabelecida uma relação de variações climáticas, de eventos de precipitação muito abundante e eventos de estiagem com o armazenamento de água no solo. Deve ser analisada, a várias profundidades, a característica da resposta do sistema solo-água em termos de armazenamento, de potencial mátrico e de avanço da frente de molhamento, a episódios de precipitação e a períodos de estiagem. É admitida uma resposta variável quanto a intervalo de tempo destes componentes do sistema, devendo aparecer também uma defasagem diversificada da oscilação do nível freático conforme o local de mediçäo e conforme seja a distribuição das chuvas durante o ano hidrológico.

Quanto aos dados colhidos na estação meteorológica da FCT/UNESP, foram coletados e tabulados os registros referentes aos anos de 1996, 1997 e 1998, dos seguintes elementos meteorológicos:

- temperaturas atmosféricas máximas, minimas e médias,

- umidade relativa do ar,

- pluviosidade,

- evaporação da água. 
Quadro 4 : Aspectos metodológicos da hidrodinâmica da zona não saturada

\begin{tabular}{|c|c|c|}
\hline $\begin{array}{l}\text { NATUREZA DAS } \\
\text { INVESTIGAÇÖES }\end{array}$ & RECURSOS TÉCNICOS & $\begin{array}{l}\text { EQUIPAMENTO DE CAMPO } \\
\text { E LABORATÓRIOS }\end{array}$ \\
\hline $\begin{array}{l}\text { REPOSIÇÃO DE ÁGUA NO } \\
\text { SOLO } \\
\text { BALANÇO HÍDRICO }\end{array}$ & $\begin{array}{c}\text { - Dados climatológicos: } \\
\text {-Medições diárias, cômputos } \\
\text { semanais, mensais e anuais de } \\
\text { precipitação; } \\
\text { temperatura atmosférica } \\
\text { e do solo; } \\
\text { cálculo de evapotranspiração } \\
\text { real }\end{array}$ & $\begin{array}{c}\text { Estação Meteorológica da } \\
\text { FCT/UNESP } \\
\text { Pluviômetros na área da } \\
\text { EP }\end{array}$ \\
\hline $\begin{array}{l}\text { DEFLÚVIO E INFILTRAÇÃO } \\
\text { REDISTRIBUIÇÃO DA ÁGUA } \\
\text { NO SOLO: } \\
\text { CAPACIDADE DE CAMPO, } \\
\text { VARLAÇÃO DA UMDADE DO } \\
\text { SOLO }\end{array}$ & $\begin{array}{l}\text {-Ensaios de infiltração } \\
\text {-Medições de escoamento su- } \\
\text { perficial } \\
\text { - Medições de potencial do solo } \\
\text { - Medições de umidade no solo } \\
\text { - Construção de curvas de retenção } \\
\text { reterente aos horizontes A, B e C; }\end{array}$ & $\begin{array}{c}\text { - Tensiômetros } \\
\text {-Blocos de gesso } \\
\text {-Canteiro de deflúvio } \\
\text { superficial } \\
\text { - Área de inundação } \\
\text { Laboratório de Física de Solos } \\
\text { CENA/USP }\end{array}$ \\
\hline $\begin{array}{l}\text { VARIAÇÕES DO POTENCIAL DO } \\
\text { SOLO NO SEU PERFIL. }\end{array}$ & $\begin{array}{l}\text { - Zoneamento do perfil do solo e do } \\
\text { substrato rochoso e suas correla- } \\
\text { çбes com a hidrodinâmica }\end{array}$ & $\begin{array}{l}\text { Tensiômetros, blocos de gesso } \\
\text { Laboratório de Sedimentologia da } \\
\text { FCT/UNESP }\end{array}$ \\
\hline $\begin{array}{l}\text { PROPRIEDADES FISICAS DO } \\
\text { MEIO POROSO: } \\
\text { DENSIDADE, } \\
\text { POROSIDADE, } \\
\text { RETENÇÃO DE ÁGUA PELO } \\
\text { SOLO. }\end{array}$ & $\begin{array}{l}\text { - Análises de rotina de pedologia; } \\
\text { - Construção de curvas de retenção } \\
\text { referente aos horizontes } \mathrm{A}, \mathrm{B} \text { e C }\end{array}$ & $\begin{array}{l}\text { Laboratório de Sedimentologia - } \\
\text { FCT/UNESP } \\
\text { Laboratório de Física de Solos - } \\
\text { CENAJUSP }\end{array}$ \\
\hline $\begin{array}{l}\text { CONDUTIVIDADE } \\
\text { HIDRAंULICA } \\
\text { DO SOLO }\end{array}$ & $\begin{array}{l}\text { - Determinação no campo da con- } \\
\text { dutividade em estado saturado; } \\
\text { - Ensaio de infiltração; } \\
\text { - Análise da distribuição granulo- } \\
\text { métrica e do grau de cimentação da } \\
\text { rocha; } \\
\text { - Determinação indireta segundo } \\
\text { WISCHMEYER et al (1971) }\end{array}$ & $\begin{array}{l}\text { Laboratório de Sedimentologia - } \\
\text { FCT/UNESP }\end{array}$ \\
\hline
\end{tabular}


O tratamento dos dados incluiu inicialmente o cálculo de evapotranspiração real e a construção de gráficos de balanço hídrico climatológico pelo método de Thontwaithe, conforme é explicado em TUBELIS \& NASCIMENTO (1979).

4.9.4.2. Medidas de potencial de água no solo: tensiômetros

Um tensiômetro consiste num tubo, com uma cápsula porosa na extremidade colocada em contato com o solo onde devem ser medidos os valores da carga de sucção (REICHARDT, 1996). Esse tubo, permanentemente mantido preenchido com água, é ligado a um manômetro. Na pesquisa realizada, são empregados tensiômetros dotados de colunas de mercúrio para a medição, conforme é ilustrado na Figura 12.

Se o solo estiver parcialmente seco, a água é deslocada para fora da cápsula, significando que o potencial da água no interior do tubo é maior que o potencial da água no ponto em que a cápsula está localizada. Dessa forma, a pressão da água no ponto onde está a cápsula é negativa, ou seja, representa um meio com deficiência de água. A pressão no local da cápsula, em termos de carga hidráulica, em tênsiômetros de mercúrio, é calculada a partir da fórmula:

$$
\begin{aligned}
& h=-12,6 \mathrm{H}+h_{1}+h_{2} \quad(5), \\
& \text { onde } \\
& h=\text { potencial mátrico (cm de água), } \\
& H=\text { altura da coluna de mercúrio }(\mathrm{cm}) \\
& h_{1}=\text { desnivel da cuba de mercúrio em relação à superficie do terreno } \\
& h_{2}=\text { profundidade da cápsula porosa em relação à superficie } \\
& \quad \text { do terreno }
\end{aligned}
$$


Os tensiômetros instalados área pesquisada (Fotos 7 e 8), de marca APAGER, são fabricados de modo que, por compensação nas dimensões e alturas de instalação, reduzem o cálculo do potencial mátrico à expressão:

$$
h=-12,6 H(6)
$$

Sendo adotado um determinado valor do potencial do solo como uma das referências para se identificar a condição de capacidade de campo, os valores de potencial mátrico registrados a várias profundidades devem ser comparados a este valor. Dados de leituras dos tensiômetros, por exemplo, ganham importância à medida que sejam analisados com base neste parâmetro de referência.

Na pesquisa, as medições referentes aos tensiômetros foram efetuadas diariamente, às 10:00 $\mathrm{h}$.

Dispondo-se de meio para converter os valores de potencial mátrico em dados de umidade correspondente no solo, a medição diária dos tensiômetros apresenta uma utilidade a mais, que consiste na determinação da variação diária do armazenamento de água no solo a diferentes profundidades. Dispondo-se de informações quantitativas desta variação, é possível analisar o comportamento do solo quanto à redistribuiçäo e à drenagem. Representando-se através do seu perfil as variaçס̃es no avanço da frente de molhamento, pode-se localizar zonas de fluxo preferencial, zonas de retardamento da drenagem, obtendo-se também dados mais realistas sobre o valor de potencial mátrico e de umidade correspondentes à condição de capacidade de campo, à medida que os valores obtidos apontam uma estabilização, tendendo à variação mínima.

Para esta análise do comportamento hídrico do solo com base em leituras diárias, foram selecionadas as leituras de tensiómetros referentes a determinados períodos, devido à dificuldade de tratar o conjunto de dados registrados diariamente durante o desenvolvimento da pesquisa.

Deste modo, foram escolhidos períodos correspondentes a eventos de chuva concentrada, intercalados com periodos de estiagem de mais de 5 a 10 dias. 


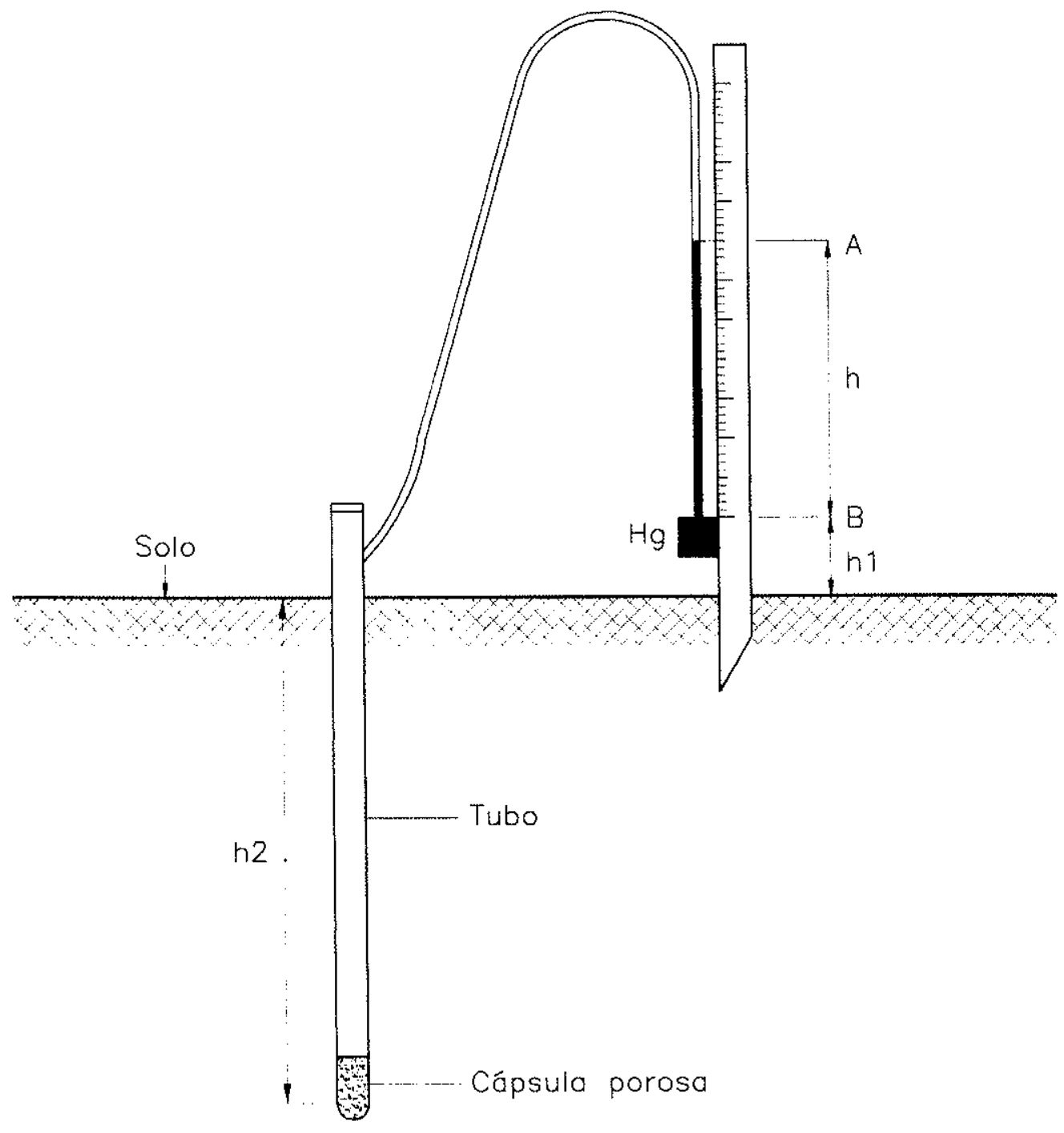

Figura 12 : Esquema do tensiometro com medidor de mercúrio. 
4.9.4.3. Medidas de potencial de água no solo - blocos de gesso

CUSTODIO \& LLAMAS (1986), no Capítulo 6.3 - vol. I, referente à água no solo, inclui a investigação por meio dos blocos, que são envolvidos em material absorvente da umidade, entre os métodos geofísicos, porque relacionam o grau de umidade do meio poroso à resistividade elétrica, a qual é medida através duma ponte de Wheatstone.

Estes sensores são conhecidos tradicionalmente como "blocos de Bouyoucos", por terem sido propostos inicialmente por C. J. Bouyoucos e A. H. Mick ( FOWLER \& LOPUSHINSKI, 1989). São largamente usados na agricultura, para monitoramento do grau de umidade no solo.

Dentre os raros autores que tratam deste tema muito específico, TOLLNER \& MOSS (1985), em referência direta a blocos de gesso, apontam a necessidade de rosição semestral deles no solo. SATRYIO et al (1990) ressaltam as dificuldades na obtenção de medidas confiáveis de umidade tanto com blocos de gesso quanto através de tensiômetros; no entanto, considera os primeiros como mais confiáveis e práticos do que estes últimos. RUPRECHT \& SCHOFIELD (1992), através de pesquisa sobre solos da Austrália, reforçam a idéia de que, para a obtenção de dados confiáveis, os blocos funcionam melhor que os tensiômetros, mas não têm a eficiência da sonda de nêutrons.

A principal vantagem a ser apontada no uso deste tipo de equipamento, tanto para fins de pesquisa aplicada à irrigação, como a estudos de contaminação de água subterrânea, é o seu custo relativamente baixo. Outro aspecto positivo dos blocos de gesso é a sua capacidade de boa resolução no intervalo de potencial matricial entre - 0,06 MPa e-1,5 Mpa (aproximadamente de - 0,60 atm a -15 atm), sendo estes limites muito mais abrangentes do que o intervalo de medição alcançado com tensiômetros (FOWLER \& LOPUCHINSKI, 1989).

No momento de medição, os blocos são conectados, um de cada vez, a este medidor. Os blocos são pré-calibrados, de modo que os valores apresentados pelo medidor sejam convertidos em valores de tensão. Na utilização dos blocos e medidor 


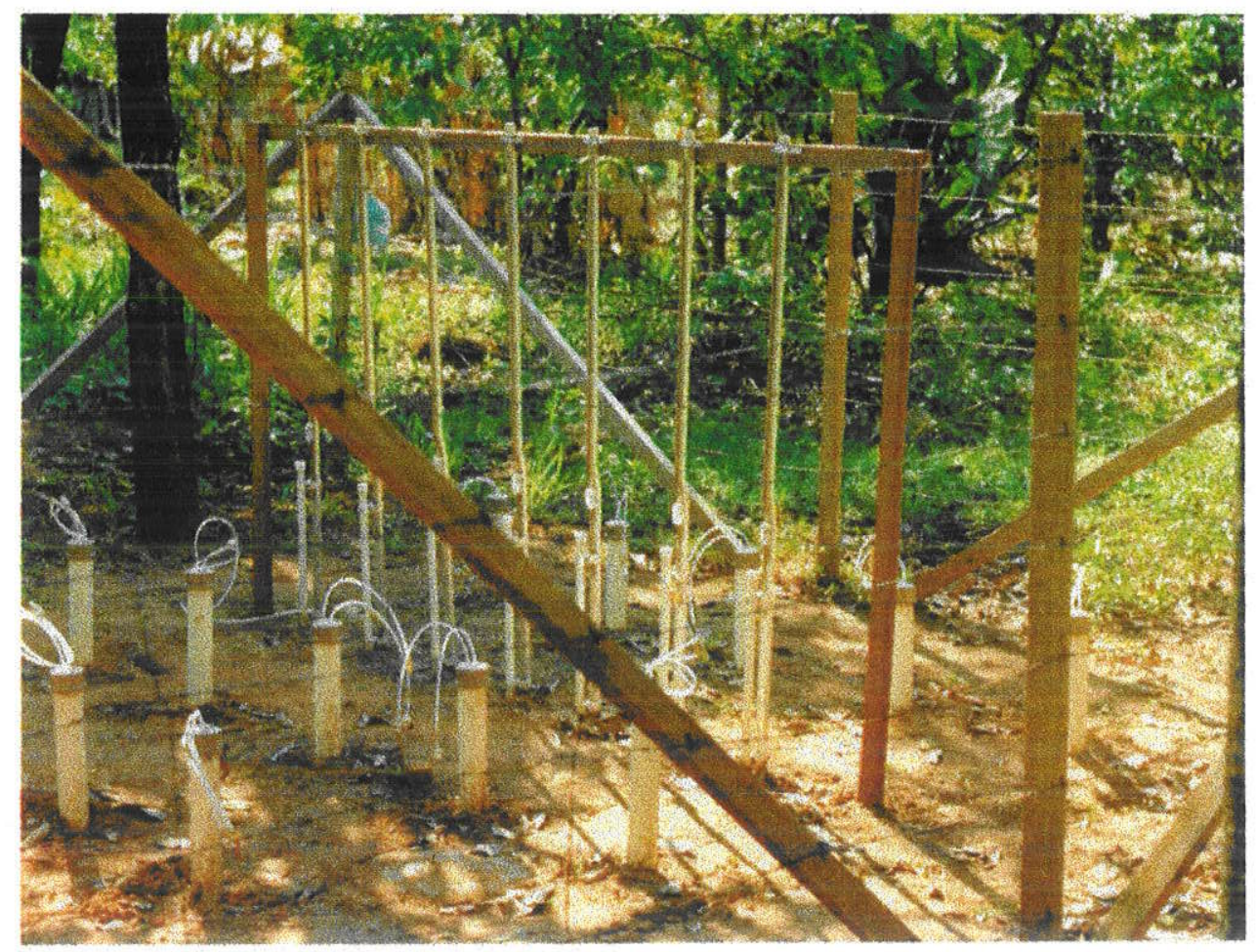

Foto 7: Bateria de tensiômetros e extratores de cápsula porosa

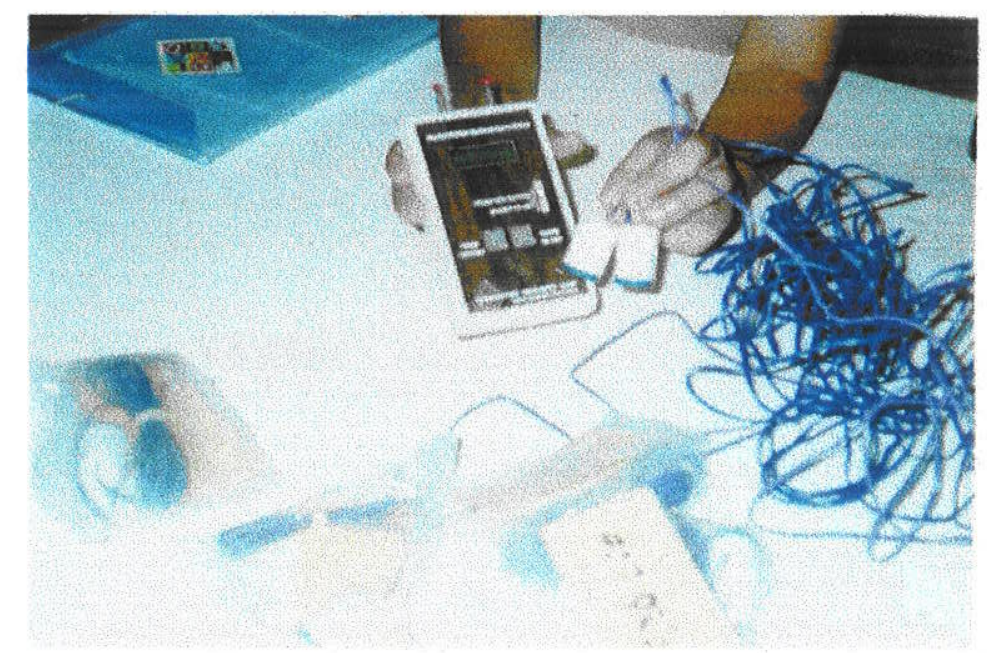

Foto 8: Medidor de potencial mátrico e blocos Soilmoisture 
Soilmoisture, (Foto 8), a conversão de valores de leitura em valores de potencial mátrico é realizada por meio de um ábaco ( Figura 13).

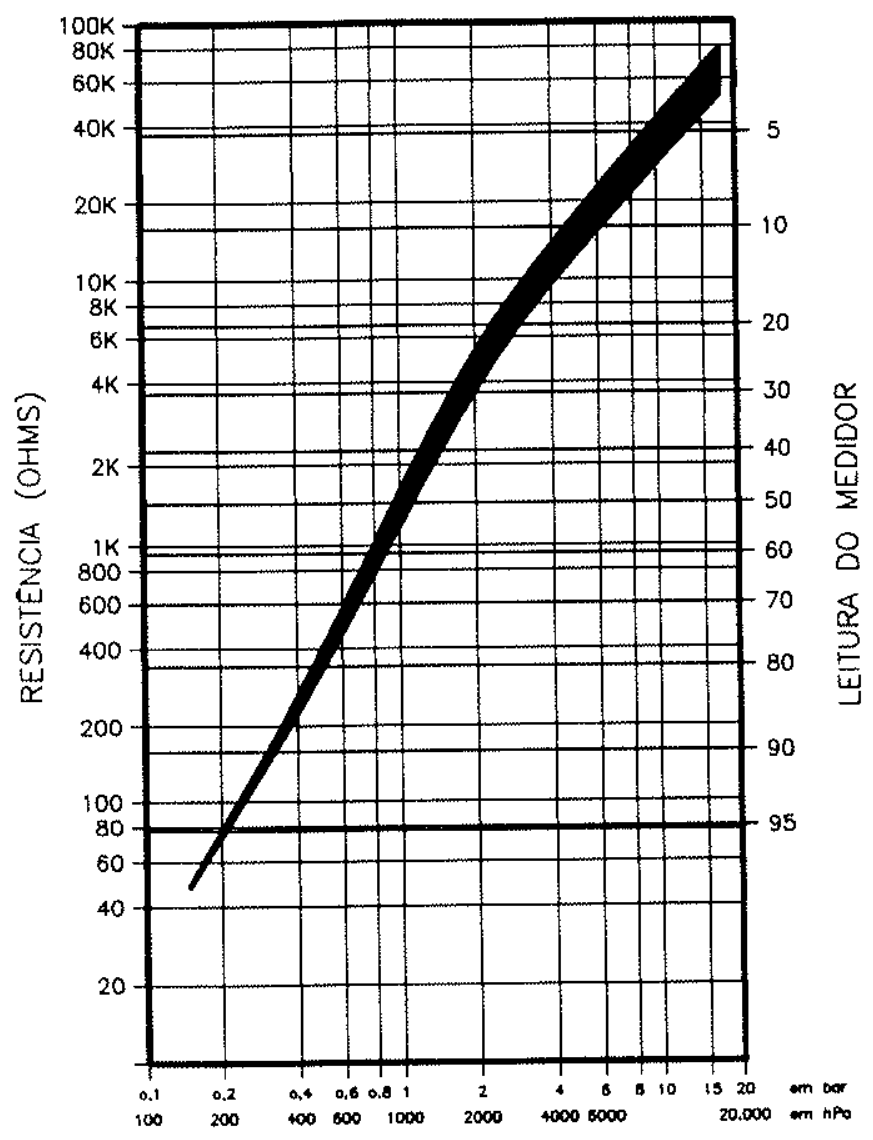

POTENCIAL MÁTRICO

Figura 13: Ábaco para conversão da leitura do medidor de unidade em valor de pressão

(SOILMOISTURE, 1996) 
O emprego deste equipamento complementa a utilizaçäo de tensiômetros. Uma vez construída a curva potencial mátrico $X$ umidade para uma determinada classe de solo, o teor de umidade é estimado com dados do gráfico assim confeccionado.

Em caso de não se dispor dos dados da curva potencial mátrico $X$ umidade, os blocos apresentam uma vantagem em relação aos tensiômetros, que é o da relativa facilidade de serem calibrados no campo ou em laboratório para a conversão de valores de resistência elétrica em valores referentes a umidade, assim propiciando, de modo prático, a construção de curvas resisténcia elétrica $x$ umidade.

A determinação dos valores de tensão matricial com base nas leituras do medidor Soilmoisture é feita através de uma curva de calibração previamente construida e válida para os blocos fornecidos pelo fabricante (Figura 13).

\subsubsection{Ensaio de infiltração}

O estudo da infiltração vertical é classicamente feito inundando-se a superfície do solo com uma lâmina de água de 2 a $10 \mathrm{~cm}$ de altura e mantendo-se esta lamina por adição contínua de água. Esta altura reduzida confere à água um potencial ligeiramente positivo, mas que, na prática, é considerado nulo, considerando-se a infiltração como sendo de potencial nulo.

No campo, um dos meios para se proceder à inundação (Figura 14) consiste em isolar uma área de 9 a $100 \mathrm{~m}^{2}$ por meio de "diques"; outro procedimento emprega dois cilindros concêntricos ( 30 e $60 \mathrm{~cm}$ de diâmetro, aproximadamente), que são encravados no solo e preenchidos de água.

Entende-se por medida da infiltração a medida da velocidade com a qual a água penetra no solo. Ela é denominada de velocidade de infiltração $v_{i}$. Sua definição é idêntica à definição de fluxo de água $q$, da equação de Darcy, sendo então o volume de água $\left(\mathrm{cm}^{3}\right)$ infiltrado por unidade de área $\left(\mathrm{cm}^{2}\right)$ no intervalo de tempo (seg), em termos de $\mathrm{cm} / \mathrm{s}$. Dependendo da aplicação do ensaio, outras unidades podem ser adotadas, como $\mathrm{mm} / \mathrm{seg}, \mathrm{cm} / \mathrm{h}, \mathrm{m} / \mathrm{seg}$ ou $\mathrm{m} / \mathrm{dia}$. 


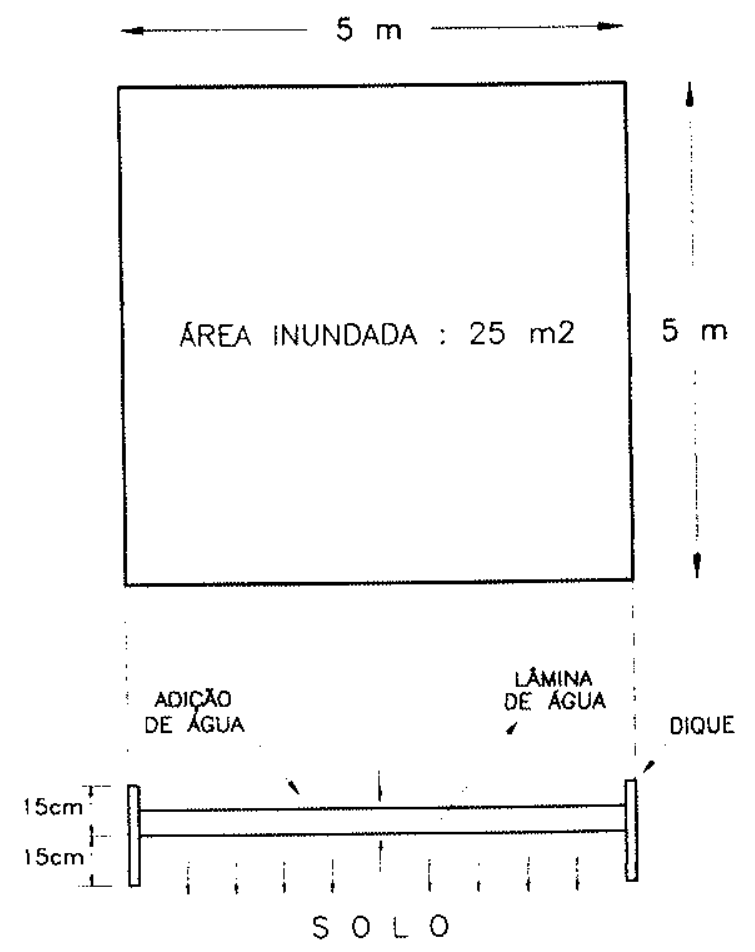

a) AREA INUNDADA

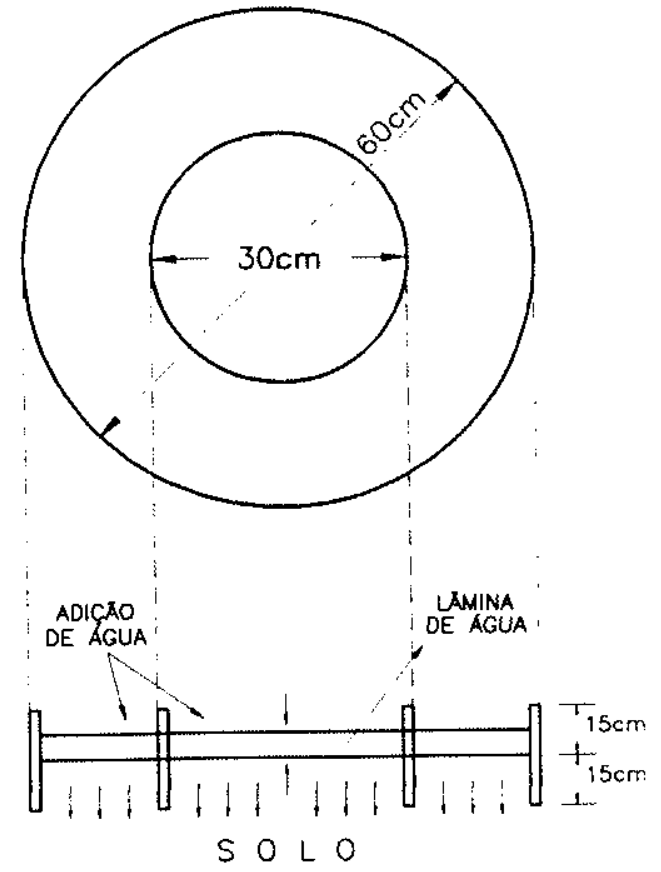

b) INFILTROMETRO DE ANEL.

Figura 14 : Esquema duas técnicas adotadas para ensaio de infiltraçðo

(REICHARDT , 1990)

Se o nível de água dentro de um cilindro utilizado para medir $v_{i}$ é dado pela altura $\mathrm{H}_{\mathrm{i}}$ no instante $\mathrm{t}_{1}$ e $\mathrm{H}_{2}$ em $\mathrm{t}_{2}$, tem-se:

$$
v_{1}=\left(H,-H_{2}\right) /\left(t_{2}-t\right)
$$

Observa-se que $v_{i}$ é grande no início da infiltração e vai diminuindo com o tempo. Verifica-se que, num intervalo de tempo, variável conforme as propriedades do solo, a velocidade de infiltração se estabiliza, assumindo valor constante, denominado infilitração básica $\left(K_{0}\right)$.

Como já foi referido, $v_{i}$ é o próprio $q$ da equaçäo de Darcy, podendo ser expresso como:

$$
\text { vi }=K(\theta) \operatorname{grad} \psi
$$


Uma vez estando saturado o perfil do solo, o potencial mátrico é nulo, podendo na prática ser desprezada a atuação do potencial de pressão, restringindo-se então o potencial ao componente gravitacional, resultando o gradiente $\psi=1$.

Pelo fato de a condutividade $K(0)$ em estado de saturação total corresponder ao índice de condutividade hidráulica, esta propriedade pode ser avaliada pelo menos no horizonte menos profundo do solo.

Uma das aplicações do ensaio de infiltração è a localização de zonas menos permeáveis no perfil de solo, que funcionam como barreira temporária à percolação e contribuem para a existência de fluxo lateral. Em pesquisa realizada em área de erosão acelerada no Município de Bauru/SP, SALOMÃO (1994) empregou este ensaio para a caracterização de impedimento vertical no horizonte $B$ textural de solo identificado dentro da categoria dos podzólicos. A inundação realizada através de um infiltrômetro e o emprego de corante possibilitou o reconhecimento nítido desta barreira.

$\mathrm{Na}$ pesquisa realizada, optou-se por dimensionar a área de inundação a um quadrado de $2 \mathrm{~m} \times 2 \mathrm{~m}$. As finalidades do ensaio eram:

- estimar a condutividade hidráulica do horizonte eluvial ("A") e dos horizontes "B" do solo;

- identificar barreiras ao fluxo vertical da água e a tendéncia ao escoamento lateral dentro do solo.

Para estas finalidades, optou-se por manter a inundação em lâmina d'água de apenas $3 \mathrm{~cm}$ de altura por um período de no mínimo 10 horas.

No procedimento adotado, foi introduzida a amostragem através de 6 furos localizados dentro da área inundada e 2 furos distantes de $0,6 \mathrm{~m}$, no sentido do declive do terreno, de um dos seus limites ( Foto 9). Os furos são revestidos com tubos de PVC em toda a sua profundidade, permanecendo aberta a extremidade inferior deste revestimento.

As profundidades dos 6 furos locados na área a ser inundada são:

$$
0,2 \mathrm{~m}, \quad 0,4 \mathrm{~m}, \quad 0,6 \mathrm{~m}, 0,8 \mathrm{~m}, 1 \mathrm{~m} \text { e } 1,5 \mathrm{~m}
$$


As profundidades dos furos externos à área a ser inundada são:

$$
0,6 \mathrm{me} 1 \mathrm{~m} \text {. }
$$

A amostragem nos furos foi realizada ao término da perfuração, no decorrer e depois do ensaio de inundação e no dia seguinte ao da inundação. Utilizou-se a retirada de amostras com o uso intercalado de trado de $5 \mathrm{~cm}$ e $7,5 \mathrm{~cm}$ de diâmetro, para evitar diferenças maiores que $5 \mathrm{~cm}$ de níveis de amostra num mesmo furo.

A etapa final do experimento consistiu na abertura de uma trincheira de $2 \mathrm{~m}$ de comprimento, $1 \mathrm{~m}$ de largura e 1,80 $\mathrm{m}$ de profundidade, localizada de modo a garantir a melhor correspondência possivel de posição com a amostragem efetuada nos furos. Uma terceira etapa de amostragem foi cumprida através da coleta de amostras indeformadas na trincheira, com intervalos de $0,20 \mathrm{~m}$ de profundidades das amostras.

O total de unidades de amostragem foi de 58 , das quais 20 são indeformadas. Destas últimas, 6 procederam de zonas de solo adjacente a raízes.

Foi aplicado o método gravimétrico para determinação de umidade e de sua variação ao longo e após o decorrer do ensaio de inundação.

Para se analisar o avanço da frente de molhamento, os valores de umidade por volume foram primeiramente calculados com base na coleta de amostras indeformadas, que foi efetuada no terceiro dia do ensaio. Os valores de massa específica dos sólidos $\left(\rho_{s}\right)$, massa específica do solo $(\rho)$, porosidade do solo $(\alpha)$ e umidade em volume $(\theta)$, referentes a cada uma das unidades de amostragem foram calculados de acordo com estas fórmulas:

$$
\begin{aligned}
& \rho_{s}=m_{s} N_{s}\left(g / \mathrm{cm}^{3}\right)(9) \text {, sendo } \\
& \mathrm{m}_{\mathrm{s}}=\text { massa de sólidos } \mathrm{e} \\
& V_{3}=\text { volume de sólidos } \\
& \rho=m_{8} N\left(g / \mathrm{cm}^{3}\right)(10), \text { sendo } \\
& V=\text { volume do solo; }
\end{aligned}
$$




$$
\begin{gathered}
\alpha=\left(V-V_{s}\right) N \quad\left(\mathrm{~cm}^{3} / \mathrm{cm}^{3}\right)(11), \text { sendo } \\
V=\text { volume do solo na amostra indeformada } \\
\theta \%=\left(V_{a} N\right) .100(12), \text { sendo } \\
V_{a}=\text { volume de água contida no solo. }
\end{gathered}
$$

A determinação da umidade por volume a partir das amostras deformadas foi possibilitada por cálculos de conversão, segundo as fórmulas :

$$
\begin{aligned}
& V_{\text {sol }}=M s / \rho_{\text {sol }} \\
& \text { e } \quad V=V_{\text {sol }} / \alpha
\end{aligned}
$$

Uma vez encerrado o ensaio de infiltração e a última amostragem, os perfurações utilizadas para amostragem de solo foram reservadas para a execução de ensaios de condutividade hidráulica. O procedimento incluiu o aprofundamento dos furos por mais $0,5 \mathrm{~m}$ ou mais abaixo do revestimento, procedendo-se também à uniformização do diámetro nesse trecho final. O procedimento escolhido para esses ensaios é o de infiltração em perfurações, conforme orientação da ABGE (1996). Infelizmente estes ensaios não puderam ser efetivados, devido à dificuldade de manter o solo em estado de saturação de água.

4.9.4.5. Determinações de laboratório - correlação umidade $x$ potencial mátrico e curva de retenção

A curva de retenção relaciona o potencial do solo com a umidade (LIBARDI,1995). O solo, em amostra indeformada e com um volume conhecido, $\hat{\theta}$ 
saturado e submetido a pressões de valores estabelecidos de acordo com uma escala ascendente. A aplicação de uma determinada carga é suficiente para neutralizar o potencial de retenção do solo pressão até um grau que se traduz na umidade mantida por este solo. A cada valor de carga aplicada, corresponde um valor de umidade. Plotando - se os dife rentes valores de umidade e de carga aplicada, constrói - se a curva característica de um determinado horizonte de um solo.

Na pesquisa realizada, as amostras escolhidas para esta finalidade foram 6 , referentes a 3 dos horizontes mais característicos do perfil descrito na Trincheira 1 . As determinações foram efetuadas através do método da Câmara de Richards no Laboratório de Física de Solos do Centro de Energia Nuclear na Agricultura - CENAUSP, em Piracicaba/SP.

4.9.4.6. Medida do escoamento superficial

A medição do escoamento superficial é realizada por meio de um canteiro por onde somente pode escoar a água da chuva que atinge a superfície da área previamente delimitada (Figura 15).

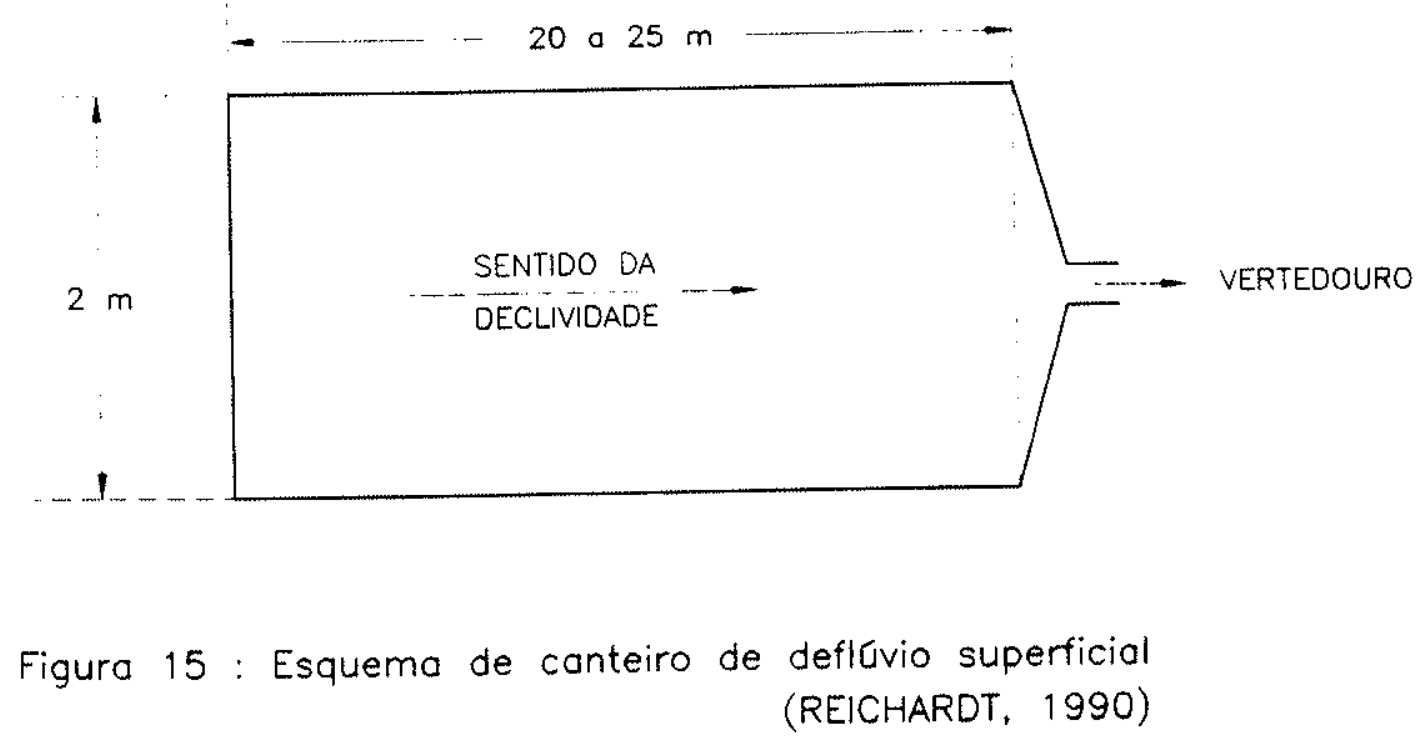

Havendo declividade diferente de zero na superfície do terreno, teoricamente pode haver escoamento superficial. Para medida do deflúvio superficial, pode ser 
adotada a unidade de milímetro, que é empregada para medição do armazenamento de água pelo solo, da pluviosidade, da infiltração acumulada, da evapotranspiração e da absorção de água pelas raízes. Por conveniência, os valores são convertidos em unidades de litro, uma vez que $1 \mathrm{~mm}$ de precipitação medido no pluviômetro significa $1 \mathrm{~L} / \mathrm{m}^{2}$ de chuva que atinge a superfície do terreno. Em princípio, a medição é simples, se for medido o volume $V$ de água que escoa e sai de uma área de dimensões conhecidas.

A área A é delimitada por meio de "diques" (tábua, alvenaria, folha metálica ou mesmo solo) e, na parte inferior, deve ser instalado um dispositivo para a coleta do volume $\mathrm{V}$ de água saída da área assim isolada.

$O$ canteiro de escoamento superficial que foi instalado na E P mede $25 \mathrm{~m}$ por $2 \mathrm{~m}$ (Foto 9), com o seu comprimento orientado na direção de maior declive do terreno. É dotado de vertedouro, conduto de água e 2 tambores para coleta e medição de volume de água. Ao longo do canteiro, uma série de 12 pluviômetros, apropriados à coleta de chuva interceptada, mede a precipitação local.

A precipitação restrita à parcela é calculada com base a média das medidas dos pluviômetros. Multiplicando-se este valor médio pela área da parcela isolada, obtém-se o valor da precipitação que atinge nesta área. A parcela que escoou é coletada num primeiro tambor até a altura máxima de $28 \mathrm{~cm}$. Em caso de ser ultrapassado este limite de altura, o excesso de água coletada neste primeiro tambor escoa por 7 saidas, sendo apenas uma delas dotada de comunicação com o segundo tambor. 0 total da parcela de escoamento é calculado pela seguinte expressão:

$$
V=\pi \cdot R^{2} \cdot\left(H_{1}+7 H_{2}\right) \quad(15)
$$

sendo:

$$
\begin{aligned}
& V=\text { volume da água que escoa superficialmente (em l) } \\
& R=\text { raio dos tambores (de } 17 \mathrm{~cm} \text { ou } 1,7 \mathrm{dm} \text { na área da pesquisa), } \\
& H_{1}=\text { altura medida no primeiro tambor (em } \mathrm{cm} \text { e em dm) e } \\
& H_{2}=\text { altura medida no segundo tambor (em } \mathrm{cm} \text { e em dm) }
\end{aligned}
$$




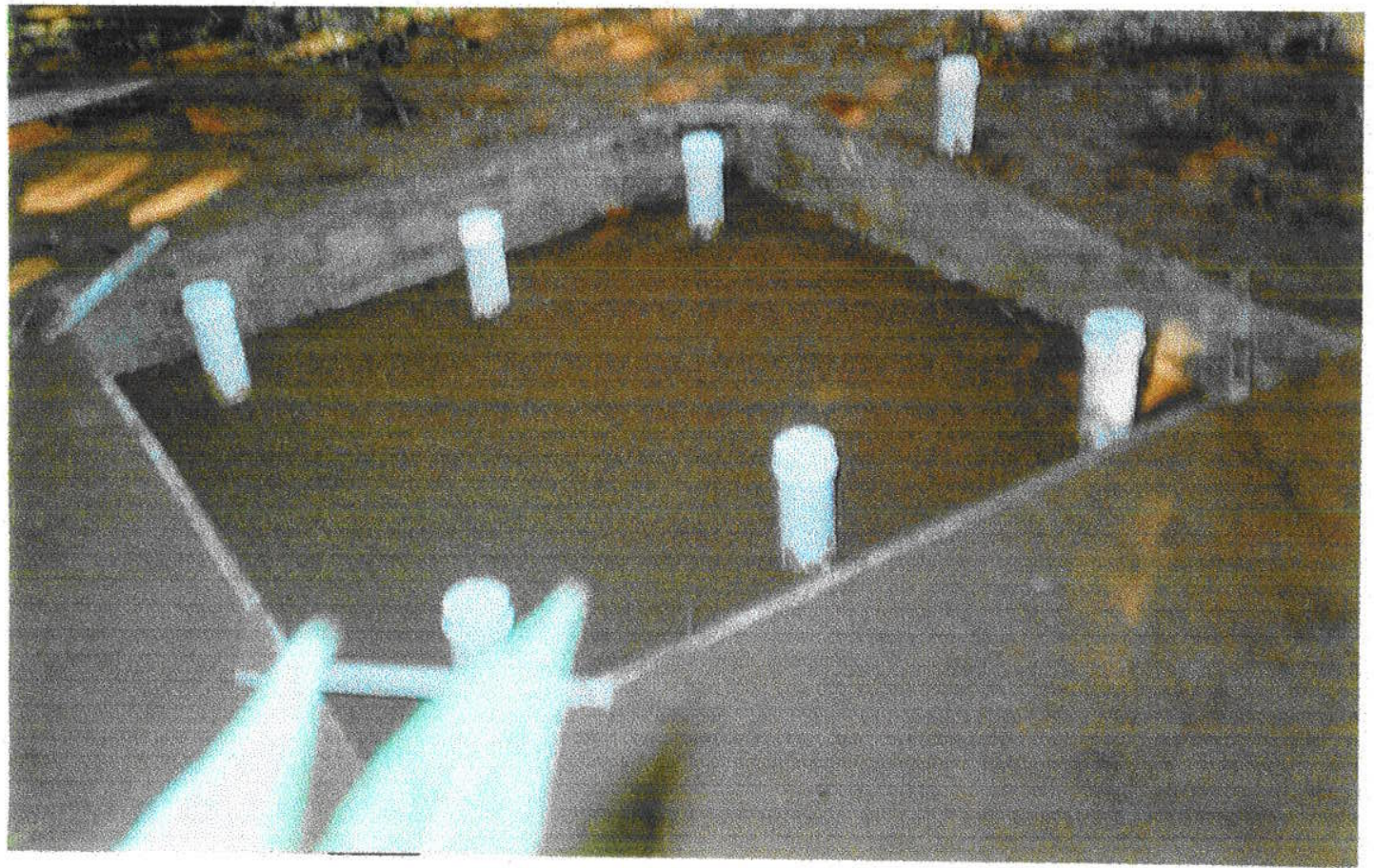

Foto 9: Área destinada ao ensaio de infiltração

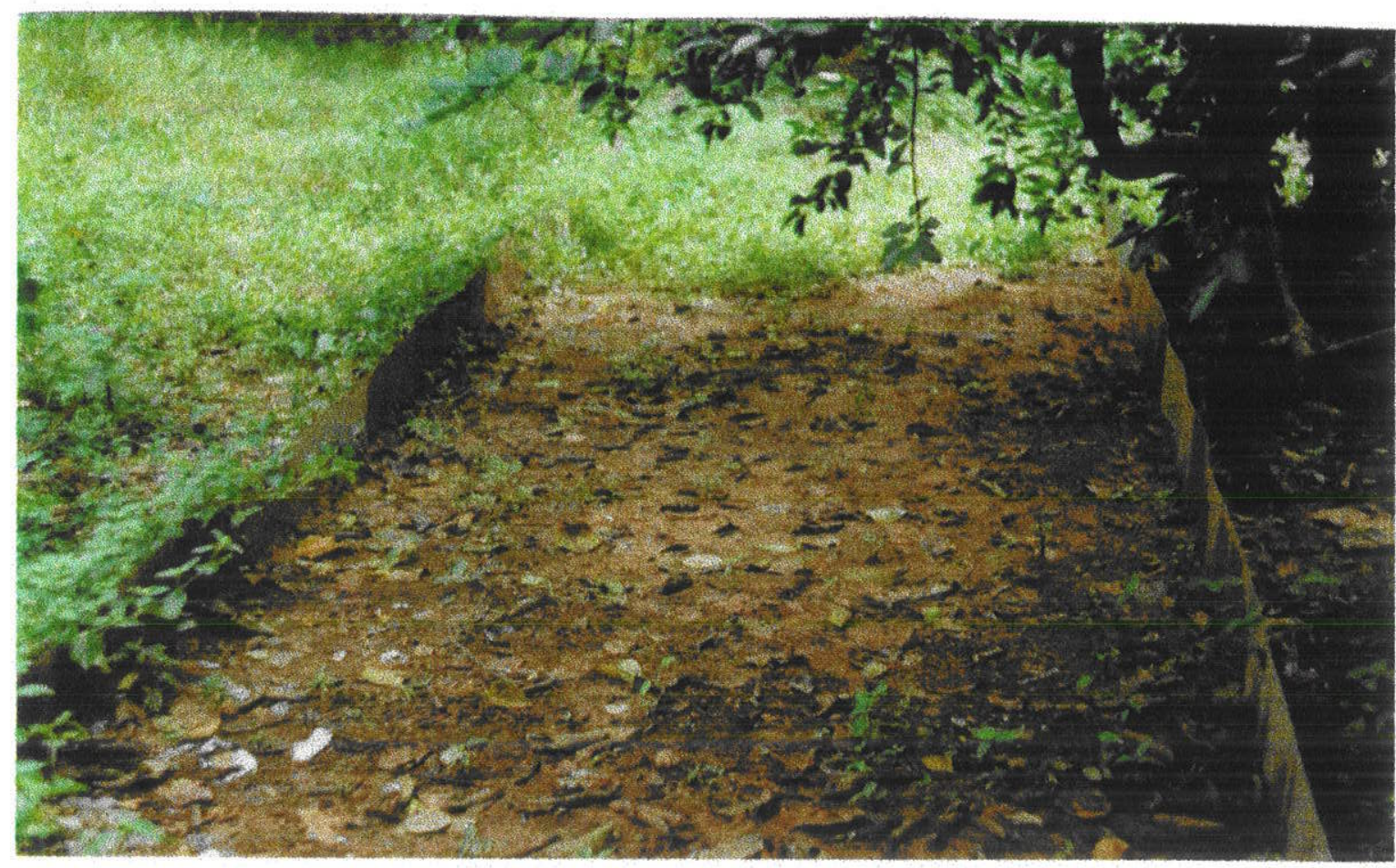

Foto 10: Canteiro de deflúvio superficial em instalaçăo 
4.9.4.7. Classificação do meio poroso relacionada à condutividade hidráulica

Existem diferentes proposições de classificação de solo com referência à condutividade hidráulica de acordo com as propriedades morfológicas e de classificação da rocha pela distribuição granulométrica e pelo grau de compactação natural. Dentre as classificações mais práticas, está a de WISCHMEIER et al (1971), que é a adotada na presente pesquisa. Esta escala estabelece correlações entre a condutividade hidráulica e a propriedade de estrutura do solo, de acordo com critérios qualitativos. Uma vez que esta é uma propriedade-chave na classificação pedológica, a cada categoria de solo pode ser atribuído um dos valores estabelecidos na escala. No caso de classede solo bem diferenciada verticalmente, como a dos podzólicos, identificada na área de estudo, esta classificação é aplicada a cada horizonte do solo.

Em ordem decrescente, a condutividade hidráulica é função de:
a) estrutura
b) massa específica seca
c) textura

Dentro da escala de dependência da estrutura, os extremos de maior e menor influência correspondem, respectivamente ao tipo laminar e ao granular bem definido, gräos relativamente grandes e bem arredondados. No caso de horizontes iluviais de solos podzólicos, geralmente a estrutura de prismas grandes e bem angulares dificulta a drenagem pelo perfil.

4.9.5. Informações sobre a Hidrodinåmica da Zona Saturada

No Quadro 5 estão resumidas as relaçס̃es entre dados necessários e recursos de investigaçăo no tocante a este aspecto. 
Quadro 5: Aspectos metodológicos da hidrodinâmica da zona saturada

\begin{tabular}{|c|c|c|}
\hline $\begin{array}{l}\text { NATUREZA DA } \\
\text { INFORMACÄO }\end{array}$ & $\begin{array}{l}\text { INFORMAÇÕES } \\
\text { UTILIZADAS }\end{array}$ & $\begin{array}{l}\text { RECURSOS DE } \\
\text { INVESTIGACÄO }\end{array}$ \\
\hline $\begin{array}{l}\text { ARACTERISTICAS DE } \\
\text { RECARGA }\end{array}$ & $\begin{array}{l}\text {-Dados de precipitação pluvial } \\
\text { - Medições do nivel do aquífero } \\
\text { livre } \\
\text { - Drenagem na zona não saturada } \\
\text {-Ensaios de infiltração } \\
\text {-Mediçães de deflúvio } \\
\text { - Correlação precipitação pluvial x } \\
\text { oscilação do nível freático }\end{array}$ & $\begin{array}{c}\text { Estação Meteorológica da } \\
\text { FCT/UNESP } \\
\text { - Pluviômetros na área da EP } \\
\text { - Medidor de nível d'água Altronic } \\
\text { - Tensiômetros }\end{array}$ \\
\hline $\begin{array}{l}\text { NTAÇÃO DO FLUXO } \\
\text { D'ÁGUA }\end{array}$ & $\begin{array}{l}\text { - Superfície potenciométrica } \\
\text { - Localizaçăo de descontinuidades } \\
\text { e possiveis barreiras } \\
\text { - Traçadores quimicos }\end{array}$ & $\begin{array}{l}\text { - Poços de monitoramento } \\
\text { - Cacimbas } \\
\text { Laboratório de Sedimentologia - } \\
\text { FCT/UNESP }\end{array}$ \\
\hline $\begin{array}{c}\text { VELOCIDADE DO FLUXO } \\
\text { D'ÁGUA }\end{array}$ & - Traçadores químicos & $\begin{array}{l}\text { - Laboratório de Hidroquímica - } \\
\text { CAS/IGUSP } \\
\text { - Laboratório de Análises Quimicas } \\
\text { da CETESB }\end{array}$ \\
\hline
\end{tabular}

\section{9.5.1. Dados climatológicos para a recarga}

O balanço hídrico é importante em avaliações referentes à recarga de aqüíferos. O balanço hídrico trata do excesso ou a escassez de água no solo ou mais propriamente a taxa de infiltração da água pluvial. $O$ balanço hídrico real exige cálculos de infiltração com base em dados da hidrodinâmica do solo e cálculos referentes à atuação das plantas, sendo mais preciso que o balanço climatológico.

Havendo condições de drenagem no perfil do solo e por toda a zona não saturada, devido ao excedente de água de infiltração, haverá condiçōes para a recarga periódica. A variação do nivel do aqüífero livre depende do balanço hídrico anual, pelo qual se avalia a influência das variaç̋̋es sazonais de precipitação sobre a recarga. Sob este aspecto, o comportamento da pluviosidade é uma característica importante, como tem sido reconhecido em numerosos estudos sobre a correlação entre a chuva acumulada $\theta$ a oscilaçăo do nivel freático. 
4.9.5.2. Medições do nivel freático

A oscilação do nível freático foi medida em 7 poços de monitoramento e 2 cacimbas. Nos anos de 1994 e 1995, medições foram efetuadas em 3 cacimbas do Campus da FCT/UNESP e 2 outras nas suas redondezas. Posteriormente, as cacimbas $\mathrm{C}_{1}$ e $\mathrm{C} 2$ foram incluídas no monitoramento próprio da pesquisa.

A instalação dos poços foi efetuada de acordo com as recomendações da CETESB ( 1986). Os poços foram perfurados com trado manual e trépano. Neles são instalados tubos de PVC, cujos diâmetros externos medem $8 \mathrm{~cm}$ nos poços PM01, PM02 e PM03, PM06 e PM07 e 5,5cm nos poços PM04 e PM05, com um trecho final de 1,50 m ranhurado e envolvido por uma tela de nylon. O espaço livre entre os tubos e as paredes do furo é preenchido, na zona de filtragem da água, por um pré-filtro de areia lavada e acima desta, por material removido na perfuração e por um colar de bentonita.

Com um medidor Altronic, em cada ponto de monitoramento, foi medida periodicamente a profundidade do topo da zona saturada. Os valores de profundidade foram convertidos em valores de nível. As Fotos 11 e 12 referem-se à instalação dos poços de monitoramento e a operação de medição.

O poço PM02 foi instalado dentro da EP. Próximo a esta foram locados os poços PM01, PM03 e PM04. Os poços PM05 e PM06 foram instalados a meia-encosta e o poço PM07, no terço inferior da encosta, conforme se confere nas Figuras 11 e 19.

Uma das finalidades da instalação de 7 unidades de medição do nivel da zona saturada é conhecer o seu comportamento espacial através do terreno de uma encosta onde foi realizada a pesquisa. Deste modo, são colhidas informações básicas sobre a variação do seu nível através de um periodo de vários meses, a atuação da recarga e o condicionamento da água subterrânea a fatores de natureza estrutural ou litológica. Com os dados dos poços e cacimbas monitorados e as informações prévias de cacimbas dentro da área do Campus e das redondezas, foram traçadas curvas representativas do nível freático médio da área pesquisada, resultando em esboço de mapa potenciométrico. 


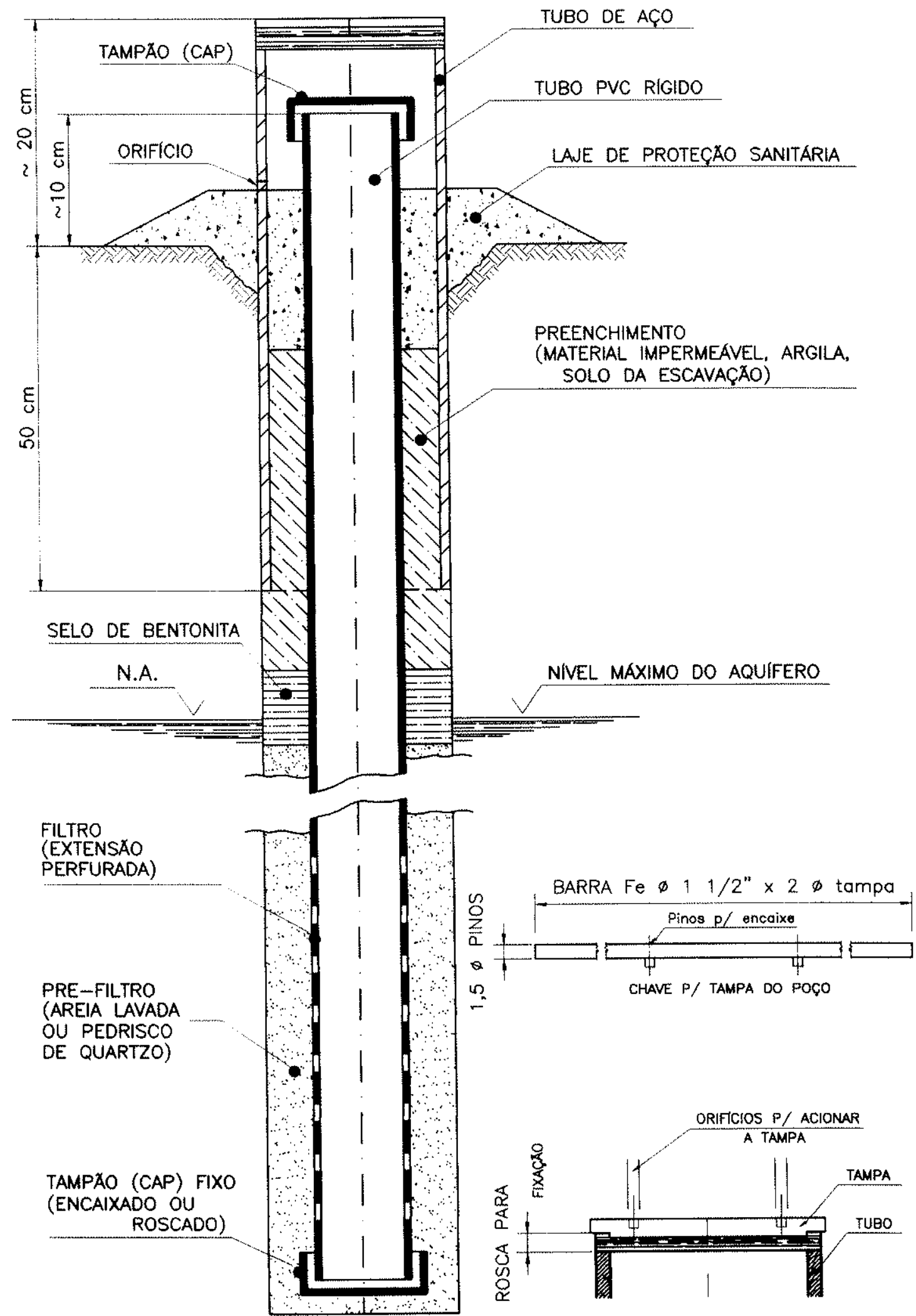

Figura 16 : Perfil esquemático de poço de monitoramento (CETESB, 1986) 


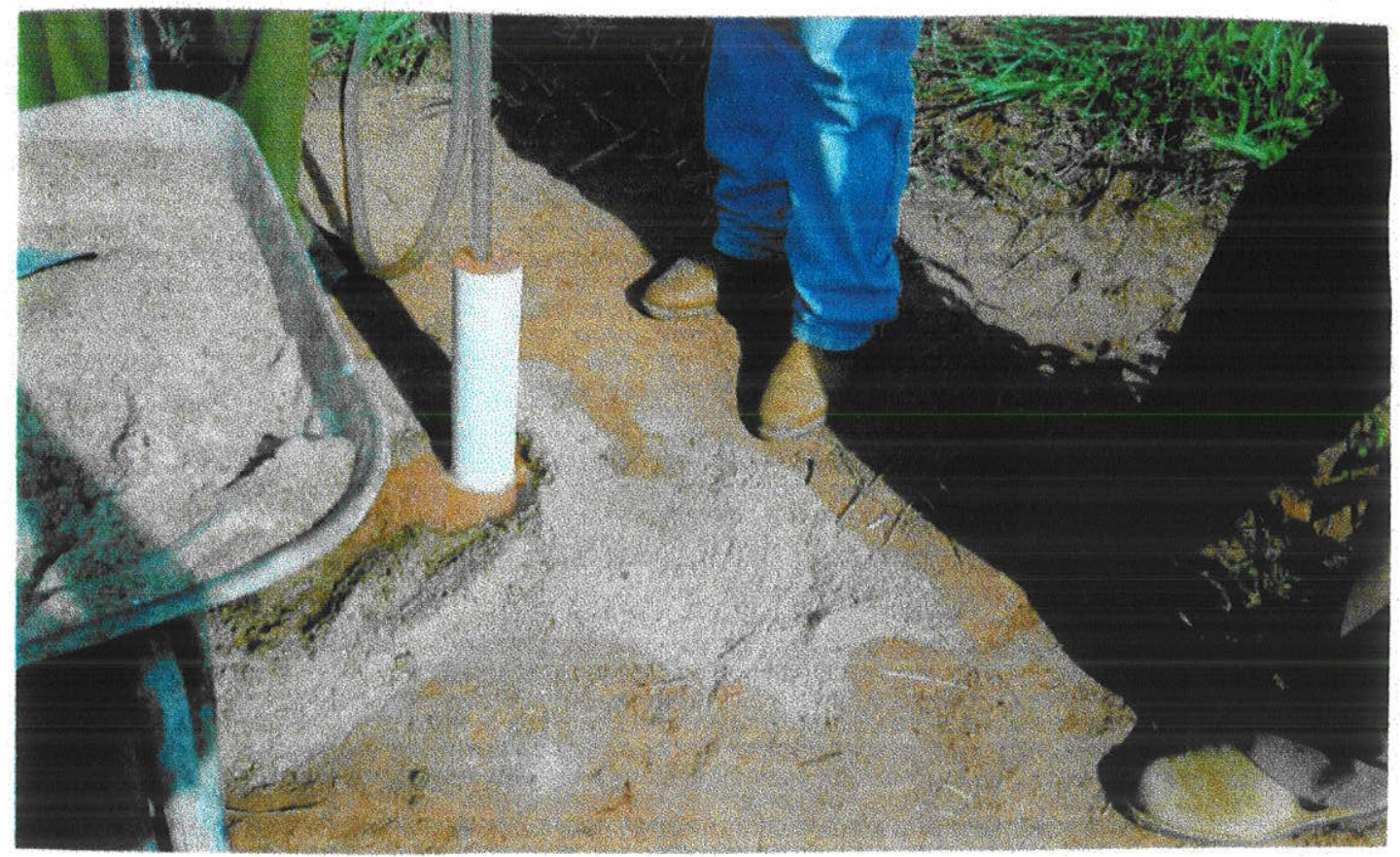

Foto 11: Detalhe da instalação de um poço de monitoramento

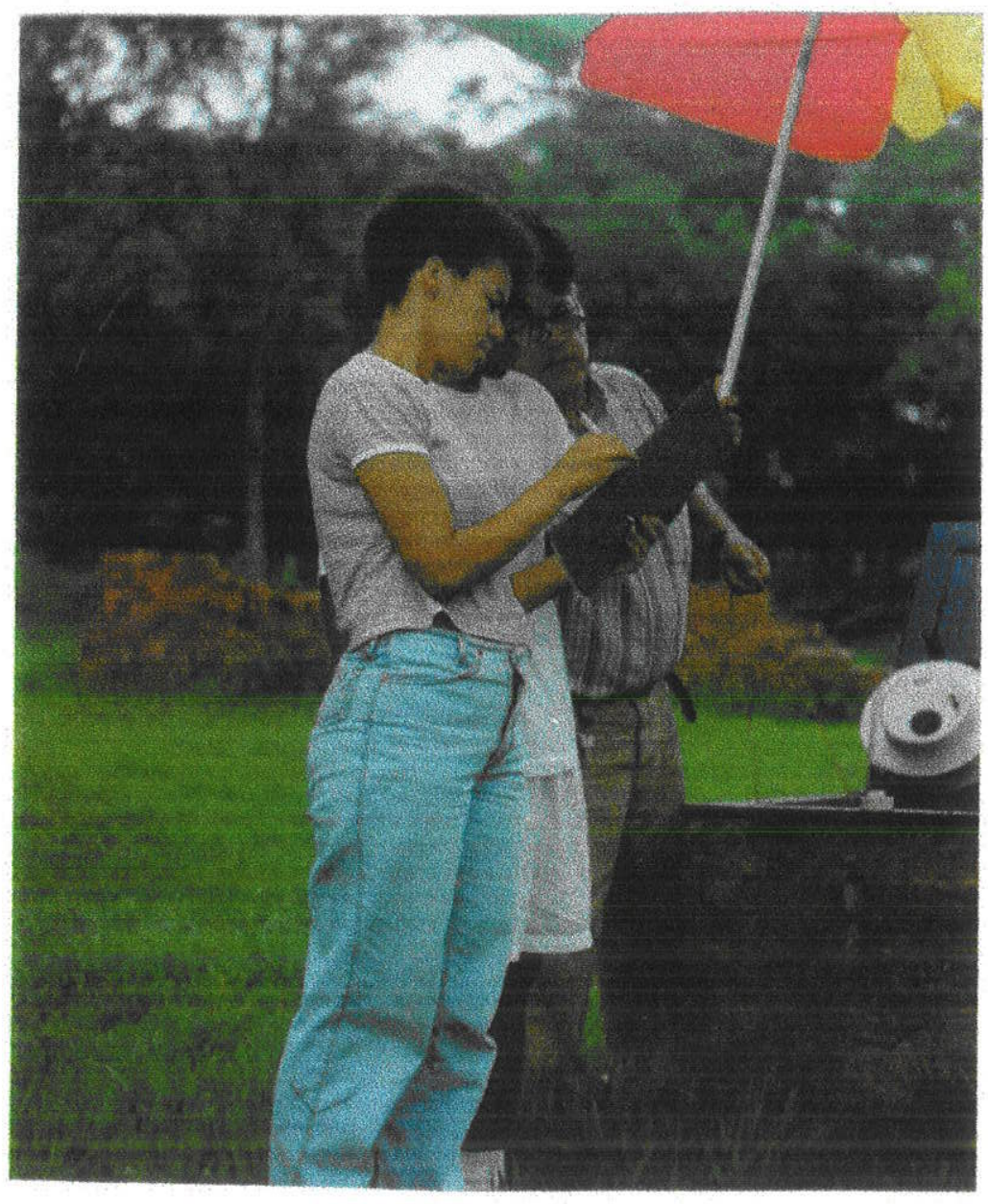

Foto 12: Medição do nivel freătico - PM05 


\subsubsection{Hidrogeoquímica}

O Quadro 6 relaciona os dados necessários e os procedimentos que são adotados nas investigações referentes a eles.

Quadro 6: Propriedades e recursos técnicos relacionados à hidrogeoquimica e utilizados na pesquisa

\begin{tabular}{|c|c|c|}
\hline $\begin{array}{c}\text { NATUREZA DOS } \\
\text { DADOS }\end{array}$ & TECNICAS & $\begin{array}{l}\text { EQUIPAMENTOS E } \\
\text { LABORATÓRIOS }\end{array}$ \\
\hline & $\begin{array}{c}\text { - Monitoramento com } \\
\text { coleta mensal de amostras das } \\
\text { zonas saturadas e insaturadas } \\
\text { e do aqüífero explotado atra- } \\
\text { vés de poço tubular, } \\
\text { - Coleta de água da chuva }\end{array}$ & $\begin{array}{l}\text { - Pocos de monitoramento } \\
\text { - Coletores de água } \\
\text { - Extratores de cápsulas poro- } \\
\text { sas }\end{array}$ \\
\hline $\begin{array}{c}\text { BACKGROUND } \\
\text { HIDROGEOQUÍMICO }\end{array}$ & $\begin{array}{c}\text { - Análises químicas da água } \\
\text { amostrada }\end{array}$ & $\begin{array}{l}\text { Laboratório de análises } \\
\text { químicas do CAS/IGUSP }\end{array}$ \\
\hline $\begin{array}{l}\text { LIXIVIAÇÃO E RETENÇÃO } \\
\text { DE CONTAMINANTES } \\
\text { (adsorção, complexação, etc.) }\end{array}$ & $\begin{array}{l}\text { - Análise química de solo e de } \\
\text { rocha da zona não saturada }\end{array}$ & $\begin{array}{l}\text { Laboratório de Sedimento- } \\
\text { logia da FCT/UNESP } \\
\text { Laboratório de Geoquímica } \\
\text { do Dartamento de Petrolo- } \\
\text { gia do IGCE/UNESP }\end{array}$ \\
\hline
\end{tabular}

Distinguem-se duas etapas no monitoramento: uma referente à hidroquimica durante um período em que não é introduzido o contaminante escolhido (estudo do "background") e outra referente ao seu comportamento após a sua introdução. 
No caso do presente estudo, a introdução do contaminante foi acidental, tendo acontecido já no andamento dos trabalhos de investigação.

Houve rompimento, a 24/04/97, de um coletor de água residuária, enterrado no solo a 0,46 m de profundidade e localizado a montante e a uma distância de $12 \mathrm{~m}$ aproximadamente da EP. Os reparos dos danos foram providenciados somente a 19/05/97, estendendo-se, portanto, o vazamento por 26 dias. Este coletor, pelo que se deduz de sua localização, reúne as águas servidas de 2 prédios discentes que, durante a semana letiva, podem ser freqüentados por 1.380 alunos em caso de comparecimento total. De acordo com os dados da diretoria de serviços do Campus, estima-se o lançamento médio por dia de esgoto, a partir destas instalações, em uma quantidade variável entre $6 \mathrm{~m}^{3}$ e $12 \mathrm{~m}^{3}$ no periodo letivo. Por esta informações, depreende-se que foram introduzidos no solo, sem escoamento superficial e com percolação imediata dentro dele, pelo menos $156 \mathrm{~m}^{3}$ ou 156.000 I de água residuária, portadora de $\mathrm{N}, \mathrm{F}, \mathrm{Cl}$, $\mathrm{P}$ e $\mathrm{F}$ em solução. Por estes valores admitidos com moderação, o efeito em volume de água desse vazamento, se comparado com parâmetros de precipitação em uma área de $10 \mathrm{~m} \times 20 \mathrm{~m}$, equivale a de uma chuva continuada de $780 \mathrm{l} / \mathrm{m}^{2}$ ou de $780 \mathrm{~mm}$, o que correspondende, na zona climática de Presidente Prudente, a mais da metade do valor médio de precipitação acumulada por ano, no período de 1969 a 1996.

Registrou-se outro acidente de vazamento no mesmo local a 23/03/98, tendo sido a sua duração de 20 dias. Adotando-se os termos de cálculo do vazamento anterior, o efeito de acréscimo de água é comparável ao de uma precipitação continuada de $600 \mathrm{~mm}$ numa área de $10 \mathrm{~m} \times 20 \mathrm{~m}$.

Outro acidente que ocorreu com instalações hidráulicas da FCT/UNESP foi um vazamento de conduto de água destinada ao abastecimento do Campus, a cerca de $14,30 \mathrm{~m}$ de uma cacimba, designada como " $\mathrm{C} 2$ " no programa de monitoramento Esta adutora, foi rompida às $10,30 \mathrm{~h}$ do dia $16 / 05 / 97$, tendo, água já cloretada e fluoretada jorrado continuamente e com vazão regular de pelo menos $10 \mathrm{~m}^{3} / \mathrm{h}$, para um rego de terra nua, por um intervalo de tempo de mais de 6 horas, alcançando o máximo de infiltração possivel no solo nas condições climáticas desse dia. 


\subsubsection{Coleta de amostras de água}

$\mathrm{Na}$ coleta mensal de água, foram empregados frascos e garrafas de polietileno, todos estes utensílios lavados previamente com detergente, ácido e água destilada.

Antes de se proceder à amostragem no campo, o material utilizado para as coletas de águas de chuva e dos poços também foi lavado com a água a ser amostrada. Este procedimento não foi adotado em relação à coleta através dos extratores de cápsulas porosas, devido ao volume de água obtido, o qual foi muito reduzido em todas as oportunidades de coleta.

A conservação das amostras após as coletas obedeceu a normas adotadas pela CETESB (1988), nas quais se recomenda a divisão da amostra, imediatamente após a coleta, em três partes, uma delas a ser mantida sob congelamento e as outras duas, com o pH baixado a 2 pela adição, respectivamente, de $\mathrm{H}_{2} \mathrm{SO}_{4}$ e $\mathrm{HNO}_{3}$ concentrados.

A - Coleta da zona não saturada

Para a extração da água da zona não saturada, é necessário que as cápsulas porosas sejam mantidas sob vácuo durante determinado periodo de tempo. Assim, o potencial no interior do tubo torna-se menor que o potencial do solo, o que provoca o deslocamento da água para uma cámara coletora do extrator. Lacrados, para não se desfazer o vácuo estabelecido no seu interior, os extratores assim permanecem por 24 horas, quando então se procede às coletas de água.

Para a retirada da água acumulada no interior das cápsulas, utilizou-se um frasco kitasato, submetido a vácuo, conectado às cápsulas através de mangueira pela qual a água pode subir. A coleta de água de cápsulas localizadas a mais de 6,0 $\mathrm{m}$ de profundidade exigiu a injeção de ar comprimido nos extratores. 


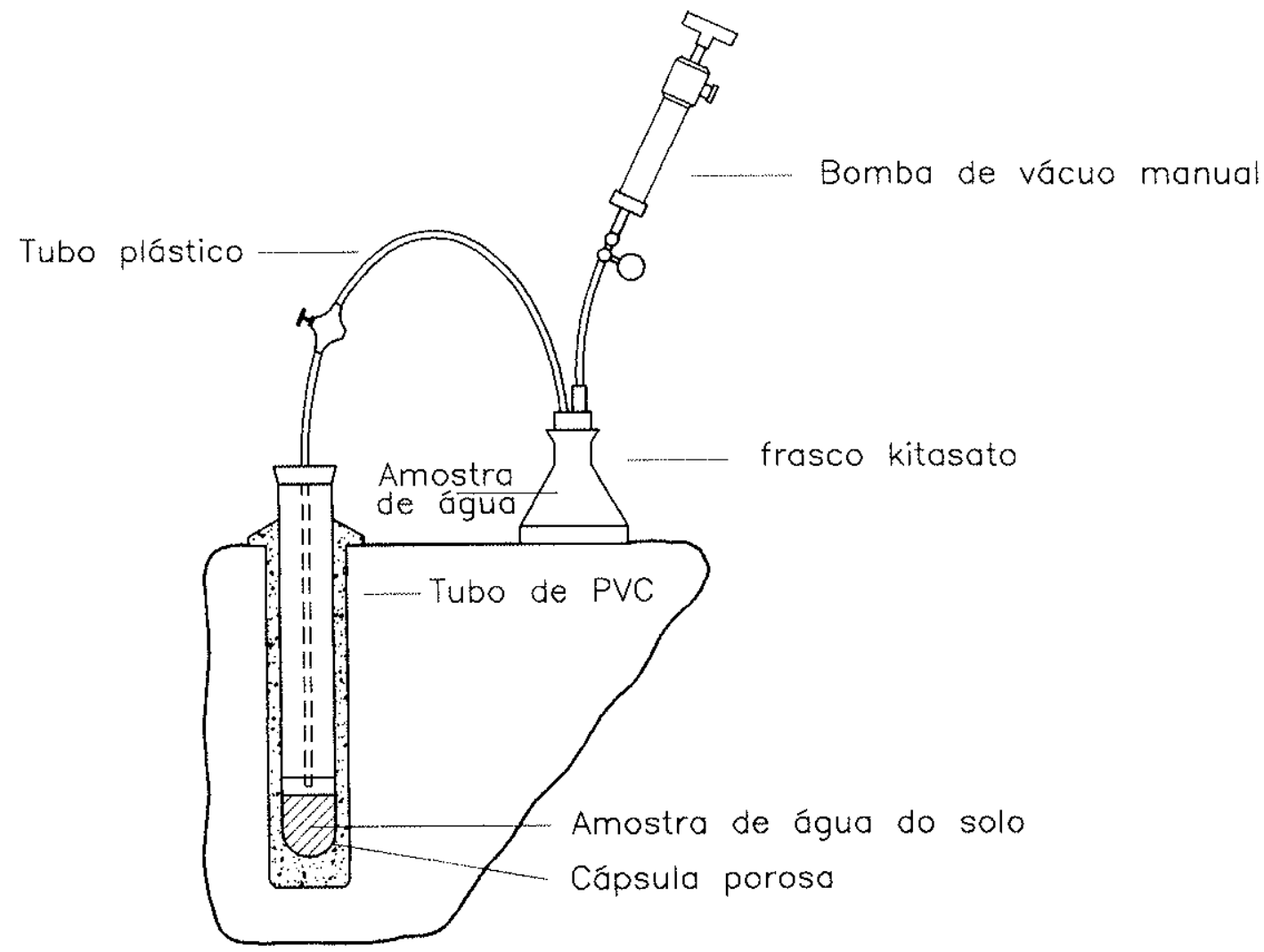

Figura 17 : Esquema do extrator de cápsula porosa 
Devido a dificuldades de coleta, alguns recursos foram introduzidos no procedimento de amostragem, a fim de se garantir a sua eficiência. Esses recursos foram:

1) uso de uma bomba marca Pfeiffer, com capacidade de $3 \mathrm{~m}^{3} / \mathrm{h}$ e produção de vácuo mecânico, que varia entre $10^{-1}$ a $10^{-3}$ torr ( 13,33 a 0,13 Pa);

2) adaptação à bomba de vácuo de conexôes e mangueiras próprias para as condições de alto vácuo;

3) experimentos com período de bombeamento de 1,2 e 3 horas na retirada do ar dos extratores;

4) testes, na operação de extração da água, de sucção da bomba com entrada controlada de ar para condensar a água pulverizada (operação de "ballast" );

5) testes com bomba manual;

6) testes de bombeamento com umedecimento prévio da cápsula;

7) verificação em cada extrator da manutenção da condição de vácuo, após a operação de retirada do ar;

8) experimentos com a operação conjunta de 2 bombas de vácuo para a retirada do ar.

9) proteção com "mulching" (cobertura de palha úmida) contra a evaporação, após a introdução da condição de vácuo.

B - Coleta do aqüifero livre

Quanto à coleta de água dos poços de monitoramento, inicialmente foi adotada a providência de esgotar repetidamente, durante dois meses, os poços de monitoramento. Esse cuidado prévio teve dois objetivos: a eliminação de influências de contaminaçăo da água utilizada na perfuraçăo, a qual foi relativamente abundante e de procedéncia estranha ao aqüífero em estudo; a reduçăo da turbidez, devida a operaçőes de instalação do poço, na água afluente a este.

A cacimba C2 foi incluída no programa de coleta de amostras. A cacimba C1 não foi utilizada para a amostragem, por problema de impurezas no seu interior. 

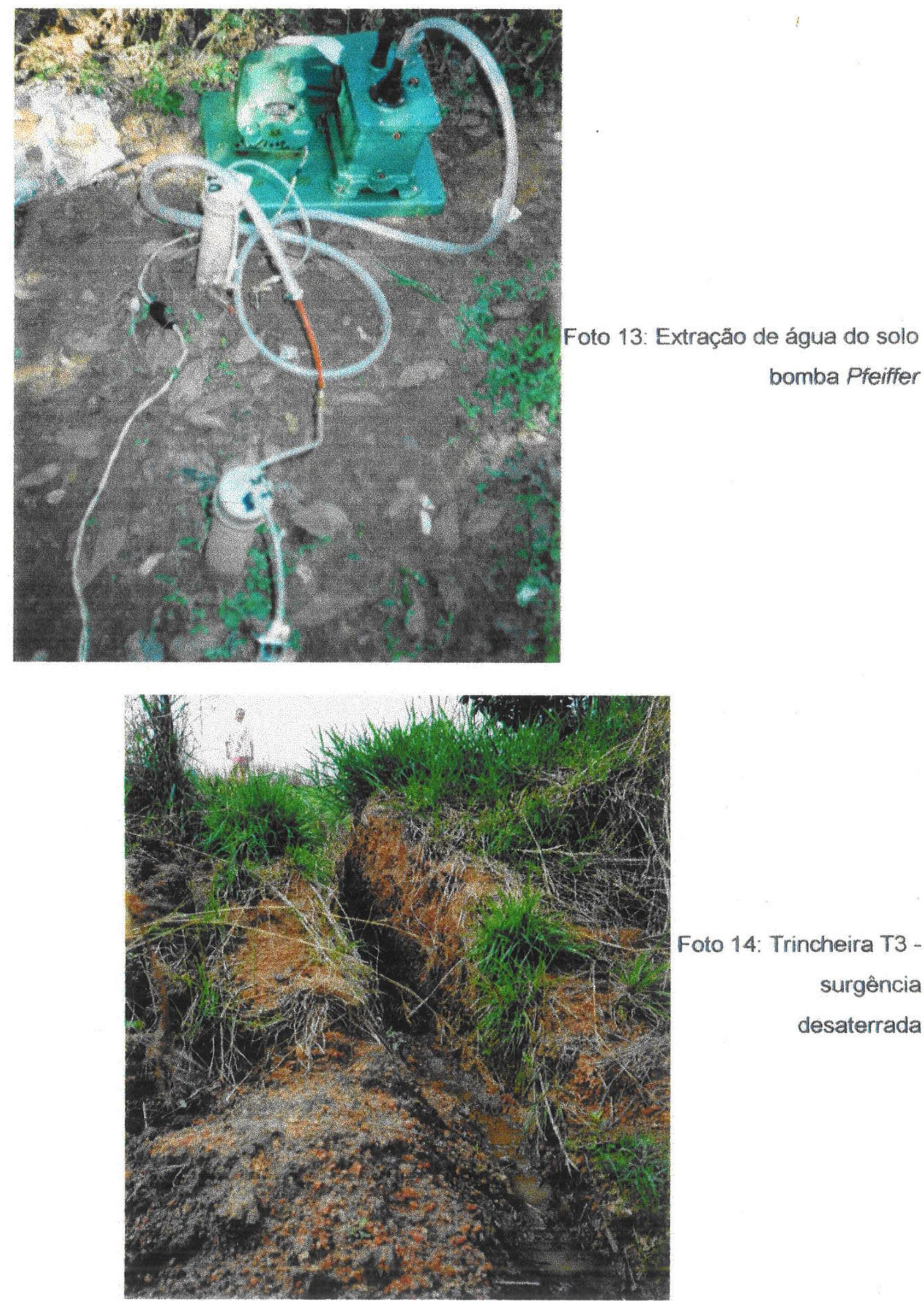
O procedimento de amostragem, de prefierencia efetuada mensalmente, incluiu o esgotamento dos poços, que foi antecipado à coleta em intervalo de tempo necessám rio à recuperação do nível estático da água.

Quanto à amostragem do poço tubular, as coletas foram efetuadas em oportunidades em que o poço estava em pleno funcionamento, seguindo também um programa de coleta mensal.

C- Coleta junto às surgências

Foi efetuada apenas a coleta junto a uma delas, uma vez que junto às demais a interferência de obras de construção do açude e obras de terraceamento impossibilitaram qualquer tipo de captação. Para se proceder à amostragem na surgência menos prejudicada por essas intervenções, foi necessário expô-la novamente através de escavação de uma trincheira de mais de $15 \mathrm{~m}$ de extensão.

D - Coleta de água de chuva

As amostras foram coletadas durante ou imediatamente após eventos de precipitação, de preferência em dois locais diferentes, um deles na EP e sujeito à interceptação pela copa de uma árvore e outro localizado a uma distância de 20 metros pelo menos de qualquer árvore ou qualquer outro obstáculo à chegada livre da água à superficie do terreno. Como coletores, foram empregados recipientes de alumínio, previamente lavados. 


\subsubsection{Análises químicas}

As determinações efetuadas imediatamente após a coleta consistiram em:

- $\mathrm{pH}$, com o peagâmetro Micronal B375, do Laboratório de Sedimentologia da FCT/UNESP.

- condutividade elétrica, com o condutivímetro Micronal B331, do Laboratório de Sedimentologia da FCT/UNESP.

- dosagens de $\mathrm{CO}_{3}{ }^{2-}$ e $\mathrm{HCO}_{3}{ }^{\circ}$, por titulometria, de acordo com o procedimento recomendado pela A.P.H.A. (1982), com emprego de solução $0,002 \mathrm{~N}$ de $\mathrm{HCl}$, fenolftaleina e alaranjado de metila.

Análises referentes aos ânions $\mathrm{F}^{\circ}, \mathrm{Cl}^{-}, \mathrm{NO}_{2}^{-}, \mathrm{Br}^{-}, \mathrm{NO}_{3}^{-}, \mathrm{PO}_{4}{ }^{3-}$ e $\mathrm{SO}_{4}^{-2}$ foram realizadas através de processo de cromatografia líquida, no aparelho DIONEX $2010 i$. Para a determinação dos cátions $\mathrm{Na}^{+}$e $\mathrm{K}^{+}$, foi empregado o processo de fotometria de chama desenvolvido no fotômetro $B 262$ da Micronal e para os cátions $\mathrm{Cu}^{2+}, \mathrm{Pb}^{2+}$, $\mathrm{Zn}^{2+}, \mathrm{Fe}^{3+}$, Cromo total, $\mathrm{Mn}^{2+}, \mathrm{Ni}^{2+}, \mathrm{Ba}^{2+}, \mathrm{Al}^{3+}, \mathrm{Sr}^{2+}$. Para os cátions $\mathrm{Ca}^{2+}$ e $\mathrm{Mg}^{2+}$ utilizouse o método de espectrofotometria, com o equipamento para análise de absorção atômica CG AA7000 BC. Todas as análises destes ions foram efetuadas no Laboratório de Hidroquímica do Centro de Pesquisas de Águas Subterrâneas - CAS/IGUSP.

Nos laboratórios de análises químicas da Companhia de Saneamento Básico do Estado de São Paulo - SABESP e da CETESB - Companhia de Tecnologia e Saneamento Básico, foram determinados os teores de $\mathrm{N}$ amoniacal e $\mathrm{N}$ total de 1 amostra colhida no tubulação de esgoto rompido e 2 amostras do açude.

Análises destinadas à verificação do teor de metais retidos no meio poroso da zona não saturada foram efetuadas em amostras do solo e do substrato rochoso. Para esta finalidade, foram selecionadas as amostras referentes a: 
- horizontes identificados no solo removido para a instalação de lisimetros de sucção em área próxima da estufa e anteriormente ocupada por um parreiral;

- material retirado para a instalação do poço de monitoramento PM01;

- material removido para a instalação do poço de monitoramento localizado poucos metros a jusante da fossa de lixa do laboratório (PM05);

- estratos que, pelo cimento da rocha ou pelo conteúdo de argila, representam barreira potencial ao transporte de contaminantes.

A exemplo do procedimento adotado para amostras destinadas a análises granulométricas, a trituração e a quarteação foram incluídas no preparo das amostras.

As análises foram realizadas pelo Laboratório de Geoquímica do Instituto de Geociências e Ciências Exatas - UNESP, Rio Claro/SP. O procedimento de análise inciuiu a separaçăo de $100 \mathrm{~g}$ do material de cada amostra, a secagem a $110^{\circ} \mathrm{C}$, o preparo do extrato aquoso através do banho e repouso do material durante $24 \mathrm{~h}$ com água deionizada. As determinações foram realizadas pelo método de ICP-AES. 


\section{RESULTADOS E DISCUSSÃO}

\subsection{DADOS CLIMATOLÓGICOS}

Além da utilização de dados de precipitação diária como variáveis importantes na análise da hidrodinâmica das zonas não saturada e saturada, as informações coIhidas junto à estação meteorológica foram empregadas nos cálculos de balanço hídrico referentes ao período que se estendeu de junho de 1996 a junho de 1998 (Tabela 2, Figura 18).

Tabela 2: Balanço hidrico seriado - Presidente Prudente-SP - julho/96 a julho/98

\begin{tabular}{|c|c|c|c|c|c|c|c|c|c|c|}
\hline MES & $\mathbf{P}$ & ETP & P.ETP & NAC & ARM & ALT & ETR & DEF & EXC & \\
\hline JUL 96 & 2,8 & 52,8 & $-50,0$ & $-95,7$ & 38,4 & $-24,9$ & 27,7 & 25,1 & 0,0 & 27,7 \\
\hline AGO 96 & 26,0 & 87,5 & $-61,5$ & $-157,2$ & 20,8 & $-17,6$ & 43,6 & 43,9 & 0,0 & 43,6 \\
\hline SET 96 & 87,4 & 85,6 & 1,8 & $-149,1$ & 22,5 & 1,8 & 85,6 & 0.0 & 0,0 & 87.4 \\
\hline OUT 96 & 163,0 & 120,0 & 43,0 & $-42,3$ & 65,5 & 43,0 & 120,0 & 0,0 & 0,0 & 163,0 \\
\hline NOV 96 & 189.8 & 127,3 & 62,5 & 0.0 & 100,0 & 34,5 & 127,3 & 0.0 & 28.0 & 161,8 \\
\hline DEZ 96 & 260,4 & 141,9 & 118,5 & 0,0 & 100,0 & 0,0 & 141,9 & 0,0 & (18,5 & 141,9 \\
\hline 1997 JAN 97 & 201,7 & 132,0 & 69,7 & 0,0 & 100,0 & 0,0 & 132,0 & 0,0 & 697 & 132,0 \\
\hline FEV 97 & 241,1 & 124,0 & 117,1 & 0,0 & 100,0 & 0,0 & 124,0 & 0,0 & 117,1 & 124,0 \\
\hline MAR 97 & 184,6 & 124,5 & 60,1 & 0,0 & 100,0 & 0.0 & 124,5 & 0,0 & $60 ; 1$ & 124,5 \\
\hline ABR 97 & 101,2 & 89.1 & 12.1 & 0,0 & 100,0 & 0.0 & 89,1 & 0.0 & 12,1 & 89.1 \\
\hline MAI 97 & 67,6 & 66,8 & 0,8 & 0,0 & 100,0 & 0,0 & 66,8 & 0,0 & 0,8 & 66,8 \\
\hline JUN 97 & 3,8 & 42,6 & $-38,8$ & $-38,8$ & 67,8 & $-32,2$ & 36,0 & 6,7 & 0,0 & 36,0 \\
\hline 1997 JUL 97 & 2,8 & 67,3 & $-64,5$ & $-103,4$ & 35,6 & $-32,2$ & 35,0 & 32,3 & 0,0 & 35,0 \\
\hline AGO 97 & 26,0 & 80,9 & $.54,9$ & $-158,3$ & 20,5 & $-15,0$ & 41,0 & 39,9 & 0,0 & 41,0 \\
\hline SET 97 & 87,4 & 114,8 & $-27,4$ & $-185,7$ & 15,6 & $-4,9$ & 92,3 & 22,5 & 0,0 & 92,3 \\
\hline OUT 97 & 163,0 & 123,0 & 40,0 & $-58,6$ & 55,7 & 40,0 & 123,0 & 0,0 & 0,0 & 163,0 \\
\hline NOV 97 & 189,8 & 133,9 & 55,9 & 0,0 & 100,0 & 44,3 & 133,9 & 0,0 & 11,5 & 178,3 \\
\hline DEZ 97 & 260,4 & 161,8 & 98,6 & 0,0 & 100,0 & 0,0 & 161,8 & 0,0 & 98,6 & 161,8 \\
\hline 1998 JAN 98 & 156,8 & 177,8 & $-21,0$ & $-21,0$ & 81,1 & $-18,9$ & 175,7 & 2,0 & 0,0 & 175,7 \\
\hline FEV 98 & 88,9 & 130,5 & $-41,6$ & $.62,6$ & 53,5 & $-27,6$ & 116,5 & 14,0 & 0,0 & 116,5 \\
\hline MAR 98 & 340,0 & 133,2 & 206,8 & 0,0 & 100,0 & 46,5 & 133,2 & 0,0 & $160 ; 3$ & 179,7 \\
\hline ABR 98 & 155,4 & 92,5 & 62,9 & 0,0 & 100,0 & 0,0 & 92,5 & 0,0 & 629 & 92,5 \\
\hline MAI 98 & 86,2 & 59,0 & 27,2 & 0,0 & 100,0 & 0,0 & 59,0 & 0,0 & 27,2 & 59,0 \\
\hline JUN 98 & 6,4 & 50,1 & $-43,7$ & $-43,7$ & 64,6 & $-35,4$ & 41,8 & 8,3 & 0,0 & 41,8 \\
\hline JUL 98 & 7,2 & 67,5 & $-60,3$ & $-104,1$ & 35,3 & $-29,3$ & 36,5 & 31,1 & 0,0 & 36,5 \\
\hline
\end{tabular}

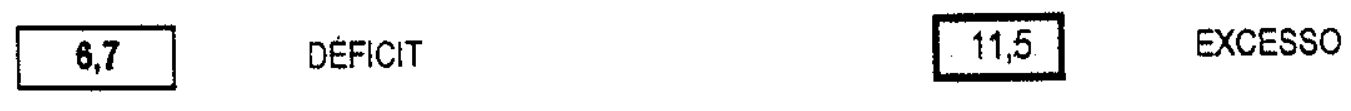




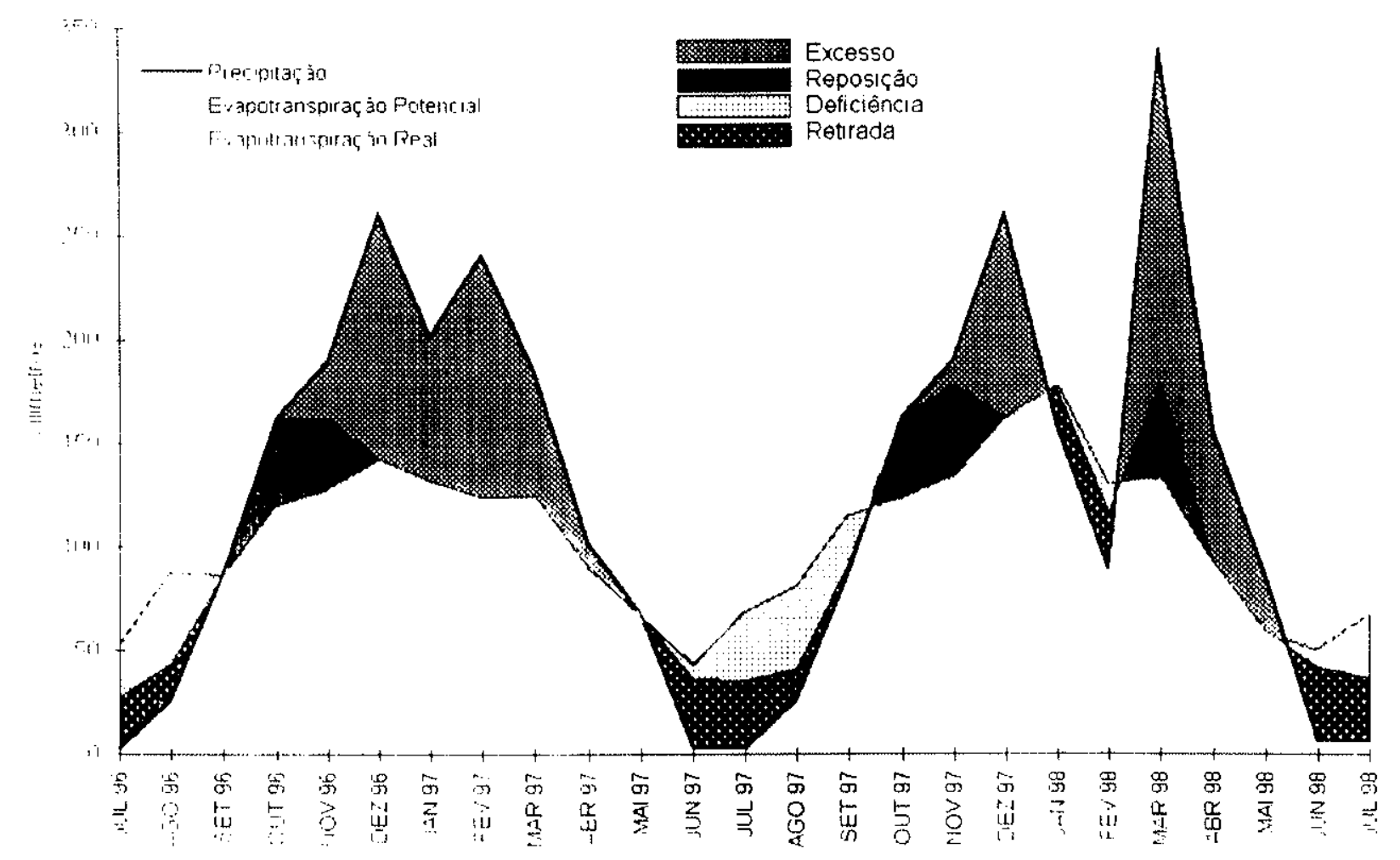

Figura 18: Balanço hidrico - Método de Thorntwaite $-07 / 96$ a $07 / 98$

De acordo com este gráfico, a distribuição sazonal de excesso, reposição, deficiência e retirada de água do solo, no período considerado, apresenta comportamento semethante àquele traduzido no gráfico referente ao periodo de 1969-1995, elaborado na Estação Meteorológica da UNESP de Presidente Prudente. A discordância entre os dois consiste na maior quantidade excedente nos anos de 1996, 1997 e 1998 e na localização do pico de excesso no ano de 1998, que ocorre em março e abril, em discordância com a maior elevação observada em média, que se dá em janeiro e dezembro. 


\subsection{RESULTADOS REFERENTES À LITOLOGIA E À PEDOLOGIA}

Ao longo do córrego cuja bacia drena o setor SW do Campus e do Córrego do Veado, onde é inferida uma zona de falha, são identificados alinhamentos tectôni$\cos$ (GODOY, 1989). A sua localização pode contribuir para a explicação do aparecimento freqüente de surgências de água no setor inferior de vertentes associadas a este córrego.

$\mathrm{Na}$ área pesquisada, o mapeamento geológico de detalhe localizou uma feição característica da Região de Presidente, que é o afloramento de camadas mais compactas de arenito, siltito ou lamito indiferenciado (Figura 11).

Observa-se também uma feição comum na região, configurada no aparecimento difuso do freático, onde a água poreja em escarpa de rocha alterada. Esta feição de surgência discreta mas relativamente extensa é mapeada como zona de ressudação por SUDO (1980).

Quanto ao escoamento subterrâneo em direção aos fundos de vale, na área de estudo ele é condicionado às orientações dos declives do terreno, com uma disposição preferencial em três faces de vertente: duas voltadas ao córrego do Veado a $\mathrm{N}$ e a NE e uma, a SW, voltada a um afluente deste córrego (GODOY,1997).

A fim de ser analisada e avaliada a influência das diferenciações em perfil do regolito e do substrato rochoso, foram reunidos os resultados da descrição de amostras de solo e rocha amostrados nos poços de monitoramento (Quadro 7) e 3, os dados obtidos com referência às propriedades de distribuição granulométrica, porcentagem de cimento carbonático e compacidade (Tabela 3 ).

Para a análise granulométrica, optou-se pela classificação adotada para solos, dada a dificuldade prática de introduzir o fracionamento do silte na rotina do Laboratório. Na tabela não estão incluídos os resultados referentes ao fracionamento da areia, que apontam a predomináncia bem distinta de areia muito fina e fina.

As descrições das características do material amostrado, embora não disponham de dados quantitativos, foram suficientes para se descartar a possibilidade de estabelecer correlações litológicas em perfil. Isto significa que não foi encontrada, na área da pesquisa, a continuidade lateral, aparentemente existente em alguns afloramentos localizados nas redondezas da área, conforme é ilustrado nas Fotos 1 e 2 . 
Quadro 7 : Descrição das amostras dos poços de monitoramento

\begin{tabular}{|c|c|c|}
\hline PROF. (m) & NIVEL(m) & DESCRIÇĀO \\
\hline \multicolumn{3}{|c|}{ POÇO: PM02 } \\
\hline $0-4,90$ & 438,62 & Solo \\
\hline $4,90-6,50$ & 433,72 & Lamito pardo \\
\hline $6,50-7,40$ & 432,12 & Arenito rosado, argiloso, friável \\
\hline $7,40-9,00$ & 431,22 & Arenito rosado bem claro, friável \\
\hline $9,00-10,00$ & 429,62 & Arenito rosado variando para argiloso novamente \\
\hline $10,00 * 11,00$ & 428,62 & Lamito compacto, cor chocolate, lâminas brancas \\
\hline $11,00-13,00$ & 427,62 & Arenito fino a médio, alaranjado, friável, poroso \\
\hline \multicolumn{2}{|l|}{ POÇO: } & \\
\hline $0-4,20$ & 436,55 & Solo \\
\hline $4,20-5,90$ & 432,35 & Arenito argiloso avermelhado, nódulos ferruginosos \\
\hline $5,90-6,10$ & 430,65 & Arenito rosado, friável, poroso \\
\hline $6,10-6,40$ & 430,45 & $\begin{array}{l}\text { Arenito fino, vermelho, friável, poroso, passando a mais compacto e } \\
\text { nitidamente laminado }\end{array}$ \\
\hline $6,40-8,60$ & 430,15 & Arenito rosado, friável, passando a argiloso e compacto \\
\hline $8,60-9,40$ & 427,95 & Arenito argiloso, pardo avermelhado \\
\hline $9,40-12,00$ & 427,15 & Arenito rosado, fino a médio, friável, com estratos mais argilosos \\
\hline $12,00-12,60$ & 424,65 & Lamito chocolate \\
\hline \multicolumn{2}{|l|}{ POÇO: } & \\
\hline $0-2,30$ & 435,80 & Solo \\
\hline $1,90-4,50$ & 433,50 & Arenito rosado, friável \\
\hline $4,50-5,50$ & 431,30 & Arenito vermelho, friável \\
\hline $5,50-6,60$ & 430,30 & Arenito rosado claro, friável, passando a mais compacto \\
\hline $6,60-8,80$ & 429,20 & Arenito rosado claro, friável \\
\hline $8,80-10,00$ & 427,00 & Arenito médio, muito poroso \\
\hline $10,00-10,90$ & 425,80 & Arenito médio, argiloso \\
\hline $10,90-11,40$ & 424,90 & Lamito marrom avermelhado, com impregnação de carbonato \\
\hline POÇ: & PM05 & \\
\hline $0-1,90$ & 428,40 & Solo \\
\hline $1,90-2,10$ & 426,50 & Solo com nódulos ferruginosos \\
\hline $2,10-3,50$ & 426,30 & Arenito avermelhado, friável \\
\hline $3,50-4,10$ & 424,90 & Lamito variegado \\
\hline $4,10-5,60$ & 424,30 & Arenito chocolate, friável \\
\hline $5,60-6,40$ & 422,80 & Arenito variegado, relativamente mais compacto \\
\hline \multicolumn{2}{|c|}{ POÇ: PM06 } & \\
\hline $0-0,40$ & 418,24 & Solo \\
\hline $0,40-0,90$ & 417,84 & Arenito muito alterado, amarelo a variegado, muito friável \\
\hline $0,90-6,50$ & 417,34 & Arenito alaranjado, muito friável \\
\hline $6,50-7,50$ & 411,74 & Arenito vermelho claro, friável, muito úmido \\
\hline \multicolumn{2}{|c|}{ POÇO: PMO7 } & \\
\hline $0-0,20$ & 412,21 & Solo \\
\hline $0,20-0,40$ & 412,01 & Lamito chocolate \\
\hline $0,40-0,50$ & 411,81 & Arenito creme \\
\hline $0,50-0,90$ & 411,71 & Arenito vermelho claro, mais compacto \\
\hline $0,90-4,00$ & 411,31 & Arenito vermelho claro, friável \\
\hline $4,00-4,70$ & 408,21 & Arenito vermelho claro, compacto \\
\hline $4,70-6,00$ & 407,51 & Arenito vermelho claro, friável \\
\hline $6,00-6,70$ & 406,21 & Arenito vermelho, compacto \\
\hline $6,70-8,00$ & 405,51 & Arenito vermelho, friável \\
\hline
\end{tabular}


Tabela 3 : Resultados de análise granulométrica e grau de cimentação - amostras de solo e rocha

\begin{tabular}{|c|c|c|c|c|c|c|c|c|}
\hline LOCAL & $\begin{array}{l}\text { PROF. } \\
(m)\end{array}$ & $\begin{array}{c}\text { AREIA } \\
\%\end{array}$ & $\begin{array}{c}\text { SILTE } \\
\%\end{array}$ & $\begin{array}{c}\text { ARGILA } \\
\%\end{array}$ & $\begin{array}{c}\text { CIME } \\
\text { c/ } \mathrm{HCl}\end{array}$ & $\begin{array}{c}\text { NTO (\%) } \\
\text { calcina- } \\
\text { do }\end{array}$ & $\begin{array}{l}\text { CLASSI- } \\
\text { FICAÇÃO }\end{array}$ & $\begin{array}{c}\text { CONDI- } \\
\text { ÇAO DE } \\
\text { BARREIRA }\end{array}$ \\
\hline \multirow{6}{*}{$\begin{array}{l}\text { PAR- } \\
\text { REI- } \\
\text { RAL }\end{array}$} & $0,20-0,50$ & 64,65 & 14,35 & 21,00 & ND & ND & SOLO & \\
\hline & $0,50-0,90$ & 62,66 & 16,04 & 21,30 & ND & ND & SOLO & Hor. $\mathrm{B}$ \\
\hline & $0,90-1,10$ & 63,56 & 11,94 & 24,50 & ND & ND & SOLO & Hor.Bt \\
\hline & $1,10-1,50$ & 64,44 & 14,36 & 21,20 & ND & ND & SOLO & Hor. Bt \\
\hline & $1,50-2,00$ & 63,14 & 15,66 & 21,20 & ND & ND & SOLO & Hor.BC \\
\hline & $2,00-2,50$ & 53,92 & 28,28 & 17,80 & ND & ND & SOLO & Hor.C \\
\hline \multirow{6}{*}{ PM02 } & $3,00-4,00$ & 58,50 & 19,90 & 21,60 & ND & ND & ARENITO & Compacto \\
\hline & $5-6,00$ & 56,12 & 23,68 & 20,60 & ND & ND & & \\
\hline & $8,00-9,00$ & 78,42 & 14,08 & 7,50 & ND & $\mathrm{ND}$ & ARENITO & \\
\hline & $10-11,00$ & 38,61 & 36,49 & 24,90 & ND & ND & LAMITO & Compacto \\
\hline & $11-12, \infty$ & 77,47 & 14,93 & 7,60 & ND & ND & ARENITO & \\
\hline & $12-13, \infty 0$ & 92,32 & 6,48 & 1,20 & ND & ND & ARENITO & \\
\hline \multirow{6}{*}{ PM03 } & 4,00 & 60,83 & 16,97 & 22,20 & ND & ND & ARENITO & \\
\hline & $6,30-6,70$ & 63,06 & 31,24 & 5,70 & ND & ND & ARENITO & Compacto \\
\hline & 7,00 & 77,84 & 16,56 & 5,60 & ND & ND & ARENITO & \\
\hline & 8,00 & 70,14 & 19,86 & 10,00 & ND & ND & ARENITO & \\
\hline & 9,00 & 60,08 & 31,22 & 8,70 & ND & ND & & \\
\hline & $12-12,60$ & 68,53 & 22,87 & 8,60 & ND & ND & ARENITO & \\
\hline \multirow[t]{2}{*}{ PM04 } & $6,00-6,50$ & 56,62 & 32,98 & 10,40 & 10,56 & 7,93 & LAMITO & Compacto \\
\hline & $11-11,40$ & 50,70 & 33,12 & 16,18 & ND & ND & LAMITO & \\
\hline \multirow{6}{*}{ PM05 } & $0,0,20$ & 64,72 & 10,28 & 25,00 & ND & ND & ARENITO & \\
\hline & $0,20-0,50$ & 59,43 & 14,57 & 26,00 & ND & ND & LAMITO & \\
\hline & 2,00 & 62,66 & 18,54 & 18,80 & ND & ND & & \\
\hline & 3,00 & 71,26 & 12,04 & 16,70 & ND & ND & ARENITO & Compacto \\
\hline & $4,00-4,20$ & 48,89 & 34,21 & 16,90 & ND & ND & LAMITO & \\
\hline & $5,60-6,40$ & 43,83 & 43,87 & 12,30 & ND & ND & LAMITO & Compacto \\
\hline $\begin{array}{c}\text { SURGÉN- } \\
\text { CIA } \\
\end{array}$ & BASE & 44,93 & 42,17 & 12,90 & ND & ND & LAMITO & Compacto \\
\hline \multirow{3}{*}{$\begin{array}{c}\text { POÇO } \\
\text { TUBU- } \\
\text { LAR }\end{array}$} & 16,00 & & & & 5,55 & 2,58 & ARENITO & Compacto \\
\hline & 20,00 & 57,97 & 27,50 & 14,53 & 5,20 & 3,18 & LAMITO & Compacto \\
\hline & 21,00 & 28,04 & 42,02 & 21,94 & 18,12 & 8,27 & LAMITO & Compacto \\
\hline
\end{tabular}


Quadro 8: Características morfológicas do solo encontrado na trincheira T1

Ap - 0-35cm; desuniforme, vermelho escuro acinzentado (10R 3/2, úmido); areia franca; estrutura maciça, que se desfaz em grãos simples e às vezes blocos pequenos a médios; consistência (úmida) friável; ligeiramente plástico e ligeiramente pegajoso; muito poroso; locas biológicas abundantes/ raizes fasciculadas abundantes, carvão em camada continua de 10 a 25 ; transição (limite) clara, amplamente ondulado.

AB - 35 a $55 \mathrm{~cm}$; vermelho (2,5 YR 4/6, úmido); areia franca; maciça, que se desfaz em fraca média blocos subangulares e granular; muito friável, ligeiramente plástico, não pegajoso; poros muito pequenos, porosidade baixa; raizes fasciculadas médias abundantes; transição abrupta e plana.

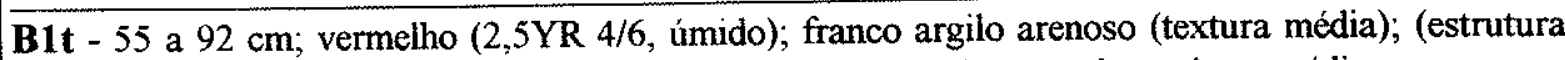
prismática), fraca pequena e média, que se rompe em blocos subangulares médios e pequenos e fracos; cerosidade abundante e muito fraca; macroporosidade muito abundante e locas de raizes carbonizadas muito abundantes; friável (úmida), muito plástico e muito pegajoso; raízes fasciculadas médias a grossas abundantes; transição difusa e plana.

B2t - 92 a $110 \mathrm{~cm}$; bruno avermelhado escuro (10YR 4/4, úmido); franco argilo arenoso (textura média); moderada média; blocos subangulares (prismática, que se desfaz em blocos médios irregulares, cerosidade abundante e fraca (filmes de argila abundantes mas muito fracos); friável (úmida), muito plástico e muito pegajoso; raizes fasciculadas médias a grossas abundantes; transição difusa e plana.

BC - 110 a $135 \mathrm{~cm}$; vermelho fraco (10R 4/4, úmido); franco argilo arenoso (média); maciça, que se desfaz em fraca pequena e média blocos subangulares; cerosidade ausente; macroporosidade comum, locas de raizes preenchidas com material iluvial; (úmido) firme, muito plástico, pegajoso; difusa e plana.

C - $135 \mathrm{~cm}$ para mais; vermelho (10R 4/6, úmido); franco arenoso; maciça, que se desfaz em fraca pequena e média blocos subangulares; macroporosidade visível; friável; plástico, pegajoso.

Observações: carvão esparso no perfil até a profundidade de $140 \mathrm{~cm}$; raizes fasciculadas médias a grossas até a profundidade de $130 \mathrm{~cm}$. 
Quadro 9 : Características morfológicas do solo encontrado na trincheira T3

A - 0-23cm; vermelho escuro acinzentado (2,5YR 4/8, úmido), manchas raras; arenoso; maciço, friável ; não plástico e não pegajoso; raizes fasciculadas finas e abundantes; transição clara, amplamente ondulado.

RA - $? 3$ a $45 \mathrm{~cm}$; vermelho (5 YR 4/3, úmido); 5 YR 5/8, com manchas comuns pequenas e sic: reia franca; prismática, em prismas pequenos; friável, ligeiramente plástico $\mathrm{e}$ 1. usigusus.

Bt - 45 a $60 \mathrm{~cm}$; vermelho amarelo (5YR 5/8, úmido) com manchas muito comuns cor de ferrugem ao longo de cavidades de raizes; argila barrenta; prismática, pequena e forte; plástico e pegajoso; nódulos lateríticos.

BCf - 60 a $85 \mathrm{~cm}$; vermelho amarelo (5YR 5/8, úmido), marchetado, com manchas abundantes; argila; nódulos lateriticos em mais de $70 \%$ da massa; muito plástico e muito pegajoso; raizes fasciculadas médias a grossas abundantes; transição difusa e plana.

$\mathrm{Cg}-85$ a $90 \mathrm{~cm}$

Observações:- em BA há a presença de argilominerais variados, com indicações de proporção elevada de argila complexa $(2: 1)$, verificando-se também o fenômeno da tixotropia;

BCf, localizado entre 60 e $85 \mathrm{~cm}$ de profundidade, significa B plíntico, isto é, apresentando plintita;

$\mathrm{Cg}$, entre 85 e $90 \mathrm{~cm}$, é hidromorfizado, apresentando muita umidade; no limite entre o horizonte $\mathrm{C}$ e a rocha semi-alterada, observa-se o fenômeno de escoamento subsuperficial (Foto ) 
Os resultados específicos à caracterização pedológica estão apresentados nas Tabelas 4, 5 e 6, em forma de dados de massa específica, variação granulométrica, $\mathrm{pH}$, capacidade de troca catiônica $(T)$, teor de bases trocáveis, teor de matéria orgânica e índices $\mathrm{K}_{\mathrm{r}}$ e $\mathrm{K}_{\mathrm{i}}$.

Das descrições morfológicas de 4 perfis de solo, correspondentes a 4 trincheiras, aqui são apresentadas aquelas relativas às trincheiras T1 (Quadro 8) e T3 .

Tabela 4: Análise granulométrica e índices fisicos do solo encontrado na trincheira $\mathrm{T} 1$

\begin{tabular}{|c|c|c|c|c|c|c|c|c|c|c|}
\hline $\begin{array}{c}\text { Amos- } \\
\text { tra }\end{array}$ & $\begin{array}{c}\mathbf{A}_{\mathbf{G}} \\
\mathbf{1 , 0 - 0 , 5} \mathrm{mm}\end{array}$ & $\begin{array}{c}\mathbf{A}_{\mathbf{M}} \\
0,5-0,25 \\
\mathrm{~mm}\end{array}$ & $\begin{array}{c}\mathbf{A}_{\mathbf{F}} \\
0,25-0,10 \\
\mathrm{~mm}\end{array}$ & $\begin{array}{c}\mathbf{A}_{\mathrm{MF}} \\
0,0-0,05 \\
\mathrm{~mm}\end{array}$ & $\begin{array}{c}\text { Areia } \\
\text { Total }\end{array}$ & $\begin{array}{c}\text { Silte } \\
0,05- \\
0,002 \mathrm{~mm}\end{array}$ & $\begin{array}{c}\text { Argi- } \\
\text { la< } \\
\mathbf{0 , 0 0 2} \mathbf{m m}\end{array}$ & $\boldsymbol{\rho}_{\mathbf{s}}$ & $\boldsymbol{\rho}$ & $\boldsymbol{\alpha}$ \\
\hline Ap & 0,10 & 1,00 & 19,80 & 54,90 & 80,20 & $\mathbf{8 , 8 0}$ & 10,90 & 2,63 & 1,46 & 44,48 \\
\hline AB & - & 1,90 & 14,70 & 63,30 & 79,90 & 10,30 & 9,80 & 2,62 & 1,45 & 44,65 \\
\hline B1t & - & 1,10 & 13,80 & 51,00 & 65,90 & 9,40 & 24,70 & 2,58 & 1,56 & 39,53 \\
\hline B2t & - & 1,00 & 11,40 & 50,60 & 63,00 & $\mathbf{8 , 8 0}$ & 28,20 & 2,53 & 1,58 & 37,54 \\
\hline BC & - & 0,60 & 13,00 & 50,40 & 64,00 & 10,75 & 25,25 & 2,62 & 1,45 & 44,65 \\
\hline C & - & 0,70 & 12,00 & 53,00 & 65,70 & 10,05 & 24,25 & 2,64 & 1,39 & 47,34 \\
\hline
\end{tabular}

$\rho=$ massa específica do solo coletado em amostra indeformada, contendo umidade

$\rho_{s}=$ massa específica das partículas que formam a fase sólida ou do solo seco

$\alpha=$ porosidade $=$ volume total de vazios em proporçăo ao volume do solo

Classificação pela textura:

$A p$ e $A B=$ Franco arenoso

Restante $=$ franco argilo arenoso 
Tabela 5 : Análise química do solo encontrado na trincheira T1

\begin{tabular}{|c|c|c|c|c|c|c|c|c|c|c|}
\hline Amostra & $\begin{array}{c}\text { pH } \\
\left(\mathrm{CaCl}_{2}\right)\end{array}$ & $\begin{array}{c}\text { M.O. } \\
\%\end{array}$ & $\begin{array}{c}\mathbf{P} \\
\left(\mathrm{Ug} / \mathrm{cm}^{3}\right)\end{array}$ & $\mathbf{K}$ & $\begin{array}{c}\mathrm{Ca} \\
\mathrm{meq}\end{array}$ & $\begin{array}{c}\mathrm{Mg} \\
/\end{array}$ & $\begin{array}{c}\mathrm{H}+\mathrm{Al} \\
\mathrm{cm}^{3}\end{array}$ & $\mathbf{S B}$ & $\mathrm{T}$ & $\mathbf{V}$ \\
\hline Ap & 4,9 & 1,0 & 3 & 0,20 & 1,5 & 0,4 & 1,8 & 2,1 & 3,7 & 54 \\
\hline A1 & 4,8 & 1,2 & 3 & 0,29 & 1,7 & 0,3 & 1,8 & 2,3 & 4,1 & 56 \\
\hline A3 & 4,7 & 0,9 & 2 & 0,22 & 1,2 & 0,2 & 1,5 & 1,6 & 3,1 & 52 \\
\hline B1 & 4,7 & 1,0 & 1 & 0,25 & 6,5 & 0,7 & 2,0 & 7,5 & 9,5 & 79 \\
\hline B2 & 5,0 & 1,1 & 1 & 0,18 & 7,0 & 0,6 & 1,8 & 7,8 & 9,6 & 81 \\
\hline B3 & 4,9 & 1,1 & 2 & 0,11 & 2,8 & 1,2 & 2,0 & 4,1 & 6,1 & 67 \\
\hline C & 5,0 & 0,7 & 2 & 0,09 & 1,0 & 1,0 & 1,8 & 2,1 & 3,9 & 54 \\
\hline
\end{tabular}

Tabela 6 : Resultados de Análise do solo por Ataque Sulfúrico - Perfil $1 /$ Trincheira 1

\begin{tabular}{|c|c|c|c|c|c|c|c|}
\hline & $\overline{\mathrm{SiO}_{2}}$ & $\mathrm{Al}_{2} \mathrm{O}_{3}$ & $\mathrm{Fe}_{2} \mathrm{O}_{3}$ & $\mathrm{TiO}_{2}$ & MnO & & \\
\hline Amostra & \multicolumn{5}{|c|}{$\%$} & $\mathbf{K i}$ & $\mathbf{K r}$ \\
\hline B1 & 6,90 & 4,79 & 0,59 & 0,88 & 0,02 & 2,45 & 2,27 \\
\hline B2 & 8,86 & 6,41 & 0,81 & 1,02 & 0,01 & 2,35 & 2,17 \\
\hline B3 & 7,58 & 6,54 & 0,56 & 1,02 & 0,02 & 1,97 & 1,87 \\
\hline
\end{tabular}

Quanto à identificação do solo do ponto de vista pedológico e de acordo com as mais atualizadas normas de classificação no Brasil (EMBRAPA, 1988), os resultados de análises morfológicas, químicas de rotina e análise por ataque sulfúrico confirmam a existência neste local de propriedades que caracterizam um solo da classe "Pve4" - PODZOLICO VERMELHO-AMARELO ABRÚPTICO EUTRÓFICO Tb A moderado textura arenosa/média fase floresta tropical subperenifolia relevo ondulado.

Com esta identificação, é confirmada a inclusão deste solo na unidade de mapeamento definida no levantamento semi-detalhado (CARVALHO et al, 1997), a qual se estende por este setor da bacia do Córrego do Veado. 
A existência de hoikunte " $B$ " textural é considerada uma condição favorável ao escoamento subsuperficial de água em ocasiões em que o armazenamento neste horizonte atinge o estado de saturação.

Foi aberta uma segunda trincheira, indicada como T2, com metade do seu comprimento de $2,00 \mathrm{~m}$ dentro da área de inundação do ensaio de infiltração, prolongando-se por mais $1,00 \mathrm{~m}$ a jusante desta área (Foto 15). A sua largura e a profundidade medem $1,10 \mathrm{~m}$ e $1,80 \mathrm{~m}$ respectivamente. $O$ solo reconhecido neste segundo perfil é uma extensão do solo analisado em T1, diferenciando-se deste pela maior espessura $(45 \mathrm{~cm})$ do horizonte Ap e pela presença de raízes mais espessas no horizonte $\mathrm{AB}$.

Uma terceira trincheira, designada como T3 e localizada entre as cotas $422 \mathrm{e}$ $425 \mathrm{~m}$, desobstruiu uma surgência, que o terraceamento havia soterrado (Foto 16 ). A base desta trincheira corresponde a uma ruptura do perfil da encosta, onde afloram estratos de lamito compacto, que funcionam como controle estrutural da surgência. A descrição apresentada no Quadro 9 possibilita classificar o solo deste local como podzólico, embora a sua espessura seja muito menor do que a do solo correspondente às trincheiras $\mathrm{T} 1 \mathrm{e} T 2$.

Numa quarta trincheira, designada como T4 e localizada em setor da encosta onde a declividade atinge $45 \%$, identifica-se um solo litólico típico .

Algumas de suas propriedades devem ser consideradas do ponto de vista do comportamento como filtro químico ou bioquímico de substâncias poluentes. A sua capacidade de troca cationica $(T)$ mostra-se de baixa a média para o solo amostrado na trincheira $T 1$, com valores predominantes no intervalo de 5 a $10 \mathrm{meq} / 100 \mathrm{~cm}^{3}$. De acordo com ZUQUETTE \& GANDOLFI (1987), estes valores correspondem a uma eficiência limitada do solo como filtro químico para determinadas substâncias. No entanto, contribuem para atenuar a contaminaçăo da zona saturada de água. especialmente no tocante a metais. Estes valores estão dentro do intervalo daquela: jeterminados para os solos da Bacia do Santo Anastácio (CARVALHO et al , 1997), onde não se registra não se registra nenhum valor elevado $\left(>15 \mathrm{meq} / 100 \mathrm{~cm}^{3}\right)$. 
$\stackrel{8}{\wedge}$
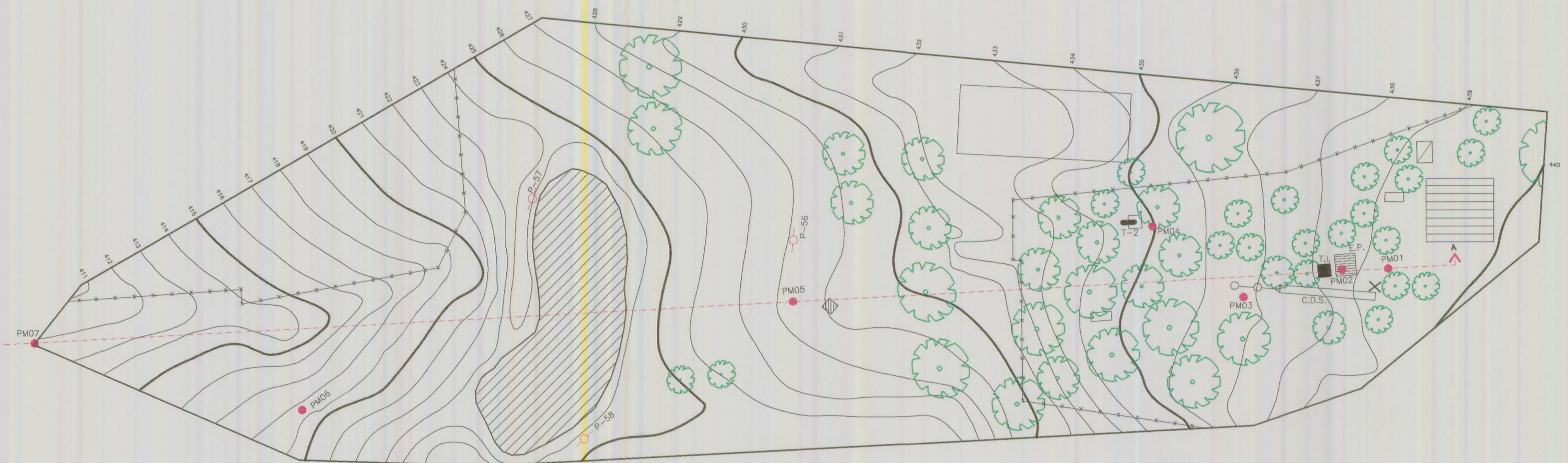

LOCALIZAÇAOO DA AREA

NO CAMPUS DA FCT/UNESP
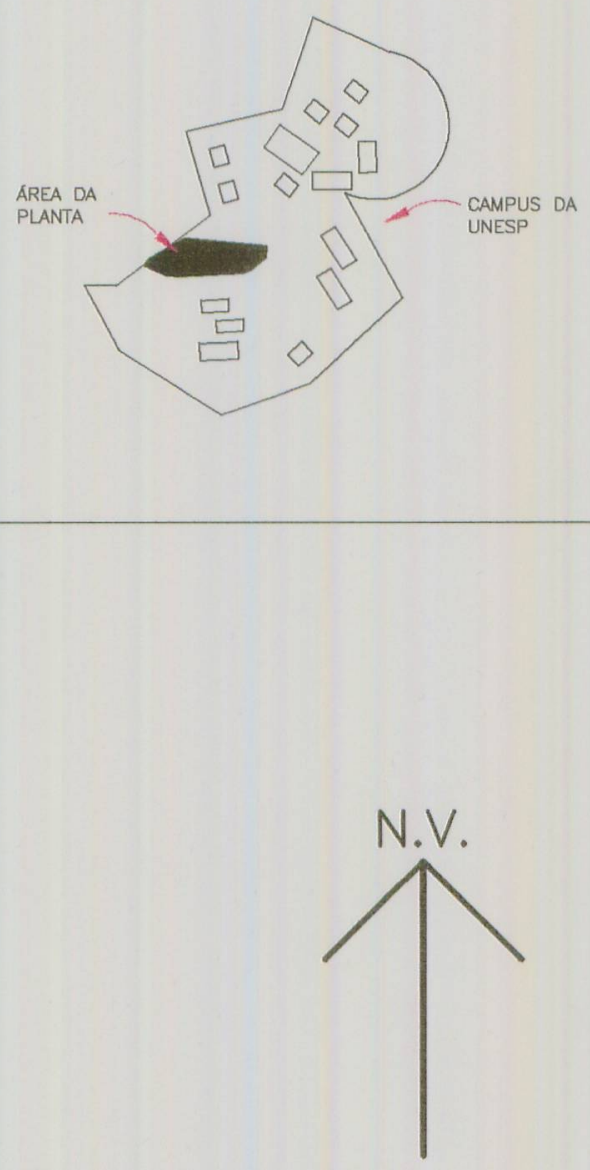

\begin{tabular}{|c|c|c|c|}
\hline \multicolumn{2}{|c|}{ LEGENDA 1} & & LEGENDA 2 \\
\hline \multicolumn{2}{|c|}{1 - COMPONENTES DO CAMPUS } & \multicolumn{2}{|c|}{2 - EQUIPAMENTOS E LOCAIS DE INTERESSE DA PESQUISA } \\
\hline 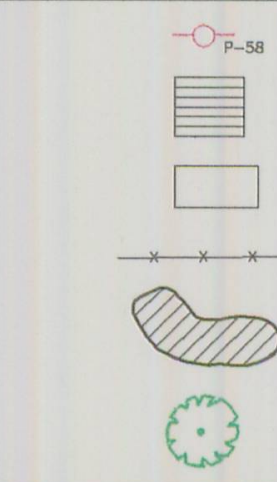 & 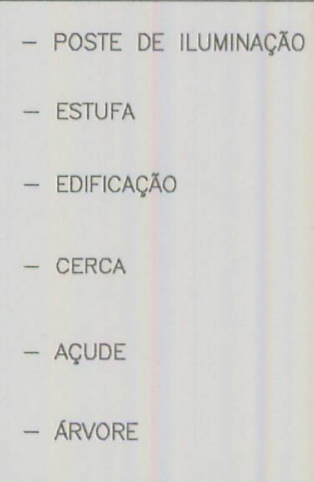 & 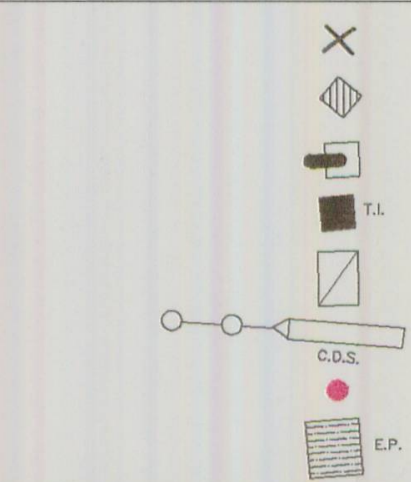 & 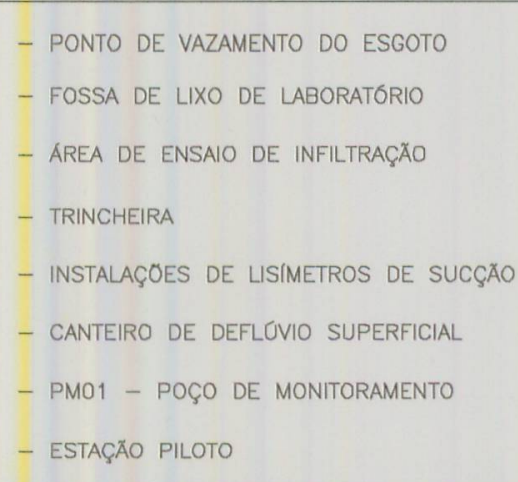 \\
\hline
\end{tabular}

\begin{tabular}{|c|}
\hline FIGURA 19 \\
\hline PLANTA DA AREA DELIMITADA NO LEVANTAMENTO \\
TOPOGRAFICO DE CAMPO \\
ESCALA $1: 1.000$ \\
INTERVALO DE CURVAS DE NIVEL $=1 \mathrm{~m}$ \\
AREA $=32.646,00 \mathrm{~m}^{2}$
\end{tabular}




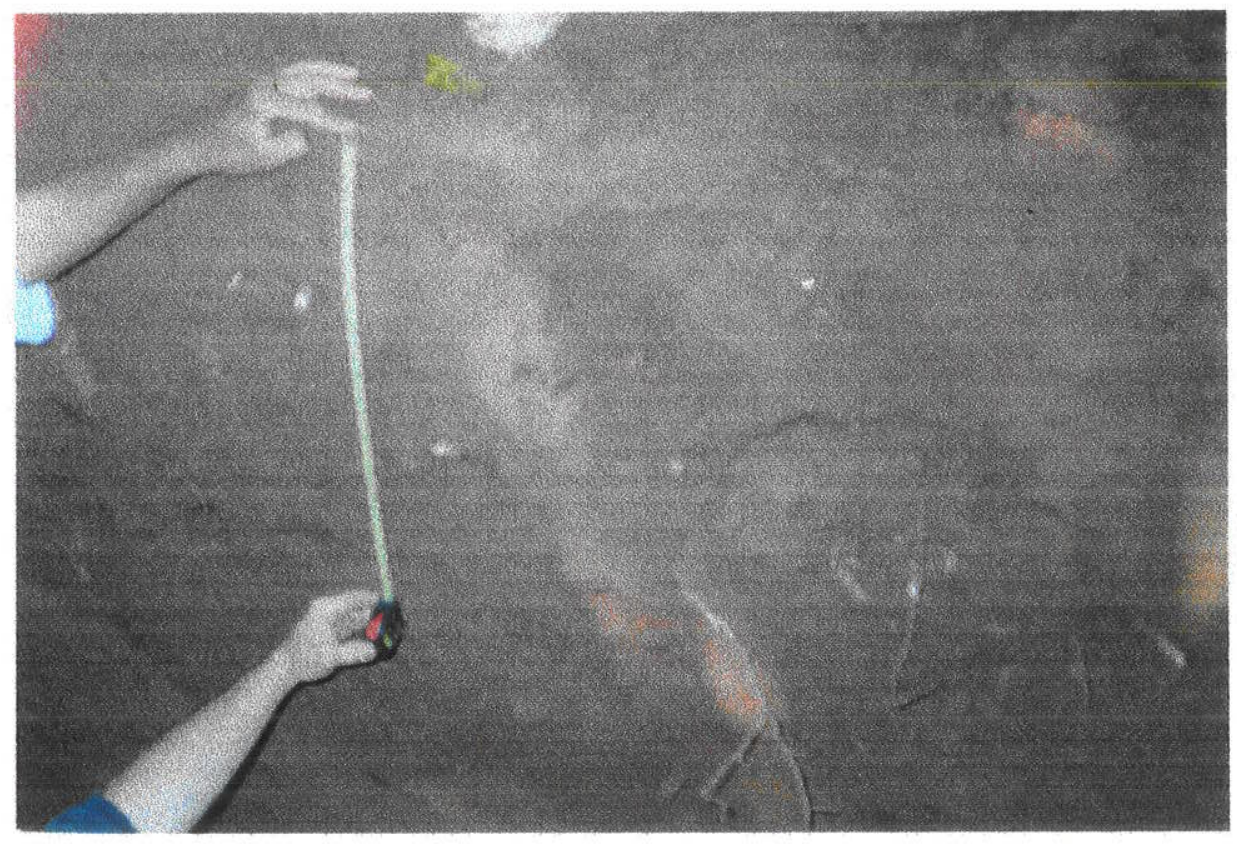

Foto 15: Trincheira T2 - horizonte Ap

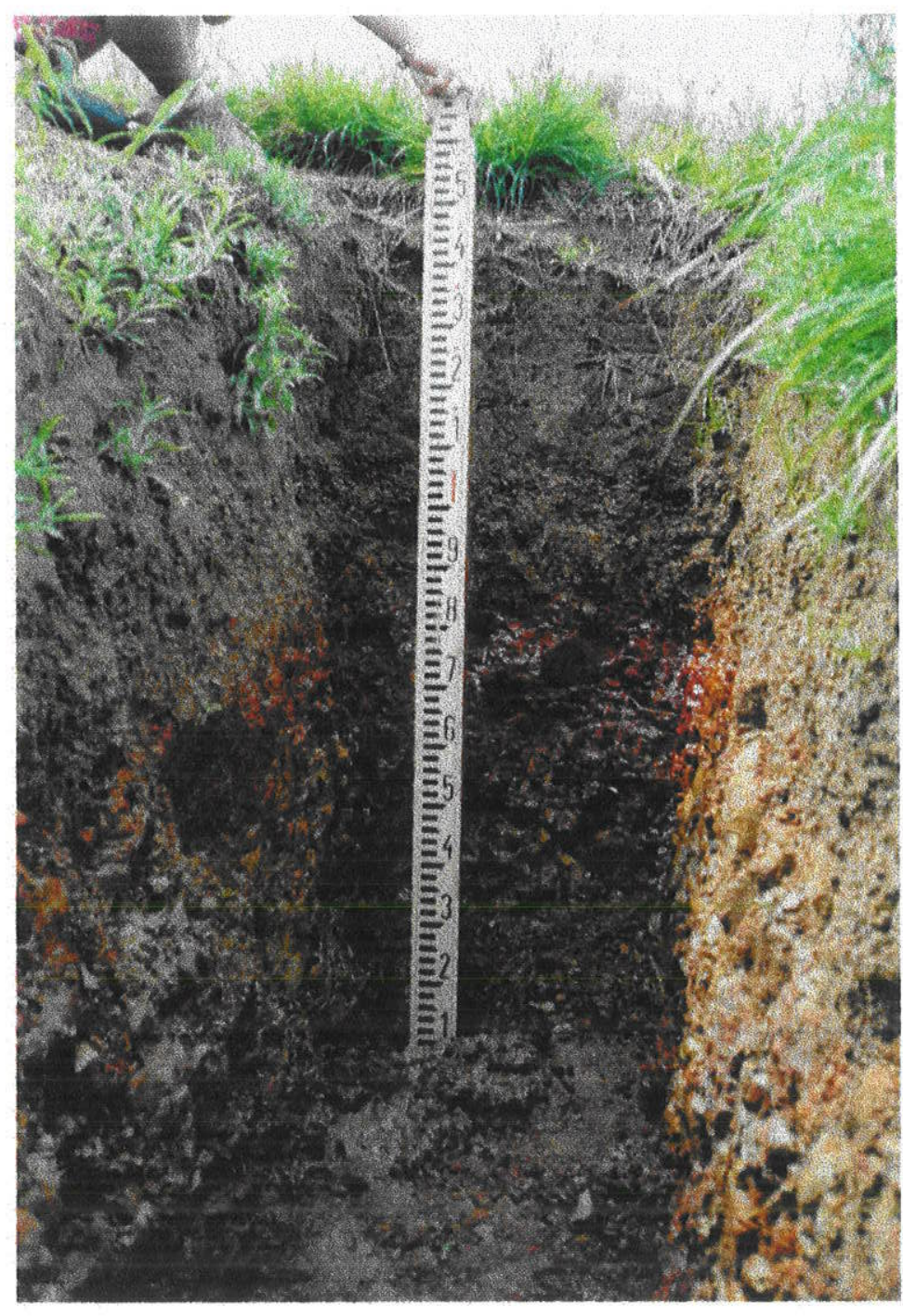

Foto 16: Trincheira T3-perfil do solo, com detalhe da ressudação d'água 


\subsection{PROPRIEDADES DO SOLO RELACIONADAS À ÁGUA}

\subsection{Capacidade de Retenção de Água}

Resultados referentes a esta propriedade para o solo amostrado na trincheira T1 estão resumidos na Tabela 7 e na Figura 20. Observa-se uma diferença destes dados em relação aos valores obtidos anteriormente para um solo podzólico vermelho escuro eutrófico Pee, considerado como típico, de acordo com CARVALHO et al (1996). Verifica-se, no entanto, uma semelhança, entre eles, no padrão de variação da umidade de acordo com a pressão aplicada.

No solo amostrado, a retenção de água é relativamente maior no horizonte $\mathrm{B} 2 \mathrm{t}$ e menor no horizonte Ap, encontrando-se valores intermediários para o horizonte $\mathrm{C}$.

Este gráfico é usado para cálculos de valores de umidade correspondentes às medidas de potencial mátrico obtidas através dos tensiômetros.

\subsubsection{Resultados do Ensaio de Infiltração}

As Tabelas 8,9 e 10 e as Figuras 21 e 22 resumem a evolução da infiltração da água nos diferentes horizontes do solo.

Distingue-se uma primeira etapa do ensaio, referente ao tempo decorrido entre 7:38 h e 8:20 $\mathrm{h}$, quando foi interrompida a operação de manutenção do nível estabelecido da lâmina de água. Foi constatada a existência de sorvedouro junto a dois cantos da área isolada para a inundação, devido à presença de cavidades de raízes mortas entre 20 e $25 \mathrm{~cm}$ de profundidade, ou seja, pouco abaixo do limite inferior da barragem de madeira utilizada para isolar a área de inundação. O valor de $\mathrm{K}$ variou de $6,93 \cdot 10^{-3} \mathrm{~cm} / \mathrm{s}$ a $5,21 \cdot 10^{-3} \mathrm{~cm} / \mathrm{s}$.

Calculando-se o balanço de água pela diferença do volume de água utilizada $e$ os valores obtidos com referência ao acréscimo de água no solo, verifica-se uma fuga de água de $374,87 \mathrm{~L}$, que é a soma de perda através das cavidades e do efeito de bordadura. Dada a magnitude do valor de fuga de água, a parcela correspondente ao efeito de bordadura é muito reduzida. Deduz-se que mais de $300 \mathrm{~L}$ de água foi desviada pelas cavidades. 
Tabela 7 Retenção de água no solo -

Trincheira T1

\begin{tabular}{|c|c|c|c|}
\hline PRESSAOO & \multicolumn{3}{|c|}{ UMIDADE } \\
\hline$(\mathrm{m})$ & $\mathrm{A}_{\mathrm{P}}$ & $\mathrm{B} 2$ & $\mathrm{C}$ \\
\hline $\mathbf{0}$ & 41,29 & 42,66 & 47,63 \\
\hline $\mathbf{1}$ & 19,72 & 26,3 & 24,94 \\
\hline $\mathbf{3}$ & 12,77 & 21,2 & 16,27 \\
\hline $\mathbf{1 0}$ & 13,34 & 19,07 & 14,81 \\
\hline $\mathbf{5 0}$ & 7,7 & 18,51 & 14,65 \\
\hline $\mathbf{1 5 0}$ & 7,71 & 15,41 & 11,04 \\
\hline
\end{tabular}

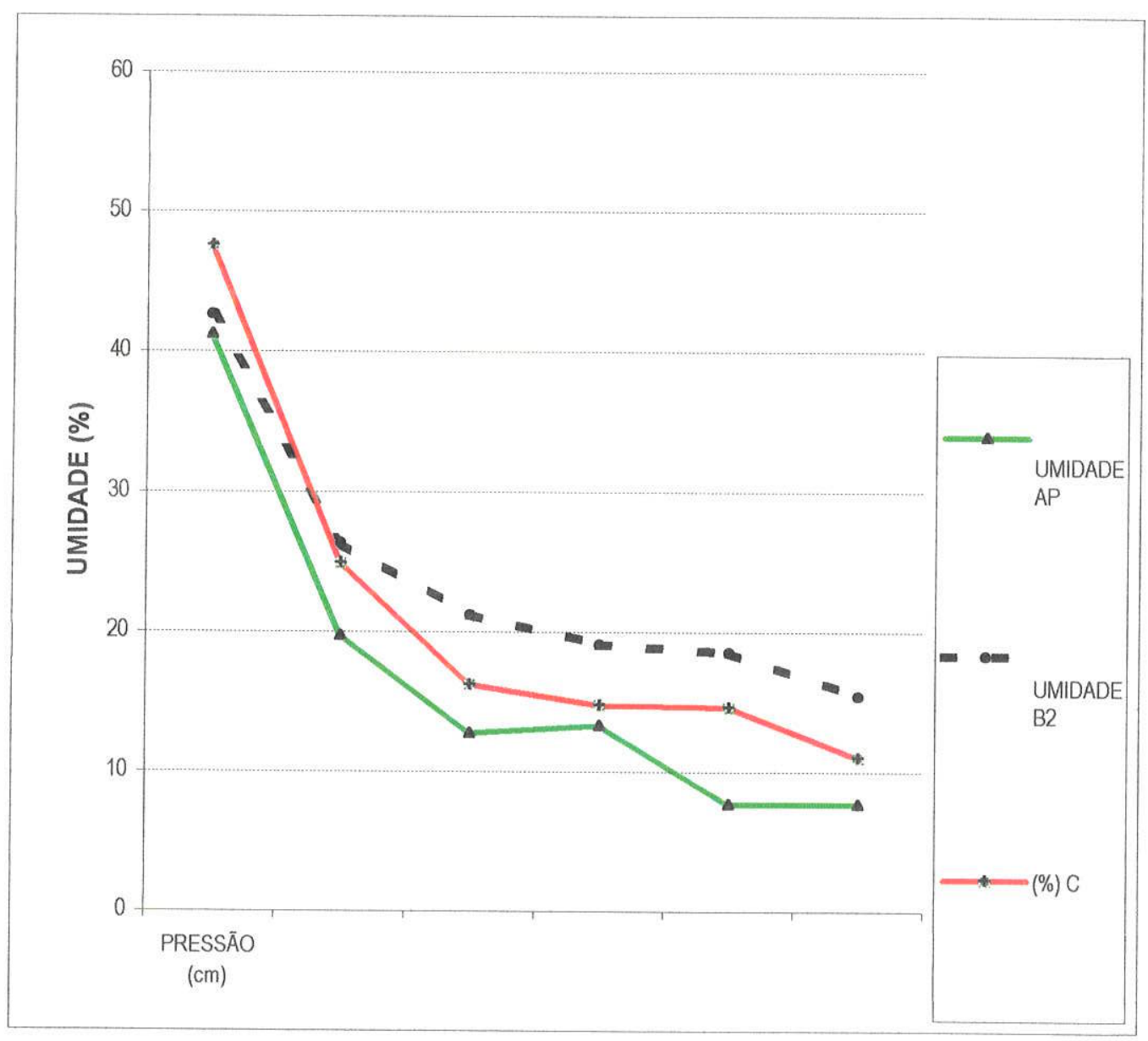

Figura $2 C$ : Curva de retenção de água - trincheira $\mathrm{T} 1$ 
Na retomada do ensaio, a inundaçăo foi mantida das 10:08h até as 14:20 h, quando foi encerrado o ensaio, devido ao acontecimento de fuga de água novamente. Um terceiro sorvedouro apareceu, de modo concentrado, em cavidade de raiz morta. Devido a este contratempo, considera-se válida de infiltração até 13:23h, quando foi tomada a penúltima medida de adição de água. $O$ valor de condutividade hidráulica no horizonte superficial variou de $1,12 \cdot 10^{-3}$ a $2,38 \cdot 10^{-4}$. A oscilação de valores verificada nas 2 últimas medidas consideradas válidas revela a influência da atuação do sorvedouro (Figura 21).

Tabela 8: Ensaio de infiltração - estimativa de permeabilidade 1a. etapa

\begin{tabular}{|c|c|c|c|c|c|c|c|c|}
\hline TAMBOR & $\begin{array}{r}\Sigma T E M P O \\
(\min )\end{array}$ & $\begin{array}{c}\text { TEMPO } \\
(\mathbf{s})\end{array}$ & $\begin{array}{c}\Sigma T E M P O \\
(\mathbf{s})\end{array}$ & $\begin{array}{c}\Sigma Q \\
(\mathbf{l})\end{array}$ & $\begin{array}{c}\mathbf{Q} \\
\left(\mathrm{cm}^{3}\right)\end{array}$ & $\begin{array}{c}\Sigma Q \\
\left(\mathrm{~cm}^{3}\right)\end{array}$ & $\begin{array}{c}\text { A } \\
\left(\mathrm{cm}^{2}\right)\end{array}$ & $\begin{array}{c}\mathrm{K} \\
(\mathrm{cm} / \mathrm{s})\end{array}$ \\
\hline 1 & 0 & 0 & 0 & 0 & 0 & 0 & 39528,76 & \\
\hline 1 & 12 & 720 & 720 & 197,19 & 197194,31 & 197194,3 & 39528,76 & $6,93 \mathrm{E}-03$ \\
\hline 2 & 27 & 900 & 1620 & 390,82 & 193630,55 & 390824,9 & 39528,76 & $5,44 \mathrm{E}-03$ \\
\hline 3 & 42 & 900 & 2520 & 576,14 & 185315,13 & 576140 & 39528,76 & $5,21 \mathrm{E}-03$ \\
\hline
\end{tabular}

Pela análise dos valores de umidade relativos aos vários niveis de medição, distinguem-se 2 zonas, uma delas localizada abaixo da profundidade de $105 \mathrm{~cm}$ e outra sobreposta a ela. Na zona superior, houve aumento temporário ou crescente de umidade; na zona inferior, com exceção de um valor relativo à profundidade de $100 \mathrm{~cm}$, alcançada no dia seguinte ao da inundação, não se verifica aumento de umidade. Tendo sido mantida, a todos as profundidades consideradas, uma taxa de umidade maior que a correspondente à capacidade de campo, a condição básica de drenagem persistiu através de todo o perfil analisado. A interpretação dos dados colhidos nos 3 dias de duração do ensaio possibilita a identificação de uma barreira à percolação no horizonte B2 textural. 
Tabela 9: Ensaio de infiltração - retomada

estimativa da permeabilidade

$K(0)$

\begin{tabular}{|c|c|c||c|c|}
\hline $\begin{array}{r}\text { HORÁRIO } \\
(\mathbf{h})\end{array}$ & $\begin{array}{c}\text { TEMPO } \\
\text { (s) }\end{array}$ & $\begin{array}{c}\text { Q } \\
\left(\mathrm{cm}^{3}\right)\end{array}$ & $\begin{array}{c}\text { A } \\
\left(\mathrm{cm}^{3}\right)\end{array}$ & $\begin{array}{c}\mathrm{K} \\
\text { (cm/s) }\end{array}$ \\
\hline 9,23 & & 0 & 39528,76 & \\
\hline 9,30 & 420 & 18650,89 & 39528,76 & $1,12 \mathrm{E}-03$ \\
\hline 12,05 & 9300 & 167711,30 & 39528,76 & $4,56 \mathrm{E}-04$ \\
\hline 12,43 & 2280 & 20335,46 & 39528,76 & $2,26 \mathrm{E}-04$ \\
\hline 13,23 & 2400 & 22570,43 & 39528,76 & $2,38 \mathrm{E}-04$ \\
\hline
\end{tabular}

$\mathrm{Q}(\mathrm{L} / \mathrm{min}$.

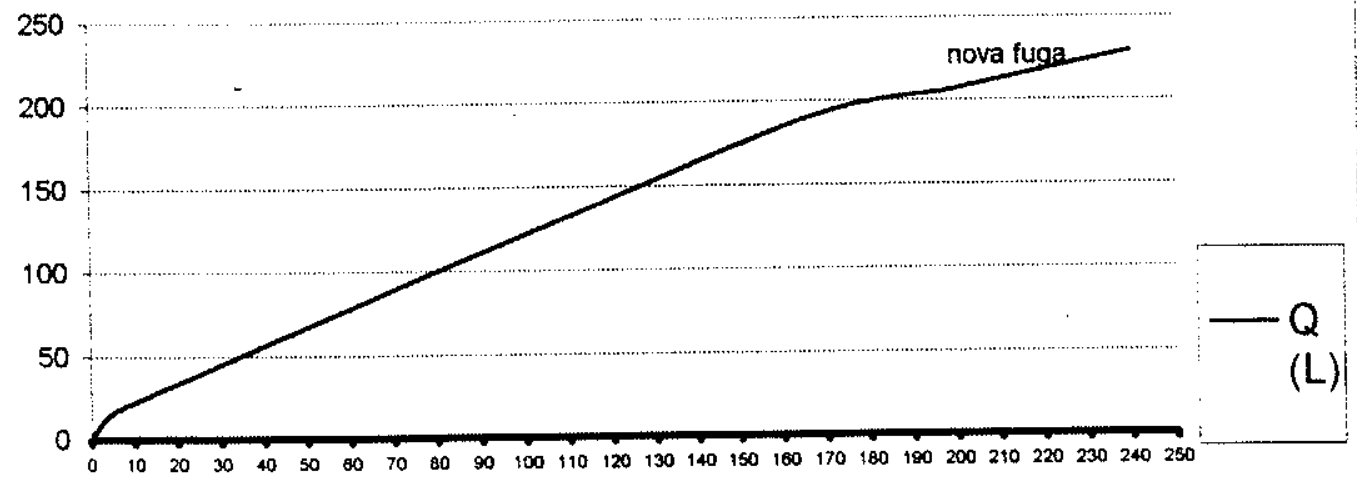

Figura 21: Ensaio de infiltração - Gráfico infiltração $\times$ tempo 
Tabela 10: Ensaio de infiltração - cálculo de umidade por massa

\begin{tabular}{|c|c|c|c|c|c|c|c|c|c|}
\hline AM. & FURO & $\begin{array}{l}\text { PROF. } \\
\text { (cm) }\end{array}$ & DIA & $\begin{array}{c}\text { HORA } \\
\text { (h) }\end{array}$ & $\begin{array}{c}\mathrm{Va} \\
\left(\mathrm{cm}^{3}\right)\end{array}$ & $\begin{array}{c}M_{\text {sol }} \\
\text { (g) }\end{array}$ & $\mathbf{U}$ & $\begin{array}{l}\text { U } \\
\%\end{array}$ & $\begin{array}{c}\text { U-CC } \\
\%\end{array}$ \\
\hline 1 & 1 & $20-25$ & $1^{\circ}$ & 13,30 & 6,96 & 38,31 & 0,18 & 1817 & 9,05 \\
\hline 2 & 2 & $40-45$ & $1^{\circ}$. & 13,33 & 12,3 & 65,97 & 0,19 & 18,57 & 9,05 \\
\hline 3 & 3 & $60-65$ & $1^{\circ}$ & 13,38 & 6,73 & 42,15 & 0,16 & 15,97 & \\
\hline 4 & 4 & $80-85$ & $1^{\circ}$ & 13,45 & 7,83 & 58,7 & 0,13 & 13,34 & \\
\hline 5 & 5 & $100-105$ & $1^{\circ}$ & 14,00 & 8,55 & 68,24 & 0,13 & 12,53 & 14,96 \\
\hline 6 & 6 & $150-155$ & $1^{\circ}$ & 14,20 & 2,95 & 29,24 & 0,10 & 10,09 & \\
\hline 7 & 7 & 6965 & $1^{\circ}$. & 14,40 & 9,33 & 54,51 & 0,17 & 1712 & \\
\hline 8 & 8 & $100-105$ & $1^{\circ}$ & 14,50 & 8,77 & 61,96 & 0,14 & 1415 & 12,93 \\
\hline & & & $1^{\circ}$ & 7,38 & & & & & \\
\hline & 1 & $20-25$ & $2^{\circ}$ & 10,08 & & \multicolumn{3}{|c|}{ SATURADO } & 9,05 \\
\hline 9 & 2 & $40-45$ & $2^{\circ}$ & 10,08 & 8,69 & 41,35 & 0,21 & 21,02 & 9,05 \\
\hline 10 & 3 & $60-65$ & $2^{\circ}$ & 10,09 & 6,24 & 39,04 & 0,16 & 15,98 & \\
\hline 11 & 4 & $80-85$ & $2^{\circ}$ & 10,10 & 6,11 & 52,14 & 0,12 & 11,72 & \\
\hline 12 & 5 & $100-405$ & $2^{\circ}$ & 10,12 & 3,63 & 37,14 & 0,10 & 9,77 & 14,96 \\
\hline 13 & 6 & 150.155 & $2^{\circ}$ & 10,13 & 3,71 & 38,81 & 0,10 & 9,56 & 12,93 \\
\hline & 1 & $20-25$ & $2^{\circ}$ & 11,35 & & \multicolumn{3}{|c|}{ SATURADO } & 9,05 \\
\hline 14 & 2 & $40-45$ & $2^{\circ}$ & 11,35 & 16,1 & 60,37 & 0,27 & 26,70 & 9,05 \\
\hline 15 & 3 & $60-65$ & $2^{\circ}$ & 11,37 & 6,29 & 38,25 & 0,16 & 16.44 & \\
\hline 16 & 4 & $80-85$ & $2^{\circ}$ & 11,38 & 7,48 & 67,04 & 0,11 & 11,16 & \\
\hline 17 & 5 & $100-105$ & $2^{\circ}$ & 11,38 & 7,26 & 68,25 & 0,11 & 10,64 & 14,96 \\
\hline 18 & 6 & $150-155$ & $2^{\circ}$ & 11,40 & 3,5 & 34,3 & 0,10 & 10,20 & 12,93 \\
\hline & 1 & $20-25$ & $2^{\circ}$ & 14,30 & \multicolumn{3}{|c|}{ SATURADO } & & 9,05 \\
\hline 19 & 2 & $40-45$ & $2^{\circ}$ & 14,30 & 16,34 & 58,37 & 0,28 & 2798 & 9,05 \\
\hline 20 & 3 & $60-65$ & $2^{\circ}$ & 14,31 & 14,28 & 58,17 & 0,25 & 24.55 & \\
\hline 21 & 4 & $80-85$ & $2^{\circ}$ & 14,32 & 5,30 & 25,52 & 0,21 & 2077 & \\
\hline 22 & 5 & $100-105$ & $2^{\circ}$ & 14,33 & 2,77 & 27,22 & 0,10 & 10,18 & 14,96 \\
\hline 23 & 6 & $150-155$ & $2^{\circ}$ & 14,34 & 1,47 & 14,82 & 0,10 & 9,92 & 12,93 \\
\hline & 1 & $20-25$ & $2^{\circ}$ & 16,35 & \multicolumn{3}{|c|}{ SATURADO } & & 9,05 \\
\hline 24 & 2 & $40-45$ & $2^{0}$ & 16,35 & 12,55 & 48,44 & 0,26 & 25,91 & \\
\hline 25 & 3 & $60-65$ & $2^{\circ}$ & 16,36 & 13,3 & 53,87 & 0,25 & 2467 & \\
\hline 26 & 4 & $80-85$ & $2^{\circ}$ & 16,37 & 16,1 & 61,98 & 0,26 & 26,04 & \\
\hline 27 & 5 & $100-105$ & $2^{\circ}$ & 16,38 & 3,9 & 38,91 & 0,10 & 10,02 & 14,96 \\
\hline 28 & 6 & $150-155$ & $2^{\circ}$ & 16,39 & 5,54 & 53,76 & 0,10 & 10,31 & 12,93 \\
\hline 29 & 7 & 60.65 & $2^{\circ}$ & 16,41 & 3,45 & 22,68 & 0,16 & 1521 & \\
\hline 30 & 8 & $100-105$ & $x^{2}$ & 16,12 & 3,28 & 28,6 & 0,11 & 11,47 & 14,96 \\
\hline 31 & 1 & $20-25$ & $3^{\circ}$ & 8,05 & 18,1 & 72,68 & 0,25 & 2498 & 9,05 \\
\hline 32 & 2 & $40-45$ & $3^{\circ}$ & 8,06 & 4,44 & 17,85 & 0,25 & 2487 & \\
\hline 33 & 3 & $60-65$ & $3^{\circ}$ & 8,07 & 7,21 & 29,72 & 0,24 & 24,26 & \\
\hline 34 & 4 & $80-85$ & $3^{\circ}$ & 8,08 & 10,8 & 46,16 & 0,23 & 23,40 & \\
\hline 35 & 5 & $100-105$ & $3^{\circ}$ & 8,09 & 1,91 & 19,53 & 0,10 & 9,78 & 14,96 \\
\hline 36 & 6 & $150-155$ & $3^{\circ}$. & 8,10 & 2,42 & 21,89 & 0,11 & 11,06 & 12,93 \\
\hline 37 & 7 & 6065 & $3^{\circ}$ & 8,12 & 2,39 & 20,83 & 0,11 & 11,47 & \\
\hline 38 & 8 & $100-105$ & $3^{\circ}$ & 8,13 & 4,57 & 20,2 & 0,16 & $16 \% 21$ & 14,96 \\
\hline
\end{tabular}

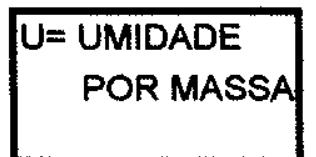

U-CC UMIDADE

DA CAPA-

CIDADE

DE CAMPO

FORA
DA AREA
DE INUN
DACAO

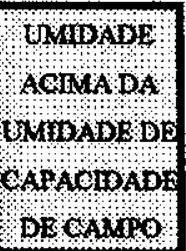


Tabela 11: Ensaio de infiltraçăo - cálculo de umidade por volume - amostras deformadas

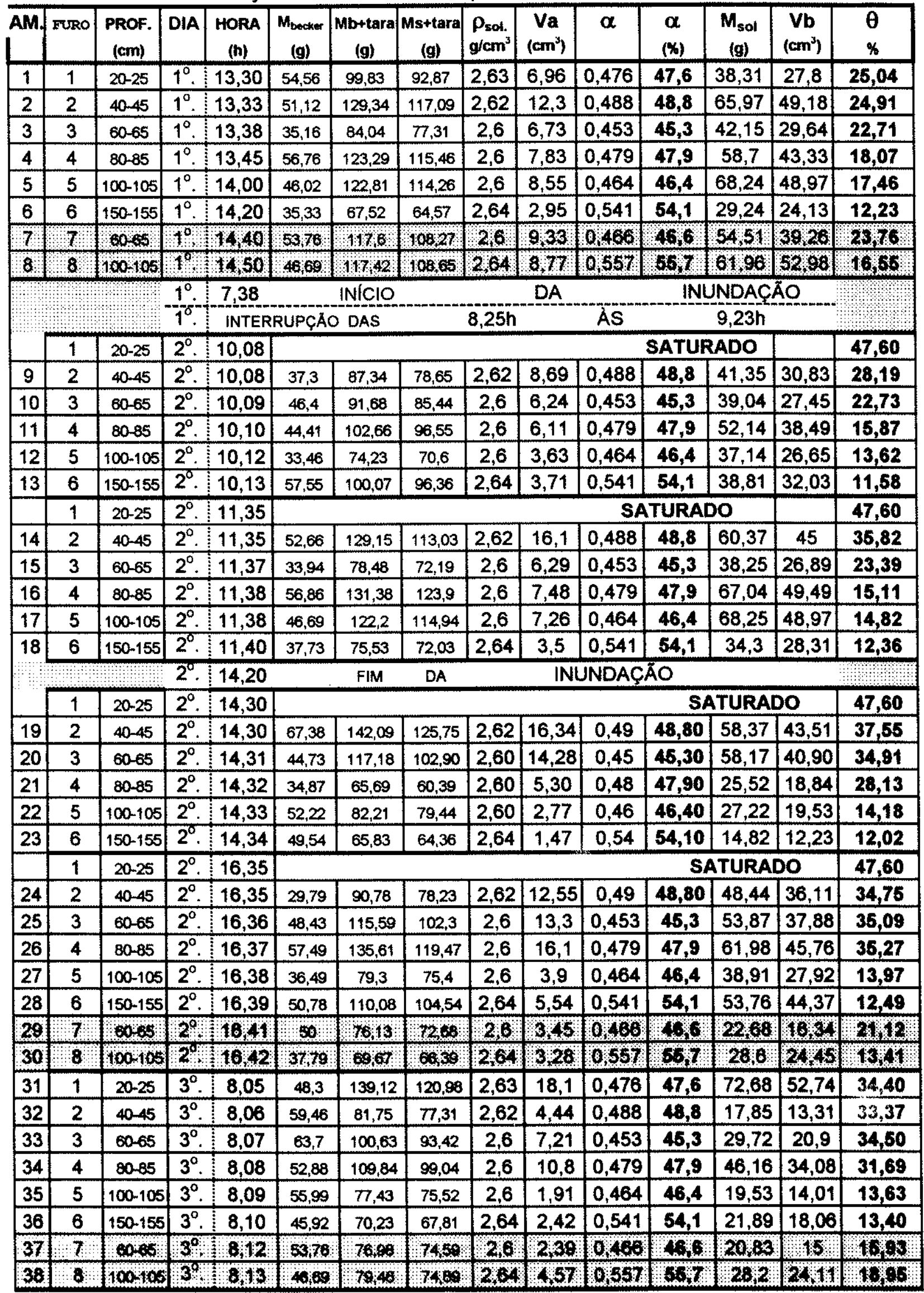


Tabela 12: Ensaio de infiltração - cálculo de umidade - amostras indeformadas

\begin{tabular}{|c|c|c|c|c|c|c|c|c|c|c|c|c|c|c|c|}
\hline Am. & DIA & $\begin{array}{c}\text { HORA } \\
\text { (h) }\end{array}$ & $\begin{array}{c}\text { TRINCHEIRA } \\
\text { PROF.(cm) }\end{array}$ & $\begin{array}{c}\text { Mbecker } \\
\text { (g) }\end{array}$ & $\begin{array}{c}\text { Manel } \\
\text { (g) }\end{array}$ & $\begin{array}{l}V_{\text {anel }} \\
\mathrm{cm} 3 \\
\end{array}$ & $\begin{array}{c}\text { Mb+tara } \\
\text { (g) } \\
\end{array}$ & $\begin{array}{c}\text { Msttara } \\
(g) \\
\end{array}$ & $\begin{array}{c}\rho s \\
\mathrm{~g} / \mathrm{cm}^{3} \\
\end{array}$ & $\begin{array}{l}\mathrm{mb} \\
(\mathrm{g})\end{array}$ & $\begin{array}{l}\mathrm{ms} \\
(\mathrm{g}) \\
\end{array}$ & $\begin{array}{c}\text { Vsol } \\
\mathrm{cm}^{3} \\
\end{array}$ & $\alpha$ & $\begin{array}{l}\alpha \\
\% \\
\end{array}$ & $\%$ \\
\hline 39 & $3^{\circ}$ & 9,1 & $1: 20$ & 68,44 & 27,6 & 52,05 & 156,25 & 140,13 & 2,63 & 87,81 & 71,69 & 27,259 & 0,48 & 47,63 & 30,97 \\
\hline 40 & $3^{\circ}$ & 9,13 & $1: 40$ & 64,06 & 27,6 & 52,05 & 150,43 & 133,89 & 2,62 & 86,37 & 69,83 & 26,653 & 0,49 & 48,79 & 31,78 \\
\hline 41 & $3^{\circ}$ & 9,2 & $1: 60$ & 65,07 & 29,06 & 52,05 & 155,04 & 139,06 & 2,6 & 89,97 & 73,99 & 28,458 & 0,45 & 45,33 & 30,70 \\
\hline 42 & $3^{\circ}$ & 9,2 & $1: 80$ & 77,15 & 29,06 & 52,05 & 162,56 & 147,72 & 2,6 & 85,41 & 70,57 & 27,142 & 0,48 & 47,85 & 28,51 \\
\hline 43 & $3^{\circ}$ & 10,35 & $1: 100$ & 63,72 & 27,6 & 52,05 & 147,39 & 136,29 & 2,6 & 83,67 & 72,57 & 27,912 & 0,46 & 46,38 & 21,33 \\
\hline 44 & $3^{\circ}$ & 11,2 & I: 120 & 66,81 & 27,6 & 52,05 & 144,09 & 136,57 & 2,62 & 77,28 & 69,76 & 26,626 & 0,49 & 48,85 & 14,45 \\
\hline 45 & $3^{\circ}$ & 11,2 & $1: 160$ & 80,87 & 27,6 & 52,05 & 150,22 & 144 & 2,64 & 69,35 & 63,13 & 23,913 & 0,54 & 54,06 & 11,95 \\
\hline 46 & $3^{\circ}$ & 14,15 & $E: 20$ & 113,12 & 27,6 & 52,05 & 184,65 & 174 & 2,63 & 71,53 & 60,88 & \begin{tabular}{|l|}
23,148 \\
\end{tabular} & 0,56 & 55,53 & 20,46 \\
\hline 47 & $3^{\circ}$ & 14,2 & E: 40 & 106,95 & 27,6 & 52,05 & 190,99 & 176,72 & 2,62 & 84,04 & 69,77 & 26,63 & 0,49 & 48,84 & 27,42 \\
\hline 48 & $3^{\circ}$ & 14,23 & E: 60 & 68,14 & 27,6 & 52,05 & 152,5 & 140,43 & 2,6 & 84,36 & 72,29 & 27,804 & 0,47 & 46,58 & 23,19 \\
\hline 49 & $3^{\circ}$ & 14,26 & E: 80 & 73,95 & 27,6 & 52,05 & 145,86 & 138,4 & 2,6 & 71,91 & 64,45 & 24,788 & 0,52 & 52,38 & 14,33 \\
\hline 50 & $3^{\circ}$ & 14,31 & $E: 100$ & 93,83 & 27,6 & 52,05 & 161,33 & 155,38 & 2,6 & 67,5 & 61,55 & 23,673 & 0,55 & 54,52 & 11,43 \\
\hline 51 & $3^{\circ}$ & 14,34 & $E: 120$ & 54,51 & 27,6 & 52,05 & 128,31 & 119,68 & 2,62 & 73,8 & 65,17 & 24,874 & 0,52 & 52,21 & 16,58 \\
\hline 52 & $3^{\circ}$ & 14,4 & $E: 160$ & 52,05 & 27,6 & 52,05 & 119,09 & 112,87 & 2,64 & 67,04 & 60,82 & 23,038 & 0,56 & 55,74 & 11,95 \\
\hline 53 & $3^{\circ}$ & 14,45 & RAIZ-48 & 66,56 & 27,6 & 52,05 & 149,52 & 135,23 & 2,6 & 82,96 & 68,67 & 26,412 & 0,49 & 49,26 & 27,46 \\
\hline 54 & $3^{\circ}$ & 14,49 & RAIZ-48 & 56,68 & 27,6 & 52,05 & 140,92 & 124,63 & 2,3 & 84,24 & 67,95 & 26,135 & 0,50 & 49,79 & 31,30 \\
\hline 55 & $3^{\circ}$ & 14,52 & RAIZ-61,5 & 66,1 & 27,6 & 52,05 & 140,99 & 133,6 & 2,6 & 74,89 & 67,5 & 25,962 & 0,50 & 50,12 & 14,20 \\
\hline 56 & $3^{\circ}$ & 14,59 & RAIZ-70,5 & & 27,6 & 52,05 & 118,4 & 101,59 & 2,6 & 90,8 & 73,99 & 28,458 & 0,45 & 45,33 & 32,39 \\
\hline 57 & $3^{\circ}$ & 15,03 & RAIZ-61,5 & 66,1 & 28,72 & 51,18 & 103,61 & 96,08 & 2,6 & 74,89 & 67,36 & 25,908 & 0,49 & 49,38 & 14,71 \\
\hline 58 & $3^{\circ}$ & 15,05 & RAIZ-77 & & 28,72 & 51,18 & 106,19 & 99,04 & 2,6 & 77,47 & 70,32 & 27,046 & 0,47 & 47,15 & 13,97 \\
\hline
\end{tabular}

I=TRINCHEIRA 2 - AREA INUNDADA

$E=$ TRINCHEIRA 2 - A JUSANTE DA AREA INUNDADA

$M_{\text {BECKER }}=$ TARA DO COPO DE BECKER

$M_{\text {ANEL }}=$ TARA DO ANEL DE AMOSTRAGEM

$V_{\text {ANEL }}=$ VOLUME INTERNO DO ANEL
$M b=$ MASSA DE SÓLIDOS + MASSA DE AGUA CONTIDA $M s=$ MASSA DE SOLO SECO

$\rho_{\mathrm{s}}=$ MASSA ESPECÍFICA DOS SÓLIDOS $\alpha=$ POROSIDADE

$\theta=$ UMIDADE EM VOLUME $\left(\mathrm{cm}^{3} / \mathrm{cm}^{\circ}\right)$ CONCENTRAÇAO DE UMIDADE 


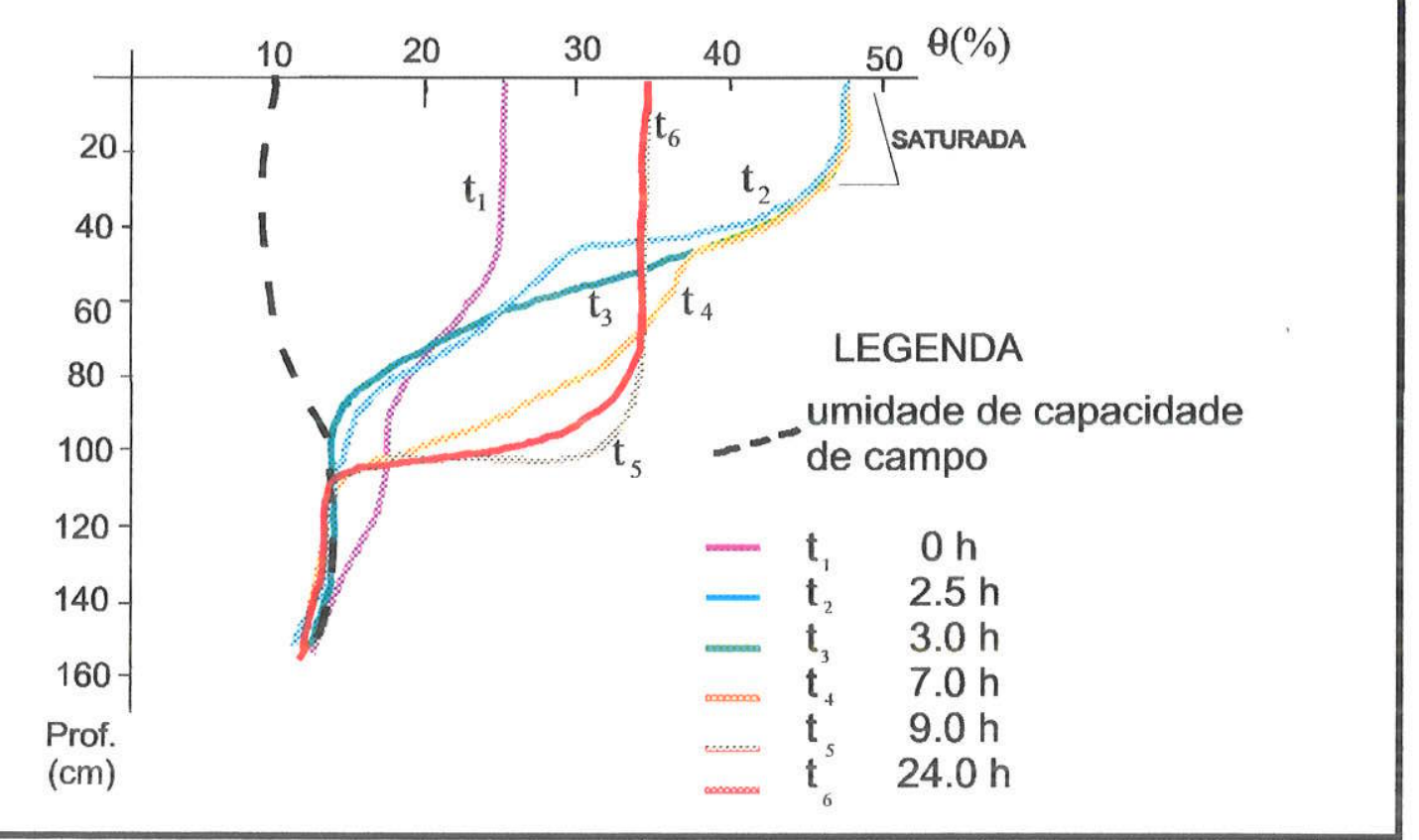

Figura 22: Gráfico umidade X profundidade em tempos diferentes durante e após a inundação.

Trata-se de uma barreira moderadora da percolação. O fluxo é retardado, mas não impedido de todo. Em período de 5 dias em solo arenoso e de 1 semana em solo argiloso, conforme o grau de umidade do solo, a drenagem devida a um evento de precipitação ultrapassa esta barreira e atinge o limite inferior do perfil, que em geral é considerado até 2 $m$ de profundidade (REICHARDT, 1988).

Para se constatar a existência de escoamento subsuperficial, foi analisada a evolução dos valores de umidade relativos ao setor da trincheira localizado a jusante da área inundada, referidos na Tabela 12 pela letra "E". Não se distingue, em análise de correlação de diferentes profundidades, um contraste entre a umidade medida anteriormente à introdução da água para o ensaio e a umidade medida posteriormente ao ensaio. Deduz-se que não houve condição de quantidade suficiente de água introduzida no solo, de declive do limite entre horizontes e de tempo de redistribuição de água, para se verificar a ocorrência deste fenômeno. 


\subsubsection{Determinação da Condutividade Hidráulica}

A dificuldade de saturar o solo por todo o perfil, devido à perda de água por cavidades de raízes, foi um obstáculo decisivo à execução de ensaios para determinação da condutividade hidráulica. No ensaio de infiltração, obteve-se um resultado que pode ser representativo, com restrições, da condutividade hidráulica do horizonte superficial.

Para uma interpretação comparativa, foi adotada a classificação proposta por WISCHMEIER et al (1971), sendo então diferenciados os horizontes do solo podzólico identificado nas trincheiras 1 e 2 , em ordem decrescente de condutividade, conforme é abaixo apresentado :
$1^{\circ}$.) horizonte Ap
$2^{\circ}$.) horizonte $A B$
$3^{\circ}$.) horizonte $\mathrm{C}$
$4^{\circ}$.) horizonte $\mathrm{BC}$
$5^{\circ}$.) horizonte $\mathrm{B} 1 \mathrm{t}$
$6^{\circ}$.) horizonte $\mathrm{B} 2 \mathrm{t}$

\subsection{RESULTADOS REFERENTES A DADOS DE MONITORAMENTO}

\subsubsection{Resultados Referentes à Variação do Potencial de Água no Solo}

Nas tabelas referentes a dados obtidos através dos tensiômetros e dos blocos de gesso, a notação adotada para valores de potencial mátrico é a do Sistema Internacional de Unidades, onde se recomenda a apresentação de medida em Pascal ( $\mathrm{Pa}$ ) e derivados. No caso presente, opta-se pela unidade de Hectopascal ( $\mathrm{Hpa}$ ), por possibilitar que sejam compatibilizadas, em gráficos, as escalas das variáveis referentes ao potencial do solo e à precipitação total por semana. 


\section{A - Resultados dos tensiômetros}

A análise dos resultados (Tabelas 13,14 e 150 e dos gráficos correspondentes (Figuras 23, 24 e 25), onde estão combinados valores obtidos COM os tensiômetros a diferentes profundidades do solo e os registros de precipitação, aponta um comportamento irregular do potencial mátrico no período de monitoramento considerado.

O ano de 1996 apresenta uma variação sazonal que se desvia menos do que é considerado característica desta zona climática, onde o período de agosto a setembro é o de clímax da estiagem, da insolação e da evaporação, tendo sido nesse ano registrado uma antecipação para junho do período de estiagem acentuada. Para o mesmo ano de 1996, no entanto, foi sendo constatado nos valores potencial mátrico, com indicação da correspondente variação de umidade, um comportamento de resposta rápida à profundidade de $0,20 \mathrm{~m}$, a eventos de precipitação de duração de alguns dias e um comportamento de relativa estabilização do potencial mátrico e da umidade a mais de $1 \mathrm{~m}$ de profundidade nas mesmas ocasiões desses eventos.

No ano de 1997, de 22 de maio a 29 de junho, a pluviosidade foi excepcional, como se confere em tabela do Anexo 2, registrando-se a precipitação de $238,7 \mathrm{~mm}$ no mês de junho. As medidas de potencial mátrico indicaram resposta rápida a $0,20 \mathrm{~m}$ de profundidade, mas também uma extensão da influência da pluviosidade muito elevada a profundidades superiores a $1 \mathrm{~m}$.

Os resultados de potencial mátrico do solo, obtidos através dos tensiômetros em 1996, 1997 e 1998, são analisados com base no potencial de capacidade de campo, adotando-se o limite de $-1 / 3 \mathrm{~atm}$ ou $-327 \mathrm{HPa}$, abaixo do qual a drenagem através do perfil é mínima.

De acordo com os dados dos tensiômetros, durante todo o ano de 1996, a $1 \mathrm{~m}$ e a $1,5 \mathrm{~m}$ de profundidade, o solo apresentou sempre valores de potencial mátrico abaixo da correspondente à capacidade de campo; em 1997, da superfície até $3 \mathrm{~m}$ de profundidade, a maioria dos valores esteve acima de $-1 / 3 \mathrm{~atm}$, mantendo-se condiçöes mais favoráveis à drenagem regular através do perfil ; em 1998, os valores de potencial mátrico estiveram abaixo de $-1 / 3$ atm em grande parte do primeiro semestre nos niveis de $1 \mathrm{~m}$ e $1,5 \mathrm{~m}$ e por todo o período de medição desse ano a profundidades inferiores a $2 \mathrm{~m}$. 
Tabela 13: Potencial do solo - tensiômetros - ano de 1996

\begin{tabular}{|c|c|c|c|c|c|c|}
\hline DATA & CHUVA (mm) & $\begin{array}{c}\text { TENS.1 } \\
(\mathrm{HPa})\end{array}$ & $\begin{array}{c}\text { TENS.2 } \\
\text { (HPa) }\end{array}$ & $\begin{array}{l}\text { TENS.3 } \\
\text { (HPa) }\end{array}$ & $\begin{array}{c}\text { TENS. } 4 \\
\text { (HPa) }\end{array}$ & $\begin{array}{c}\text { TENS.7 } \\
(\mathrm{HPa})\end{array}$ \\
\hline $03 / 09 / 96$ & 21,5 & 56364 & -667.47 & 656,3 & 4895 & $-37,08$ \\
\hline $12 / 09 / 96$ & 43,3 & $-56,859$ & $-174,28$ & 6699 & 504,3 & $-35,85$ \\
\hline 19/09/96 & 2,9 & $-93,941$ & $-152,04$ & 666,2 & 5142 & $-61,8$ \\
\hline $26 / 09 / 96$ & 18,8 & $-118,66$ & $-154,51$ & $-676,1$ & $-553,8$ & $-48,21$ \\
\hline $04 / 10 / 96$ & 12 & $-129,79$ & $-46,97$ & 665 & 5587 & $-48,21$ \\
\hline $15 / 10 / 96$ & 36,4 & $-76,636$ & $-93,941$ & -6737 & $-594,5$ & $-65,51$ \\
\hline $22 / 10 / 96$ & 5 & $-205,19$ & 618,03 & 667,5 & 585.9 & $-29,67$ \\
\hline $29 / 10 / 96$ & 94,7 & $-38,318$ & 556,23 & $-667,5$ & 589.6 & $-27,19$ \\
\hline $05 / 11 / 96$ & 10,7 & $-70,455$ & $-98,885$ & $-668,7$ & 592.1 & $-38,32$ \\
\hline 18/11/96 & 145,1 & $-39,554$ & $-14,833$ & -6699 & $-589,6$ & $-70,46$ \\
\hline $26 / 11 / 96$ & 14,2 & $-95,177$ & $-39,554$ & $-652,6$ & $-600,7$ & $-25,96$ \\
\hline $09 / 12 / 96$ & 32,6 & $-75,4$ & $-95,177$ & -6638 & 609.4 & $-118,7$ \\
\hline $17 / 12 / 96$ & 94,1 & $-35,846$ & $-39,554$ & 6811 & 6369 & $-300,4$ \\
\hline $22 / 12 / 96$ & 124,1 & $-48,206$ & $-43,262$ & -5451 & 6242 & $-291,7$ \\
\hline
\end{tabular}

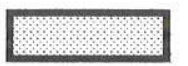

DRENA MUITO POUCO

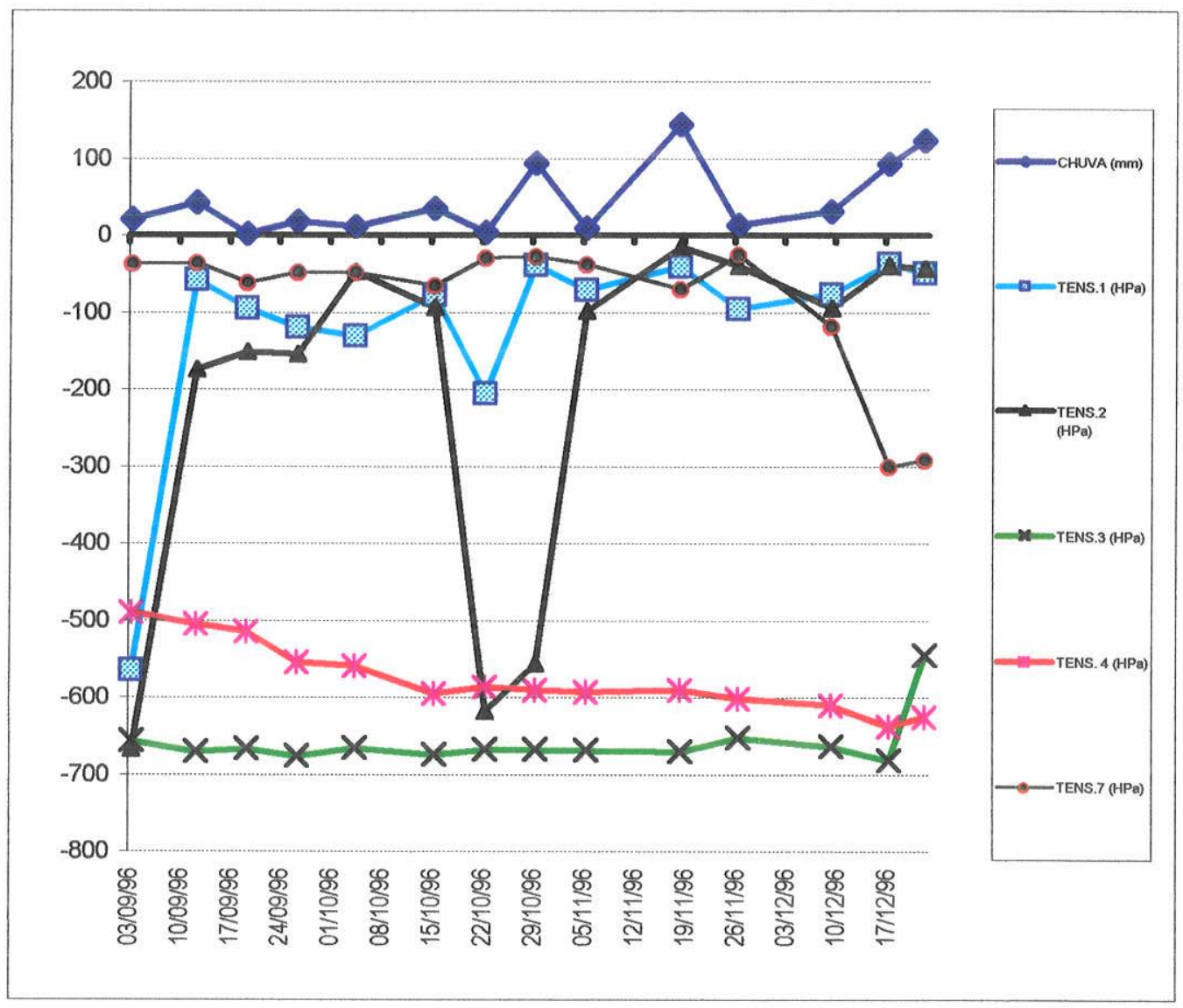

Figura 23: Potencial do solo - tensiômetros - ano de 1996 
Tabela 14: Potencial do solo - tensiômetros - ano de 1997

\begin{tabular}{|c|c|c|c|c|c|c|c|c|}
\hline DATA & CHUVA & TENS.1 & TENS.2 & TENS.3 & TENS.4 & TENS.5 & TENS.6 & TENS.7 \\
& $(\mathrm{mm})$ & $\begin{array}{c}\text { TEm } \\
(\mathrm{HPa})\end{array}$ & $\begin{array}{c}0,50 \mathrm{~m} \\
(\mathrm{HPa})\end{array}$ & $\begin{array}{c}1,00 \mathrm{~m} \\
(\mathrm{HPa})\end{array}$ & $\begin{array}{c}1,50 \mathrm{~m} \\
(\mathrm{HPa})\end{array}$ & $\begin{array}{c}2,00 \mathrm{~m} \\
(\mathrm{HPa})\end{array}$ & $\begin{array}{c}2,50 \mathrm{~m} \\
(\mathrm{HPa})\end{array}$ & $\begin{array}{c}3,00 \mathrm{~m} \\
(\mathrm{HPa})\end{array}$ \\
\hline $22 / 01 / 97$ & 79,80 & $-23,50$ & $-3,71$ & $-6,18$ & $-42,03$ & $-184,17$ & $-244,74$ & $-355,99$ \\
\hline $25 / 02 / 97$ & 55,90 & $-44,50$ & $-13,60$ & $-13,60$ & $-49,44$ & $-101,36$ & $-126,08$ & $-155,74$ \\
\hline $18 / 03 / 97$ & 18,90 & $-63,00$ & $-55,60$ & $-40,79$ & $-86,52$ & $-90,23$ & $-85,29$ & $-81,58$ \\
\hline $09 / 04 / 97$ & 16,40 & $-70,50$ & $-50,70$ & $-77,87$ & $-112,48$ & $-148,33$ & $-138,44$ & $-138,44$ \\
\hline $24 / 04 / 97$ & 18,00 & $-97,20$ & $-66,70$ & $-111,25$ & $-147,09$ & $-177,99$ & $-164,40$ & $-181,70$ \\
\hline $07 / 05 / 97$ & 0,00 & $-275,60$ & $-120,00$ & $-349,80$ & $-223,73$ & $-190,35$ & $-186,65$ & $-195,30$ \\
\hline $14 / 05 / 97$ & 0,00 & $-702,10$ & $-274,00$ & $-676,12$ & $-364,64$ & $-197,77$ & $-185,41$ & $-195,30$ \\
\hline $28 / 05 / 97$ & 73,20 & $-53,20$ & $-126,00$ & $-678,60$ & $-615,56$ & $-238,56$ & $-174,28$ & $-200,24$ \\
\hline $12 / 06 / 97$ & 49,10 & $-17,30$ & $-9,89$ & $-1,24$ & $-661,29$ & $-253,39$ & $-96,41$ & $-226,20$ \\
\hline $27 / 06 / 97$ & 1,80 & $-53,20$ & $-22,20$ & $-17,30$ & $-60,57$ & $-291,71$ & $-213,84$ & $-226,20$ \\
\hline $11 / 07 / 97$ & 0,00 & $-66,70$ & $-66,70$ & $-27,19$ & $-72,93$ & $-89,00$ & $-218,78$ & $-227,44$ \\
\hline $25 / 07 / 97$ & 17,90 & $-71,70$ & $-71,70$ & $-39,55$ & $-87,76$ & $-207,66$ & $-220,02$ & $-217,55$ \\
\hline $08 / 08 / 97$ & 4,00 & $-104,00$ & $-66,70$ & $-50,68$ & $-97,65$ & $-210,13$ & $-217,55$ & $-210,13$ \\
\hline $22 / 08 / 97$ & 0,90 & $-149,60$ & $-91,50$ & $-63,04$ & $-105,07$ & $-213,84$ & $-213,84$ & $-208,89$ \\
\hline $05 / 09 / 97$ & 0,00 & $-341,20$ & $-172,00$ & $-77,87$ & $-111,25$ & $-201,48$ & $-201,48$ & $-213,84$ \\
\hline $19 / 09 / 97$ & 10,20 & $-726,80$ & $-634,00$ & $-123,61$ & $-154,51$ & $-199,01$ & $-197,77$ & $-212,60$ \\
\hline $03 / 10 / 97$ & 65,10 & $-55,60$ & $-649,00$ & $-166,87$ & $-171,81$ & $-197,77$ & $-215,07$ & $-226,20$ \\
\hline $17 / 10 / 97$ & 17,50 & $-98,90$ & $-371,00$ & $-207,66$ & $-206,42$ & $-250,92$ & $-255,86$ & $-269,46$ \\
\hline $30 / 10 / 97$ & 58,40 & $-42,00$ & $-132,00$ & $-271,93$ & $-239,79$ & $-241,02$ & $-236,00$ & $-253,00$ \\
\hline $13 / 11 / 97$ & 24,70 & $-89,00$ & $-177,00$ & $-383,18$ & $-321,37$ & $-309,00$ & $-286,76$ & $-310,24$ \\
\hline $28 / 11 / 97$ & 84,30 & $-19,78$ & $-7,42$ & $-430,13$ & $-338,68$ & $-302,83$ & $-271,93$ & $-351,04$ \\
\hline $13 / 12 / 97$ & 0,80 & $-66,70$ & $-37,08$ & $-228,67$ & $-373,29$ & $-346,09$ & $-323,85$ & $-363,38$ \\
\hline $27 / 12 / 97$ & 5,90 & $-107,54$ & $-79,11$ & $-309,00$ & $-409,11$ & $-337,44$ & $-325,08$ & $-368,35$ \\
\hline
\end{tabular}

349,60 DRENA MUITO POUCO

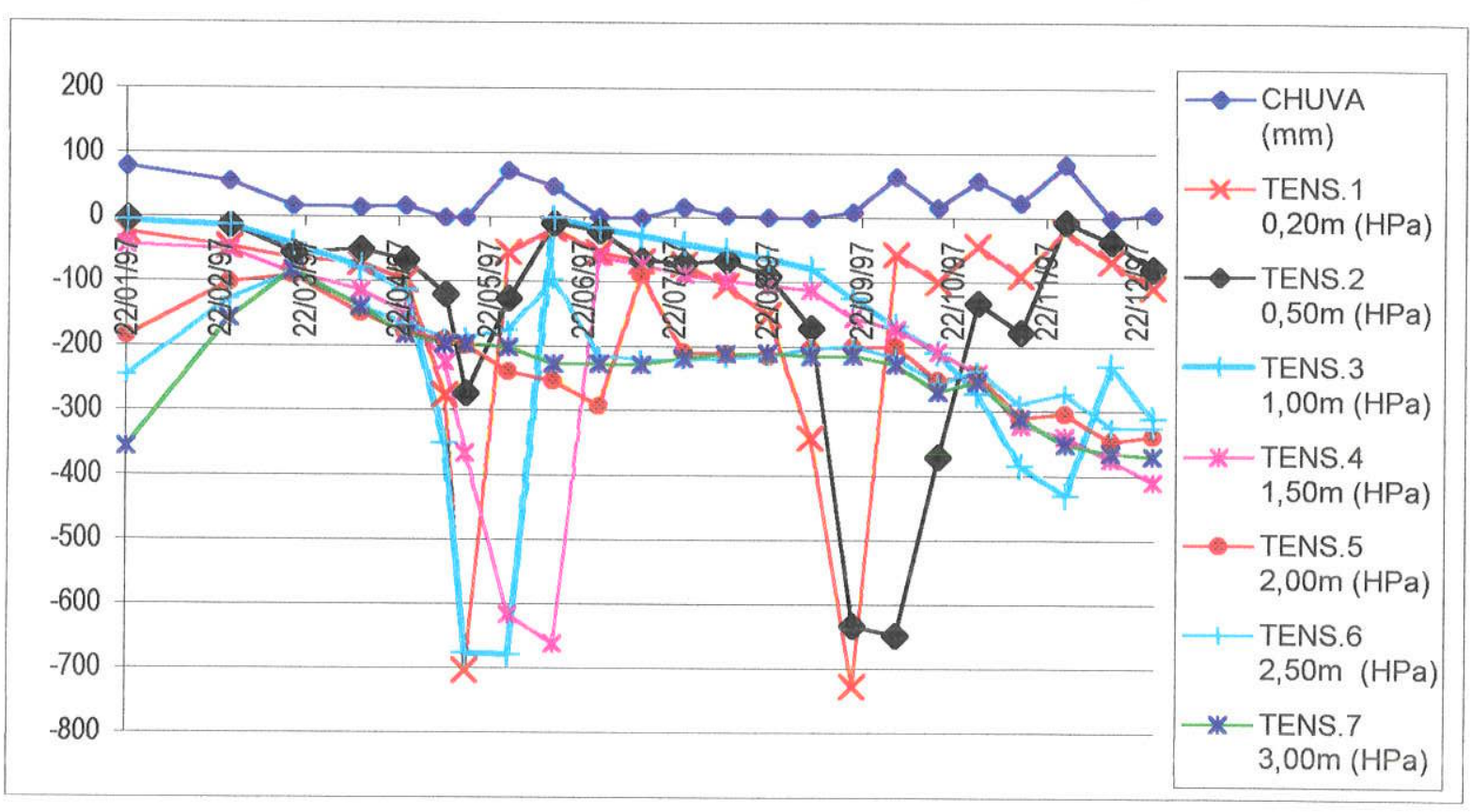

Figura 24: Potencial do solo - tensiômetros - ano de 1997 
Tabela 15: Potencial do solo - Tensiômetros - ano de 1998

\begin{tabular}{|c|c|c|c|c|c|c|c|c|}
\hline DATA & $\begin{array}{l}\text { CHUVA } \\
\text { NA } \\
\text { SEMANA } \\
(\mathrm{mm})\end{array}$ & $\begin{array}{r}\text { TENS.1 } \\
0,20 \mathrm{~m} \\
(\mathrm{HPa})\end{array}$ & $\begin{array}{r}\text { TENS.2 } \\
0,50 \mathrm{~m} \\
(\mathrm{HPa})\end{array}$ & $\begin{array}{r}\text { TENS.3 } \\
1,00 \mathrm{~m} \\
(\mathrm{HPa})\end{array}$ & $\begin{array}{r}\text { TENS.4 } \\
1,50 \mathrm{~m} \\
(\mathrm{HPa})\end{array}$ & $\begin{array}{r}\text { TENS.5 } \\
2,00 \mathrm{~m} \\
(\mathrm{HPa})\end{array}$ & $\begin{array}{r}\text { TENS.6 } \\
2,50 \mathrm{~m} \\
(\mathrm{HPa})\end{array}$ & $\begin{array}{r}\text { TENS.7 } \\
3,00 \mathrm{~m} \\
(\mathrm{HPa})\end{array}$ \\
\hline 03/01/98 & 3,80 & $-180,46$ & $-119,90$ & $-451,16$ & $-447,45$ & $-359,69$ & $-339,92$ & $-385,65$ \\
\hline $10 / 01 / 98$ & 95,20 & $-54,39$ & $-103,83$ & $-546,34$ & $-489,48$ & $-441,27$ & $-354,75$ & $-402,96$ \\
\hline $17 / 01 / 98$ & 53,60 & $-39,55$ & $-101,36$ & $-588,36$ & $-556,23$ & $-375,76$ & $-344,86$ & $-388,12$ \\
\hline $24 / 01 / 98$ & 1,20 & $-86,52$ & $-122,37$ & $-610,61$ & $-521,62$ & $-380,71$ & $-347,33$ & $-390,59$ \\
\hline $31 / 01 / 98$ & 6,80 & $-145,86$ & $-179,23$ & $-681,07$ & $-552,52$ & $-399,25$ & $-362,17$ & $-401,72$ \\
\hline $07 / 02 / 98$ & 15,00 & $-401,72$ & $-306,54$ & $-625,45$ & $-563,64$ & $-401,72$ & $-358,46$ & $-399,25$ \\
\hline $14 / 02 / 98$ & 5,00 & $-697,14$ & $-626,68$ & $-653,88$ & $-601,96$ & $-441,27$ & $-393,07$ & $-426,44$ \\
\hline $21 / 02 / 98$ & 9,90 & $-734,22$ & $-684,78$ & $-661,29$ & $-593,31$ & $-433,86$ & $-384,41$ & $-414,08$ \\
\hline $28 / 02 / 98$ & 47,00 & $-428,91$ & $-698,37$ & $-661,29$ & $-595,78$ & $-448,69$ & $-393,07$ & $-417,79$ \\
\hline $07 / 03 / 98$ & 89,60 & $-32,14$ & $-67,98$ & $-640,28$ & $-604,43$ & $-463,52$ & $-368,35$ & $-446,22$ \\
\hline $14 / 03 / 98$ & 38,00 & $-37,08$ & $-50,68$ & $-395,54$ & $-608,14$ & $-500,60$ & $-417,79$ & $-467,23$ \\
\hline $21 / 03 / 98$ & 54,80 & $-27,19$ & $-33,37$ & $-545,10$ & $-625,45$ & $-510,49$ & $-435,09$ & $-464,76$ \\
\hline $28 / 03 / 98$ & 57,00 & $-32,14$ & $-21,01$ & $-634,10$ & $-624,21$ & $-520,38$ & $-443,75$ & $-465,99$ \\
\hline $04 / 04 / 98$ & 145,40 & $-39,55$ & $-16,07$ & $-23,49$ & $-626,68$ & $-535,21$ & $-462,29$ & $-470,94$ \\
\hline $11 / 04 / 98$ & 27,30 & $-43,26$ & $-17,30$ & $-14,83$ & $-626,68$ & $-541,39$ & $-266,99$ & $-435,09$ \\
\hline $18 / 04 / 98$ & 39,20 & $-28,43$ & $-11,12$ & $-25,96$ & $-593,31$ & $-542,63$ & $-389,36$ & $-470,94$ \\
\hline $25 / 04 / 98$ & 16,10 & $-50,68$ & $-24,72$ & $-28,43$ & $-349,80$ & $-529,03$ & $-419,02$ & $-459,81$ \\
\hline $02 / 05 / 98$ & 28,20 & $-40,79$ & $-21,01$ & $-33,37$ & $-260,81$ & $-548,81$ & $-438,80$ & $-474,65$ \\
\hline $08 / 05 / 98$ & 40,50 & $-40,79$ & $-14,83$ & $-12,36$ & $-180,46$ & $-557,46$ & $-449,93$ & $-482,06$ \\
\hline $14 / 05 / 98$ & 10,40 & $-58,09$ & $-24,72$ & $-18,54$ & $-129,79$ & $-548,81$ & $-441,27$ & $-469,70$ \\
\hline $21 / 05 / 98$ & 9,10 & $-56,86$ & $-28,43$ & $-27,19$ & $-112,48$ & $-559,94$ & $-454,87$ & $-477,12$ \\
\hline $28 / 05 / 98$ & 3,60 & $-71,69$ & $-40,79$ & $-34,61$ & $-110,01$ & $-558,70$ & $-461,05$ & $-474,65$ \\
\hline $04 / 06 / 98$ & 22,80 & $-64,28$ & $-43,26$ & $-39,55$ & $-111,25$ & $-562,41$ & $-462,29$ & $-487,01$ \\
\hline $11 / 06 / 98$ & 0,00 & $-85,29$ & $-54,39$ & $-50,68$ & $-121,13$ & $-554,99$ & $-454,87$ & $-467,23$ \\
\hline $17 / 06 / 98$ & 0,00 & $-97,65$ & $-60,57$ & $-55,62$ & $-127,31$ & $-574,77$ & $-399,25$ & $-470,94$ \\
\hline
\end{tabular}

$-350,00$

DRENA MUITO POUCO

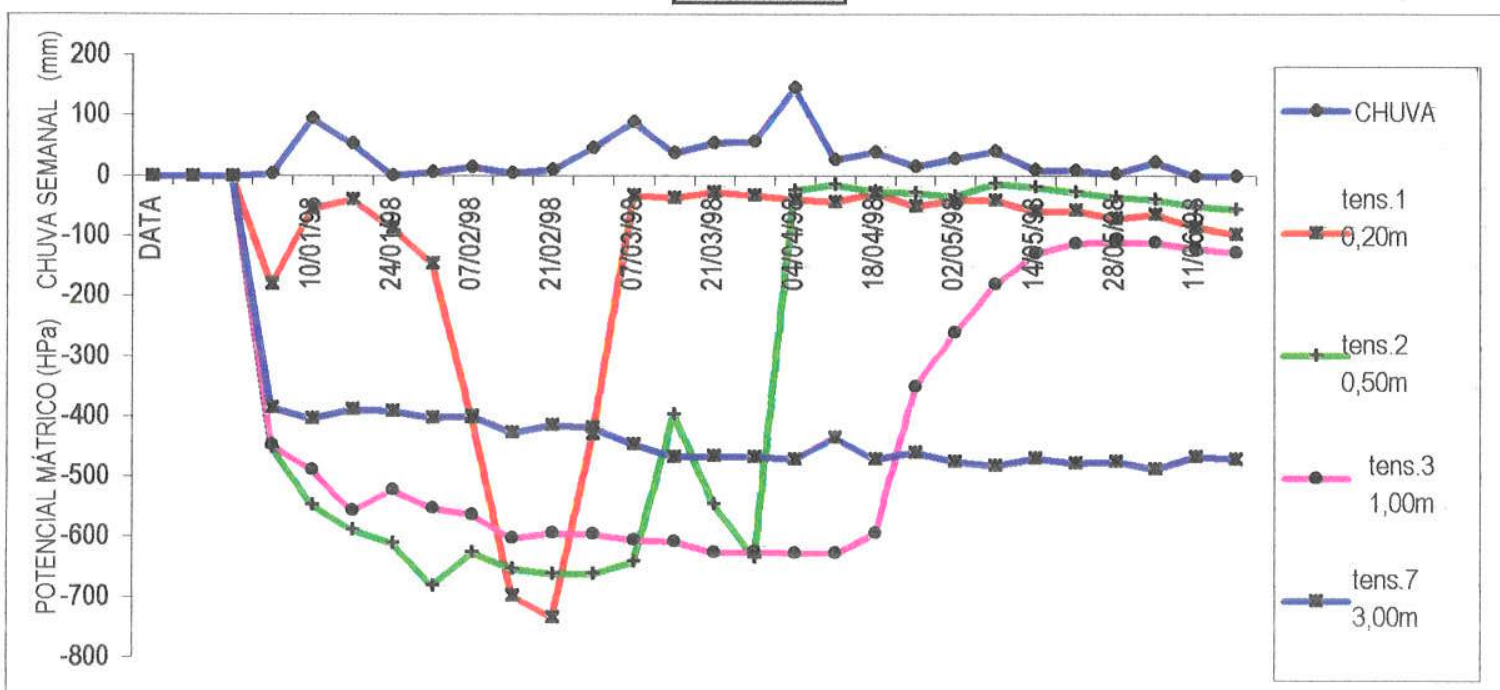

Figura 25 : Potencial do solo - tensiômetros - ano de 1998 
Deduz-se que, apesar da pluviosidade alta, a taxa de drenagem abaixo de $1,00 \mathrm{~m}$ foi reduzida na maior parte do período considerado nos 3 anos. Esta profundidade corresponde à localização do horizonte $B$ textural, considerado como o de menor condutividade hidráulica de todos aqueles identificados no perfil.

A análise do comportamento da potencial mátrico contribui para o entendimento dos mecanismos de distribuição de água no solo. Para uma análise da variação diária do potencial mátrico e do armazenamento de água a diferentes profundidades, foram selecionados os resultados obtidos com o tensiômetros nos meses de junho e de outubro de 1997. Valores de umidade, estimados a partir da curva de retenção de água no solo, foram relacionados aos registros de precipitação diária (Tabelas $16 \mathrm{e}$ 17 ).

O mês de junho de 1997, pelos cálculos de balanço hídrico climatológico, é considerado como de deficência hídrica. $O$ solo, no entanto, apresenta umidade relativamente elevada, principalmente na zona compreendida entre a superfície e a profundidade de 0,5 m. A cada evento de precipitação prolongada por mais de um dia, é observado um aumento progressivo de umidade, que pode indicar avanço da frente de molhamento,. Este aumento é menos pronunciado à profundidade de 1,50 e pouco presente à profundidade de $2 \mathrm{~m}$.

O mês de outubro, conforme os cálculos de balanço hídrico climatológico, é considerado como de reposição de água no solo. No entanto, pelos valores estimados de umidade, em comparaçăo com eventos de precipitação nesse mês, não é reconhecido nenhum padrão de redistribuição da água no solo. 
Tabela 16 : Variaçăo da umidade do solo na estação piloto - junho de 1997

\begin{tabular}{|c|c|c|c|c|c|c|}
\hline DATA & $\begin{array}{c}\text { CHUVA } \\
\text { DIARIA } \\
(\mathrm{mm})\end{array}$ & $\begin{array}{c}\text { UMIDADE } \\
\theta(\%)\end{array}$ & $\begin{array}{c}\text { UMIDADE } \\
\theta(\%) \\
0,50 \mathrm{~m}\end{array}$ & $\begin{array}{c}\text { UMIDADE } \\
\theta(\%) \\
1,00 \mathrm{~m}\end{array}$ & $\begin{array}{c}\text { UMIDADE } \\
\theta(\%) \\
1,50 \mathrm{~m}\end{array}$ & $\begin{array}{c}\text { UMIDADE } \\
\theta(\%) \\
2,00 \mathrm{~m}\end{array}$ \\
\hline $02 / 06 / 97$ & - & 27,5 & 26,0 & 20,4 & 20,7 & 20,5 \\
\hline $03 / 6 / 97$ & 15,8 & 28,9 & 22,0 & 20,7 & 20,7 & 20,7 \\
\hline $04 / 6 / 97$ & 47,8 & 38,5 & 26,1 & 20,6 & 20,7 & 20,6 \\
\hline $05 / 06 / 97$ & 58,2 & 39,0 & $36,1,7$ & 20,5 & 20,7 & 20,5 \\
\hline $06 / 06 / 97$ & 0,5 & 32,0 & 39,5 & 21,5 & 20,7 & 20,4 \\
\hline $07 / 06 / 97$ & - & 31,5 & 30,5 & 28,5 & 20,7 & 20,0 \\
\hline $08 / 06 / 97$ & - & 30,5 & 36,0 & 31,0 & 20,7 & 21,9 \\
\hline $09 / 06 / 97$ & - & 30,0 & 36,1 & 32,4 & 20,6 & 28,5 \\
\hline $10 / 06 / 97$ & - & 30,0 & 36,1 & 32,7 & 20,6 & 33,0 \\
\hline $11 / 06 / 97$ & 14,1 & 29,5 & 36,0 & 38,8 & 20,7 & 29,0 \\
\hline $12 / 06 / 97$ & 35,0 & 37,0 & 39,7 & 42,5 & 20,6 & 22,3 \\
\hline $13 / 06 / 97$ & - & 38,5 & 40,7 & 42,5 & 20,7 & 22,0 \\
\hline $14 / 06 / 97$ & 45,1 & 31,7 & 40,7 & 42,5 & 20,9 & 20,6 \\
\hline $15 / 06 / 97$ & 2,4 & 30,2 & 39,7 & 41,0 & 24,0 & 20,5 \\
\hline $16 / 06 / 97$ & - & 31,7 & 39,6 & 40,8 & 28,0 & 20,7 \\
\hline $17 / 06 / 97$ & 5,9 & 31,0 & 39,6 & 40,8 & 28,3 & 2,9 \\
\hline $18 / 06 / 97$ & 1,1 & 30,2 & 39,7 & 40,0 & 28,3 & 21,4 \\
\hline $19 / 06 / 97$ & - & 29,3 & 40,7 & 40,8 & 28,5 & 24,0 \\
\hline $2006 / 97$ & 1,8 & 29,5 & 39,4 & 40,0 & 30,0 & 20,4 \\
\hline $21 / 06 / 97$ & - & 29,0 & 36,2 & 38,7 & 30,0 & 20,0 \\
\hline $22 / 06 / 97$ & - & 28,8 & 36,0 & 38,6 & 30,0 & 29,5 \\
\hline $23 / 06 / 97$ & - & 28,8 & 36,0 & 38,6 & 31,0 & 19,7 \\
\hline $24 / 06 / 97$ & - & 28,5 & 36,1 & 37,6 & 31,0 & 20,3 \\
\hline $25 / 06 / 97$ & - & 28,0 & 36,1 & 37,0 & 33,0 & 20,4 \\
\hline
\end{tabular}


Tabela 17 : Variação da umidade no solo da estação piloto - outubro de 1997

\begin{tabular}{|c|c|c|c|c|c|c|}
\hline DATA & $\begin{array}{c}\text { CHUVA } \\
\text { DIARIA } \\
(\mathrm{mm})\end{array}$ & $\begin{array}{c}\text { UMIDADE } \\
\theta(\%) \\
0,20 \mathrm{~m} \\
\end{array}$ & $\begin{array}{c}\text { UMIDADE } \\
\theta(\%) \\
0,50 \mathrm{~m} \\
\end{array}$ & $\begin{array}{c}\text { UMIDADE } \\
\theta(\%) \\
1,00 \mathrm{~m} \\
\end{array}$ & $\begin{array}{c}\text { UMIDADE } \\
\theta(\%) \\
1,50 \mathrm{~m} \\
\end{array}$ & $\begin{array}{c}\text { UMIDADE } \\
\theta(\%) \\
2,00 \mathrm{~m} \\
\end{array}$ \\
\hline $01 / 10 / 97$ & 53,7 & 250 & 160 & 23,5 & 23,1 & 18,5 \\
\hline $02 / 10 / 97$ & - & 23,0 & 175 & 23,4 & 232 & 18,7 \\
\hline $03 / 10 / 97$ & - & 22,5 & 17,0 & 23,3 & 233 & 19,5 \\
\hline $04 / 10 / 97$ & - & 22,0 & 173 & 23,4 & 23,3 & 18,0 \\
\hline $05 / 10 / 97$ & - & 20,0 & 17,5 & 23,3 & 23,0 & 18,4 \\
\hline $06 / 10 / 97$ & - & 19,0 & 17,5 & 23,3 & 22,9 & 17,9 \\
\hline $07 / 10 / 97$ & - & 19,0 & 18,0 & 23,2 & 22,3 & 18,6 \\
\hline $08 / 10 / 97$ & - & 20,5 & 18,5 & 23,1 & 23,4 & 193 \\
\hline $09 / 10 / 97$ & - & 20.5 & 18,7 & 23,3 & 23,0 & 19,5 \\
\hline $10 / 10 / 97$ & - & 19,6 & 18,6 & 23,1 & 22,8 & 193 \\
\hline $11 / 10 / 97$ & 0,4 & 19,5 & 17,5 & 23,1 & 23,0 & 18,6 \\
\hline $12 / 10 / 97$ & - & 19,3 & 17,6 & 23,0 & 22,7 & 18,5 \\
\hline $13 / 10 / 97$ & - & 19,2 & 17,5 & 22,5 & 22,7 & 18,4 \\
\hline $14 / 10 / 97$ & - & 17,5 & 17,1 & 22,4 & 22,7 & 18,6 \\
\hline $15 / 10 / 97$ & - & 16,2 & 17,0 & 22,0 & 22,7 & 18,8 \\
\hline $16 / 10 / 97$ & 17,1 & 16,7 & 17,6 & 22,0 & 21,8 & 17,5 \\
\hline $17 / 10 / 97$ & - & 19,5 & 17,6 & 23,0 & 21,9 & 18,6 \\
\hline $18 / 10197$ & - & 19.5 & 17,5 & 21,9 & 21,7 & 18,3 \\
\hline $19 / 10 / 97$ & 0,1 & 19,0 & 17,4 & 21,8 & 21,7 & 17,9 \\
\hline $20 / 10 / 97$ & 20,6 & 17,5 & 17,4 & 21,8 & 21,8 & 17,5 \\
\hline $21 / 10 / 97$ & - & 24,6 & 17,4 & 21,7 & 21,8 & 18,3 \\
\hline $22 / 10 / 97$ & - & 21,2 & 17,4 & 21,7 & 21,8 & 17,6 \\
\hline $23 / 10 / 97$ & + & 21,2 & 17,5 & 21,6 & 21,7 & 18,7 \\
\hline $24 / 10 / 97$ & - & 21,0 & 17,4 & 21,6 & 21,7 & 18,5 \\
\hline $25 / 10 / 97$ & 6,5 & 21,0 & 17,4 & 21,6 & 21,6 & 17,6 \\
\hline $26 / 10 / 97$ & 38,7 & 29,8 & 17,6 & 21,5 & 21,6 & 17,9 \\
\hline $27 / 10 / 97$ & - & 28,0 & $18 ; 6$ & 21,5 & 21,5 & 17,3 \\
\hline $28 / 10 / 97$ & - & 25,5 & 18,7 & 21,5 & 21,6 & 18,5 \\
\hline $29 / 10 / 97$ & - & 24,0 & 18,8 & 21,4 & 21,7 & 18,7 \\
\hline $30 / 10 / 97$ & 13,2 & 27,5 & 18,9 & 21,3 & 21,6 & 18,7 \\
\hline
\end{tabular}


B - Resultados dos blocos de gesso

Os resultados apresentados na Tabela 18 discordam muito das padrões de valores esperados para as variações climáticas observadas, assim como para esta classe de um solo, podzólico vermetho-amarelo, identificado na área em estudo, com respeito ao comportamento do potencial mátrico, o qual reflete o desenvolvimento dos processos de infiltração e de redistribuição. Por cautela, estes resultados não devem ser considerados.

Tabela 18: Potencial do solo - blocos de gesso

\begin{tabular}{|c|c|c|c|c|c|c|c|}
\hline \multirow{2}{*}{ DATA } & \multirow{3}{*}{$\begin{array}{c}\text { CHUVA } \\
(\mathrm{mm})\end{array}$} & \multicolumn{2}{|c|}{ PROFUNDIDADE DE INSTALACAO } \\
\cline { 3 - 8 } & $0,20 \mathrm{~m}$ & $0,50 \mathrm{~m}$ & $1,00 \mathrm{~m}$ & $1,50 \mathrm{~m}$ & $3,00 \mathrm{~m}$ & $4,70 \mathrm{~m}$ \\
\hline $27 / 05 / 97$ & 73,20 & -200 & -1550 & -320 & -1070 & -300 & -600 \\
\hline $06 / 06 / 97$ & 122,30 & -230 & -1700 & -330 & -1270 & -320 & -630 \\
\hline $11 / 06 / 97$ & 35,00 & -200 & -250 & -250 & -1750 & -350 & -700 \\
\hline $20 / 06 / 97$ & 91,30 & -200 & -230 & -250 & -2000 & -350 & -715 \\
\hline $04 / 07 / 97$ & 11,00 & -200 & -200 & -230 & -440 & -380 & -740 \\
\hline $22 / 07 / 97$ & 17,90 & -200 & -200 & -230 & -400 & -380 & -800 \\
\hline $15 / 08 / 97$ & 4,00 & -200 & -200 & -230 & -420 & -380 & -800 \\
\hline $29 / 08 / 97$ & 13,10 & -200 & -200 & -250 & -420 & -380 & -800 \\
\hline $12 / 09 / 97$ & 0,00 & -750 & -200 & -250 & -420 & -400 & -840 \\
\hline $25 / 09 / 97$ & 34,70 & -800 & -230 & -230 & -440 & -420 & -880 \\
\hline $03 / 10 / 97$ & 73,20 & -530 & -230 & -250 & -460 & -420 & -900 \\
\hline $17 / 10 / 97$ & 17,50 & -300 & -350 & -250 & -450 & -510 & -1020 \\
\hline $30 / 10 / 97$ & 79,10 & -230 & -900 & -300 & -510 & -680 & -1060 \\
\hline $14 / 11 / 97$ & 49,70 & -230 & -2200 & -400 & -600 & -1050 & -1500 \\
\hline $21 / 11 / 97$ & 85,90 & -200 & -1700 & -480 & -650 & -1100 & -1550 \\
\hline $05 / 12 / 97$ & 100,30 & -200 & -230 & -520 & -700 & -1400 & -1900 \\
\hline $18 / 12 / 97$ & 25,60 & -200 & -200 & -480 & -720 & -1600 & -2600 \\
\hline $06 / 01 / 98$ & 83,6 & -200 & -250 & -590 & -950 & -3500 & -7000 \\
\hline $13 / 01 / 98$ & 17,8 & -200 & -250 & -570 & -1000 & -4000 & -9000 \\
\hline $23 / 01 / 98$ & 48,6 & -200 & -350 & -690 & -1180 & -5500 & -12000 \\
\hline
\end{tabular}

ABAIXO DA CAPACIDADE DE CAMPO 
O emprego destes blocos na pesquisa revelou algumas de suas limitações como recurso de medida do potencial mátrico, tais como: a restrição no intervalo de valores do ábaco com referência às sucçōes de menor intensidade, começando em $-0,1$ Bar ou -100 HPa na escala de potencial mátrico; graduação pouco precisa desta mesma escala, dificultando a detecção de variações iguais ou menores que $20 \mathrm{HPa}$; raio de medição muito limitado no solo, sujeitando a medida à influência de biocavidades ou de concentração de umidade em torno de raízes fasciculadas; sensibilidade à influência da presença de sais dissolvidos na água.

\subsubsection{Comportamento do Nível Freático}

Na Tabela 19 estão representadas as variações de nível freático, expressas em valores de profundidade e de cotas e referentes aos poços de monitoramento e a 2 cacimbas. Com base no valor médio das medidas assim obtidas e em dados previamente existentes e relativos a cacimbas e escavaçőes de fundações de edificações nas redondezas do Campus da UNESP (GODOY, 1997), construiu-se um mapa potenciométrico, (Figura 30). A combinação destes dados revela as seguintes particularidades do topo da zona saturada:

- a orientação das linhas equipotenciais reforça a concepção anterior sobre as orientações de fluxo de acordo com a orientação do declive da encosta;

- a curva de 426 m apresenta uma variação brusca, devida a uma discrepância entre valores de medidas referentes aos poços PMO3 e PM04, localizados no mesmo setor da encosta, indicando a influência de estrato compacto de lamito;

- não foi possivel traçar curvas com referência à área de altitude inferior a 420 $\mathrm{m}$, onde estão localizados os poços PM06 e PM07 e 2 cacimbas, por impossibilidade de interpolação dos valores de nível determinados para estes locais com os valores referentes aos poços instalados a montante, deste modo sendo caracterizada uma separação de aqǘferos. 
Tabela 19: Variação do nivel do aqüifero livre

\begin{tabular}{|c|c|c|c|c|c|c|c|c|c|c|}
\hline LOCAL & & PM01 & $\mathrm{PMO2}$ & PMO3 & PMO4 & PM05 & $\mathrm{C} 1$ & $\mathrm{C} 2$ & PMO6 & PMO7 \\
\hline $\begin{array}{c}\text { COTA } \\
\text { DE BOCA }\end{array}$ & (m) & 439,27 & 438,62 & 436,58 & 435,8 & 428,4 & 434,4 & 436,5 & 418,24 & 412,21 \\
\hline DATA & $\begin{array}{l}\text { CHUVA } \\
\text { (mm) }\end{array}$ & $\begin{array}{l}\text { NIVEL } \\
(\mathrm{m})\end{array}$ & $\begin{array}{l}\text { NIVEL } \\
(\mathrm{m})\end{array}$ & $\begin{array}{c}\text { NIVEL } \\
(\mathrm{m})\end{array}$ & $\begin{array}{c}\text { NIVEL } \\
(\mathrm{m})\end{array}$ & $\begin{array}{l}\text { NIVEL } \\
(\mathrm{m})\end{array}$ & $\begin{array}{c}\text { NIVEL } \\
(\mathrm{m})\end{array}$ & $\begin{array}{r}\text { NIVEL } \\
(\mathrm{m})\end{array}$ & $\begin{array}{l}\text { NIVEL } \\
(\mathrm{m})\end{array}$ & $\begin{array}{c}\text { NIVEL } \\
(\mathrm{m})\end{array}$ \\
\hline $11 / 05 / 96$ & 97,2 & 426,07 & 425,74 & & & & 424,3 & 424,55 & & \\
\hline $04 / 06 / 96$ & 58,2 & 426,19 & 426 & & & & 424,3 & 424,55 & & \\
\hline $13 / 08 / 96$ & 24,5 & 426,63 & 426,03 & 425,16 & 425,79 & 424,04 & 424,26 & 424,67 & & \\
\hline $23 / 08 / 96$ & 1,2 & 426,59 & 425,99 & 425,12 & 425,76 & 423,99 & 424,22 & 424,64 & & \\
\hline $12109 / 96$ & 67,3 & 426,67 & 426 & 425,08 & 425,73 & 423,94 & 424,19 & 424,6 & & \\
\hline $18 / 09 / 96$ & 2,9 & 426,18 & 425,98 & 425,03 & 425,68 & 423,92 & 424,21 & 424,55 & & \\
\hline $22 / 10 / 96$ & 72,2 & 426,11 & 425,93 & 424,98 & 425,64 & 423,89 & 424,24 & 424,64 & & \\
\hline $15 / 12 / 96$ & 368,9 & 426,15 & 425,95 & 425,06 & 425,71 & 423,92 & 424,42 & 424,07 & & \\
\hline $26 / 02 / 97$ & 673 & 426,31 & 426,12 & 425,34 & 426 & 425,05 & 424,55 & 424,8 & & \\
\hline $30 / 03 / 97$ & 41,1 & 426,52 & 426,26 & 425,65 & 426,28 & 424,71 & 424,92 & 424,99 & & \\
\hline $05 / 05197$ & 92 & 426,71 & 426,48 & 425,73 & 426,32 & 424,53 & 424,94 & 424,97 & & \\
\hline $27 / 05 / 97$ & 78,6 & 426,7 & 426,55 & 425,74 & 426,29 & 424,46 & 424,74 & 424,98 & & \\
\hline $11 / 06 / 97$ & 124,2 & 426,71 & 426,56 & 425,71 & 426,31 & 424,9 & 425,14 & 424,98 & & \\
\hline $02 / 07 / 97$ & 116,4 & 426,76 & 426,94 & 425,79 & 426,39 & 424,92 & 425,26 & 425 & & \\
\hline $23107 / 97$ & 17,9 & 426,82 & 426,67 & 425,86 & 426,46 & 424,72 & 425,29 & 425,03 & & \\
\hline $27 / 08 / 97$ & 16,2 & 426,86 & 426,69 & 425,86 & 426,44 & 424,46 & 425,32 & 425,08 & & \\
\hline $17 / 09 / 97$ & 10,2 & 426,86 & 426,66 & 425,77 & 426,35 & 424,34 & 425,15 & 425,1 & & \\
\hline $10 / 10 / 97$ & 107,9 & 426,82 & 426,63 & 425,71 & 426,27 & 424,27 & 424,96 & 425,07 & & \\
\hline $30 / 10 / 97$ & 83,4 & 426,78 & 426,56 & 425,65 & 426,19 & 424,28 & 424,77 & 425,02 & & \\
\hline $26 / 11 / 97$ & 204,6 & 427,04 & 426,5 & 425,58 & 426,16 & 424,46 & 424,75 & 425,01 & & \\
\hline $19 / 12 / 97$ & 70,1 & 426,68 & 426,48 & 425,58 & 426,16 & 424,47 & 424,73 & 425 & & \\
\hline $18 / 01 / 98$ & 158,5 & 426,67 & 426,47 & 425,52 & 426,16 & 424,31 & 424,59 & 424,93 & 412,66 & 405,83 \\
\hline $08 / 02 / 98$ & 25 & 426,6 & 426,4 & 425,46 & 426,06 & 424,2 & 424,46 & 424,9 & 412,15 & 405,52 \\
\hline 02103198 & 142,6 & 426,54 & 426,36 & 425,41 & 426,05 & 424,23 & 424,37 & 424,86 & 412,27 & 405,32 \\
\hline 25103198 & 127,4 & 426,51 & 426,33 & 425,39 & 426,02 & 424,31 & 424,33 & 424,8 & 412,72 & 405,61 \\
\hline $22 / 04 / 98$ & 255 & 426,76 & 426,54 & 425,5 & 426,09 & 424,69 & 424,6 & 424,81 & 413,02 & 407,1 \\
\hline 27105198 & 107,9 & 426,66 & 426,51 & 425,67 & 426,24 & 424,6 & 424,71 & 424,88 & 412,43 & 406,35 \\
\hline $24 / 06 / 98$ & 28 & 426,72 & 426,55 & 425,7 & 426,28 & 424,43 & 424,6 & 424,87 & 412,17 & 405,77 \\
\hline $27 / 07 / 98$ & 7,2 & 426,7 & 426,52 & 425,62 & 426,21 & 424,28 & 424,45 & 424,86 & 411,86 & 405,34 \\
\hline $17 / 08 / 98$ & 128,1 & 426,7 & 426,49 & 425,59 & 426,17 & 424,38 & 424,37 & 424,87 & 412,3 & 405,44 \\
\hline
\end{tabular}


Tabela 20: Variação da profundidade do topo do aqüifero livre

\begin{tabular}{|c|c|c|c|c|c|c|c|c|}
\hline DATA & CHUVA & PM01 & PM02 & PM03 & PM04 & PM05 & C1 & C2 \\
\hline & $(\mathrm{mm})$ & $(\mathrm{cm})$ & $(\mathrm{cm})$ & $(\mathrm{cm})$ & $(\mathrm{cm})$ & $(\mathrm{cm})$ & $(\mathrm{cm})$ & $(\mathrm{cm})$ \\
\hline $11 / 05 / 96$ & 97,2 & -1320 & -1288 & & & & -1010 & -1195 \\
\hline $04 / 06 / 96$ & 58,2 & -1308 & -1262 & & & & -1010 & -1195 \\
\hline $13 / 08 / 96$ & 24,5 & -1264 & -1259 & -1142 & -1001 & -436 & -1014 & -1183 \\
\hline $23 / 08 / 96$ & 1,2 & -1268 & -1263 & -1146 & -1004 & -441 & -1018 & -1186 \\
\hline $12 / 09 / 96$ & 67,3 & -1260 & -1262 & -1150 & -1007 & -446 & -1021 & -1190 \\
\hline $18 / 09 / 96$ & 2,9 & -1309 & -1264 & -1155 & -1012 & -448 & -1019 & -1195 \\
\hline $22 / 10 / 96$ & 72,2 & -1316 & -1269 & -1160 & -1016 & -451 & -1016 & -1186 \\
\hline $15 / 12 / 96$ & 368,9 & -1312 & -1267 & -1152 & -1009 & -448 & -998 & -1243 \\
\hline
\end{tabular}

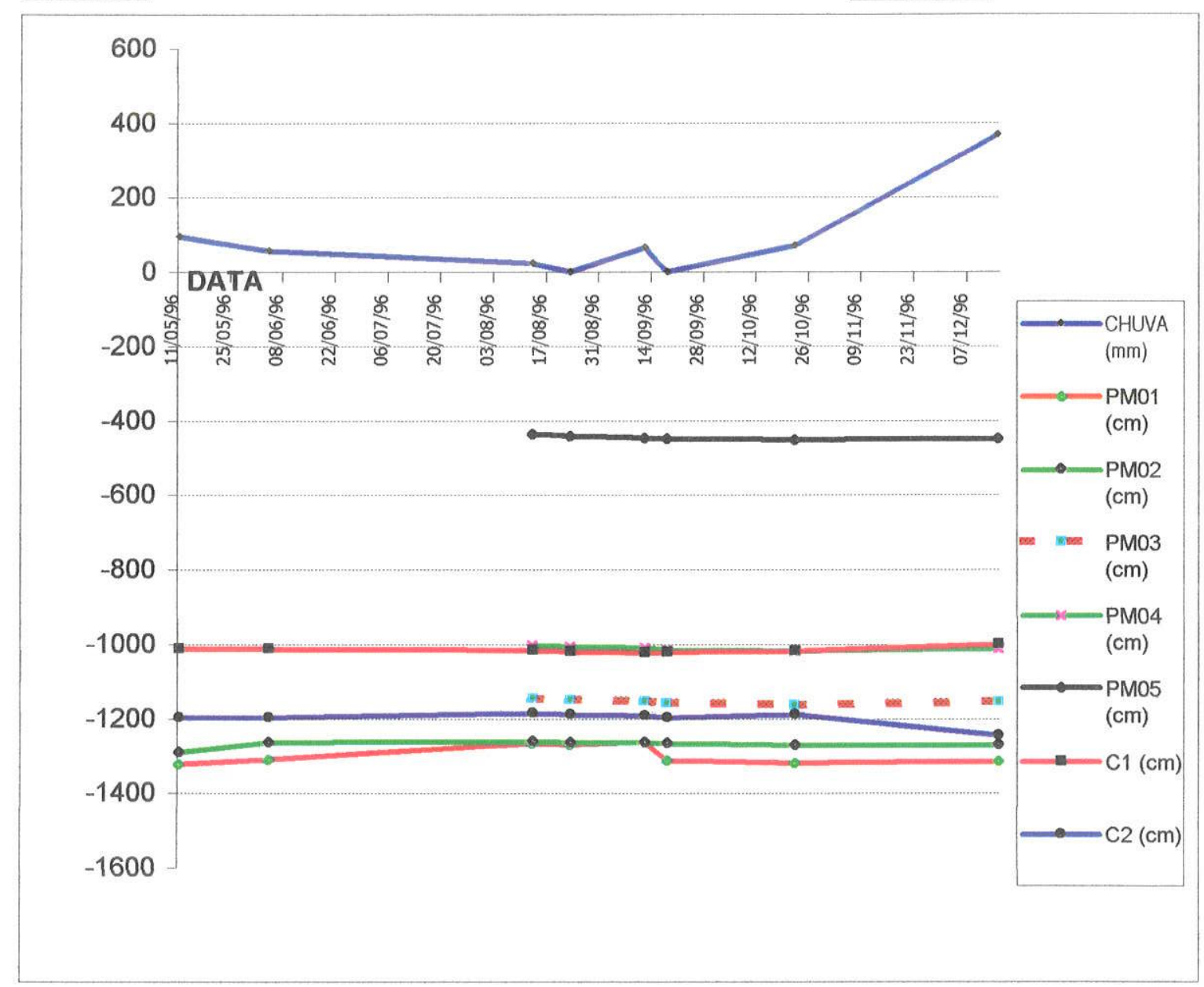

Figura 26: Variação da profundidade do topo do aqüifero livre 
Tabela 21: Variação da profundidade do topo do aqüifero livre - ano de 1997

\begin{tabular}{|c|c|c|c|c|c|c|c|c|}
\hline DATA & CHUVA & \multicolumn{7}{|c|}{ PROFUNDIDADE } \\
\cline { 3 - 9 } & $(\mathrm{cm})$ & PM01 & PM02 & PM03 & PM04 & PM05 & C1 & C2 \\
\hline $26 / 02 / 97$ & $\mathbf{6 7 3}$ & -1296 & -1250 & -1124 & -980 & -335 & -985 & -1170 \\
\hline $30 / 03 / 97$ & $\mathbf{4 1 , 1}$ & -1275 & -1236 & -1093 & -952 & -369 & -948 & -1151 \\
\hline $05 / 05 / 97$ & $\mathbf{9 2}$ & -1256 & -1214 & -1085 & -948 & -387 & -946 & -1153 \\
\hline $27 / 05 / 97$ & $\mathbf{7 8 , 6}$ & -1257 & -1207 & -1084 & -951 & -394 & -966 & -1152 \\
\hline $11 / 06 / 97$ & $\mathbf{1 2 4 , 2}$ & -1256 & -1206 & -1087 & -949 & -350 & -926 & -1152 \\
\hline $02 / 07 / 97$ & $\mathbf{1 1 6 , 4}$ & -1251 & -1168 & -1079 & -941 & -348 & -914 & -1150 \\
\hline $23 / 07 / 97$ & $\mathbf{1 7 , 9}$ & -1245 & -1195 & $-\mathbf{1 0 7 2}$ & $-\mathbf{9 3 4}$ & -368 & -911 & -1147 \\
\hline $27 / 08 / 97$ & $\mathbf{1 6 , 2}$ & -1241 & -1193 & -1072 & -936 & -394 & -908 & -1142 \\
\hline $17 / 09 / 97$ & $\mathbf{1 0 , 2}$ & -1241 & -1196 & -1081 & -945 & -406 & -925 & -1140 \\
\hline $10 / 10 / 97$ & $\mathbf{1 0 7 , 9}$ & -1245 & -1199 & -1087 & -953 & -413 & -944 & -1143 \\
\hline $30 / 10 / 97$ & $\mathbf{8 3 , 4}$ & -1249 & -1206 & -1093 & -961 & -412 & -963 & -1148 \\
\hline $26 / 11 / 97$ & $\mathbf{2 0 4 , 6}$ & -1223 & -1212 & -1100 & -964 & -394 & -965 & -1149 \\
\hline $19 / 12 / 97$ & $\mathbf{7 0 , 1}$ & -1259 & -1214 & -1100 & -964 & -393 & -967 & -1150 \\
\hline
\end{tabular}

-348 PICO

ELEVAÇÃO

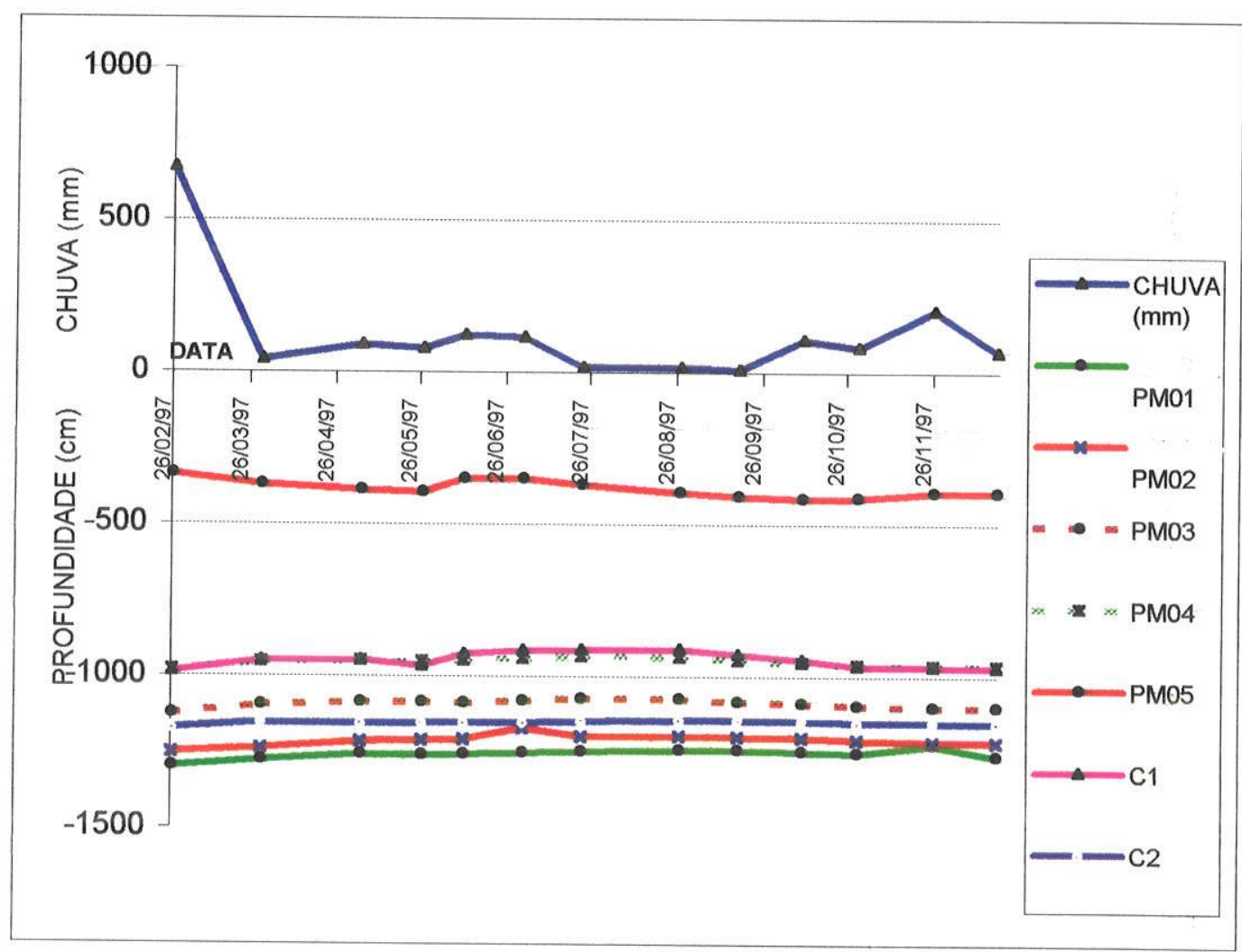

Figura 27: Variação da profundidade do topo do aqüifero livre - ano de 1997 
Tabela 22: Variação da profundidade do topo do aqüifero livre - ano de 1998

\begin{tabular}{|c|c|c|c|c|c|c|c|c|c|c|}
\hline DATA & $\begin{array}{c}\text { CHUVA } \\
\text { NO PERIODO } \\
(\mathrm{mm})\end{array}$ & $\begin{array}{l}\text { PM01 } \\
\text { PROF. } \\
\text { (cm) }\end{array}$ & $\begin{array}{l}\text { PM02 } \\
\text { PROF. } \\
\text { (cm) }\end{array}$ & $\begin{array}{l}\text { PM03 } \\
\text { PROF. } \\
\text { (cm) }\end{array}$ & $\begin{array}{l}\text { PM04 } \\
\text { PROF. } \\
\text { (cm) }\end{array}$ & $\begin{array}{l}\text { PMO5 } \\
\text { PROF. } \\
\text { (cm) }\end{array}$ & $\begin{array}{l}\text { PM06 } \\
\text { PROF. } \\
\text { (cm) }\end{array}$ & $\begin{array}{l}\text { PM07 } \\
\text { PROF. } \\
\text { (cm) }\end{array}$ & $\begin{array}{l}\text { C1 } \\
\text { PROF. } \\
\text { (cm) }\end{array}$ & $\begin{array}{l}\text { C2 } \\
\text { PROF. } \\
\text { (cm) }\end{array}$ \\
\hline 18/01/98 & 158,50 & -1260 & -1215 & -1106 & -964 & -409 & 558 & -638 & -981 & -1157 \\
\hline 08/02/98 & 25,00 & $-1267,5$ & -1222 & -1112 & -974 & -420 & -609 & -669 & -994 & 1160 \\
\hline 02/03/98 & 142,60 & -1273 & -1226 & -1117 & -975 & -417 & -597 & -689 & -1003 & 11164 \\
\hline $25 / 03 / 98$ & 127,40 & -1276 & -1229 & -1119 & -978 & -409 & 552 & -660 & -1007 & -1170 \\
\hline $22 / 04 / 98$ & 255,00 & -1251 & -1208 & -1108 & -971 & -371 & -522 & -511 & .980 & -1169 \\
\hline $27 / 05 / 98$ & 107,90 & -1261 & -1211 & -1091 & .956 & -380 & -581 & -586 & -969 & -1162 \\
\hline $24 / 06 / 98$ & 28,00 & -1255 & -1207 & -1088 & .952 & 397 & -607 & -644 & 980 & -1163 \\
\hline $27 / 07 / 5$ & 7,20 & 1257 & -1210 & 1096 & 959 & -412 & -638 & -687 & -995 & 1164 \\
\hline $17 / 08 / 98$ & 128,10 & 1257 & -1213 & -1099 & -963 & -402 & -594 & -677 & -1003 & -1163 \\
\hline
\end{tabular}

\begin{tabular}{|l|l|}
\hline-371 & PICO \\
\hline
\end{tabular}

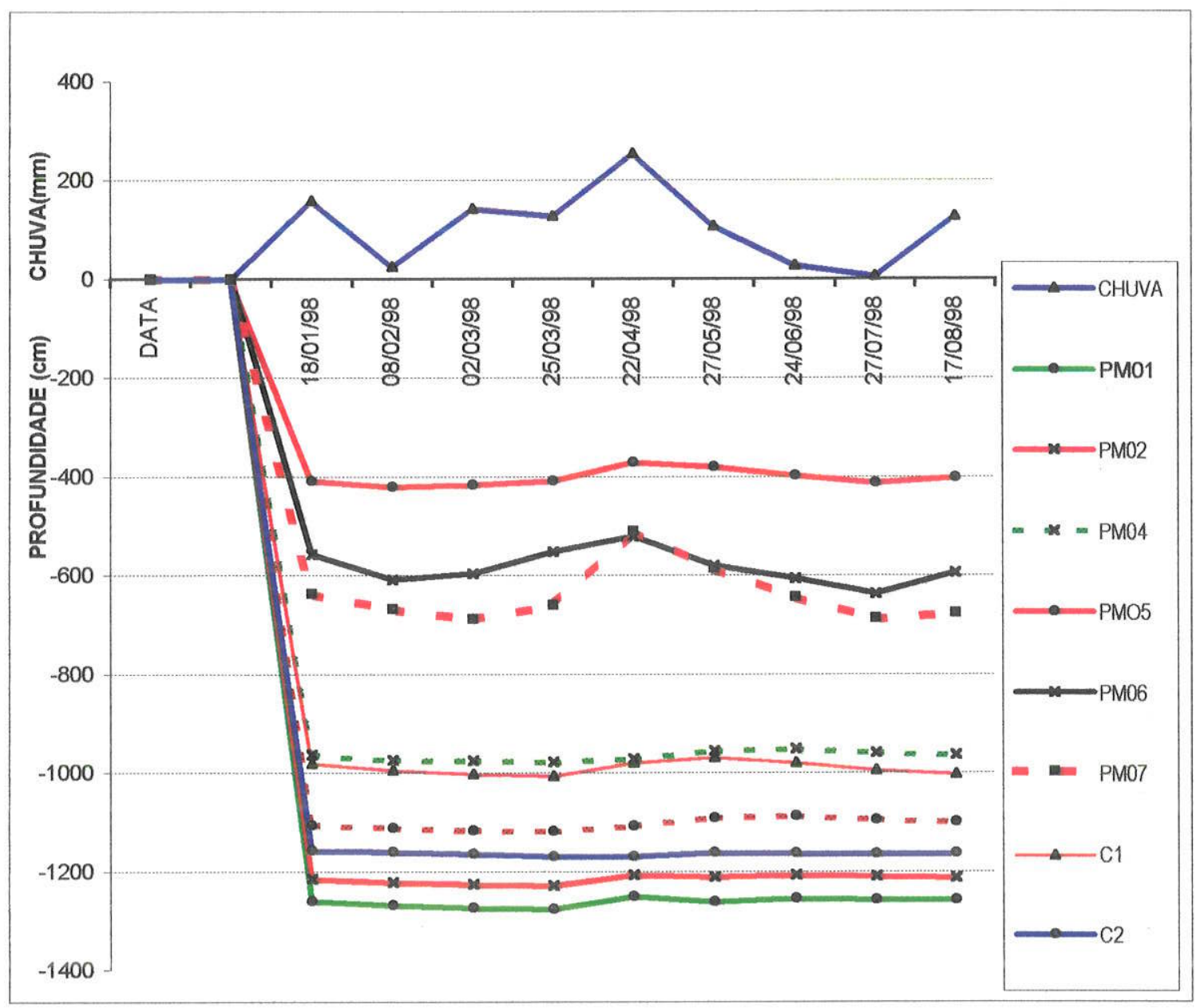

Figura 28: Variação da profundidade do topo do aqüifero livre - ano de 1998 
Quanto ao comportamento de nível freático durante o periodo de monitoramento, (Tabelas 20,21 e 22), os picos estão assim localizados:

$$
\begin{aligned}
& 1996 \text { - agosto-setembro (medição desde 11/05/96 ) } \\
& 1997 \text { - julho-agosto } \\
& 1998 \text { - abril e junho (medição até 17/08/98) }
\end{aligned}
$$

Os niveis mais baixos estão localizados em fevereiro e março.

Observa-se discordância deste comportamento com aquele verificado na área e adjacências nos anos de 1994 a 1995 (GODOY, 1997). Por estes dados anteriores, os picos aparecem em maio, com inversão mais acentuada em outubro.

Esta discordância dos últimos 3 anos e indefinição de ciclos deve ser atribuída ao comportamento da pluviosidade, com valores relativamente elevados de total de precipitaçăo, os quais foram:

$$
\begin{gathered}
1996-1.522,7 \mathrm{~mm} \\
1997-1.462,0 \mathrm{~mm} \\
1998-1.642,0 \mathrm{~mm},
\end{gathered}
$$

Estes valores são bem maiores que o valor médio de 1.312,7 mm entre $1969 \mathrm{e}$ 1995.

A distribuição da pluviosidade também foi discordante do que se observa no geral, com um total de $238,7 \mathrm{~mm}$ em junho de 1997 contra um valor total médio de $56,8 \mathrm{~mm}$, verificando-se outra discordância em março-abril de 1998, com um total de $495,4 \mathrm{~mm}$, contra o valor médio de $201 \mathrm{~mm}$.

As maiores variaçŏes de nivel no aqǘf́ero livre, por local de monitoramento, são verificadas nos poços PM06 e PM07, como era previsto pelas suas condiçð̃es de localização.

Os gráficos de oscilaçăo da profundidade do aqǘfero (Figuras 26, 27 e 28), apontam a ocorrência de respostas muito rápidas aos eventos de precipitação, o que 
indica uma influência em curto intervalo de tempo da pluviosidade e, portanto, uma recarga rápida.

No ano de 1996, este tipo de influência näo aparece nitidamente (Figura 26).

Quanto ao ano de 1997, o gráfico mostra a ocorrência de resposta rápida a eventos de precipitaçăo e estiagem, especialmente no tocante ao poço PM05, onde o topo da aqüífero é relativamente raso, sendo constatado com nitidez o reflexo da precipitação na recarga (Figura 27).

Quanto ao ano de 1998, o gráfico apresenta, para a maioria dos locais de monitoramento, um traçado paralelo das curvas referentes à variação da pluviosidade e à oscilação do nível freático, Deste modo, é evidenciado um efeito quase imediato de variações na pluviosidade no comportamento do nível freático. É importante observar que nos poços PM06 e PMO7, onde aparentemente a superfície de recarga é mais limitada, devido à presença da barreira mais espessa de estratos compactos, a resposta ocorre também em intervalo de tempo muito curto.

Foi analisada estatisticamente a correlação entre a pluviosidade e à posição do topo da zona saturada referentes aos locais de medição C1, C2, PM01, PM02, PM03, PM04 e PM05, expressa tanto em valores de profundidade como de cota. Foi aplicada a análise de regressão linear de determinação do coeficiente de Pearson, conforme é explicado por LANDIM (1998), com o tratamento de dados pelo programa Minitab versão 10.1. Nessa análise, a precipitação acumulada no período entre as medições foi considerada como variável independente. Infelizmente não foi possível, através deste recurso estatístico, definir uma correlação válida. Um dos motivos desta impossibilidade foi a necessidade de considerar um terceiro tipo de variável, que é a propagação do efeito das variações de pluviosidade através do fluxo da água na própria zona saturada. A contribuição dos aumentos de volume de água a montante do ponto de medição para as alterações de nivel neste mesmo ponto é um fator difícil de ser ponderado. No entanto, os gráficos apontam uma concordância nítida do comportamento das variaçőes de pluviosidade com a oscilação do nível freático.

No tocante à velocidade de infiltração da água na zona não saturada, os intervalos de valores apresentados por diferentes autores varia amplamente (CUSTODIO \& LLAMAS, 1990). Trata-se de uma questão complexa, porque deve ser considerada a influência de descontinuidades no fluxo da água subterrânea. Dentre estas descontinuidades, são incluídas as zonas de fraturamento e as cavidades de raízes mortas. 
Experimentos de determinações de velocidade de infiltração de água no terreno sob condições de clima subtropical úmido são relatados por POLI (1989). Os dados referem-se à área da Estação Experimental da USP e a uma área localizada no Município de Cajati - SP, tendo sido usado o trítio como traçador. No primeiro caso, é verificada a infiltração até $2,56 \mathrm{~m}$ de profundidade em 5 meses e no segundo, de 1,90 m em 11 meses.

Tomando-se como referência valores de velocidade de infiltração comparáveis a estes acima referidos, não é encontrada uma explicação para o fenômeno de recarga tão rápida como a observada na área em estudo.

Quanto às condições de drenagem no perfil do solo, de acordo com a variação do potencial mátrico ( vide Tabelas 14, 15 e 16), raramente, na maior parte do período de monitoramento, a condição de capacidade de campo se estendeu a todo o conjunto de horizontes.

Quanto ao componente da zona não saturada correspondente ao substrato rochoso, deve ser considerada a influência do fraturamento aí existente. O material rochoso, quanto às suas propriedades relacionadas à água subterrânea, é comumente classificado como "meio poroso" ou "meio fraturado". Trata-se, no entanto, de uma simplificação, restrita aos dois extremos extremos de uma ampla variedade de meios porosos/fraturados (CHERRY, 1984). Pelas informações resumidas no perfil litológico do poço tubular instalado a menos de $50 \mathrm{~m}$ de distância da EP , considera-se que, na área da pesquisa, na zona de substrato rochoso incluída na zona não saturada, é identificado um meio poroso/fraturado. Na regiäo de Presidente Prudente, são observados casos em que a estabilidade de pequenas obras hidráulicas, como represas de pequeno porte, é comprometida pela ocorrências de consideráveis fugas e perdas de água, devido ao fraturamento do arenito, sempre considerado como poroso. Esta omissão de fundamentação do projeto pode acarretar perda econômica muito grande em comparação com o orçamento da obra. Trata-se, portanto, de um fator de hidrodinåmica que deve ser investigado com atenção. 
5.4.3. Resultados Referentes ao Escoeme... . Superficial

A análise conjunta dos Tabelas 23 e 24 e das Figuras 30 e 31, dos registros dos pluviógrafos e dos dados de potencial mátrico aponta a influência da duração da chuva e do estado do solo no momento em que ela ocorre. A ocorrência de chuva torrencial, volumosa e concentrada em poucas horas, sobre solo onde o horizonte superior está todo saturado, favorece o escoamento superficial da água. Devido a este fator de aumento episódico, é complexa a determinação da parcela da precipitação convertida em escoamento superficial.

Tabela 23: Medidas do escoamento superficial - 1997

\begin{tabular}{|c|c|c|c|c|c|}
\hline DATA & $\begin{array}{c}\text { DIAS DE } \\
\text { CHUVA }\end{array}$ & $\begin{array}{c}\text { TOTAL DE } \\
\text { CHUNA NO } \\
\text { CANTEIRO(L) }\end{array}$ & $\begin{array}{c}\text { DEFLÚVIO } \\
\text { MEDIDO } \\
(\text { L })\end{array}$ & $\begin{array}{c}\text { ESTADO } \\
\text { DO SOLO }\end{array}$ & $\begin{array}{c}\text { RELAÇÁO } \\
\text { DEFLÚVIO/ } \\
\text { CHUVA (\%) }\end{array}$ \\
\hline $12 / 06 / 97$ & $11 \mathrm{e} 12 / 06 / 97$ & 2455 & 369,31 & muito úmido & 15,04 \\
\hline $15 / 06 / 97$ & $14 \mathrm{e} 15 / 6 / 97$ & 2375 & 317,52 & muito úmido & 13,37 \\
\hline $29 / 06 / 97$ & $29 / 06 / 97$ & 460 & 12,87 & muito úmido & 2,80 \\
\hline $21 / 07 / 97$ & $21 / 07 / 97$ & 895 & 0 & muito úmido & 0,00 \\
\hline $20 / 09 / 97$ & $20 / 09 / 97$ & 660 & 0 & seco & 0,00 \\
\hline $26 / 09 / 97$ & $24 a 26 / 9 / 97$ & 1470 & 38,6 & seco & 2,63 \\
\hline $01 / 10 / 97$ & $29 / 9 a 1 / 10 / 97$ & 2685 & 812,94 & seco- úmido & 30,28 \\
\hline $17 / 10 / 97$ & $16 e 17 / 10 / 97$ & 855 & 0 & úmido $\rightarrow$ seco & 0,00 \\
\hline $30 / 10 / 97$ & $30 / 10 / 97$ & 570 & 67,56 & muito úmido & 11,85 \\
\hline $14 / 11 / 97$ & $13 e 14 / 11 / 97$ & 1335 & 20,26 & muito úmido & 1,52 \\
\hline $26 / 11 / 97$ & $26 / 11 / 97$ & 885 & 12,87 & muito úmido & 1,45 \\
\hline
\end{tabular}

ESTADO
DO SOLO acordo com medidas dos
tensiômetros

A determinaçăo da parcela de água que escoa deste modo é útil em experimentos onde a determinaçăo do balanço hídrico real entra como um componente importante. Para a finalidade de avaliação de recarga de um aqüífero, os resultados obtidos através de um canteiro de deflúvio estáo sujeitas a ressalvas, uma vez que as particularidades de relevo e de ocupaçăo do terreno interferem no desenvolvimento da 
drenagem superficial. Numa área que tem caracteristicas semelhantes às do Campus da UNESP em Presidente Prudente, o comportamento da água que escoa por sobre o terreno é influenciado por fatores do meio ambiente, de diferentes naturezas, tais como a presença de raízes de árvores expostas, regos de drenagem superficial, embaciamentos do terreno, sulcos de terraceamento e a cobertura vegetal rasteira.

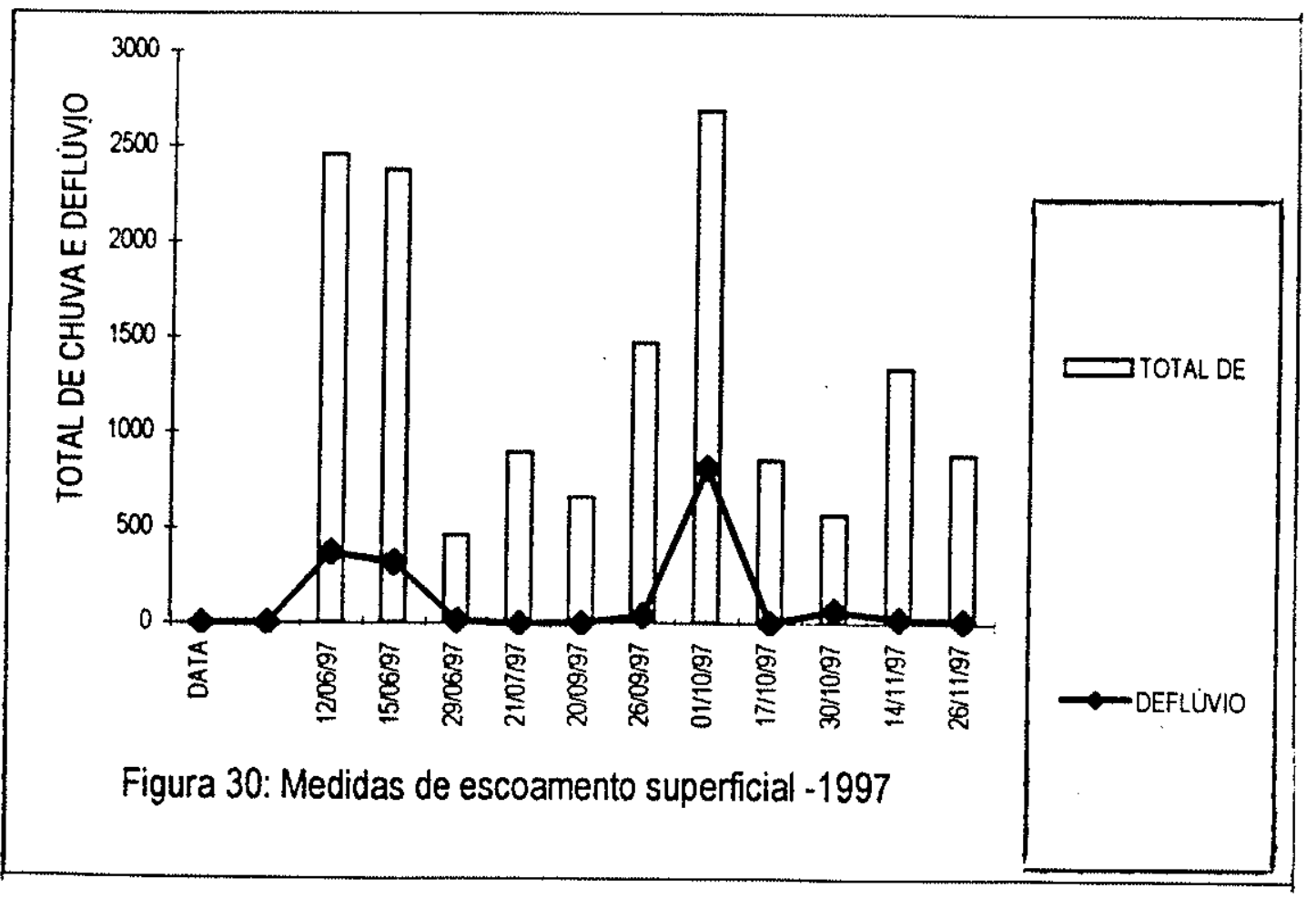


Tabela 24: Escoamento superficial - 1998

\begin{tabular}{|c|c|c|c|c|c|c|}
\hline DATA & $\begin{array}{l}\text { DIASDE } \\
\text { CHUVA }\end{array}$ & $\begin{array}{l}\text { CHUVA } \\
\text { MEDIA } \\
(\mathrm{mm})\end{array}$ & $\begin{array}{l}\text { CHUNA } \\
\text { NO CANIEIRO } \\
\text { (l) }\end{array}$ & DEFLUVO & $\begin{array}{l}\text { ESTAOO } \\
\text { DO SOLO }\end{array}$ & $\begin{array}{l}\text { RELACAO } \\
\text { DEFLUVIO } \\
\text { CHUVA (\%) }\end{array}$ \\
\hline $04 / 01 / 98$ & $17 / 01 / 98$ & 78,1 & 3905 & 760,60 & úmido & 19,48 \\
\hline $13 / 01 / 98$ & $13 / 01 / 98$ & 6,2 & 310 & 64,00 & multo úmido & 20,65 \\
\hline $07 / 02 / 98$ & $1-7 / 2 / 98$ & 18,4 & 920 & 0,00 & seco & 0,00 \\
\hline $26 / 02 / 98$ & $21-26 / 2 / 98$ & 29 & 1450 & 57,91 & seco & 3,99 \\
\hline $02 / 03 / 98$ & $1.2 / 3 / 98$ & 68,7 & 3435 & 218,76 & muito úmido & 6,37 \\
\hline $06 / 03 / 98$ & $06 / 03 / 98$ & 20,3 & 1015 & 88,47 & muito úmido & 8,72 \\
\hline $08 / 03 / 98$ & $08 / 03 / 98$ & 9,4 & 470 & 0,00 & muito úmido & 0,00 \\
\hline $21 / 03 / 98$ & $20-21 / 3 / 98$ & 29,6 & 1480 & 144,77 & muito úmido & 9,78 \\
\hline $22 / 03 / 98$ & $22 / 03 / 98$ & 9,8 & 490 & 143,16 & muito úmido & 29,22 \\
\hline $30 / 03 / 98$ & $28-30 / 3 / 98$ & 143,9 & 7195 & 218,76 & muito úmido & 3,04 \\
\hline $01 / 04 / 98$ & $01 / 04 / 98$ & 25,1 & 1255 & 125,46 & muito úmido & 10,00 \\
\hline $05 / 04 / 98$ & 4.5/04/1998 & 21,9 & 1095 & 0,00 & muito úmido & 0,00 \\
\hline $07 / 04 / 98$ & $07 / 04 / 98$ & 23,1 & 1155 & 62,73 & muito úmido & 5,43 \\
\hline $17 / 04 / 98$ & $16-17 / 04 / 1998$ & 39,2 & 1960 & 29,60 & muito úmido & 1,51 \\
\hline $28 / 04 / 98$ & $28 / 04 / 98$ & 24,6 & 1230 & 164,07 & muito úmido & 13,34 \\
\hline $04 / 05 / 98$ & $04 / 05 / 98$ & 40,5 & 2025 & 16,09 & muito úmido & 0,79 \\
\hline $15 / 05 / 98$ & $14-15 / 5 / 98$ & 19,5 & 975 & 31,53 & muito úmido & 3,23 \\
\hline $30 / 05 / 98$ & $29-30 / 5 / 98$ & 21,6 & 1080 & 65,95 & muito úmido & 6,11 \\
\hline $05 / 08 / 98$ & $4-5 / 8198$ & 15,7 & 785 & 86,86 & úmido & 11,06 \\
\hline $10 / 08 / 98$ & $8-10 / 8 / 98$ & 59,9 & 2995 & 41,18 & úmido & 1,37 \\
\hline $14 / 08 / 98$ & $14 / 08 / 98$ & 41,8 & 2090 & 152,81 & úmido & 7,31 \\
\hline $19 / 08 / 98$ & $19 / 08 / 98$ & 19,4 & 970 & 26,38 & úmido $>\operatorname{seco}$ & 2,72 \\
\hline
\end{tabular}

ESTADO DO SOLO de acondo com os dados dos tensiómetros

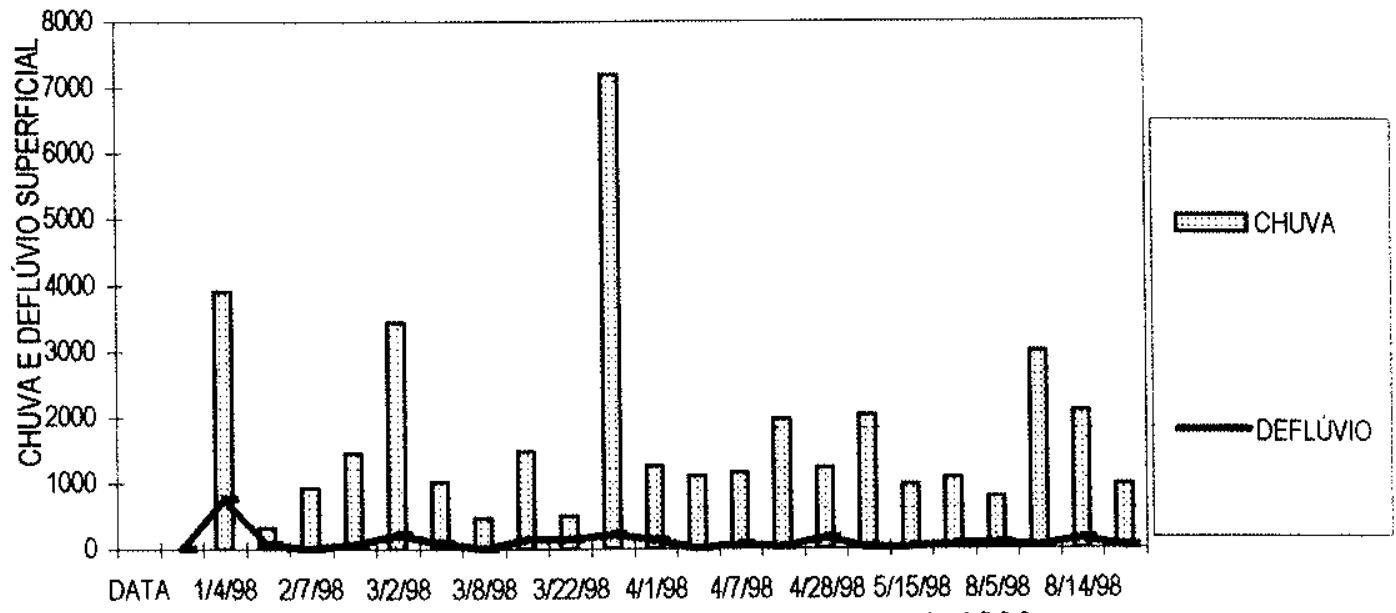

Figura 31: Gráfico chuva x escoamento superficial - 1998 


\subsection{ZONEAMENTO REFERENTE À HIDRODINÂMICA}

Em função das condições intrínsecas do meio físico e da história de ocupação do terreno, pelo menos 5 zonas já se distinguem na carta em escala 1:1.000 (Figura 19), sendo delimitadas de forma simplificada na Figura 32. São elas:

1 - Zona do pomar, ocupada em parte com horticultura; declividade de 3 a $9 \%$ da encosta; solo podzólico, de horizontes não muito nitidamente diferenciados; regolito de espessura variável entre $3 \mathrm{~m}$ e $5 \mathrm{~m}$; influência característica de cavidades de raízes mortas na hidrodinámica do solo; topo do aqüífero a profundidade variável entre $9 \mathrm{~m}$ e $13,5 \mathrm{~m}$.

2 - Zona exterior ao pomar, em embaciamento do terreno, onde se localiza o depósito de lixo de laboratório e o poço de monitoramento PM05; declividade de 9 as $17 \%$ da encosta; solo podzólico; espessura do regolito entre 0,5 $\mathrm{m}$ e $3,5 \mathrm{~m}$; topo da zona saturada a profundidades variáveis entre $3,5 \mathrm{~m}$ e $9 \mathrm{~m}$.

3 - Zona de início de uma ravina, onde se localiza um açude; declividade de 12 a $45 \%$ na encosta; solo podzólico mais raso e com hidromorfismo; espessura do regolito entre $0,5 \mathrm{~m}$ e $2 \mathrm{~m}$; topo do aqüifero livre a profundidades variáveis entre $0 \mathrm{~m}$ e $4,5 \mathrm{~m}$.

4 - Zona de declive mais acentuado, onde se encontra o poço de monitoramento PM06; declividade de 11 a 40\% na encosta; maior presença de estratos compactos no substrato rochoso; solo litólico; surgências e ressudações de água; topo da zona saturada a profundidade variável entre $5 \mathrm{~m} \mathrm{e}$ $6 \mathrm{~m}$; interferência antrópica do terraceamento e de repovoamento de vegetação. 
5 - Zona do terço inferior da encosta, onde se encontra o poço de monitoramento PM07; declividade de 6 a 17\% na encosta; solo litólico; interferéncia antrópica de terraceamento e repovoamento vegetal; topo da zona saturada a profundidade variável entre $5 \mathrm{me} 7 \mathrm{~m}$.

No zoneamento, é verificada a diferenciação de ambientes com base em detalhes de suas características, o que tem importância do ponto de vista do comportamento da água subterrânea. As principais distinções correspondem a variações no declive e na forma da superfície do terreno, nas associações litológicas e pedológicas, na espessura do solo, na profundidade e no comportamento do aqüifero, à cobertura vegetal diversificada e à heterogeneidade da interferência antrópica no meio considerado. Devem ser admitidas diferenças de uma zona para outra, no grau de contribuição de diversas variáveis para o comportamento do ambiente tanto por setor de área como em profundidade.

No aspecto da influência da estrutura sedimentar, a representação em perfil orientado na direção $87^{\circ} 43^{\prime} 56^{\prime \prime} \mathrm{NE}-\mathrm{SW}$, identificada (Figura 33), ressalta a existência de estratos de arenito e lamito compactos. Quanto à atuação destas camadas como barreiras à percolação, distingue-se mais nitidamente uma delas, que aflora no setor onde a declividade atinge seu maior valor (30-45\%), que corresponde à zona 4, estando, portanto, localizada entre os poços PM05 e PM06 e entre as cotas 415 e 420 $\mathrm{m}$.

Adotando-se a altitude como referência, é estabelecida uma correlação entre as variações na compacidade, constatadas nos poços de monitoramento e em afloramentos rochosos, com as informações do perfil litológico do poço tubular, que são obtidas de testemunhos de perfuração. De acordo com perfil do poço, no entanto, a característica de cimentação relativamente alta é mantida regularmente, exceto emalgumas intercalações pouco representativas de rocha friável, da cota $400 \mathrm{~m}$ à cota $420 \mathrm{~m}$, em concordância com os limites verticais da Zona 4 . 

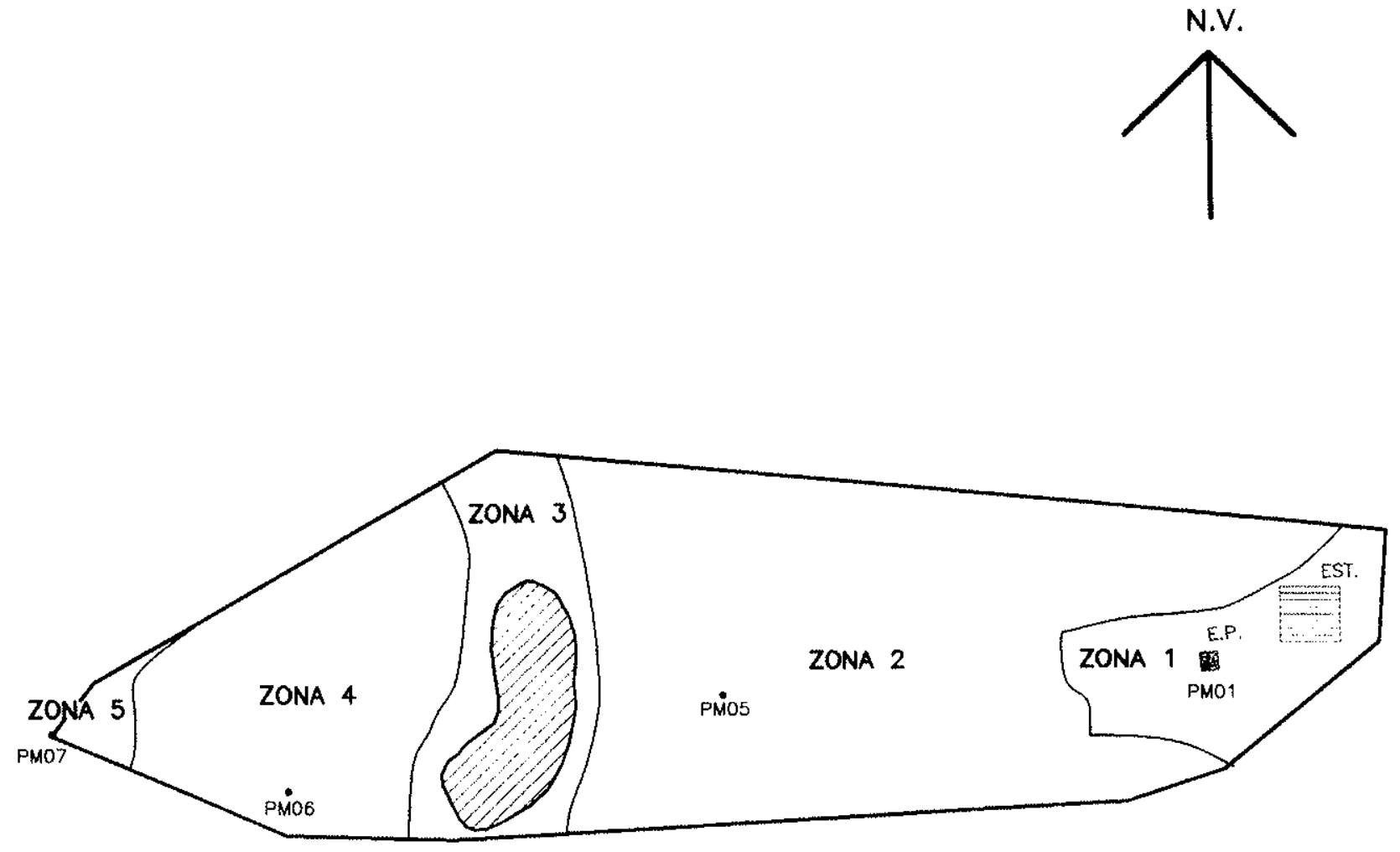

ESCALA $1: 2.500$

\begin{tabular}{|c|c|}
\hline & LEGENDA \\
\hline PMOE & POÇO DE MONITORAMENTO \\
\hline E.P. & ESTAÇÃO PILOTO \\
\hline$\Longrightarrow$ EST. & ESTUFA \\
\hline 领 & AÇUDE \\
\hline
\end{tabular}

Figura 32 : Zoneamento do meio ambiente na área da pesquisa com base em características hidrodinâmicas, hidroquímicas e de interferência antrópica 


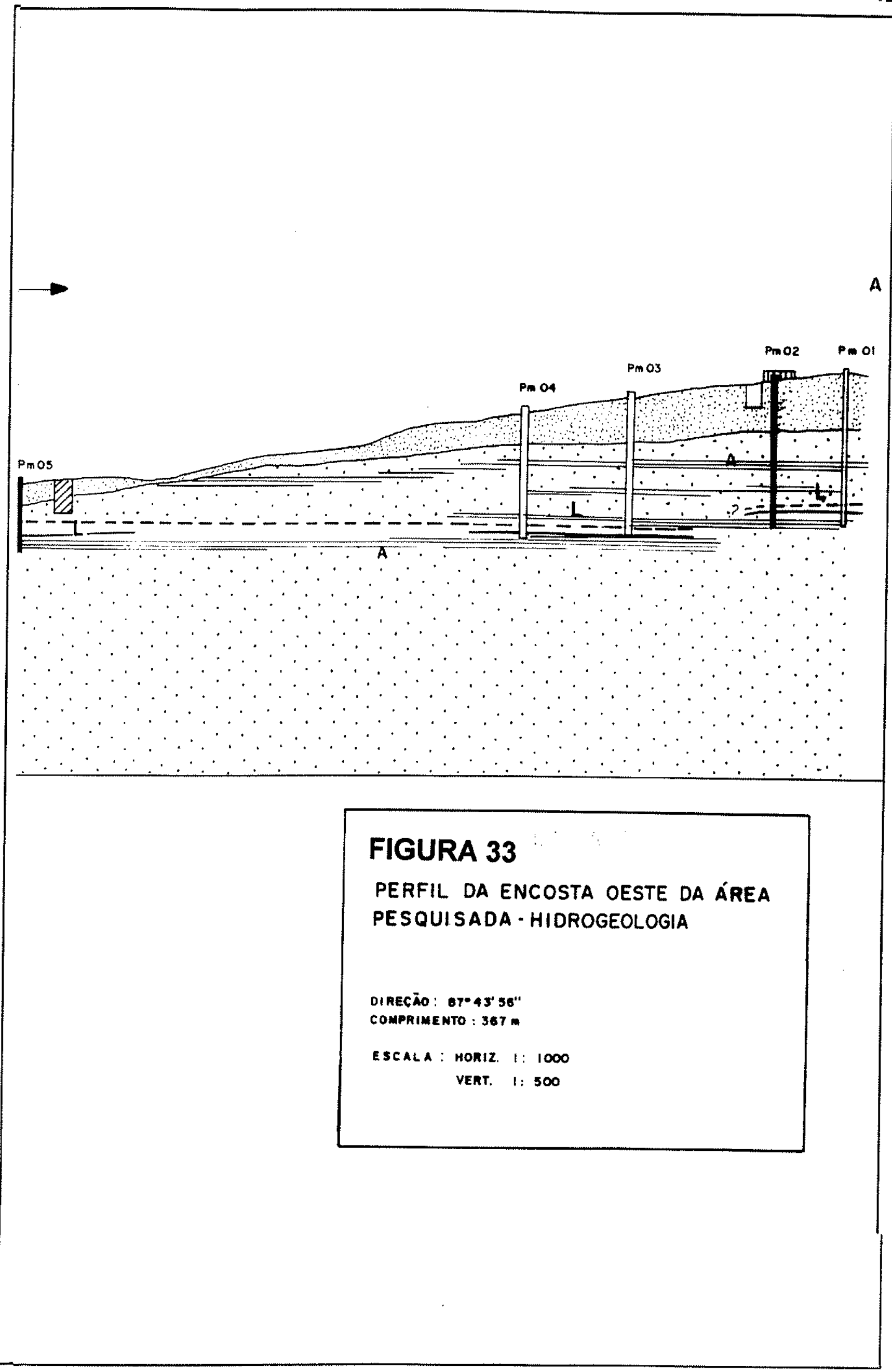


A constataçăo da presença de aqüiferos suspensos na área é apoiada na observação de amostras de testemunhos. Os contrastes de textura e grau de cimentação verificados em toda a extensão dos testemunhos correspondem a diferentes zonas de saturação em todo o perfil do poço. Um outro indício destas descontinuidades verticais de aqüífero é o fenómeno de "cachoeira", que ainda ocorre atualmente em um poço desativado e localizado a cerca de $160 \mathrm{~m}$ de distância da EP.

Pelo perfil litológico do poço tubular e de afloramentos rochosos, deduz-se que na encosta, onde estão instalados os poços de monitoramento e entre a superfície e a profundidade de $3 \mathrm{~m}$ pelo menos, por influência do intemperismo, o grau de compacidade dos termos areníticos e lamíticos foi reduzida com a perda de cimento e com o fraturamento.

Um detalhe de ocorrencia de camadas de lamito compacto entre as cotas 412 e $420 \mathrm{~m}$, intermediando os poços PMO6 e PM07, deve ser considerado também. Conforme se representa no perfil, um estrato atua como controle estrutural da água subterrânea.

\subsection{RESULTADOS DE ANÁLISES QUÍMICAS}

\subsubsection{Apresentação dos Resultados}

As tabulação apresentam conjuntamente os dados do que é próprio da etapá relativa ao "background" e os referentes à etapa seguinte, devido a mudanças de desenvolvimento da pesquisa. Na tabulação dos resultados, é realçada a separação entre o que ocorreu antes e dois do vazamento do esgoto sanitário. 
As tabulaçöes referem-se a:

- resultados de análises químicas da água - realizadas no laboratório de Hidroquímica do CEPAS/IGUSP e correspondentes a coletas periódicas;

- resultados de análises químicas da água - realizadas em laboratório do Campus da UNESP de Presidente Prudente;

- resultados de análises químicas do solo com referência a elementos metálicos retidos;

Outras informações referentes a análise química da água são:

- resultado de análises químicas de água residuária, proveniente do conduto rompido - realizadas em laboratório da SABESP;

- resultado de análises químicas de 2 amostras de água coletada no açude realizadas em laboratório da CETESB;

\subsubsection{Alteração no Projeto de Monitoramento Hidrogeoquímico}

Inicialmente, a proposição hidrogeológica foi medir, durante 1 ano hidrológico, o "background" hidrogeoquímico, para depois introduzir uma carga contaminante no sistema hídrico pesquisado e desenvolver uma nova etapa do monitoramento. Para essa etapa experimental, foram escolhidos, como carga contaminante, rejeitos semitratados da indústria coureira, provenientes do Curtume São Paulo S. A., em decorrência de uma solicitação deste.

Infelizmente, após 10 meses e 2 semanas de monitoramento, aconteceu um acidente ambiental, através do rompimento de um coletor de água residuária nas pro 
ximidades da EP. Esses rejeitos do sistema de esgoto foram lançados diretamente no solo, com infiltraçăo imediata, durante 26 dias.

A respeito da presença deste conduto enterrado, deve ser reconhecido que se trata de um sistema de esgoto semi-clandestino, uma vez que o projeto da sua instalação não foi localizado em nenhum documento oficial da Prefeitura Municipal de Presidente Prudente.

Como a presença deste tipo de coletor clandestino é mais freqüente do que se presume, foi proposto para a entidade financiadora do projeto uma campanha de varredura com o Ground Penetrating Radar - GPR, método geofísico apropriado e com recursos especialmente capazes de tanto, para detectar tubulações subterrâneas a distância relativamente pequena da superficie. Infelizmente, como se trata de um método ainda custoso, a sua execução não foi aprovada. Assim sendo, é válido entender que qualquer avaliação ambiental ou "auditoria ambiental" com o emprego deste método deveria ocorrer, tanto na área de pesquisa como em outro projeto similar.

\subsubsection{Interpretação dos Resultados}

5.6.3.1.Resultados de análise estatística

As análises comparativas de teores foram aplicadas a alguns ions, conforme se resume no Quadro 10.

Quadro 10 : Identificaçăo dos resultados de análise química selecionados para a aplicação de testes estatísticos

\begin{tabular}{|l|l|}
\hline \multicolumn{1}{|c|}{ ION } & \multicolumn{1}{|c|}{ PONTO DE COLETA } \\
\hline $\begin{array}{l}\mathrm{NO}_{3}{ }^{-}, \mathrm{Cl}^{-} \text {e } \mathrm{Na}^{+}, \mathrm{Fe} \\
\mathrm{SO}_{4}{ }^{2-}\end{array}$ & $\begin{array}{l}\text { PM01, PM02, PM03, PM04, PM05, PM06, } \\
\text { PM07, C2 e Poço Tubular }\end{array}$ \\
\hline
\end{tabular}

Quanto ao procedimento, foi necessário optar pela análise não paramétrica, de acordo com CONOVER (19ع ', porque os dados não apresentam distribuição normal. 
Foi adotado o teste de Kruskall-Wallis, com nível de significáncia de 5\%, com base nas seguintes suposiçōes:

- todas as amostras são amostras aleatórias de suas respectivas populações;

- existe independência mútua entre as várias amostras;

- a escala das medidas é ordinal.

Os números de medidas utilizados estão na Tabela 25.

Tabela 25 : Números de medidas utilizados no teste estatistico referente aos dados de análises químicas

\begin{tabular}{|c|c|c|c|}
\hline Pontos & $\begin{array}{c}\text { NOBS } \\
\mathrm{NO}_{3}{ }^{-}\end{array}$ & $\begin{array}{c}\text { NOBS } \\
\mathrm{SO}_{4}{ }^{2-}\end{array}$ & $\begin{array}{c}\mathrm{NOBS} \\
\mathrm{Cl}^{-}, \mathrm{Na}^{+}, \mathrm{F}^{-}\end{array}$ \\
\hline PM01 & 8 & 8 & 8 \\
\hline PM02 & 9 & 8 & 8 \\
\hline PM03 & 8 & 8 & 8 \\
\hline PM04 & 9 & 9 & 9 \\
\hline PM05 & 9 & 9 & 9 \\
\hline PM06 & 2 & 2 & 2 \\
\hline PM07 & 3 & 2 & 2 \\
\hline C2 & 6 & 6 & 6 \\
\hline PoçO Tubular & 6 & & 6 \\
\hline TOTAL & 60 & 52 & 58 \\
\hline
\end{tabular}


Resultados:

Para $\mathrm{NO}_{3}{ }^{\circ}: \mathrm{T}=33,17$ e d.f. $=8$

Conclusão: com um nível de significância de de $5 \%$, é constatado que existe diferença entre os poços de monitoramento e o poço tubular; os poços PM01, PM02, PM03 e PM04 não apresentam diferença em relação à cacimba $\mathrm{C} 2$.

Para $\mathrm{SO}_{4}{ }^{2-}: \mathrm{T}=47,38$ e d.f. $=7$

Conclusão: com um nível de significância de de $5 \%$, é constatado que existe diferença entre os os poços PM01, PM02, PM03, PM04, Pm06, Pm07 e a cacimba $\mathrm{C} 2$ em relação ao poço $\mathrm{PM} 05$.

Para Cl": $T=38,48$ e d.f. $=8$

Conclusão: com um nivel de significância de de $5 \%$, é constatado que existe diferença entre todos os poços de monitoramento e o poço tubular em relação à cacimba $\mathrm{C} 2$.

Para $\mathrm{Na}^{+}: \mathrm{T}=24,38$ e d.f. $=8$

Conclusão: com um nivel de significância de de $5 \%$, é constatado que existe diferença entre os poços de monitoramento e o poço tubular; os poços PM01, PM03 e PM04 diferem significativamente do poço tubular; os poços PM01e a cacimba C2 não apresentam diferença entre si.

Para $F^{\cdot}: T=14,55$ e d.f. $=8$

Conclusão: com um nível de significância de de $5 \%$, é constatado que não existe diferença entre todos os poços de monitoramento e cacimba C2. 


\subsubsection{Resultados referentes à zona não saturada}

Tanto em relação aos dados de amostragem anterior do vazamento da água residuária e correspondente ao "background", quanto os dados posteriores posteriores ao vazamento, os resultados da análise química referente à água extraída do solo são muito pouco numerosos para uma discussão e avaliação. As amostras obtidas com os extratores de cápsula porosa foram em número de 8 , tendo uma delas, colhida no antigo parreiral, à profundidade de $0,20 \mathrm{~m}$, a quantidade de cerca de $10 \mathrm{~cm}^{3}$.

Tabeia 26: Resultados de análise química referente a amostras dos extratores de cápsula porosa

\begin{tabular}{|c|c|c|c|c|c|c|c|c|}
\hline PROF.(m) & 0,20 & 1,00 & 4,00 & 0,50 & \multicolumn{4}{|c|}{$\begin{array}{lllllllll} & A & R & R & E & I & R & A & L \\
\end{array}$} \\
\hline & & & & & & $0,20 \mathrm{~m}$ & $0,50 \mathrm{~m}$ & $0,90 \mathrm{~m}$ \\
\hline DATA & $\begin{array}{l}29 / 4 / 97 \\
\text { Durante } \\
\text { Vazam. }\end{array}$ & $\begin{array}{r}12 / 6 / \\
23 \\
\text { após }\end{array}$ & $\begin{array}{l}97 \\
\text { dias } \\
\text { vazam. }\end{array}$ & $\begin{array}{r}7 / 4 / \\
\text { Durante } \\
\text { vaza }\end{array}$ & $\begin{array}{l}98 \\
\text { novo } \\
\text { mento }\end{array}$ & $\begin{array}{r}7 / 4 / \\
\text { pert o }\end{array}$ & $\begin{array}{r}98 \\
\mathrm{~d} a \\
\mathrm{est} \\
\end{array}$ & $\mathrm{ufa}$ \\
\hline $\begin{array}{c}10 \mathrm{~N} \\
(\mathrm{mg} / \mathrm{L})\end{array}$ & & & & & & & & \\
\hline $\mathrm{Ca}^{2+}$ & 32,2 & 16,8 & 13,95 & 44,00 & 24,10 & 270,80 & 53,33 & 32,80 \\
\hline $\mathrm{Mg}^{2+}$ & 6,28 & 2680,0 & 40,75 & 392,00 & 21,88 & ND & 14,44 & 9,20 \\
\hline $\mathrm{Ba}^{2+}$ & 0,25 & 0,16 & 0,04 & 0,20 & 2,23 & 1666,66 & $\mathrm{ND}$ & 0,20 \\
\hline $\mathrm{Cu}^{2+}$ & ND & 6,64 & 0,06 & 0,05 & $\mathrm{ND}$ & 1,67 & 0,33 & 0,14 \\
\hline $\mathrm{Zn}^{2+}$ & 0,09 & 0,76 & 0,02 & 0,23 & 7,51 & 2,00 & 1,06 & 0,58 \\
\hline $\mathrm{Na}^{+}$ & 7,00 & 10,00 & 1,2 & 12,00 & 6,00 & $\mathrm{ND}$ & ND & ND \\
\hline $\mathrm{K}^{+}$ & 19,00 & 20,00 & 8,0 & $\mathrm{ND}$ & 16,00 & ND & ND & ND \\
\hline$F$ & 1,69 & 2,15 & 0,12 & 1,00 & 5,01 & 3,85 & 8,44 & 4,06 \\
\hline $\mathrm{Cl}^{-}$ & 15,77 & 8,04 & 0,66 & 8,59 & 11,19 & 78,65 & 29,84 & 22,66 \\
\hline $\mathrm{NO}_{3}$ & 8,19 & 1,85 & 0,81 & 4,29 & 6,28 & 16,49 & 7199 & 8939 \\
\hline $\mathrm{PO}_{4}^{3}$ & 1,52 & 7,68 & 0,84 & 0,10 & 11,14 & 0,21 & 0,31 & 0,19 \\
\hline $\mathrm{SO}_{4}{ }^{2-}$ & 6,07 & 11,40 & 1,05 & 11,69 & 24,65 & 15,14 & 13,02 & 7,97 \\
\hline
\end{tabular}

$$
8,04 \text { > MEDDIA }
$$$$
12,00 ? \gg \text { MÉDIA }
$$ 
No caso de algumas amostras, as análises químicas apresentam teores muito elevados de $\mathrm{Ca}^{+}, \mathrm{Mg}^{+}, \mathrm{Ba}^{2+}, \mathrm{Cu}^{2+}$ (Tabela 26), que devem sero considerados para os 3 primeiros destes elementos.

Para a amostra coletada na área do antigo parreiral a $1 \mathrm{~m}$ de profundidade a 12/06/97, foi determinado o valor de $6,84 \mathrm{mg} / \mathrm{L}$ para teor de $\mathrm{Cu}^{2+}$, considerado como relativamente elevado. Neste caso, é admitida a hipótese de contaminação do solo por uso de agrotóxicos no antigo parreiral.

Tabela 27 : Teor de metais de extrato de solo e rocha

\begin{tabular}{|c|c|c|c|c|c|c|c|}
\hline LOCAL & $\begin{array}{c}\text { AMOS- } \\
\text { TRA }\end{array}$ & $\begin{array}{c}\mathrm{Zn} \\
(\mathrm{ppm})\end{array}$ & $\begin{array}{c}\text { Mn } \\
\text { (ppm) }\end{array}$ & $\begin{array}{c}\mathrm{Fe} \\
(\mathrm{ppm})\end{array}$ & $\begin{array}{c}\mathrm{Cr} \\
(\mathrm{ppm})\end{array}$ & $\begin{array}{c}\mathrm{Cu} \\
(\mathrm{ppm})\end{array}$ & $\begin{array}{c}\mathrm{Ba} \\
\text { (ppm) }\end{array}$ \\
\hline \multirow{6}{*}{$\begin{array}{l}\text { TRIN- } \\
\text { CHEI- } \\
\text { RA T1 }\end{array}$} & $A p$ & $<0,01$ & 0,049 & 0,01 & $<0,02$ & $<0,02$ & 0,077 \\
\hline & A3 & $<0,01$ & 0,014 & 2,00 & $<0,02$ & $<0,02$ & 0,023 \\
\hline & B1t & $<0,01$ & 0,010 & 0,28 & $<0,02$ & $<0,02$ & 0,041 \\
\hline & B2t & $<0,01$ & $<0,005$ & 0,77 & $<0,02$ & $<0,02$ & 0,007 \\
\hline & $\mathrm{BC}$ & $<0,01$ & 0,005 & 0,08 & $<0,02$ & $<0,02$ & 0,016 \\
\hline & $C$ & $<0,01$ & $<0,005$ & 0,03 & $<0,02$ & $<0,02$ & 0,008 \\
\hline \multirow{6}{*}{$\begin{array}{l}\text { PAR- } \\
\text { REI- } \\
\text { RAL }\end{array}$} & $A p$ & $<0,01$ & $<0,005$ & 0,02 & $<0,02$ & $<0,02$ & 0,019 \\
\hline & A3 & $<0,01$ & 0,021 & 0,19 & $<0,02$ & $<0,02$ & 0,010 \\
\hline & B1t & $<0,01$ & 0,005 & 0,23 & $<0,02$ & $<0,02$ & 0,004 \\
\hline & $\mathrm{B} 2 \mathrm{t}$ & $<0,01$ & 0,022 & 0,01 & $<0,02$ & $<0,02$ & 0,024 \\
\hline & $\mathrm{BC}$ & $<0,01$ & 0,022 & 0,01 & $<0,02$ & $<0,02$ & 0,019 \\
\hline & $C$ & $<0,01$ & $<0,005$ & 0,01 & $<0,02$ & $<0,02$ & $<0,004$ \\
\hline \multirow{3}{*}{ PMO2 } & $3-4 m$ & $<0,01$ & $<0,005$ & $<0,01$ & $<0,02$ & $<0,02$ & $<0,004$ \\
\hline & $10-11 \mathrm{~m}$ & $<0,01$ & 0,009 & 0,71 & $<0,02$ & $<0,02$ & $<0,004$ \\
\hline & $11-12 m$ & $<0,01$ & 0,005 & 0,38 & $<0,02$ & $<0,02$ & $<0,004$ \\
\hline \multirow{3}{*}{ PM05 } & $3-3,5 \mathrm{~m}$ & $<0,01$ & $<0,005$ & 0,01 & $<0,02$ & $<0,02$ & $<0,004$ \\
\hline & $4-4,2 \mathrm{~m}$ & $<0,01$ & 0,008 & 0,24 & $<0,02$ & $<0,02$ & 0,006 \\
\hline & $4,2-4,4 m$ & $<0,01$ & 0,008 & 0,94 & $<0,02$ & $<0,02$ & 0,011 \\
\hline
\end{tabular}


A análise química do solo e de algumas camadas mais argilosas do substrato rochoso (Tabela 27 ) năo confirmou a presença de $\mathrm{Cu}$, năo sendo detectada também a existência de $\mathrm{Ba}, \mathrm{Cr}, \mathrm{Zn}$, tanto na forma de íons como em qualquer tipo de combinaçăo. Foi detectada a presença de Mn e Fe (combinados ou como ions) em teores considerados como próprios de um solo tropical em sua condiçăo natural.

Em amostras de extratores localizados na área correspondente ao antigo parreiral, de 0,50m e 0,90m de profundidade, foram obtidos valores de $\mathrm{NO}_{3}{ }^{-}$foram 71,99 $\mathrm{mg} / \mathrm{L}$ e $89,39 \mathrm{mg} / \mathrm{L}$ respectivamente (coleta de 07/04/98), bem mais elevados que os de outros locais Uma condição que diferencia este local de outros locais de amostragem por extratores é a sua proximidade da estufa, a qual recebe adubação de origem animal.

5.6.3.3. Resultados das análises referentes ao aqüífero freático

A-Condutividade elétrica, $\mathrm{pH}, \mathrm{CO}_{3}{ }^{2-}$ e $\mathrm{HCO}_{3}{ }^{\circ}$

Quanto às medidas de condutividade elétrica ( Tabela 28), os valores mais elevados que a média referem-se ao esgoto, ao poço tubular e à cacimba C2, podendo deste modo ser correlacionada à maior presença de sais dissolvidos na água coletada nestes locais, notadamente o valores relativamente mais elevados de $\mathrm{Na}^{+}$e $\mathrm{Cr}$. $\mathrm{Em}$ contraste, a água da chuva, menos mineralizada que a água subterrânea, apresenta os menores valores.

Valores de $\mathrm{pH}$ ácido ( 5 a 6 ) foram determinados para os poços de monitoramento. São ligeiramente mais ácidos do que os obtidos com as amostras de chuva, contrariando o que era previsto. Não é reconhecido, no entanto, nenhuma diferença significativa de um local para outro (Tabela 29). Valores superiores a 9, nitidamente maiores que o encontrado nos pontos de coleta em geral, são referentes ao poço tubular e ao coletor de esgoto, este último drenando a água proveniente deste poço, já tratada e usada. 
Tabela 28 : Valores de medidas de condutividade elétrica (200us)

\begin{tabular}{|c|c|c|c|c|c|c|c|c|c|c|c|c|c|}
\hline \multirow[b]{2}{*}{ DATA } & \multirow{2}{*}{\multicolumn{2}{|c|}{$\mathrm{CHU}$ VA }} & \multirow[b]{2}{*}{ PM01 } & \multicolumn{2}{|c|}{ PROCEDÊNCIA } & \multirow{2}{*}{$\begin{array}{l}\text { DAS } \\
\text { PM04 }\end{array}$} & \multicolumn{2}{|c|}{ AMOSTRAS } & \multirow[b]{2}{*}{ PM07 } & \multirow[b]{2}{*}{$\begin{array}{c}\text { CACIM- } \\
\text { BA } \\
\text { C2 } \\
\end{array}$} & \multirow[b]{2}{*}{$\begin{array}{c}\text { POÇO } \\
\text { TUBU- } \\
\text { LAR }\end{array}$} & \multirow[b]{2}{*}{\begin{tabular}{|c|} 
SUR- \\
GÊNCIA
\end{tabular}} & \multirow[b]{2}{*}{$\begin{array}{c}\text { ESGO- } \\
\text { TO }\end{array}$} \\
\hline & & & & PM02 & PḾ03 & & PM05 & PM06 & & & & & \\
\hline $30 / 10 / 96$ & & & & & & & & & & & & & \\
\hline $08 /(04 / 97$ & & & 73,5 & 85,3 & 102,2 & 71,9 & 84,6 & & & & & & \\
\hline $30 / 4 / 97$ & & & & & & & & & & & & & 330 \\
\hline $7 / 5 / 97$ & & & & & & & & & & & 163,1 & & 307,0 \\
\hline $23 / 5 / 97$ & & 63,3 & 72,6 & 74,2 & 62,4 & 84,3 & 74,1 & & & 100,2 & & & \\
\hline $3 / 6 / 97$ & & 33,7 & & & & & & & & & & & \\
\hline $1 / 7 / 97$ & & & & & & & & & & & 170,1 & & \\
\hline $8 / 7 / 097$ & & & 72,2 & 83,1 & 56,5 & 66,0 & 93,7 & & & 98,1 & & & \\
\hline $20 / 8 / 97$ & & & 68,7 & 69,9 & 60,1 & 65,6 & 85,1 & & & 120,8 & & & \\
\hline $4 / 9 / 97$ & & & & & & & & & & & 142,2 & & \\
\hline $24 / 9 / 97$ & & & 80,3 & 74,3 & 63,9 & 72,6 & 64,3 & & & 167,3 & & & \\
\hline $26 / 10 / 97$ & 4,45 & 24,1 & & & & & & & & & & & \\
\hline $4 / 11 / 97$ & & & & & & & & & & & 133,4 & & \\
\hline $12 / 11 / 97$ & 12,7 & 47,0 & 32,8 & 58,6 & 40,1 & 41,2 & 35,4 & & & 128,1 & & & 210,1 \\
\hline $7 / 4 / 98$ & 6,3 & 10,6 & & & & & & & & & & & \\
\hline $16 / 4 / 98$ & & & 70,7 & 73,4 & 57,7 & 64,1 & 56,2 & 31,9 & 42,1 & 225,0 & 160,0 & & \\
\hline $3 / 6 / 98$ & & & & 81,5 & & 39,7 & 52,0 & 23,5 & 24,5 & & 98,00 & 60,4 & \\
\hline & & & & & & 210,1 & & MAIS & ALTO & QUE & MÉDIA & & \\
\hline
\end{tabular}


Tabela 29: Resultados de determinação do $\mathrm{Ph}$ in loco

\begin{tabular}{|c|c|c|c|c|c|c|c|c|c|c|c|c|c|}
\hline & $\mathrm{P}$ & $\mathrm{R} \quad \mathrm{O}$ & $\mathrm{C} \quad \mathrm{E}$ & D $\hat{E}$ & $\mathrm{~N} \quad \mathrm{C}$ & $1 \mathrm{~A}$ & D & A S & A & $\mathrm{M} \mathrm{O}$ & $\begin{array}{lll}\mathrm{S} & \mathrm{T} \\
\mathrm{N}\end{array}$ & A $S$ & \\
\hline DATA & $\begin{array}{l}\mathrm{CHU} \\
\mathrm{A} \\
\end{array}$ & $\begin{array}{r}\mathrm{VA} \\
\mathrm{B} \\
\end{array}$ & PM01 & PM02 & PM03 & PM04 & PM05 & PM06 & PM07 & $\begin{array}{c}\text { CACIM- } \\
\text { BA } \\
\text { C2 }\end{array}$ & $\begin{array}{c}\text { POCO } \\
\text { TUBU- } \\
\text { LAR } \\
\end{array}$ & $\begin{array}{c}\text { SURGEN- } \\
\text { CIA }\end{array}$ & $\begin{array}{c}\text { ESGO- } \\
\text { TO }\end{array}$ \\
\hline $30 / 10 / 96$ & & & 6,07 & & 6,31 & 6,46 & 6,50 & & & & & & \\
\hline $8 / 4 / 97$ & & & 5,71 & 5,82 & 6,00 & 5,70 & 5,43 & & & & & & \\
\hline $30 / 4 / 97$ & & & & & & & & & & & & & 8,78 \\
\hline $7 / 5 / 97$ & & & & & & & & & & & 9,37 & & 9,05 \\
\hline $23 / 5 / 97$ & & 7,47 & 5.69 & 5,82 & 5,67 & 6,06 & 5,50 & & & 6,44 & & & \\
\hline $3 / 6 / 97$ & & 6,81 & & & & & & & & & & & \\
\hline $1 / 7 / 97$ & & & & & & & & & & & 9,42 & & \\
\hline $8 / 7 / 97$ & & & 5,89 & 5,96 & 5,73 & 5,93 & 5,40 & & & 6,74 & & & \\
\hline $20 / 8 / 97$ & & & 5,49 & 5,53 & 5,49 & 5,55 & 5,22 & & & 6,31 & & & \\
\hline $4 / 9 / 97$ & & & & & & & & & & & 9,28 & & \\
\hline $24 / 9 / 97$ & & & 5,58 & 5,51 & 5,43 & 5,68 & 5,32 & & & 6,33 & & & \\
\hline $26 / 10 / 97$ & 6,48 & 6,55 & & & & & & & & & & & \\
\hline $4 / 11 / 97$ & & & & & & & & & & & 950 & & \\
\hline $12 / 11 / 97$ & 5,85 & 6,96 & 5,67 & 5,62 & 5,48 & 5,52 & 5,42 & & & 6,24 & & & 9,11 \\
\hline $7 / 4 / 98$ & 6,91 & 6,90 & & & & & & & & & & & \\
\hline $16 / 4 / 98$ & & & 5,85 & 5,89 & 5,67 & 5,71 & 5,17 & 5,04 & 5,10 & 6,26 & 955 & & \\
\hline $3 / 6 / 98$ & & & & 6,32 & & 5,94 & 5,81 & 5,54 & 5,59 & & 9,11 & 7,08 & \\
\hline
\end{tabular}

$$
8,70
$$


Tabela 30 : Resultados de análise quimica da água - $\mathrm{CO}_{3}{ }^{2}$ e $\mathrm{HCO}_{3}$

\begin{tabular}{|c|c|c|c|c|c|c|c|c|c|c|c|}
\hline \multirow{3}{*}{ DATA } & \multicolumn{5}{|c|}{$\begin{array}{lllllllllll}\mathrm{P} & \mathrm{R} & \mathrm{O} & \mathrm{C} & \mathrm{E} & \mathrm{D} & \mathrm{E} & \mathrm{N} & \mathrm{C} & \mathrm{I} & \mathrm{A} \\
\end{array}$} & \multicolumn{2}{|l|}{ D A S } & \multicolumn{4}{|c|}{ A $\quad$ M $\quad$ O } \\
\hline & PM01 & PM02 & PM03 & PM04 & PM05 & PM06 & PM07 & $\begin{array}{c}\text { CACIM- } \\
\text { BA } \\
\text { C2 } \\
\end{array}$ & $\begin{array}{c}\text { SUR- } \\
\text { GÊNCIA }\end{array}$ & $\begin{array}{r}\mathbf{P O} \\
\mathrm{T} \mathrm{BU} \\
\end{array}$ & $\mathbf{A} \mathbf{R}$ \\
\hline & & & & $\mathrm{HCO}_{3}^{-}$ & $(\mathrm{mg} / \mathrm{L})$ & & & & & $\begin{array}{c}\mathrm{HCO}_{3}^{-} \\
(\mathrm{mg} / \mathrm{L})\end{array}$ & $\begin{array}{l}\mathrm{CO}_{3}{ }^{2-} \\
(\mathrm{mg} / \mathrm{L})\end{array}$ \\
\hline $\begin{array}{c}23 / 3 / 97 \mathrm{~A} \\
12 / 4 / 98\end{array}$ & $\mathrm{~V} A$ & $\mathrm{ZA}$ & $\mathrm{M} \quad \mathrm{E}$ & $\mathrm{NT}$ & $\mathrm{O}$ & $\mathrm{DE}$ & $\mathrm{ES}$ & $\mathrm{GO}$ & TO & & \\
\hline $16 / 4 / 98$ & 27,00 & 46,12 & 31,44 & 38,30 & 25,92 & 25,92 & 17,96 & 48.00 & & 33,75 & 67,50 \\
\hline $3 / 6 / 98$ & & 48,88 & & 35,36 & 27,04 & 27,04 & 21,84 & & 44,72 & 37,00 & 60,72 \\
\hline
\end{tabular}


Valores maiores que 8 de pH são uma das características da água explotada dos Aqüíferos Adamantinas e Santo Anastácio, em vários poços tubulares no Municipio de Presidente Prudente e municipios vizinhos (GODOY, 1997). Problemas de incrustações são constatados também nestes poços. Do ponto de vista hidrogeoquímico, estas águas são bicarbonatadas cálcicas a carbonatadas cálcicas.

No caso do poço tubular da UNESP, a água é bicarbonatada e carbonatada sódica (vide Tabelas 30 e 34), o que discorda do que é próprio das águas de poços tubulares do aqüifero Adamantina (CAMPOS, 1987 - Anexos) .

B - Resultados referentes a possíveis contaminantes

Com base nos resultados disponiveis de análise química e na quantidade calculada de água residuária introduzida no solo, avalia-se a possibilidade de monitorar alguns elementos, principalmente aqueles considerados como os mais móveis. Os cálculos referentes a esta avaliação estão resumidos na Tabela 31 .

Tabela 31: Estimativa da quantidade de $\mathrm{NO}_{3}, \mathrm{Cl}$ e $\mathrm{Na}^{+}$introduzidos no solo pelo vazamento do coletor de água residuária

\begin{tabular}{|c|c|c|c|c|c|c|}
\hline $\begin{array}{l}\text { ELEMENTO } \\
\text { OU ION }\end{array}$ & $\mathbf{N}$ & $\mathrm{Na}^{+}$ & $\mathrm{Cl}^{-}$ & $F$ & $\mathrm{SO}_{4}^{2-}$ & $\begin{array}{c}\text { LABORA- } \\
\text { TORHO } \\
\text { RESPONSAVEL }\end{array}$ \\
\hline $\mathrm{Mg} / \mathrm{L}$ & 51,7 & & & & & SABESP \\
\hline $\begin{array}{c}\mathrm{Mg} / \mathrm{L} \\
\text { (MÉDIA) }\end{array}$ & & 66,83 & 21,32 & 1,49 & 8,31 & $\begin{array}{c}\mathrm{CAS} / \mathrm{IG} / \mathrm{U} \\
\mathrm{SP}\end{array}$ \\
\hline $\begin{array}{l}\text { em 156.000L } \\
\text { (ACIDENTE 1) }\end{array}$ & $8,06 \mathrm{~kg}$ & $10,42 \mathrm{~kg}$ & $3,32 \mathrm{~kg}$ & $0,23 \mathrm{~kg}$ & $1,29 \mathrm{~kg}$ & \\
\hline $\begin{array}{l}\text { em 126.000L } \\
\text { (ACIDENTE 2) }\end{array}$ & $6,51 \mathrm{~kg}$ & $8,42 \mathrm{~kg}$ & $2,68 \mathrm{~kg}$ & $0,19 \mathrm{~kg}$ & $1,00 \mathrm{~kg}$ & \\
\hline
\end{tabular}


Estas quantidades estimadas dos elementos foram sendo adicionadas à água subterrânea, somando-se ao que esta já continha dos elementos considerados.

Quanto às condições para a seu transporte até a zona saturada, deve ser primeiramente destacada a pluviosidade, pouco concentrada, no período do primeiro evento de vazamento e nos seguintes 41 dias, até o final de maio, somando $86,7 \mathrm{~mm}$, assim como a pluviosidade registrada no més junho, com um total de $238,7 \mathrm{~mm}$ e concentrada em períodos curtos. Após esse período de pluviosidade intensificada, a condição de drenagem através do solo tornou-se muito favorável, como indicam os dados dos tensiômetros.

$\mathrm{C}$ - Resultados Referentes a $\mathrm{NO}_{3}^{-}$

Os resultados distinguem a cacimba $\mathrm{C} 2$ como o local onde o teor elevado de $\mathrm{NO}_{3}$ apareceu com mais freqüência (Tabela 32), sendo esta distinção ressaltada nos testes estatísticos. A particularidade que diferencia este local de amostragem dos demais é a existência de restos de raízes em putrefação na água encontrada na cacimba. Deduz-se que o nitrato provém de ação intensa de bactérias sobre estes detritos.

Os valores mais baixos de teor, destacados na análise estatística, são encontrados em amostras dos poços PM05, PM06, PM07 e na surgência amostrada. O terreno onde se localizam estes poços e a surgência diferencia-se do terreno localizado a montante, principalmente do que é identificado com a área do pomar, pelo tipo de cobertura vegetal e por apresentarem hidromorfismo no solo. A Foto 16 mostra o perfil de solo e parte do substrato rochoso e a concentração de umidade neles. As condições redutoras em determinados níveis deste solo atuam desfavoravelmente à formação do nitrato. 
Tabela 32: Resultado de análise química de água $-\mathrm{NO}_{3}$

\begin{tabular}{|c|c|c|c|c|c|c|c|c|c|c|c|c|c|}
\hline DATA & $\begin{array}{l}\mathrm{CHU} \\
\mathrm{A}\end{array}$ & $\begin{array}{l}\mathrm{VA} \\
\mathrm{B}\end{array}$ & PROCE & PM02 & $\begin{array}{c}\text { DAS } \\
\text { PM03 }\end{array}$ & PM04 & PM05 & PM06 & PM07 & $\begin{array}{c}\text { CACIM- } \\
\mathrm{BA} \\
\mathrm{C} 2\end{array}$ & $\begin{array}{c}\text { POÇO } \\
\text { TUBU- } \\
\text { LAR }\end{array}$ & $\begin{array}{c}\text { SUR- } \\
\text { GÊNCIA }\end{array}$ & $\begin{array}{c}\text { ESGO- } \\
\text { TO }\end{array}$ \\
\hline $30 / 10 / 96$ & & & 6,56 & 8,50 & 8,50 & 8,50 & 12,19 & & & & & & \\
\hline $08 / 04 / 97$ & & & 7,56 & 6,80 & 7,96 & $8 ; 21$ & 0,49 & & & & & & \\
\hline $24 / 44915 / 97$ & & $\mathrm{VA}$ & $\mathrm{Z} \quad \mathrm{A}$ & $\mathrm{ME}$ & $\mathrm{NT}$ & $\mathrm{O}$ & & D E & & E S & $\mathrm{GO}$ & $\mathrm{T} \mathrm{O}$ & \\
\hline $30 / 4 / 97$ & & & & & & & & & & & & & 3,05 \\
\hline $7 / 5 / 97$ & & & & & & & & & & & 3,27 & & 4,85 \\
\hline $16 / 5 / 97$ & VAZA & MEN & TO & $\overline{D E}$ & $\widehat{A G U A}$ & CLORA & $\overline{\mathrm{DA}} \mathrm{E}$ & FLUORE & TADA & PRÓXIM & O A & $\mathrm{C} 2$ & \\
\hline $23 / 5 / 97$ & & 0,77 & 6,80 & 6,84 & 4,09 & 5,53 & 0,37 & & & 0,81 & & & \\
\hline $3 / 6 / 97$ & & 0,90 & & & & & & & & & & & \\
\hline $1 / 7 / 97$ & & & & & & & & & & & 3,59 & & \\
\hline $8 / 7 / 97$ & & & 6,36 & 8,32 & 2,99 & 3,59 & 0,43 & & & 0,51 & & & \\
\hline $20 / 8 / 97$ & & & 5,93 & 7,77 & 3,28 & 4,03 & 0,68 & & & 5,45 & & & \\
\hline $4 / 9 / 97$ & & & & & & & & & & & 3,72 & & \\
\hline $24 / 9 / 97$ & & & 6,85 & 7,14 & 3,19 & 3,63 & 0,55 & & & 25,87 & & & \\
\hline $15 / 10 / 97$ & & 1,72 & & & & & & & & & & & \\
\hline $26 / 10 / 97$ & 0,41 & 1,20 & & & & & & & & & & & \\
\hline $4 / 11 / 97$ & & & & & & & & & & & 2,25 & & \\
\hline $12 / 11 / 97$ & 0,18 & 0,14 & 6,70 & 7,79 & 3,63 & 4,95 & 0,50 & & 0,50 & 55,90 & & & 2,28 \\
\hline $07 / 4 / 98$ & 6,3 & 10,6 & & & & & & & & & & & \\
\hline $\begin{array}{l}23 / 31- \\
12 / 4 / 98\end{array}$ & & $\mathrm{VA}$ & $\mathrm{ZA}$ & $M E$ & $\mathrm{~N} T$ & $\mathrm{O}$ & & $\mathrm{DE}$ & & $\mathrm{ES}$ & $\mathrm{GO}$ & T O & \\
\hline $16 / 4 / 98$ & & & 5,51 & 5,27 & 4,25 & 4,79 & 0,11 & 0,16 & 0,92 & 64,80 & 2,89 & & \\
\hline $03 / 6 / 98$ & & & & 32,71 & & 5,25 & 0,25 & 0,19 & 1,18 & & 3,66 & 0,05 & \\
\hline
\end{tabular}

55,90 > MÉDIA 
Tabela 33 : Resultados de análise química da água - $\mathrm{Cl}(\mathrm{mg} / \mathrm{L})$

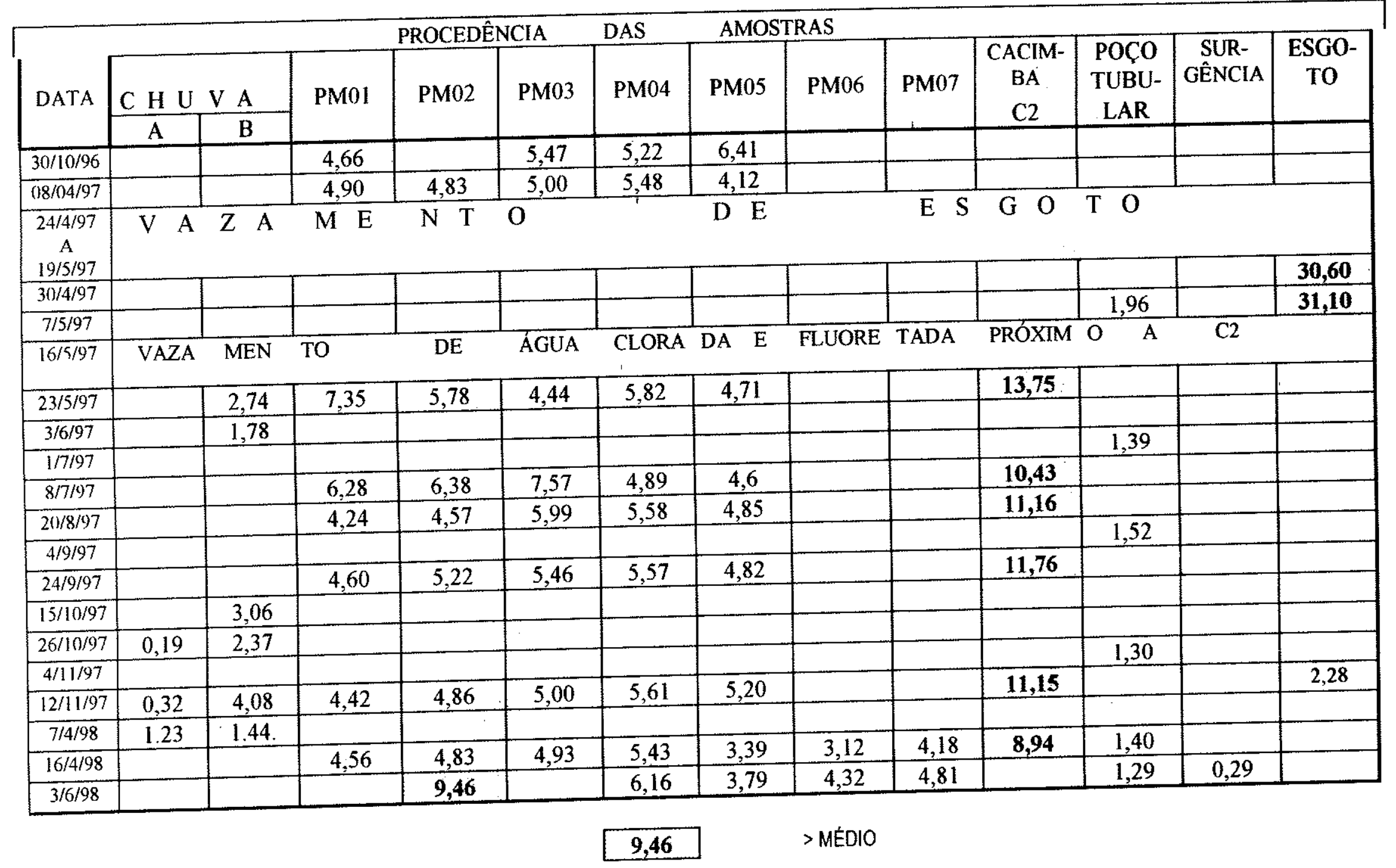


Tabela 34: Resultados de análise química da água - $\mathrm{Na}^{+}(\mathrm{mg} / \mathrm{L})$

\begin{tabular}{|c|c|c|c|c|c|c|c|c|c|c|c|c|c|}
\hline & & & & PROCEDÊ & ICIA & DAS & AMOS & RAS & & & & & \\
\hline DATA & $\begin{array}{l}\mathrm{CHU} \\
\mathrm{A}\end{array}$ & $\begin{array}{l}\mathrm{VA} \\
\mathrm{B} \\
\end{array}$ & PM01 & PM02 & PM03 & PM04 & PM05 & PM06 & PM07 & $\begin{array}{c}\text { CACIM- } \\
\text { BA } \\
\text { C2 }\end{array}$ & $\begin{array}{c}\text { POÇO } \\
\text { TUBU- } \\
\text { LAR }\end{array}$ & 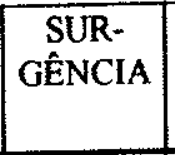 & $\begin{array}{c}\text { ESGO- } \\
\text { TO }\end{array}$ \\
\hline $30 / 10 / 96$ & & & 4,30 & & 5,30 & 8,60 & 9,20 & & & & & & \\
\hline $08 / 04 / 97$ & & & 5,20 & 5,50 & 4,40 & 5,40 & 4,50 & & & & & & \\
\hline $\begin{array}{c}24 / 4 / 97 \\
A \\
19 / 5 / 97 \\
\end{array}$ & $\mathrm{VA}$ & $Z A$ & $\mathrm{ME}$ & $\mathrm{N} \mathrm{T}$ & $\mathrm{O}$ & & $\mathrm{DE}$ & & $\mathrm{E} S$ & $\mathrm{GO}$ & $\mathrm{T} \mathrm{O}$ & & \\
\hline $30 / 4 / 97$ & & & & & & & & & & & & & 67,50 \\
\hline $7 / 5 / 97$ & & & & & & & & & & & 44,00 & & 76,00 \\
\hline $16 / 5 / 97$ & VAZA & MEN & TO & $\overline{\mathrm{DE}}$ & ÁGUA & CLORA & $\mathrm{DA} \quad \mathrm{E}$ & FLUORE & TADA & PRÓXIM & O A & $\overline{\mathrm{C} 2}$ & \\
\hline $22 / 5 / 97$ & & 3,40 & 6,10 & 5,60 & 4,40 & 5,00 & 3,10 & & & 9,40 & & & \\
\hline $3 / 6 / 97$ & & 0,70 & & & & & & & & & & & \\
\hline $1 / 7 / 97$ & & & & & & & & & & & 40,00 & & \\
\hline $8 / 7 / 97$ & & & 4,60 & 6,80 & 6,10 & 5,10 & 3,90 & & & 8,20 & & & \\
\hline $20 / 8 / 97$ & & & 4,30 & 4,50 & 3,50 & 3,70 & 2,90 & & & 3,80 & & & \\
\hline $4 / 9 / 97$ & & & & & & & & & & & 4,30 & & \\
\hline $24 / 9 / 97$ & & & 2,70 & 3,60 & 2,30 & 4,50 & 4,80 & & & 4,50 & & & \\
\hline $15 / 10 / 97$ & & 0,70 & & & & & & & & & & & \\
\hline $26 / 10 / 97$ & 0,60 & 1,20 & & & & & & & & & & & \\
\hline $4 / 11 / 97$ & & & & & & & & & & & 48,00 & & \\
\hline $12 / 11 / 97$ & 1,60 & 0,90 & 5,00 & 5,10 & 3,70 & 4,20 & 2,60 & & & 12,00 & & & 57,00 \\
\hline $\begin{array}{c}23 / 3 / 97 \\
A \\
12 / 4 / 98\end{array}$ & $\mathrm{VA}$ & $\mathrm{ZA}$ & $\mathrm{ME}$ & $\mathrm{N} T$ & $\mathrm{O}$ & & $\mathrm{DE}$ & & E S & $\mathrm{GO}$ & $\mathrm{TO}$ & & \\
\hline $7 / 4 / 98$ & 1,70 & 0,90 & & & & & & & & & & & \\
\hline $16 / 4 / 98$ & & & 5,10 & 4,70 & 4,50 & 5,10 & 2,70 & 3,00 & 2,00 & 8,50 & 49,00 & & \\
\hline $3 / 6 / 98$ & & & & $\mathbf{8 , 8 0}$ & & 4,70 & 2,90 & 4,60 & 1,30 & & 44,00 & 2,5 & \\
\hline
\end{tabular}

49,90 > MÉDIO 
D - Resultados Referentes a $\mathrm{Cl}^{-}$

$\mathrm{O} \mathrm{Cl}$ está presente no esgoto domiciliar como $\mathrm{Cl}^{\prime}$ e como residual. Nesta última forma, dificilmente ele é identificado em análises químicas. $\mathrm{O} \mathrm{Cl}$ contido na água residuária provém dos compostos utilizados no tratamento da água. Está presente nas formas de ácido hipocloroso ou do ín hipoclorito ou na forma de cloraminas, no primeiro caso sendo classificado como "cloro residual livre" e no segundo caso, como "cloro residual combinado" (METCALF \& EDDY, 1979).

$\mathrm{O} \mathrm{Cl}^{-}$deriva essencialmente da urina, onde é expelido em uma quantidade aproximada de $6 \mathrm{~g}$ por pessoa. No esgoto doméstico, a sua concentração é superior a $15 \mathrm{mg} / \mathrm{L}$.

A análise estatística destaca a água da cacimba C2 pelo seu maior conteúdo de $\mathrm{Cl}^{-}$, assim também como de $\mathrm{Na}^{2}$, em comparação com a dos outros pontos de amostragem. Não se correlaciona esta diferença a nenhum tipo de distinção de condições de uso ou de ambiente em relação aos demais pontos de amostragem. $O$ único fator possivel de distinção deste local é o evento de vazamento, nas suas proximidades, a 16/05/97, da uma adutora de abastecimento de água para o Campus. Os valores relativamente altos destes íons já são manifestados a 22/05/97. Tendo sido observada a infiltração de água pela sua parede, através de frestas no revestimento de tijolos, é admitida a hipótese de que esta parede tenha atuado como um atalho na comunicação com o aqüifero livre da água derramada no vazamento.

E - A Utilização dos íons $\mathrm{Cl}^{-}, \mathrm{Na}^{+}$e $\mathrm{NO}_{3}^{-}$na análise da recarga do aqüifero Livre

Outro vator elevado de teor é revelado em amostra do poço PM02 coletada a

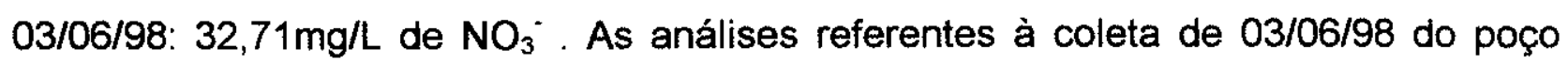
PM02 registram aumento expressivo de no teor de $\mathrm{NO}_{3}{ }^{-}, \mathrm{Cl}^{*}$, aumento distinto de $\mathrm{Na}^{+}$e aumento discreto de $\mathrm{pH}$ (Figura 34). 
Tabela 35: Variação dos teores- $\mathrm{Na}+\mathrm{Cl}-\quad$, F- e NO3- Poço PM02

\begin{tabular}{|c|c|c|c|c|}
\hline DATA & $\begin{array}{c}\mathrm{Na}^{+} \\
(\mathrm{Mg} / \mathrm{L})\end{array}$ & $\begin{array}{c}\mathrm{Cl}^{-} \\
(\mathrm{Mg} / \mathrm{L})\end{array}$ & $\begin{array}{c}\mathrm{F}^{-} \\
(\mathrm{Mg} / \mathrm{L})\end{array}$ & $\begin{array}{c}\mathrm{NO}_{3}{ }^{-} \\
(\mathrm{Mg} / \mathrm{L})\end{array}$ \\
\hline $08 / 04 / 97$ & 5,50 & 4,83 & 0,13 & 6,80 \\
\hline $22 / 05 / 97$ & 5,60 & 5,78 & 0,59 & 6,84 \\
\hline $08 / 07 / 97$ & 6,80 & 6,38 & 0,09 & 8,32 \\
\hline $20 / 08 / 97$ & 4,50 & 4,57 & 0,01 & 7,77 \\
\hline $24 / 09 / 97$ & 3,60 & 5,22 & 0,07 & 7,14 \\
\hline $12 / 11 / 97$ & 5,10 & 4,86 & 0,14 & 7,79 \\
\hline $16 / 04 / 98$ & 4,70 & 4,83 & 0,01 & 5,27 \\
\hline $03 / 06 / 98$ & 8,80 & 9,46 & 0,11 & 32,71 \\
\hline
\end{tabular}

valor bem mais alto do que o médio

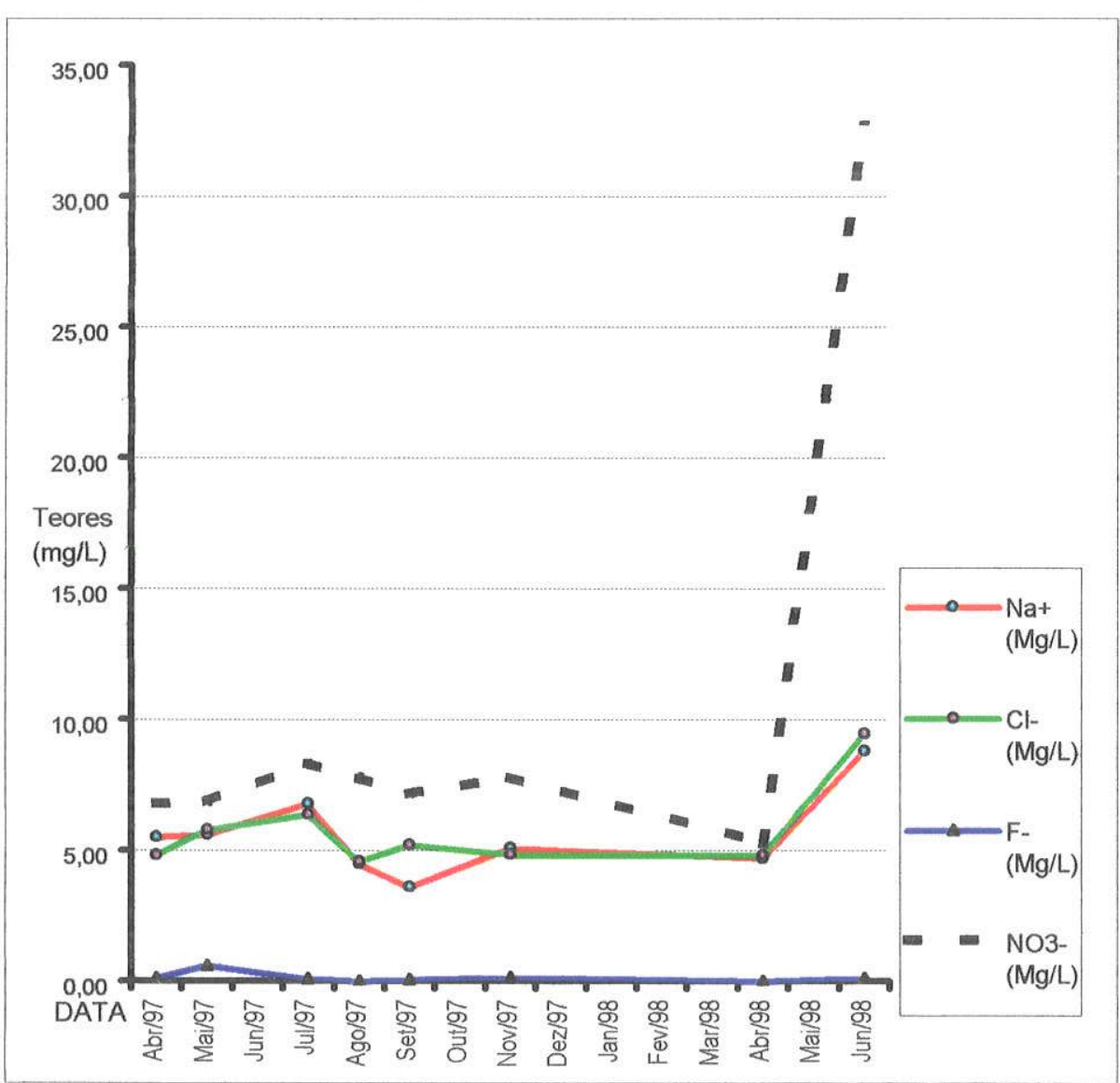

Figura 34: Variação dos teores de $\quad \mathrm{Na}+, \mathrm{Cl}$-, F- e NO3- - Poço PM02 
Os íons $\mathrm{Na}^{+}$e $\mathrm{Cl}^{-}$podem ser empregados ser empregados como traçadores químicos (POLI, 1992). Para o sua aplicação efetiva, há necessidade de introduzir $\mathrm{NaCl}$ ou outro sal de qualquer um dos dois elementos em quantidade relativamente elevada, com a desvantagem de elevar a densidade da solução portadora do sal.

Em estudos de contaminação de água subterrânea por dejetos humanos em Botswana na África, é demonstrada a utilidade como traçador químico do $\mathrm{Cl}^{-}$introduzido na própria contaminaçăo (LANGERSTEDT, SACKS \& SEFE, 1996).

No Canadá, foram usados o $\mathrm{Na}^{+}$e $\mathrm{Br}^{-}$como traçadores em estudo de caso de contaminação, através de tanque séptico drenado por sistema de tubos furados (ROBERTSON et al ,1989). Trata-se no caso de um sistema séptico de uma única residência. $\mathrm{O}$ composto $\mathrm{NaBr}$ foi injetado instantaneamente no tanque em quantidade de $1 \mathrm{~kg}$. No monitoramento da contaminação, a condutividade elétrica também serviu como traçador.

No caso do poço PM02, deve ser considerada a possibilidade de que a o incremento conjunto do teor dos 3 ions se constitua numa resposta, em intervalo de tempo de 13 meses e 3 semanas, aos eventos de vazamento de esgoto,. Trata-se de um intervalo relativamente curto para a resposta, mas admissivel, levando-se em conta a existência, na zona não saturada, de fluxo preferencial, da fuga de água por cavidades de raízes mortas e da atuação do fraturamento da rocha. Estes fatores já foram mencionados na discussão referente à correlação entre os variações na pluviosidade e a oscilação do nivel freático (item 5.4.2, pg. 105).

F - Resultados referentes aos teores de $\mathrm{Na}^{+}$na água do poço tubular

Teores de $\mathrm{Na}^{+}$comparáveis aos determinados em amostras do poço tubular da FCT/UNESP são muito raros nos aqüiferos Bauru, conforme se confere nos registros disponiveis (CAMPOS, 1987 - ANEXOS).

Em zonas continentais distantes da costa, o $\mathrm{Na}$ pode ser encontrado em quantidades relativamente altas em regiōes de clima árido (HEM, 1985). Fora destas condições climáticas, é rara esta ocorrência de teores elevados. Altas concentrações 
de $\mathrm{Na}^{+}$antropogênico na água subterrânea são registradas em Salt Lake Valley, em área de intensa irrigação. Deve-se entender como teor elevado de $\mathrm{Na}^{+}$o que ultrapassa o valor de 500 ppm, portanto muito acima daquele relacionados ao poço tubular do Campus da FCT/UNESP de Presidente Prudente.

Casos de teores de $\mathrm{Na}^{+}$de origem natural acima de 500 ppm não são raros em aqüiferos onde se encontram evaporitos ou outros aqüiferos explotados em zonas petrolíferas, (MATHESS, 1982 ). No entanto, não deve causar surpresa a ocorrência de anomalia de $\mathrm{Na}$ em resistatos como arenitos, devido à a existência de resíduos cristalinos de soluções retidas nos poros ou a presença de sais de sódio no cimento.

Duas observações são necessárias quanto a anomalias de $\mathrm{Na}^{+}$:

- pouca atenção é dedicada à sua ocorrência, porque as normas quanto ao uso e de água são muito pouco restritivas à presença deste íon;

- a grande maioria das anomalias é antropogênica.

Uma das fontes hipotéticas de $\mathrm{Na}$ em teor relativamente elevado, que é encontrado nas amostras do poço tubular é o lixo domiciliar. No chorume, verifica-se a sua presença em teores elevados (QASIM \& CHIANG, 1994). No entanto, é acompanhado por outros íns, principalmente o $\mathrm{NO}_{3}{ }^{\circ}$ e $\mathrm{SO}_{4}{ }^{2-}$, cuja migração na água subterrânea, em teores relativamente elevados, se dá paralelamente à sua. Pelas análises químicas referentes ao poço tubular, esta forma de associação não é identificada.

No entanto, a hipótese segundo a qual este resultado anômalo de $\mathrm{Na}^{+}$seja antropogênico não deve ser descartada. 
$\mathrm{G}-\mathrm{SO}_{4}{ }^{2-}$ - Interpretações referentes ao rejeito de laboratório

As análises estatísticas destacam as amostras do poço PM05 como diferentes das amostras coletadas em outros locais pelo maior conteúdo de $\mathrm{SO}_{4}{ }^{2-}$ dissolvido.

O sulfato é por si um íon complexo, mas caracteriza-se por acentuada tendência a formar espécies mais complexas (HEM, 1985 ). Por fator de afinidade, predominam as associações de $\mathrm{SO}_{4}{ }^{2-} \mathrm{com} \mathrm{Na}^{+} \mathrm{e} \mathrm{Ca}^{2+}$, proporcionalmente crescentes com o aumento no teor de $\mathrm{SO}_{4}{ }^{2-}$. A redução do sulfato na água é muito rara, porque depende da ação, em condições anaeróbicas, de determinada espécie de bactéria.

Quanto às reaçōes mais prováveis entre as substâncias do rejeito de análise química de solo, em meio aquoso, podem ser resumidas, de acordo com VOGEL ( 1982 ), na seqüência apresentada abaixo.

A reação ácido/base da cal com o ácido sulfúrico é simplificada como:

$$
\mathrm{Ca}(\mathrm{OH})_{2}+\mathrm{H}_{2} \mathrm{SO}_{4}-\cdots \mathrm{CaSO}_{4}+2 \mathrm{H}_{2} \mathrm{O}
$$

O $\mathrm{CaSO}_{4}$, cuja solubilidade em água é 0,2/100 (MERCK, 1982 ), (MERCK, 1982), é dissolvido, dando, portanto, $\mathrm{Ca}^{2+} \mathrm{e} \mathrm{SO}_{4}{ }^{2-}$.

Tendo sido empregados $20 \mathrm{ml}$ de $\mathrm{H}_{2} \mathrm{SO}_{4}$ concentrado ( $980 \mathrm{~g} / \mathrm{L}$ ) para cada uma das 3.000 amostras, calcula-se que $19,8 \mathrm{~g}$ deste ácido foram usadas para cada unidade da amostragem. Portanto, o rejeito corresponde ao emprego de cerca de $58 \mathrm{~kg}$ de $\mathrm{H}_{2} \mathrm{SO}_{4}$ puro. Em caso de excesso de $\mathrm{H}_{2} \mathrm{SO}_{4}$, prevalecendo condição de $\mathrm{pH}<4$ e havendo a presença de $\mathrm{Al}$ adsorvido em lamelas de argilas, este metal é então liberado. Devido à presença dos sais empregados na análise de solo, outro efeito possível da atuação deste ácido é a formação de $\mathrm{Al}_{2}(\mathrm{SO} 4)_{3}$, que é solúvel.

Destas reações expressas acima, a mais efetiva é aquela que resulta do contato do ácido com a cal virgem, formando $\mathrm{CaSO}_{4}$, logo dissolvido. Encontra-se então uma explicação plausivel para o teor relativamente elevado de ion $\mathrm{SO}_{4}{ }^{2-}$ na água amostrada do poço PM05. 
Tabela 36 : Resultados de análise química da água - $\mathrm{SO}_{4}{ }^{2} \cdot(\mathrm{mg} / \mathrm{L})$

\begin{tabular}{|c|c|c|c|c|c|c|c|c|c|c|c|c|c|}
\hline & & & & PROCEDÊ & NCIA & DAS & AMOS & RAS & & & & & \\
\hline DATA & $\begin{array}{l}\text { CHU } \\
\mathrm{A} \\
\end{array}$ & $\begin{array}{r}\text { VA } \\
\text { B } \\
\end{array}$ & PM01 & PM02 & PM03 & PM04 & PM05 & PM06 & PM07 & $\begin{array}{c}\text { CACIM- } \\
\text { BA } \\
\text { C2 } \\
\end{array}$ & $\begin{array}{c}\text { POÇO } \\
\text { TUBU- } \\
\text { LAR }\end{array}$ & $\begin{array}{c}\text { SUR- } \\
\text { GÊNCIA }\end{array}$ & $\begin{array}{c}\text { ESGO- } \\
\text { TO }\end{array}$ \\
\hline $30 / 10 / 96$ & & & 4,46 & & 4,00 & 0,58 & 11,08 & & & & & & \\
\hline $08 / 04 / 97$ & & & 6,02 & 6,65 & 3,56 & 1,23 & 21,98 & & & & & & \\
\hline $\begin{array}{c}24 / 4 / 97 \\
\mathrm{~A} \\
19 / 5 / 97 \\
\end{array}$ & $\mathrm{VA}$ & $\mathrm{ZA}$ & $\mathrm{M} E$ & $\mathrm{NT}$ & $\mathrm{O}$ & & $\mathrm{DE}$ & & $E S$ & $\mathrm{GO}$ & $\mathrm{T} \mathrm{O}$ & & \\
\hline $30 / 4 / 97$ & & & & & & & & & & & & & 8,63 \\
\hline $7 / 5 / 97$ & & & & & & & & & & & 0,85 &. & 8,02 \\
\hline $16 / 5 / 97$ & VAZA & MEN & TO & $\overline{\mathrm{DE}}$ & ÁGUA & CLORA & $\mathrm{DA} \quad \mathrm{E}$ & FLUORE & TADA & PRÓXIM & $\mathrm{O} \quad \mathrm{A}$ & $\mathrm{C} 2$ & \\
\hline $22 / 5 / 97$ & & 2,52 & 7,48 & 7,37 & 4,05 & 1,46 & 18,49 & & & 1,19 & & & \\
\hline $3 / 6 / 97$ & & 2,12 & & & & & & & & & & & \\
\hline $1 / 7 / 97$ & & & & & & & & & & & 0,59 & & \\
\hline $8 / 7 / 97$ & & & 6,96 & 5,07 & 3,74 & 1,08 & 31,28 & & & 0,58 & & & \\
\hline $20 / 8 / 97$ & & & 5,86 & 4,65 & 3,30 & 0,85 & 24,46 & & & 0,74 & & & \\
\hline $4 / 9 / 97$ & & & & & & & & & & & 0,66 & & \\
\hline $24 / 9 / 97$ & & & 7,49 & 4,99 & 3,29 & 0,85 & 11,79 & & & 0,81 & & & \\
\hline $15 / 10 / 97$ & & 4,23 & & & & & & & & & & & \\
\hline $26 / 10 / 97$ & 0,51 & 2,46 & & & & & & & & & & & \\
\hline $4 / 11 / 97$ & & & & & & & & & & & 0,51 & & \\
\hline $12 / 111 / 97$ & 6,03 & 0,57 & 6,45 & 4,91 & 3,28 & 1,52 & 5,09 & & & 0,83 & & & 2,28 \\
\hline $\begin{array}{c}23 / 3 / 97 \\
\text { A } 19 \\
12 / 4 / 98 \\
\end{array}$ & $\mathrm{VA}$ & $\mathrm{ZA}$ & $M E$ & $\mathrm{~N} T$ & $\mathrm{O}$ & & $\mathrm{DE}$ & & $\mathrm{ES}$ & $G O$ & $\mathrm{~T} \mathrm{O}$ & & \\
\hline $7 / 4 / 98$ & 0,48 & 0,58 & & & & & & & & & & & \\
\hline $16 / 4 / 98$ & & & 4,50 & 4,44 & 3,80 & 1,36 & 11,33 & 3,48 & 0,78 & 0,51 & 0,70 & & \\
\hline $3 / 6 / 98$ & & & & 4,22 & & 1,79 & 16,13 & 4,19 & 0,56 & & 0,54 & 2,47 & \\
\hline
\end{tabular}


Quanto ao comportamento do ácido fosfórico, as reações são semelhantes às que ocorrem com o ácido sulfúrico, podendo ser resumidas como:

$$
\begin{aligned}
& 3 \mathrm{Ca}(\mathrm{OH})_{2}+2 \mathrm{H}_{3} \mathrm{PO}_{4} \ldots \ldots \mathrm{Ca}_{3}\left(\mathrm{PO}_{4}\right)_{2}+12 \mathrm{H}_{2} \mathrm{O} \\
& \text { O fosfato de cálcio é insolúvel em água. }
\end{aligned}
$$

Com relação ao íon dicromato, trata-se de poderoso agente oxidante, reduzindo-se ele próprio a $\mathrm{Cr}^{3+}$. Simplificadamente, esta redução ocorre segundo esta reação:

$$
\mathrm{Cr}_{2} \mathrm{O}_{7}^{2-}+14 \mathrm{H}_{3} \mathrm{O}^{+}+6 \mathrm{e}--\rightarrow 2 \mathrm{Cr}^{3+}+21 \mathrm{H}_{2} \mathrm{O}
$$

Em laboratório, o dicromato é usado para mais de uma finalidade na oxidação da matéria orgânica.

O dicromato de potássio, em presença do ácido sulfúrico, atua sobre a matéria orgânica, o que resumidamente pode ser expresso nesta reação:

$$
\mathrm{K}_{2} \mathrm{Cr}_{2} \mathrm{O}_{7}+\mathrm{mo}--\rightarrow \mathrm{Cr}^{3+}+\mathrm{Cr}^{6+}+\mathrm{CO}_{2}+\mathrm{H}_{2} \mathrm{O}
$$

As reações dos ions de cromo em presença da cal podem ser estas:

$$
\begin{aligned}
& \mathrm{Cr}^{3+}+3 \mathrm{OH}^{-} \rightarrow \mathrm{Cr}(\mathrm{OH})_{3} \\
& \mathrm{Cr}^{6+}+6 \mathrm{OH}^{-} \rightarrow \mathrm{Cr}(\mathrm{OH})_{6}
\end{aligned}
$$

A atuação neutralizadora da cal é efetiva na imobilização do cromo, produzindo, como se resume acima, hidróxido deste metal. Os dois tipos de hidróxido são praticamente insolúveis. 
5.6.3.4. Resultados referentes à água da chuva e do açude

Constata-se diferença entre a composição química da água da chuva coletada em zona coberta por vegetação e aquela coletada em local distante de qualquer possivel interceptação. Nestas diferenças, não é identificado nenhum sentido lógico ou indicativo de interferência de algum fator particular.

Nos resultados referentes ao açude, não é reconhecido qualquer indício de sua interferência na água coletada nos poços PM05 e PM06 e junto à surgência.

\subsubsection{Zoneamento Hidrogeoquímico da Área Estudada}

A partir da avaliação dos resultados de análise química, com o apoio da análise estatística, é apontada a influência da ação antrópica nas diferenças de composição química da água subterrânea. Pelo que já foi analisado acima, estas diferenças aparecem nitidamente em alguns locais, como se verifica no poço tubular para o teor de $\mathrm{Na}+$, nos poço de monitoramento $\mathrm{PMO}_{2}$ para $\mathrm{Na}^{+}, \mathrm{NO}_{3}{ }^{-}$e $\mathrm{Cl}^{-}$e no $\mathrm{PM05}$ para $\mathrm{SO}_{4}{ }^{2-}$. Estes dados de análise química reforçam a distinção reconhecida através das informações obtidas sobre a hidrodinâmica. 


\section{CONCLUSÕES}

O estudo realizado através da Estação Piloto não se restringiu ao local de sua instalação, tendo sido irradiado o monitoramento a partir desta estação por alguns hectares de um setor de encosta. Dentro deste estudo assim expandido revelou uma complexidade do ambiente, exigindo a análise e a avaliação conjunta de vários fatores ambientais que influem na hidrodinâmica e na hidrogeoquímica das zonas não saturada e saturada.

De acordo com o enfoque hidroquímico, adotando como traçadores químicos os íons $\mathrm{Na}^{+}, \mathrm{Cl}^{-}$e $\mathrm{NO}_{3}$, introduzidos acidentalmente no solo, na zona saturada é constatada uma resposta rápida a uma contaminação que teve origem a menos de 0,5 m da superfície.

Este fato reforça a caracterização de um comportamento de recarga rápida do aqǘfero, baseada na verificação de um intervalo de curto entre eventos da precipitação e intervalos de estiagem e o seu reflexo na oscilação do nivel do aqüifero livre.

Do ponto de vista geológico e hidrogeológico, é importante considerar que, até a profundidade de $20 \mathrm{~m}$ aproximadamente, os bancos de arenito e lamitos intercalados a eles são caracterizados por fraturamento, sobretudo numa zona próxima à superficie, cujos limite inferior acompanha a declividade da encosta. A influência de estratos ou bancos de rocha relativamente mais compacta no fluxo subterrâneo é uma questão ainda em aberto para investigação e avaliação. Devido à distinção comumente adotada entre "meio poroso" e "meio fraturado", tem sido pouco levado em conta o caráter desta zona do depósito sedimentar, que é de meio poroso-fraturado. Este fato representa um risco de natureza hidrodinâmica para a estabilidade de pequenas represas na Região de Presidente Prudente.

É importante observar que a distinção entre rocha sedimentar sã e rocha sedimentar alterada é muito discutível na prática, o que nesta área estudada resulta em dificuldade de diferenciá-las em corte vertical do terreno.

Deve ser validada a hipótese segundo a qual a presença de fendas associadas ao sistema de fraturamento na rocha é decisiva na hidrodinâmica da zona não saturada, constituindo-se em fator de intensificação do fluxo de água subterrảnea. 
Do ponto de vista pedológico e da Física de Solos, mereceram atenção os aspectos do comportamento dos horizontes $B$ texturais, como barreira à drenagem no perfil do solo, podendo, deste modo, impor o fluxo lateral a esta drenagem. Na análise e avaliação dos resultados do ensaio de infiltração e do comportamento do potencial mátrico a diferentes profundidades, é reforçada a hipótese da atuação destes horizontes como obstáculo temporário ao avanço da frente de molhamento. Quanto ao fluxo lateral, não foi encontrada nenhuma indicação de sua presença.

Do ponto de vista do ecossistema, a atuação de cavidades de raízes mortas é evidenciada no ensaio de infiltração. Trata-se de mais um dado a contribuir para se compreender a hidrodinâmica da zona não saturada, no sentido de ressaltar o papel direto ou indireto da vegetação na infiltração da água no terreno. De acordo com a ampla bibliografia consultada a este respeito, os experimentos concernentes à hidrodinâmica na zona não saturada, principalmente aqueles dirigidos à questão da contaminação das águas subterrâneas, incluem a cobertura vegetal como variável fundamental dos processos estudados. É válido considerar como determinante a influéncia das cavidades de raizes mortas no fluxo de água na zona não saturada, pelo menos na área do pomar, isto é, nos arredores da Estação-Piloto.

Uma das características da área estudada é a heterogeneidade do substrato rochoso, sendo verificado que numa área restrita a um setor de um campus universitário, a variável correspondente à natureza dos solos e das rochas influi na diversificação espacial do terreno, determinando uma compartimentação do ambiente.

Alguns componentes do meio ambiente introduzidos por interferências antrópicas contribuem para torná-lo menos favorável a uma pesquisa de caráter ambiental, como é o caso deste estudo executado em Presidente Prudente. É necessário enfatizar que se trata também, nos exemplos do açude que interfere no sistema hidrológico, do soterramento de uma surgència de água por terraços introduzidos artificialmente na superfície do terreno $e$ da disposição do lixo do laboratório sem a devida proteção, de açōes que alteram o comportamento do meio físico e do ecossistema, estando portanto em desacordo com normas técnicas e com a legislaçăo ambiental vigente no país.

No funcionamento da Estaçăo-Piloto, a diversificação do ponto de vista metodológico e técnico reflete o caráter interdisciplinar da pesquisa que é desenvolvida através dela. Deste modo, a aplicação de um método de pesquisa centralizada em seu 
funcionamento possibilita uma integraçăo de informações de variada natureza, devido à interdependência das investigações da geologia, das ciências do solo, da geoquímica e da bioquímica no estudo da hidrodinâmica e da hidrogeoquímica das zonas não saturada e saturada.

$\mathrm{Na}$ área pesquisada, no tocante à etapa da pesquisa correspondente a investigações preliminares, o conhecimento prévio do estado do meio ambiente era fundamental para garantir um determinado grau de segurança para a execução do projeto de pesquisa. Estava prevista a utilização do método geofísico GPR, que não foi possivel, devido a fatores de custo do serviço. Com a exclusão deste recurso de sondagem na execução da projeto, não houve condição de prevenir o acidente ocorrido com um coletor de esgoto, tendo este fato provocado a mudança no rumo na pesquisa. Assim sendo, conclui-se que qualquer avaliação ambiental ou "auditoria ambiental", sobretudo onde importa o monitoramento hidrogeoquímico, deveria contar com o emprego deste método.

A escolha do local de instalação da Estação-Piloto foi baseada no reconhecimento de condições adequadas do ponto de vista geológico, pedológico, do meio ambiente e da garantia do apoio de laboratórios instalados em suas imediações. No entanto, o desenvolvimento da pesquisa evidenciou algumas condições negativas existentes no local escolhido para a instalação da maioria dos equipamentos, que é um pomar abandonado, onde o solo, no aspecto da sua atuação como meio poroso, apresenta irregularidades significativas, principalmente aquelas devidas a raízes mortas.

O desenvolvimento da pesquisa foi prejudicado também pelo funcionamento insatisfatório dos extratores de cápsula porosa e dos blocos de gesso e pelo fato de ter sido impossibilitado o ensaio de permeabilidade, dadas as condições particulares do terreno, que causaram fuga abundante de água.

No caso específico do emprego dos blocos de gesso Soilmoisture na pesquisa, deve ser considerado que se tratou de uma oportunidade de experimentar a sua aplicaçăo para um estudo hidrogeológico. Deste modo, algumas de suas limitações como recurso de medida do potencial mátrico foram reconhecidas, tais como:

- a limitação na escala de valores do ábaco de conversão de leituras do medidor em unidades de potencial mátrico

- a imprecisão de medidas com a presença de sais dissolvidos na água. 
É inegável a importância da questăo da recarga em qualquer estudo sobre o funcionamento de um aqǘfero subterrâneo e sobre a vulnerabilidade da água subterrânea a qualquer tipo de contaminação. A investigação através de uma Estação-Piloto dispôe dos meios para integrar recursos de investigação de variada natureza, exigidos em pesquisa sobre as condições de recarga de um aqǘfero. Neste aspecto, ela deve ser encarada como a alternativa para os estudos efetuados através de lisímetros e colunas, que têm sido abundantemente divulgados, como se pode reconhecer na numerosa bibliografia referente a pesquisas experimentais que enfocam a hidrodinâmica dos meios porosos e também a aspectos de vulnerabilidade de aqǘferos à contaminação. A margem de operação em espaço, que uma estação de observação ou experimental proporciona, garante um alcance de área e profundidade de investigação no solo e no substrato rochoso que é inacessivel a estes dois outros recursos de observação e experimentação.

Na proposição básica de funcionamento de uma estação experimental ou de observação, são implícitas as vantagens de uma investigação "in situ", em condições mais realistas de campo. No entanto, uma área que conta com uma única estação é sujeita ao risco de não ser representativa de uma região. $O$ alcance de informação de uma pesquisa baseada em uma estação isolada é limitada às características de um determinado ambiente, onde se oferece uma combinação muito particularizada das diversas variáveis que devem ser analisadas. $\mathrm{Na}$ área pesquisada, sendo considerada apenas uma encosta, são diferenciadas pelo menos 5 zonas, onde o comportamento hidrodinámico tanto da zona não saturada como da zona saturada é diferenciado, embora a todas as zonas seja estendida uma característica importante nestes aspectos, que é a da vulnerabilidade do aqǘfero livre à contaminação. Devendo ser considerado que raramente pode ser selecionada uma área livre da interferência antrópica, é válido reconhecer que toda diferenciação natural é passivel de ser aprofundada ou modificada por fatores da ação humana.

Deste modo, seja para fins de mapeamento hidrogeológico ou de área piloto de estudos sobre a contaminação das águas subterrâneas ou para a finalidade de experimentaçăo, os resultados de pesquisa executada em uma única estaçăo são discutiveis. Uma área-piloto deve contar com a operação de 3 ou mais estações, devidamente localizadas, integrando um programa de pesquisa multidisciplinar. $E$ dentro de 
um programa de pesquisa executada através de estaçōes de monitoramento, pode ser incluida a pesquisa que utiliza um método de colunas ou lisímetros, deste modo havendo um meio adequado de comparar os resultados de um e de outro método de pesquisa. 


\section{REFERÊNCIAS BIBLIOGRÁFICAS}

ALEXANDRE, G. A. L. (1995) Contribuição ao Estudo do Comportamento Geoquímico do As, $\mathrm{Cu}, \mathrm{Pb}$ e $\mathrm{Zn}$, originários de pesticidas agrícolas, nas Zonas não saturada $\mathrm{e}$ Saturada em Área Urbana e Agrícola do Município de Louveira(SP). São Paulo, 158p (Tese - Doutorado) - Instituto de Geociências, Universidade de Săo Paulo.

ALLISON, F. E. (1955) The enigma of soil nitrogen balance sheets, Advanced Agronomy, 7: 213-50.

ALMEIDA, F.F.M. (1964) Fundamentos geológicos do relevo paulista. In: Geologia do Estado de São Paulo. Boletim do Instituto Geográfico e Geológico, v. 41, p. 167-263. ALMEIDA, F.F.M.; MELO, M.S. (1981). A Bacia do Paraná e o vulcanismo mesozóico. In: INSTITUTO DE PESQUISAS TECNOLÓGICAS DO ESTADO DE SÃO PAULO IPT Mapa Geológico do Estado de São Paulo, São Paulo, IPT, v.1, p.46-81.

ALMEIDA, M. A.; STEIN, D. P.; MELO, M. S.; BISTRICHI, C.A.;PONÇANO. W.L.; HASUI, Y.; ALMEIDA, F.F.M. (1981) Geologia do Oeste Paulista e áreas fronteiriças dos Estados de Mato Grosso do Sul e Paraná, In: Coletânea de Trabalhos e Debates: Publicação SBG-SP: Publicação Especial, n. 7, p.31-47. I Apresentado a Mesa Redonda A Formação Bauru no Estado de São Paulo e Regiões Adjacentes, São Paulo, 1981.

AMERICAN PUBLIC HEALTH ASSOCIATION; AMERICAN WATER WORKS ASSOCIATION; WATER POLLUTION CONTROL FEDERATION (1982) Métodos Estándar para el examen de Áquas y Áquas de Desecho. México, Editorial Interamericana S. A.. 609 p.

ASSOCIAÇÃO BRASILEIRA DE GEOLOGIA DE ENGENHARIA (1996) Ensaios de permeabilidade em solos - orientações para sua execução no campo. OLIVEIRA, A.M.S.; CORRÉA FILHO, D. (coords.)São Paulo, ABGE, boletim n $n^{\circ}$. 04, $3^{\text {a }}$. ed., 24 p e Anexos.

BISH, D.L. \& DUFFY, C.J. (1990) Thermogravimetric analysis of minerals, in: STUCKI, J. ; BISH \& D. L.; MUMPTON, F. A. (eds) Cms Workshop Lectures, v.3. Thermal analysis in Clay Science, Boulder, Colorado, The Clay Minerals Society, p. 95-189.

BIZELL, J.A. (1944) Lysimeters experiments. VI The effects of croping and fertilization on the losses of nitrogen from the soil, Cornell, USA, Cornell, Agr. Experimental Station Memo. 256, pp 1-14. 
CAMPOS, H. C. N. S. (1987) Contribuição ao Estudo Hidrogeoguímico do Grupo Bauru no Estado de São Paulo. São Paulo, 157p. (Dissertação - Mestrado) - Instituto de Geociências, Universidade de São Paulo.

CARVALHO, W. A.; SUDO, H.; FREIRE, O.; GODOY, M.C.T.F.; TEIXEIRA, S.R.; PANOSO, L. A.; SUAREZ, J.M.; MORAES, M.H. (1996) Condição hídrica e de porosidade de solos da Bacia do ribeirão Santo Anastácio (SP), São Paulo, Revista de Geografia da Unesp, vol.13: 111-125.

CARVALHO, W. A.; PANOSO, L. A.; FREIRE, O.; RENNÓ, C. D.; GODOY, M.C.T.F.; SUDO, H.; TEIXEIRA, S.R.; SUAREZ, J.M. (1997) Levantamento semidetalhado dos solos da Bacia do Rio Santo Anastácio, Presidente Prudente, Boletim Científico da Faculdade de Ciências e Tecnologia, $D^{\text {to }}$. de Ciências Ambientais, FCT/FUNDACTE, v. 2 - 490 p., mapa e legenda.

CEDERGREN, H. R. (1967) Seepage, Drainage and Flow Nets., New York, J. Wiley \& Sons. $147 \mathrm{p}$.

CETESB - Companhia de Tecnologia de Saneamento Básico (1986) Monitoramento da Qualidade das Áquas Subterrâneas em Áreas de Infiltracão de Efluentes de Indústrias Químicas - Relatório Final, São Paulo, CETESB, 69p.

- Companhia de Tecnologia de Saneamento Básico (1988) Guia de Coleta e Preservação de Amostras de Áqua , São Paulo, CETESB, 150p.

CHERRY, J. (1984) Groundwater contamination, in: FLEET, M. E. (ed) Short Course on Environmental Geochemistry, London/ON, Canada, Mineral Association of Canada, 10: $296-306$.

CONOVER (1980) Practical Non parammetric Statistics,. - Wiley Series in Probability and Mathematical Statistics, 2 ed, New York, John Wiley and Sons. 493p.

CUSTODIO, E.; LLAMAS, R. (1990) Hidrología Subterranea. Barcelona, Omega, 1990. 2365p.

DOMERGUE, F. L. ; VÉDY, J. C. (1992) Mobility of heavy metals in soil profiles. Intern. Journal. Environ. Anal. Chem., v. 46, p.13-23, Gordon and Breach Science Publishers S.A., United Kingdom.

DEPARTAMENTO DE ÁGUAS E ENERGIA ELÉTRICA - DAEE(1979) Estudo de Áquas Subterrâneas das Regiöes Administrativas 10 e 11: Presidente Prudente e Marilia. Săo Paulo, 3 v. 
EMBRAPA - EMPRESA BRASILEIRA DE PESQUISA AGROPECUÁRIA - SERVIÇO NACIONAL DE LEVANTAMENTO E CONSERVAÇĀO DE SOLOS (1988) Critérios para distinção de classes de solos e de fases de unidades de mapeamento. Rio de Janeiro, Documento da EMBRAPA, n. 11, 67p.

FERNANDES, L. A. (1992) A Cobertura Cretácea Suprabasáltica no Paraná e Pontal do Paranapanema (SP): Os Grupos Bauru e Caiuá. São Paulo, 127 p. (Dissertação Mestrado no Programa de Geologia Sedimentar) - Instituto de Geociências, Universidade de São Paulo.

FETTER, C. W. (1993) Contaminant Hydrogeology. New York, Macmillan. 456p.

(1994) Applied Hydrogeology. 3. ed., New York, Macmillan College.

$691 \mathrm{p}$.

FONTES,L.E.F.; OLIVEIRA, L. B. (1982) Disponibilidade de água de solos do Norte de Minas Gerais - Área de atuação da SUDENE, EMBRAPASNLCS, Rio de Janeiro, Boletim de Pesquisa no. 8, 22p.

FOWLER, W. B. ; LOPUSHINSKY, W. (1989) An economical, digital meter for gypsum soil moisture blocks, Soil Science Society American Journal, n. 53, p. 302-305.

FRANCISCO, F. C. (1989) Análise Ambiental e Consequências do Desmatamento no Município de Presidente Prudente no período de 1917 a 1986. Rio Claro/SP, - Instituto de Geociências e Ciências Exatas, Universidade Estadual Paulista, Tese (Mestrado em Geografia Física), 242p.

FREIRE, O.; GODOY, M.C.T. F.; CARVALHO, W. A. (1992) Erodibilidade de alguns solos do Oeste do Estado de São Paulo. Revista de Geografia da UNESP, n.11, p. 77-87.

FUNDAÇĀO IBGE - Instituto Brasileiro de Geografia e Estatística: (1997) Contagem da populacão 1996: Resultados relativos a sexo da população e situação domiciliar, Rio de Janeiro, Fundação IBGE, v.1, 720 p.

GODOY, M. C. T. F. (1989) Mapeamento Geotécnico Preliminar da Região Urbana de Presidente Prudente - Escala 1/25.000. São Carlos, 2v. (Dissertação - Mestrado em Geotecnia) - Escola de Engenharia de São Carlos, Universidade de São Paulo. GODOY, M. C. T. F. (1997) Estudo de viabilidade para a instalação de poço tubular destinado ao abastecimento de água para a Faculdade de Ciências e Tecnologia UNESP/PP, Presidente Prudente, agosto de 1997 -Comunicaçăo Interna, 18 p. 
GUYMON, G. L. (1994) Unsaturated Zone Hydrology. New Jersey, Prentice Hall. 209p.

HEM, J.D. (1985) Study and interpretation characteristics of natural water. U.S. Geological Survey Supply Paper, (1473): 1-269.

IPT - INSTITUTO DE PESQUISAS TECNOLÓGICAS DO ESTADO DE SÃO PAULO (1981a) Mapa Geológico do Estado de São Paulo. São Paulo, IPT. (Escala 1:500.000).

(1981b) Mapa Geomorfológico do Estado de São Paulo. São Paulo, IPT. (Escala 1:1.000.000).

JONES, R.J.A.; THOMASSON, A. J.(1990) Mapping potencial nitrate leaching losses from agricultural land in the UK, in: HAMER, P.J.C., LEEDS-HARRISON, P.B. (eds) Nitrates and Irrigation, Silsoe, p. 35-40

KOPPEN, W. (1948) Climatología, México, Fondo de Cultura Económica. 478 p.

LAGERSTEDT, E.; JACKS, G.; SEFE, F. (1994) Nitrate in grounwater and $\mathbf{N}$ circulation in Eastern Botswana. Environmental Geology, Springer Verlag, 23:60-

LANDIM, P.M.B. (1998) Análise Estatística de Dados Geológicos, São Paulo, FUNDACT/ Editora UNESP, $226 \mathrm{p}$.

LIBARDI, P.L. (1995) Dinâmica da Água no Solo, Piracicaba/SP, ESALQ. 497 p.

MARIÑO, M. A.; LUTHIN, J. A. (1982) Seepage and Groundwater, Elsevier.489 p.

MARQUES, R. M. (1998) Geopesquisa: apresentação, São Paulo - SP , GEOPESQUISA - Investigações Geológicas, 8 p.

MARTELAT, A.; ACKERER, P.; SCHENK, C. (1991) Spatial variability of water and nitrate migration in soil on a parcel scale Chemistry, Agriculture and the Environment, Cambridge, UK, Royal Society of Chemistry, 1991: 157-184.

MATTHESS, G. (1982) The Properties of Groundwater, New York, John Wiley \& Sons. $406 \mathrm{p}$.

MERCK \& CO (1983) The MERCK Index, Merck \& Co, Inc, $10^{\star}$. Ed., White House Station. NY.

METCALF, L.; EDDY, H.P. (1979) Wastewater Engineering: Treatment, Disposal, Reuse, 2a. Ed., McGraw Hill, New York. 296 p.

MONTEIRO, C.A.F. (1973) A dinâmica climática $\theta$ as chuvas no Estado de São Paulo: Estudo em forma de Atlas. São Paulo, USP/IGEOG, 1973. 
OWENS. L.B. (1990) Nitrate-Nitrogen concentrations in percolate from lysimeteres planted to a legume-grass mixture, Journal of Environmental Quality, 19: 131-135.

PERUSI, M. C.; TEIXEIRA, S. R.; GODOY, M. C. T. F. (1993) Identificação de argilominerais do Oeste do Estado de São Paulo. In: CONGRESSO DE INICIAÇÃO CIENTÍFICA DA UNESP, 2., Bauru, 1993 - Resumos.

POLI, D.C.R. (1989) Aplicacãa e Avaliação da Técnica de Marcacãa da Umidade do Solo com Trítio Artificial em Pesquisas Hidrogeológicas no Brasil, São Paulo, 178 p (Tese - Doutorado) Instituto de Pesquisas Energéticas e Nucleares, Universidade de São Paulo.

PORSANI, J. L. (1999) Ground Penetrating Radar (GPR) Proposta metodológica de emprego em estudos geológico-geotécnicos nas regeiões de Rio Claro e Descalvado - SP, Rio Claro, 145 p. (Tese - Doutorado) - Instituto de Geociências e Ciências Exatas, Universidade Estadual Paulista, UNESP.

QASIM, S.R. ; CHIANG, W. (1994) Sanitary Landfill Leachate Generation Control and Treatment, Lancaster, Technomic Publishing. $339 p$.

REICHARDT, K. (1988) Capacidade de campo, Revista Brasileira de Ciência do Solo, Campinas, 12: 211-216.

(1990) A Áqua em Sistemas Agrícolas, 1. ed., São Paulo, Manole. $188 p$.

(1996) Dinâmica da Matéria e da Energia em Ecossistemas, 2. ed.,

Piracicaba, USP/ESALQ, Dto. Física e Meteorologia. 513p.

ROBERTSON, W.D.; SUDICKI, E.A.; CHERRY, J. A.; RAPAPORT, R.A.;SHIMP, R.J. (1989) Impact of a domestic septic system on an unconfined sand aquifer, in: KOBUS ; KINZELBACH (eds), Contaminant Transport in Groundwater, 105-112.

RUPRECHT, J. K. ; SCHOFIELD, (1990) Seasonal soil water dynamics in the Jarrah Forest, Western Australia, 1: Results from a hillstope transect vith coarse-textured soil profiles. Hydrological Processes, John Wiley \& Sons, n. 4, p. 241-58.

SALOMĀO, F. X. T. (1994) Processos erosivos lineares em Bauru (SP): Regionalizacão cartográfica aplicada ao controle. São Paulo, 2 v. (Tese-Doutorado) - Faculdade de Filosofia, Letras e Ciências Humanas da Universidade de São Paulo.

SANT'ANNA NETO, J.L.; BARRIOS, N.A.Z.(1992) Variabilidade e tendência das chuvas na regiăo de Presidente Prudente. Revista de Geografia da UNESP, n. 11, p.6376. 
SATRIYO, B.; BLAIR, A.W.; SAMANI, Z. (1990) Calibration of tensiometers and gypsum blocks using soil moisture content, In: IRRIGATION AND DRAINAGE NATIONAL CONFERENCE, 1990, Anais., New York, p. 552-8, ASCE - Irrigation \& Drainage Division.

SUDO, H. (1980) Bacia do Alto Santo Anastácio: Estudo geomorfológico. São Paulo, 235 p. (Tese - Doutorado) - Faculdade de Filosofia, Letras e Ciências Humanas da Universidade de São Paulo.

SUGUIO, K. (1980) Rochas Sedimentares: propriedades, gênese, importância econômica, São Paulo, Edgard Blücher Ltda. 500p.

SZIKSZAY, M.; CONSONI, A. J.; GUIGUER, N.; HASSUDA, S.; KIMMELMANN, A.A.; SGAMBATO, F.; YOSHINAGA, S. (1986) Instalação de uma estação experimental para o estudo da dinâmica e da evolução da composição da água na zona não saturada, Revista Águas Subterrâneas, n. 10, p. 5-20.

SZIKSZAY, M.; KIMMELMANN E SILVA, A. A. ; HYPÓLITO, R. (1989) Estudo hidrogeoquímico das zonas não-saturada e saturada em terrenos subtropicais úmidos. In: CONGRESSO BRASILEIRO DE GEOQUIMICA，2., Anais. p.329-37.

TOLLNER, E. W. ; MOSS, R. B. (1985) Neutron probe vs. tensiometers vs. moisture for monitoring soil moisture status, Suplemento ASCE, 19 p.l Apresentado a WINTER MEETING -ASCE, Chicago, 1992.

TUBELIS, A.; NASCIMENTO, F.J.L. (1979) Meteorologia Descritiva. Livraria Nobel S.A., São Paulo. 374p.

VARGAS, M. (1977) Introducão à Mecânica dos Solos, São Paulo, Mcgraw-Hill do Brasil - Universidade de São Paulo. 509 p.

VEENIS, Y.M.M.; BLEUTEN, W. (1989) The use of saturated column-experiments in the asessment of pollutant transport in aquifers, in: KOBUS ; BALKEMA (eds) Contaminant Transport in GrounWater, Rotterdam, p 141-145.

VIEIRA, L. S. (1988) Manual da Ciência do Solo: com ênfase em solos tropicais., 2. ed., São Paulo, Ceres. 463p.

VOGEL, A. I. (1982) Química Analítica Quantitativa - Teoria y práctica, tradução para o espanhol de Miguel Catalano, Buenos Aires, Kaplusz. 2 vol.

WAGENET, R.J.; BIGGAR, J.W.; NIELSEN, D.R. (1977) Tracing the transformation of urea fertilizer during leaching, Soil Sci. Soc. American Journal, vol.41: 896-905. 
WISCHMEIER, W.H.; JOHNSON, C. B. ; DROSS, B.V. (1971) A soil erodibiltily nomografh for farmland and construction sites. Journal of Soil and Water Conservation, $v$. 26, n. 5, p.189-93.

ZUQUETTE, L.V.; GANDOLFI, N. (1987) Mapeamento geotécnico aplicável a rejeitos sépticos. In: CONGRESSO BRASILEIRO DE GEOLOGIA DE ENGENHARIA, 5, São Paulo, 1987. Anais., São Paulo, ABGE, v. 2, p.313-22. 